UNIVERSIDADE DE SÃO PAULO

FACULDADE DE FILOSOFIA, LETRAS E CIÊNCIAS HUMANAS

DEPARTAMENTO DE FILOSOFIA

PROGRAMA DE PÓS-GRADUAÇÃO EM FILOSOFIA

Filosofia moral no mundo do pós-guerra:

Estudo sobre Adorno

Felipe Catalani

São Paulo

2019 


\title{
Felipe Catalani
}

\section{Filosofia moral no mundo do pós-guerra:}

\section{Estudo sobre Adorno}

Dissertação apresentada ao Programa de PósGraduação em Filosofia do Departamento de Filosofia da Faculdade de Filosofia, Letras e Ciências Humanas da Universidade de São Paulo, para obtenção do título de Mestre em Filosofia sob a orientação do Prof. Dr. Vladimir Pinheiro Safatle.

\section{Versão corrigida}

\author{
São Paulo
}

2019 
Autorizo a reprodução e divulgação total ou parcial deste trabalho, por qualquer meio convencional ou eletrônico, para fins de estudo e pesquisa, desde que citada a fonte.

Catalogação na Publicação

Serviço de Biblioteca e Documentação

Faculdade de Filosofia, Letras e Ciências Humanas da Universidade de São Paulo

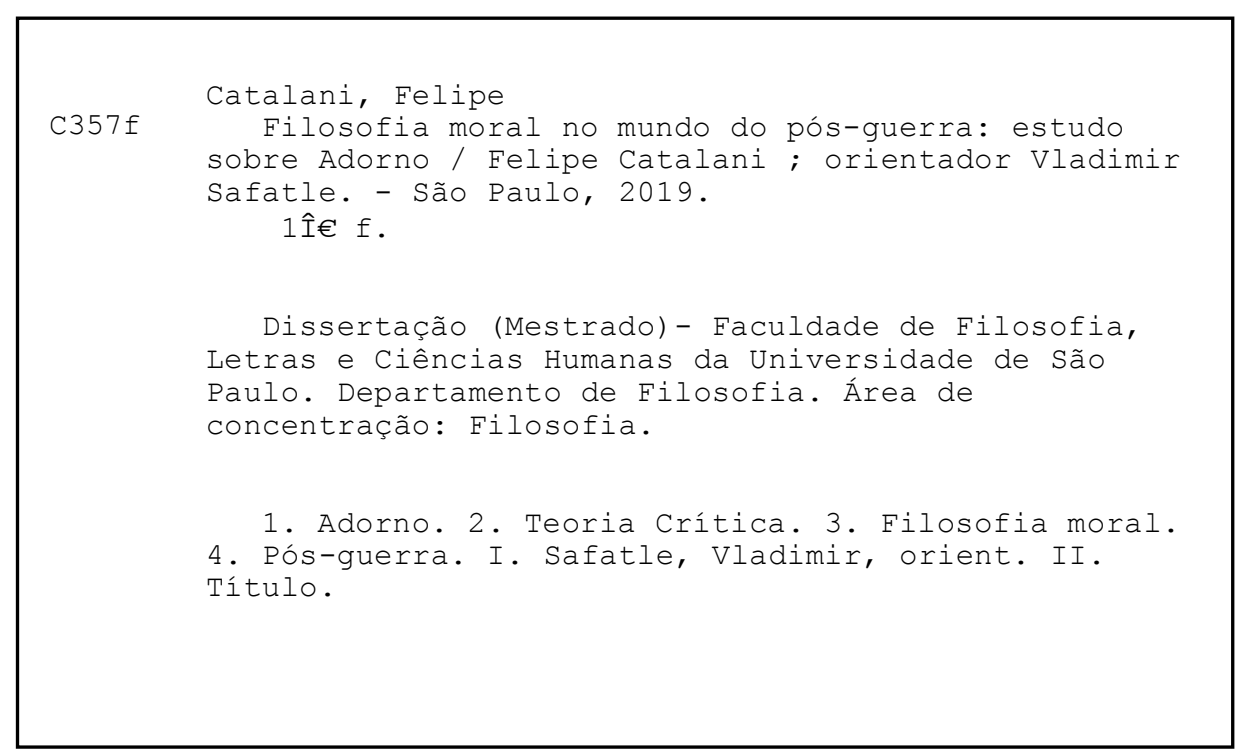

O presente trabalho foi realizado com auxílio financeiro da FAPESP-Capes (processo: 2016/06614-9) 


\title{
ENTREGA DO EXEMPLAR CORRIGIDO DA DISSERTAÇÃO/TESE
}

\section{Termo de Ciência e Concordância do (a) orientador (a)}

\author{
Nome do (a) aluno (a): Felipe Catalani
}

Data da defesa: 28/02/2019

Nome do Prof. (a) orientador (a): Vladimir Pinheiro Safatle

Nos termos da legislação vigente, declaro ESTAR CIENTE do conteúdo deste EXEMPLAR CORRIGIDO elaborado em atenção às sugestões dos membros da comissão Julgadora na sessão de defesa do trabalho, manifestando-me plenamente favorável ao seu encaminhamento e publicação no Portal Digital de Teses da USP.

São Paulo, 30/09/2019

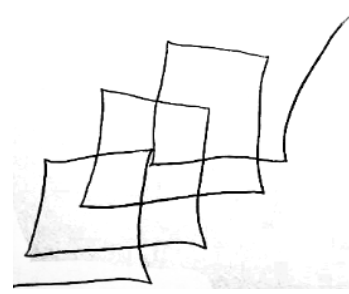

(Assinatura do (a) orientador (a) 
CATALANI, Felipe. Filosofia moral no mundo do pós-guerra: estudo sobre Adorno.

Dissertação (Mestrado) apresentada à Faculdade de Filosofia, Letras e Ciências Humanas da Universidade de São Paulo para obtenção do título de Mestre em Filosofia.

Aprovado em:

Banca Examinadora

Prof. Dr. Instituição

Julgamento Assinatura

Prof. Dr. Instituição

Julgamento Assinatura

Prof. Dr. Instituição Julgamento Assinatura

Prof. Dr. Instituição

Julgamento Assinatura 


\section{Agradecimentos}

Ao professor Vladimir Safatle, que orientou este trabalho, que é um desdobramento de algo que começou como um projeto de iniciação científica já em 2011. Com o tempo, percebe-se retrospectivamente o quanto há de debate acumulado: um debate vivo que é um contínuo espaço de formação. Aos professores Jorge de Almeida e Paulo Arantes, pelas recomendações decisivas no exame de qualificação. À professora Rahel Jaeggi, por ter me recebido na Humboldt-Universität para um estágio de pesquisa em 2018.

Ao amigo Daniel Garroux, que fez uma revisão detalhada do texto de qualificação, e com quem sempre aprendo (desde os anos de graduação) a desfazer vícios de estilo.

A Michael Schwarz, do Theodor W. Adorno-Archiv, pela ajuda no acesso aos materiais de arquivo, que foram cruciais para a redação dessa dissertação.

Fundamentais foram (e são) as constantes conversas com os amigos, em que se embaralham as questões teóricas e os anseios políticos. As pausas para o café com a Yasmin e as caminhadas com o Luiz e Giovanni foram inspiradoras, assim como todos os encontros da boemia adorniana brasileira: Bruno, Amaro, Daniel, Carine, Mariana, Francisco, Francielle. As discussões sobre a Minima Moralia e sobre Sartre que seguiam pela madrugada adentro com Silvia, Fernando, Raquel, Paulo, Mateus, Bruno, Priscila, Gustavo, Eduardo e Silvio também marcaram a redação desse texto, assim como os debates das noites de quarta, fermento para a imaginação política.

Agradeço também às leituras entusiasmadas e às críticas que recebi, quando apresentei alguns dos capítulos dessa dissertação nas reuniões de sexta do grupo de orientandos. Às secretárias do departamento de filosofia: Luciana, Geni, Marie, Susan.

Aos amigos de casas e de vida, por todas as partilhas: Nina, Gabi, Caetano, Arthur L. Artur R., Danilo, Ariel, Larissa. Aos de longa data, que continuam juntos: Arthur Z., Bia, Bianca, Marina, Miguel, Pedro A. Ao Fábio, velho camarada, que há uma década atrás me apresentou o terrível mundo do negativo. Aos amigos berlinenses, pelos encontros e reencontros: Michael, Richard, Johanna, Laura, Jorge, Lia, Timm.

À Ana Paula, pela interpretação dos sonhos.

Aos meus pais, pelo carinho e apoio, com quem aprendi o espírito da investigação.

À Fernanda, cuja poesia do coração resiste à prosa do mundo - por todo o afeto e companheirismo. 


\section{RESUMO}

CATALANI, Felipe. Filosofia moral no mundo do pós-guerra: estudo sobre Adorno. 2019. 100 f. Dissertação (Mestrado) - Faculdade de Filosofia, Letras e Ciências Humanas, Universidade de São Paulo, São Paulo, 2019.

No cerne desta dissertação está uma investigação sobre os sentidos da reflexão moral na obra de Theodor W. Adorno em uma articulação com sua dimensão política, a crítica da sociedade e a interpretação sobre o decurso histórico. O texto divide-se em três capítulos: o primeiro trata do diagnóstico de época do qual partimos, a saber, o mundo tal como ele se configurou após a Segunda Guerra Mundial. O segundo capítulo explora a dimensão “prática” - ética e política imanente ao conceito de verdade na tradição da teoria crítica, de modo a considerar a relação entre moral e conhecimento. O terceiro capítulo, intitulado "Antinomias da moral”, disserta sobre a abordagem adorniana de problemas tradicionalmente vinculados à filosofia moral, sobretudo a partir de uma interpretação da Minima Moralia, da Dialética Negativa e de seus cursos dedicados ao tema.

Palavras-chave: Adorno; teoria crítica; filosofia moral; pós-guerra. 


\begin{abstract}
CATALANI, Felipe. Moral philosophy in the postwar world: studies on Adorno. 2019. 104 f. Dissertação (Mestrado) - Faculdade de Filosofia, Letras e Ciências Humanas, Universidade de São Paulo, São Paulo, 2019.

The core of this dissertation is an investigation on the meaning of Theodor W. Adorno's moral reflections, in an articulation with its political dimension, the critique of society and an interpretation of the historical process. The text contains three chapters: the first one deals with the diagnosis of time of the post-war world. The second chapter explores the "practical" ethical and political - dimension which is immanent to the truth concept employed in the tradition of critical theory, so that we can consider the relations between moral and knowledge. The third chapter, entitled "Antinomies of morals", discusses Adorno's approach of traditional problems of moral philosophy, based mostly on an interpretation of his works Minima Moralia and Negative Dialectics, and his lectures.
\end{abstract}

Key-words: Adorno; Critical Theory; moral philosophy; post-war. 


\section{Sumário}

Apresentação

$\begin{array}{lr}\text { Capítulo } 1 \text { - O mundo do pós-guerra } & 12\end{array}$

Uma certa normalidade 12

Passado presente: saída de guerra e reconstrução $\quad \square 14$

Um mundo estável: Welfare, regulação do antagonismo e a "fórmula da paz"

Capitalismo perpétuo e crise imanente

A bomba, os russos e os americanos

A latência e o manifesto: o "leninismo" de Adorno

Capítulo 2 - Dimensão prático-moral do conceito enfático de verdade $\quad[51$

$O$ mundo é falso: imaginação e verdade $\quad \square 51$

$\begin{array}{ll}\text { Verdade como arma } & \square 60\end{array}$

Bilderverbot: verdade negativa. $\quad \square 64$

De volta aos fatos: Habermas e a correção $\quad \square 67$

Exagerar é preciso: verdade e linguagem $\quad \square 74$

"O todo é o não-verdadeiro"

Cerne temporal da verdade $\quad \square 91$

Contradição verdadeira: o conceito hegeliano de verdade $\square 96$

$\begin{array}{ll}\text { Capítulo } 3 \text { - Antinomias da moral } & 101\end{array}$

$\begin{array}{ll}\text { Origens da dialética entre moral e política } & 101\end{array}$

Uma espécie de dignidade da vida privada $\quad \square 106$

$\begin{array}{ll}\text { Declinio da eticidade } & \square 108\end{array}$

A lei do coração e o curso do mundo: protesto moral e utopia 112

A liberdade: altos e baixos da atualidade de Kant 118

Resistência (Sartre: pro e contra) 123

$\begin{array}{ll}\text { Justificar seria obsceno: sobre o horror } & 127\end{array}$

Intelectualismo moral e desconforto 134

Seriedade, silêncio, vergonha 139

Fome: valor de uso e sofrimento 152

Compaixão, calor, frieza 161

$\begin{array}{ll}\text { Bibliografia } & 172\end{array}$ 


\section{Apresentação}

"Filosofia moral é uma tautologia estúpida", escreveu Walter Benjamin em um de seus fragmentos. ${ }^{1}$ Tampouco Adorno se refere à "filosofia moral" como um "gênero" filosófico delimitado e apartado - ele emprega o termo somente por razões escolares, por exemplo em seus cursos ministrados em Frankfurt, aos quais ele deu o título de "Problemas de filosofia moral", e que só postumamente foram publicados. Rüdiger Bubner defendia que a Teoria Estética de Adorno não era tanto uma teoria sobre a estética, mas, para ele, o adjetivo "estética" poderia ser pensado como um predicado da própria teoria, ou seja, a teoria tornava-se estética. ${ }^{2}$ Talvez seja possível pensar de forma análoga sobre a ideia de "fillosofia moral", a ponto de o termo se tornar, efetivamente, como diz Benjamin, uma "tautologia estúpida". Tal consideração significa uma rejeição ao campo consolidado da "filosofia moral" e ao mesmo tempo coloca a moral no centro da ideia mesma de filosofia.

Pode-se dizer então que, para aquilo que convecionou-se chamar de "teoria crítica", a ideia de uma filosofia moral, enquanto disciplina autônoma, não faz sentido. Ao mesmo tempo, os problemas assim ditos "morais" estão no cerne dessa mesma teoria crítica, a ponto de, como diz Jay Bernstein, o leitor perceber uma "intensidade ética" em tudo que Adorno escreveu. Um dos intuitos desse trabalho é tentar tornar explícitas tais questões subjacentes, decifrar a problemática moral, sem no entanto transformar tais problemas em uma definição rígida dos "pressupostos normativos" da teoria ou em uma discussão preponderantemente metodológica, que tenta se livrar dos objetos e das determinações particulares em um eterno prolegômenos para toda teoria crítica futura. ${ }^{3}$ Buscamos antes investigar a experiência histórica sedimentada na reflexão moral, que se revela, em Adorno, instância privilegiada para a compreensão tanto da objetividade social quanto dos impasses políticos de época.

Há, portanto, uma tensão nessa dissertação: por um lado, ela é explicação de texto e se insere no gênero história da filosofia (no caso, história da teoria crítica), e, por outro lado, ela busca ser teoria crítica (de modo que ela deve ser, ao mesmo tempo, explicação

\footnotetext{
${ }^{1}$ Walter Benjamin, WBGS6, p. 93.

${ }^{2}$ R. Bubner, "Kann Theorie ästhetisch werden?" in Materialien zur ästhetischen Theorie Adornos.

3 Rahel Jaeggi afirmou recentemente, em tom de autocrítica: nós elaboramos todos os instrumentos conceituais para fazer uma crítica da sociedade, caso um dia nós queiramos fazer essa crítica.
} 
de mundo). A questão é: como unir teoria crítica e história da teoria crítica, ou como fazer história da filosofia no espírito do "materialismo interdisciplinar" (Horkheimer)? O resultado dessa tentativa (levando a sério o termo "história" em "história da filosofia") é a sobreposição de duas abordagens: uma mais conceitual e teórica, que mergulha no movimento interno do pensamento dos autores analisados, e outra histórica, mais distanciada em relação aos textos, porém mais sensível às contingências dos acontecimentos e das transformações, e que mira os fenômenos do mundo social, tentando capturar a "essência" (para usar uma linguagem hegeliana) da sociedade e do curso das coisas. Dito de outro modo, é uma tentativa de unir um diagnóstico de época (no caso, sobre o mundo europeu do pós-guerra), uma reflexão sobre o decurso histórico e uma crítica das categorias fundamentais do capitalismo a partir de Marx.

A fim de investigar o vínculo entre pensamento teórico e moral, dedicamos um dos capítulos (o segundo) à dimensão ético-prática do conceito de verdade na teoria crítica a partir de uma discussão com diversos autores da tradição frankfurtiana. As questões que podem ser consideradas como mais tradicionalmente vinculadas à moral (em tensão com a política) foram dicutidas no terceiro capítulo. A ideia de pensar o "mundo do pós-guerra" (ao qual é dedicado o primeiro capítulo) foi uma tentativa não tanto de desenhar um "contexto" a partir do qual seriam deduzidos, de forma externa, os problemas teóricos, mas antes de trazer os movimentos da história para o núcleo desses problemas. Com isso, buscamos fazer justiça a um lado um pouco esquecido da ideia de teoria crítica, que deveria ser uma "teoria do decurso histórico" (Theorie des geschichtlichen Verlaufs), como escreveu Horkheimer no prefácio à Zeitschrift für Sozialforschung, relembrado por Leo Löwenthal como um aspecto central daquilo que os velhos frankfurtianos buscavam. ${ }^{4}$ Essa seria a tarefa contraditória de pensar, ao mesmo tempo, as mudanças de época e a maldição do "eterno retorno do mesmo", desse "sempreigual" do capitalismo, que é, por excelência, o objeto sobre (e contra) o qual a teoria crítica dedicou seus esforços.

\footnotetext{
${ }^{4}$ Leo Löwenthal, Mitmachen wollte ich nie: ein autobiographisches Gespräch mit Helmut Dubiel, p. 92.
} 


\section{Capítulo 1 - O mundo do pós-guerra}

On passe de la paix à la guerre, en notre siècle, par un jeu continu de dégradés. Il va falloir, dans l'hypothèse la plus optimiste, refaire ce chemin en sens inverse. Aujourd'hui, 20 août 45, dans ce Paris désert et affamé, la guerre a pris fin, la Paix n'a pas commencé.

Jean-Paul Sartre, La fin de la guerre

\section{Uma certa normalidade}

“Cuba 1962”: esse é o tema da edição de 2012 da revista alemã Idee: Zeitschrift für Ideengeschichte. Na capa, uma Marilyn Monroe radiante, rindo, com os braços estendidos para cima. $\mathrm{O}$ descompasso entre a felicidade representada pelo símbolo maior da indústria cultural e a data em que o mundo esteve mais próximo de seu fim literal durante aqueles treze dias do mês de outubro de 1962 é uma imagem precisa do que estamos chamando aqui de "mundo do pós-guerra". Os dois elementos são necessários para compreendê-lo: por um lado, ostenta-se uma aparente felicidade, ora calma, ora eufórica, e por outro, um potencial explosivo invisível de uma civilização que havia acabado de se destruir e que se desenvolvia sob o equilíbrio geopolítico da Guerra Fria, que por vezes esquentava nas periferias do mundo, e que virtualmente estava prestes a transformar o planeta em uma rocha inabitada. Porém, essa época era, ao mesmo tempo, "uma era feliz", que chegou a ser celebrada como apoteose da modernização e, portanto, como uma era de progresso (que se mantém ainda na visão de muitos como a régua que mede a atual "grande regressão"). O mundo do pós-guerra é caracterizado por um violento recalque daquilo que o constituiu, a saber, a Guerra em sua dimensão que o século $\mathrm{XX}$ predicou como mundial. Um crítico literário que foi buscar no mundo pós-1945 a “origem do presente" notou que, apesar de tudo,

a sensação de destruição irreversível - cuja presença foi tão forte nos anos que imediatamente seguiram a guerra (e não apenas nos países onde ela ocorreu) - desapareceu de modo súbito; para ser mais preciso, é como se o evento não tivesse deixado sinais comparáveis aos que marcaram o mundo depois de 1918. Olhar a edição da Life de 24 de dezembro de 1945 me faz pensar que o Natal desse ano deve ter sido já o momento em que foram neutralizados os efeitos da destruição, pelo menos nos Estados

5 Tim B. Müller, "Innenansichten des Kalten Krieges. Über ein glückliches Zeitalter" In Zeitschrift für Ideengeschichte 6, 2012 
Unidos. Página após página, a revista está repleta de palavras e imagens que anunciam como o mundo está voltando àquilo que sempre deveria ter sido. ${ }^{6}$

Nessa realidade nova e pacificada, há, segundo Gumbrecht, uma tensão não identificada: "Algo como uma disposição para um nervosismo violento perpassa a calma aparente desse mundo do pós-guerra, que aponta para um estado de coisas latente."7 A leitura impressionista do crítico deixa entrever um "sentimento do mundo" que parece ser preciso em seu caráter retrospectivo:

[...] quando folheio essas revistas do pós-guerra, muito assumidamente pacíficas e ordeiras, surpreende-me a violência recorrente na publicidade - acontece, por exemplo, na foto da erupção vulcânica feita com a câmera Graflex ${ }^{8}$. De um modo semelhante, a qualidade das lâminas de barbear é anunciada com imagens que mostram como são suaves ao passar sobre a pele macia do rosto de um bebê. Alguns quadrinhos representam a vida de casado, com piadas sobre maridos que espancam as esposas porque o café não está forte o suficiente, ou porque ela se esqueceu de acordar o trabalhador da família a tempo de ele ir ao emprego. Parece haver também uma obsessão com velhos que se agitam doentes e que necessitam com urgência de determinada marca de medicamentos. ${ }^{9}$

A normalidade por vir era uma normalidade nervosa. Em 1945, Sartre testemunha do lado francês, com o fim da ocupação alemã, um sentimento que indicava uma continuidade da vida, que, mesmo durante a guerra, era cotidiana $^{10}$. Essa vida depois da “guerra que não finda de findar" era ainda a mesma:

Nada havia mudado na vida cotidiana. Os zumbidos do rádio, as letras em negrito dos jornais não conseguiam nos persuadir. Era como se desejássemos algum prodígio, um signo no céu para nos provar que a paz estava inscrita nas coisas. ${ }^{11}$

\footnotetext{
${ }^{6}$ Hans Ulrich Gumbrecht, Depois de 1945: latência como origem do presente, p. 37.

${ }^{7}$ Idem, p. 41.

${ }^{8}$ Que trazia a lembrança do cogumelo de fumaça da detonação das bombas em Hiroshima e Nagasaki [FC].

${ }^{9}$ Hans Ulrich Gumbrecht, Depois de 1945: latência como origem do presente, p. 41

10 "Mas não se deve esquecer que a ocupação foi cotidiana. Alguém, a quem perguntávamos o que ele havia feito sob o Terror, respondera: 'eu vivi...' É uma resposta que hoje poderíamos todos fazer." Sartre, "Paris sous l'occupation", in Situations III, Lendemains de guerre p. 18.

${ }^{11}$ Jean-Paul Sartre, "La fin de la guerre" in Situations III, Lendemains de guerre, p. 63.
} 


\section{Passado presente: saída de guerra e reconstrução}

A "estranha presença de um passado que não tinha desaparecido", 12 que parecia já ter sido enterrado e não ter mais impacto na vida das pessoas, Gumbrecht chamou de "latência", portanto, algo não manifesto. O "pós-guerra" era considerado encerrado em 1948, quando terminava o período de fome e inflação dos três anos após 1945. Entretanto, havia algo desse tempo formado pela saída de uma situação de guerra que perdurava (lembremos que o primeiro "pós-guerra" havia sido o tempo após a "Grande Guerra”, a saber, a primeira ${ }^{13}$ ). O esquecimento dos acontecimentos recentes transforma a elaboração de um passado que é ainda contemporâneo em uma tarefa moral - e coincide, como mostra o historiador Henri Rousso, com o surgimento da contemporaneidade como objeto de estudo histórico - o que conflitava com a tradicional distância temporal necessária para a frieza e o desinteresse em relação ao objeto, e, portanto, para a autoafirmação da história enquanto ciência. Paralelamente ao veloz esquecimento dos eventos catastróficos de anteontem na "paz" eufórica do boom fordista e da expansão do consumo (embora se trate, como diz Marcuse, de uma paz garantida pela ameaça ininterrupta de guerra $^{14}$ ), aparece a "testemunha moral", a figura do "sobrevivente que fala em nome dos camaradas mortos, e que conduz uma forma de relação com o passado marcada pela obrigação da lembrança e pela rejeição do esquecimento." ${ }^{15}$ As catástrofes recentes da guerra inauguram uma relação com o passado que se expressa na disciplina da "história contemporânea", que se debruça sobre um passado que permanece presente e que carece de elaboração e memória:

Salta aos olhos constatar que a Grande Guerra fez surgir ou ressurgir a um só tempo no espaço público a figura do historiador do tempo presente, somado pela circunstância de dar sentido à catástrofe ocorrida, e aquela do testemunho, que busca por outras vias e outros suportes as palavras para dizê-la. [...] Em toda parte, ao menos nos territórios tocados pela guerra, a história da última catástrofe em data - que é também a primeira do gênero - ocupa então um lugar considerável no campo social. ${ }^{16}$

\footnotetext{
${ }^{12}$ Hans Ulrich Gumbrecht, Depois de 1945, p. 39.

13 "A Primeira Guerra fez surgir as primeiras formas de memória 'negativa' que repousam sobre a perpetuação do luto e a assombração [hantise] de uma repetição do passado". Henri Rousso, $L a$ dernière catastrophe: l'histoire, le présent, le contemporain, p. 101.

${ }^{14}$ Herbert Marcuse, One-Dimensional Man, p. xl.

${ }^{15}$ Henri Rousso, La dernière catastrophe: l'histoire, le présent, le contemporain, p. 97

${ }^{16}$ Henri Rousso, La dernière catastrophe: l'histoire, le présent, le contemporain, p. 99.
} 
Manter presente o passado (que efetivamente assombra o presente sem que sua dimensão assombrosa seja sentida) torna-se dever moral - não é por outro motivo que Adorno diz que "a memória é uma qualidade moral" e que o esquecimento é uma "categoria altamente burguesa"17. A normalidade era fundada no esquecimento e no recalque, ao mesmo tempo em que o "retorno caduco à normalidade"18 (como Habermas caracterizou os anos 1950 na Alemanha) era também dependente desse trabalho público de memória e da reparação, que produz um novo vínculo entre política, justiça e tempo ${ }^{19}$. Em suma, lembrar para poder esquecer. Em diversos países europeus (e também fora da Europa) começam a aparecer institutos de pesquisa dedicados ao estudo do passado recente. Na Dialética Negativa, antes de começar a contenda conceitual contra a ontologia, Adorno lembra na primeira frase do capítulo sobre Heidegger que as "ontologias na Alemanha, sobretudo a ontologia heideggeriana, continuam exercendo influência, sem que os rastros do passado político provoquem qualquer horror."20 Compreende-se que a normalidade do pós-guerra teve seus alicerces na perda da capacidade de se horrorizar. O debate em torno da "culpa coletiva" ${ }^{21}$ era carregado de tentativas de amenização e de negacionismo em uma Alemanha que depois da guerra continuava encharcada de nazismo, seja ideologicamente, seja literalmente, por exemplo, na participação massiva no governo Adenauer de pessoas que estavam ativamente

\footnotetext{
${ }^{17}$ Adorno, "Graecullus", Frankfurter Adorno Blätter VIII, p. 33.

${ }^{18}$ Habermas, "A descontaminação do passado" in A nova obscuridade, p. 366. Em outro texto, Habermas fala sobre o "clima restaurativo" e o "cultivo da perda de memória nacional": "Kultivierung des nationalen Gedächtnisverlustes ist ein restauratives Klima ohne echtes Geschichtsbewußtsein, eine Stabilisierung der Unentschiedenheit zwischen gestern und morgen, in der sich das politische Interim spiegelt, ohne den Mut, sich seine Vorläufigkeit einzugestehen und sich über sich selbst klarzuwerden." Habermas, Philosophisch-politische Profile. Frankfurt am Main: Suhrkamp, 1984, p. 129.

19 Seria interessante pensar como aqui já começamos a entrar em um novo "regime de historicidade" (segundo o termo de François Hartog, e que Paulo Arantes chamou de "novo tempo do mundo"), em que há um condensamento da experiência temporal no presente. Análogo ao encurtamento do "horizonte de expectativa" e à perda de relevância do futuro para a experiência da história (o que significa uma alteração radical em relação à experiência temporal moderna tal como ela foi forjada na Revolução Francesa, a saber, uma temporalidade orientada para o futuro), é esse colamento do passado no presente, em que os crimes do passado, julgados no presente, se destemporalizam.

${ }^{20}$ DN, p. 59.

${ }^{21}$ Se no início incutir o sentimento de culpa coletiva fazia parte de uma iniciativa dos aliados, depois ela passa a retórica de amenização: "a tese da culpa coletiva serviu de meada inofensiva. [...] Ninguém hoje continua a manter em pé a afirmação da culpa coletiva." Jürgen Habermas, "A descontaminação do passado", p. 369
} 
presentes na administração hitlerista. "Esquecimento e fria enganação é o clima espiritual que melhor caracteriza a herança dos nazistas", escreve Adorno a Horkheimer em carta. ${ }^{22}$ O passado torna-se um problema a ser resolvido. ${ }^{23}$ Ou como diz Adorno em uma conferência de 1959 intitulada Was bedeutet: Aufarbeitung der Vergangenheit [O que significa: elaborar o passado], o passado é algo cujas causas persistem no presente. Superá-lo e elaborá-lo [aufarbeiten] significaria eliminar tais causas, que assombram o presente como um feitiço [Bann]. ${ }^{24} \mathrm{O}$ passado enquanto algo presente significa não poder dar às costas ao passado: "nós colocamos o passado em um lugar que em princípio não é o seu, a saber, diante de nós." ${ }^{25}$ A nova realidade é vivida como realidade traumatizada, cujas feridas mal cicatrizadas estão sempre prestes a serem reabertas. A palavra alemã Vergangenheitsbewältigung (superação do passado [! ${ }^{26}$ ) torna-se um conceito-chave em toda a Europa.

\begin{abstract}
A história não se enuncia mais de antemão sob a forma de tradições a respeitar, de heranças a transmitir, de conhecimentos a elaborar ou de mortos a comemorar, mas antes de problemas a "gerir", de um constante "trabalho" de luto ou de memória a ser levado a cabo, tanto é enraizada a ideia de que o passado deve ser arrancado do limbo do esquecimento, e que somente os dispositivos públicos ou privados vão permitir exumá-lo. O passado se tornou assim uma matéria sobre a qual se pode, ou mesmo se deve constantemente agir para adaptá-lo às necessidades do presente. ${ }^{27}$
\end{abstract}

A constituição da vida normal na RFA (que estava agora sob tutela norteamericana) depende deste trabalho de elaboração, desta Vergangenheitsbewältigung, sobretudo para tornar o presente alemão democratizado distinto daquele passado

\footnotetext{
${ }^{22}$ Carta a Horkheimer, apud Müller-Doohm, Adorno, eine Biographie, p. 499. Vale lembrar que, em 1949, Carl Schmitt publica um texto intitulado "A anistia ou a força do esquecimento". Tal permanência do passado nazista na Alemanha do pós-guerra será, aliás, uma questão maior no 1968 alemão.

${ }^{23}$ Henri Rousso, La dernière catastrophe: l'histoire, le présent, le contemporain, p. 24-25.

24 "O passado seria elaborado somente quando as causas do que ocorreu [des Vergangenen] fossem eliminadas. Somente porque as causas persistem, seu feitiço não foi quebrado até hoje." Adorno, "Was bedeutet: Aufarbeitung der Vergangenheit"

${ }^{25}$ Henri Rousso, La dernière catastrophe: l'histoire, le présent, le contemporain

${ }^{26}$ Notemos que "superação" aqui não é nada próximo da Aufhebung hegeliana, mas Bewältigung significa antes algo como superar no sentido de "lidar com algo difícil, penoso", por exemplo no sentido de lidar com "stress" ou com uma doença crônica, ou mesmo no sentido de superar um trauma. A não superação aparece como subtítulo de um livro crucial de Jean Améry: "Bewältigungsversuche eines Überwältigten", que significa, traduzido ao pé da letra, algo como "tentativas de superação de um vencido".

${ }^{27}$ Henri Rousso, La dernière catastrophe: l'histoire, le présent, le contemporain, p. 24-25.
} 
dominado pelos horrores do antissemitismo. A formação da Alemanha contemporânea (forjada na Reconstrução) é radicalmente fundada na presentificação do passado, mas com a finalidade de enterrá-lo (com um monumento em cima, por certo). ${ }^{28}$ A manutenção jurídica do passado (seja por meio da política de reparações, seja por outras vias) é fundamental para a normalidade social do presente. No jargão técnico: "Vergangenheitsbewältigung pressupõe, em primeiro lugar, um crime, em segundo lugar, o seu término, em terceiro lugar, uma democratização. Somente quando existem esses três aspectos pode ocorrer uma Vergangenheitsbewältigung que merece esse nome." ${ }^{29} \mathrm{Ou}$ seja, quando Adorno tenta dar sua própria interpretação do que seria uma Aufarbeitung der Vergangenheit (que no discurso público é sinônimo de Vergangenheitsbewältigung), trata-se ao mesmo tempo de apontar o caráter ideológico do discurso da “elaboração/superação do passado":

Deseja-se libertar do passado: justificadamente, pois não é possível viver à sua sombra e o terror não tem fim quando culpa e violência precisam ser pagas com culpa e violência; e injustificadamente, porque o passado de que se quer escapar ainda permanece muito vivo. O nazismo sobrevive, e continuamos sem saber se apenas como fantasma daquilo que foi tão monstruoso a ponto de não sucumbir à própria morte, ou se a disposição para o indizível continua presente nos homens bem como nas condições que os cercam. Não quero entrar na discussão a respeito das organizações neonazistas. Considero a sobrevivência do nacional-socialismo na democracia como potencialmente mais

\footnotetext{
28 "A discussão em torno da ditadura nazista pertence hoje de forma inconteste ao cerne da identidade nacional da Alemanha." Brandt Peter, "Die Auseinandersetzung Deutschlands mit dem Nationalsozialismus nach 1945", Disponível em: https://www.globkult.de/geschichte/zeitgeschichte/479-die-auseinandersetzung-deutschlandsmit-dem-nationalsozialismus-nach-1945 (Acesso: 5/12/2018). Assim começa uma palestra de 2005 de um professor alemão de história em uma das filiais do Goethe Institut - aliás, uma instituição fundada em 1951 e que desempenha papel fundamental na construção da imagem de uma Alemanha "moderna e democrática" que tem plena consciência de seu passado e que sabe muito bem "elaborá-lo", imagem fortalecida ainda mais depois da queda do muro e da Reunificação que submeteu os alemães a uma segunda Vergangenheitsbewältigung, que coloca nazistas e comunistas no mesmo rol de criminosos do passado (diga-se de passagem que desde a divisão da Alemanha entre os aliados, o anti-comunismo passou a ser constitutivo da RFA). Digase de passagem, processo no qual professores marxistas da antiga RDA, mesmo quando críticos oposicionistas da União Soviética, não só foram exonerados como desmoralizados enquanto colaboradores de um regime totalitário, pessoas desprovidas de autonomia intelectual. Como diz Jean Améry, trata-se da "principal mistificação política estatal do pós-guerra, que define o comunismo e o nacional-socialismo como manifestações não muito diferentes de uma mesma coisa." Jean Améry, Além do crime e castigo: tentativas de superação, p.65.

${ }^{29}$ Ulricht Battis, Günther Jakobs, Eckhard Jesse, Josef Inensee. Vergangenheitsbewältigung durch Recht, Drei Abhandlungen zu einem deutschen Problem. 1992, p. 716.
} 
ameaçadora do que a sobrevivência de tendências fascistas contra a democracia. ${ }^{30}$

Nas Minima Moralia, livro de fragmentos escrito em sua maior parte ainda durante a guerra, Adorno especula sobre a "reconstrução" que virá, que dá ao futuro um caráter de farsa. "Reconstruir" uma sociedade que se auto-destruiu é uma contradição em termos. Uma sociedade reconstruída depois da catástrofe só se constituirá como "uma nova qualidade de sociedade" - que é a perpetuação do ocorrido ${ }^{31}$. Há algo irreversível nessas "feridas do espírito",32:

O pensamento de que após esta guerra a vida possa prosseguir 'normalmente' ou que a civilização possa ser 'reconstruída' como se a reconstrução da civilização por si só não fosse a negação desta - é uma idiotice. Milhões de judeus foram assassinados, e isso deve ser um mero entreato e não a própria catástrofe. $\mathrm{O}$ que afinal esta civilização ainda espera? E mesmo se a inúmeras pessoas ainda resta um tempo de espera, como imaginar que o que aconteceu na Europa não tenha consequências, que a quantidade de vítimas não se converta em uma nova qualidade de sociedade: a barbárie estará perpetuada. ${ }^{33}$

Reconstrução da civilização é, portanto, um oxímoro. Entretanto, no âmbito da vida prática, os membros dos Instituto de Pesquisa Social, em seu retorno a Frankfurt, participaram da reconstrução da Alemanha (se a contragosto ou não, pouco importa), mesmo que, ainda durante a guerra, Horkheimer tenha escrito, em tom de manifesto e com perspectivas francamente revolucionárias, que a teoria não deve fornecer nenhum "programa para a próxima campanha eleitoral" e tampouco "para a reconstrução da

\footnotetext{
${ }^{30}$ Adorno, "Was bedeutet: Aufarbeitung der Vergangenheit", p. 555-6. Tradução de Wolfgang Leo Maar disponível em: https://www.marxists.org/portugues/adorno/ano/mes/passado.htm

${ }^{31}$ Para Sartre, também havia uma continuidade do estado de guerra: "Nous avons cru preuve que la paix était l'état naturel et la substance de l'Univers, que la guerre n'était qu'une agitation temporaire de sa surface. Aujourd'hui nous reconnaissons notre erreur: la fin de la guerre, c'est tout simplement la fin de cette guerre. [...] Si l'on nous apprenait demain qu'un nouveau conflit vient d'éclater, nous dirions: 'C'est dans l'ordre', avec un haussement d'épaules résigné." Sartre, "La fin de la guerre", p. 66. Esse "estado de guerra" continuaria no pós-guerra, em uma normalidade que era um estado de prontidão, sob a forma da Guerra Fria: “[...] a Guerra Fria baseava-se numa crença ocidental, retrospectivamente absurda mas bastante natural após a Segunda Guerra Mundial, de que a Era da Catástrofe não chegara de modo algum ao fim [...]." Hobsbawm, Era dos Extremos, p. 228.

${ }^{32}$ A esta altura já não se poderia mais dizer, como Hegel, que as feridas do espírito se curam sem deixar cicatrizes, visto que a história perdeu sua dimensão curativa.

${ }^{33}$ Adorno, Minima Moralia, p. 51. Doravante, MM. (Tradução de Bicca utilizada para este trecho).
} 
Europa, que os professionais já estão providenciando" ${ }^{34}$. Felix Weil (o provedor original do Instituto), que havia ficado nos Estados Unidos, já não iria sustentar mais as pesquisas em Frankfurt (ao que parece, sua empresa não rendia mais como antes), e quando Horkheimer precisou ir atrás de fundos, não hesitou em ressaltar o papel do Instituto na reconstrução nacional. ${ }^{35}$ Da mesma forma, não há como deixar de ver ressoar na famosa ideia adorniana de "Educação após Auschwitz" o contexto do programa dos aliados da reeducation e da "desnazificação", ${ }^{36}$, segundo o qual a política educacional seria um dos pilares fundamentais da reconstrução ${ }^{37}$. Quando finalmente em 1953 Adorno conseguiu ocupar uma cátedra na Universidade de Frankfurt (onde muitos dos professores ativos na época haviam feito carreira durante o nazismo), isso ocorreu no contexto das políticas de reparação do Estado com a criação de uma "cátedra de reparação",38

${ }^{34}$ Horkheimer, Autoritärer Staat, p. 77.

${ }^{35}$ Em um modelo para cartas a patrocinadores, assinado pelo diretor do Instituto, justifica-se: "Análises sociológicas podem esclarecer muitos problemas políticos e sociais decisivos do período do pós-guerra, como o problema dos refugiados. Elas podem fornecer uma base importante e confirmada pela experiência à reconstrução das cidades e das regiões industriais. Uma formação nos métodos da pesquisa social pode ajudar a juventude a melhor compreender as tensões existentes dentro de seu próprio país e entre nações e, portanto, a trabalhar, por sua vez, a superá-las..." Apud Wiggershaus, A Escola de Frankfurt, p. 468. Não se trata aqui de recair na posição moralista de cobrar "integridade de caráter" de intelectuais de oposição, ou de caricaturizar o Instituto como "ornamento crítico de uma sociedade de restauração", como o faz Wiggershaus, mas de apontar essa "vida dupla" do intelectual, que age "a favor" mesmo sendo "do contra". De todo modo, não é de se desprezar um certo engajamento (não no sentido sartriano) dos membros do Instituto na reconstrução e "desnazificação" da RFA; afinal, eram poucos os intelectuais que haviam retornado para a Alemanha. Retomaremos mais adiante o problema da "participação".

${ }^{36}$ A "reeducation" era um programa oficial dos aliados para a Alemanha no término da guerra. A construção da "culpa coletiva" era a primeira diretriz de Robert McClure, especialista em Psychological Warfare, e que explicou na época o procedimento à imprensa americana: "Os primeiros passos da Reeducação [Reeducation] se delimitarão rigorosamente em apresentar aos alemães fatos irrefutáveis, para criar uma consciência da culpa de guerra da Alemanha assim como uma culpa coletiva para os crimes que foram cometidos nos campos de concentração." Apud Christoph Kutschker, Deborah Landau. Ein Gründungsdilemma der deutschen Erinnerungskultur. https://journals.ub.uniheidelberg.de/index.php/ritualdynamik/article/viewFile/352/336 Acesso: 24/09/2018

${ }^{37}$ Se há um vínculo mais profundo entre esse processo histórico a ideia de "reconstrução normativa" ou "crítica reconstrutiva" nos debates em torno de Habermas e Honneth (mesmo que posteriores), fica como questão em aberto.

${ }^{38}$ Embora a interpretação seja equivocada, não é algo totalmente fora de contexto quando Alain Badiou vê a Dialética Negativa como, fundamentalmente, uma "ética da reparação": "Du point de vue de l'aspect programmatique de la différence, la différence doit commencer, ce qui est possible uniquement dans un contexte fondamentalment éthique, plutôt que théorique. C'est pourquoi c'est essentiellement dans un contexte de réparation que la différence peut commencer : nous devons reconsidérer les dommages infligés par l'identité à la différence.// On peut donc dire que le systéme d'Adorno est une historialité éthique, c'est-à-dire un programme pour commencer ce qui ne peut commencer que dans le cadre d'une prescription et non d'une deduction. [...] La musique peut-elle être un programme pour la différence? [...] L'art peut-il être um lieu de 
(Wiedergutmachungslehrstuhl). Vale ressaltar que tais reparações não ocorreram sem atrito em um ambiente de antissemitas, a ponto de um professor universitário de Frankfurt ter pronunciado publicamente sobre a nomeação de Adorno que bastava ser judeu e protegido do professor Horkheimer para se fazer carreira. ${ }^{39}$

Entretanto, apesar do envolvimento direto de Adorno e Horkheimer na formação da RFA, Habermas atesta (em tom reprobatório) que "os antigos frankfurtianos não levaram muito a sério a democracia burguesa" ${ }^{40}$ (essa era, aliás, uma das três críticas centrais aos "antigos frankfurtianos" que Habermas faz em entrevista). Podemos dizer que havia um engajamento "prático" na RFA e nos processos de reconstrução, reeducação e desnazificação como possibilidade num mundo sem possibilidades, mas não havia engajamento "de coração", pois estavam conscientes que o que estava sendo erguido era uma fachada para encobrir as feridas históricas, e essa fachada não poderia ser duradoura. ${ }^{41}$ Daí a existência dupla de um judeu alemão emigrado, no caso de Adorno, como assinala Habermas, que oscila entre o "Volkspädagog" de "tom reformista, claramente social-democrata" e o filósofo do "pensamento sobre a totalidade escuro como breu" ${ }^{, 42}$, esse sim um irredutível. ${ }^{43}$

réparation?" Alain Badiou, "La dialectique négative d'Adorno" In: Cinq leçons sur le 'cas" Wagner. Paris: Nous, 2010, p. 49. Parte central do equívoco de Badiou é conferir ao "nãoidêntico" adorniano a positividade da diferença.

${ }^{39}$ Cf. Wiggershaus, A Escola de Frakfurt, p. 504-5.

${ }^{40}$ Habermas, "Dialética da racionalização" in: A nova obscuridade, p. 248

${ }^{41}$ Apesar do radicalismo do nicht mitmachen adorniano, do ideal da não-participação, há uma participação inevitável. Em aula, Adorno aborda essa participação inevitável que não é "de coração": "A forma mais importante de resistência hoje é não participar [nicht mitmacht], e mesmo quando isso não é possível e quando precisamos ter em vista a nossa própria fraqueza e o predomínio das relações, devemos ao menos tentar, ali onde nós precisamos participar, não participar totalmente e fazer um pouco diferente em relação àquele, que executa de coração." PM 1, 28/02/1957. A formulação aqui é frouxa e está aquém da teoria adorniana em geral, mas ao mesmo tempo revela o que é, mesmo para o crítico negativo, a participação.

${ }^{42}$ Habermas, "Filósofos e sociólogos judeus como regressados à antiga Alemanha Ocidental. Uma recordação." In: Na esteira da tecnocracia, p. 43.

${ }^{43}$ Essa caracterização que Habermas faz de Adorno poderia resumir a vida dupla que leva o intelectual radical. Antonio Candido caracterizava Oswald de Andrade de forma semelhante quando dizia que ninguém é vanguardista em tempo integral, isso é: um lado comprometido com os deveres da vida nacional, e o outro, crítico impiedoso de todo o existente. Assim retoma Paulo Arantes, glosando Antonio Candido: "Seria bom lembrar que tampouco Oswald era antropófago em tempo integral mas também pai de família fora do expediente, assim como Mário de Andrade não era só desvairio futurista mas igualmente cidadão esclarecido à frente de iniciativas de utilidade pública como um Departamento de Cultura, só para lembrar a abrangência, e o caráter entranhado como um destino, da dualidade básica da referida Tradição Crítica, um pé do contra, outro a favor, como assinalou certa vez o mesmo Antonio Cândido." Paulo Arantes, Da noite para o dia, p. 139. 
Tanto não foi duradoura a fachada que, para Hermann Lübbe, um filósofo conservador, as "feridas mal cicatrizadas" foram reabertas nos anos 1960, após duas décadas de recalque da fratura da reconstrução, graças a pessoas de má vontade para com a paz nacional (o auge é o antifascismo de 1968). Glosando uma conferência de Lübbe no cinquenterário da ascensão nazista, Habermas escreve:

De início, durante o período da reconstrução, um processo grandioso de consolidação e desoneração teria ocorrido - graças à discrição e à disposição à reconciliação com que os generosos inimigos dos nazistas se depararam diante dos compatriotas incriminados. Só nos anos 1960, julga Lübbe, as feridas mal cicatrizadas foram reabertas pelos jovens revoltados e por algumas pessoas intransigentes da esquerda. Eles ergueram o passado nazista, apresentando-o à consciência política do presente. Eles encerraram a discrição indulgente e começaram uma crítica que desde então ameaça a estabilidade de nossa república. ${ }^{44}$

\section{Um mundo estável: Welfare, regulação do antagonismo e a "fórmula da paz"}

"Marx pensou que tudo estava ficando cada vez pior, e por isso melhor. Ele era muito otimista: tudo está ficando cada vez melhor, e por isso pior." ${ }^{, 45}$ Essa anotação de Adorno de 1963, que deveria integrar um novo livro de aforismos jamais terminado, sintetiza o capitalismo perene $e^{46}$ que se desenvolveu no período do pós-guerra. Sobre os anos 1950, Hobsbawm atesta: "O clima da década de prosperidade era contra a esquerda. Não era tempo de mudança." ${ }^{47}$ Do ponto de vista da reestruturação econômica, esse capitalismo "pós-liberal"48 já se desenvolvia a partir do período pós-crise de 1929,

\footnotetext{
${ }^{44}$ Habermas, "A descontaminação do passado" in: A nova obscuridade, p. 365.

${ }^{45}$ Adorno, "Graeculus", Frankfurter Adorno Blätter VIII, p. 26.

${ }^{46}$ Cf. Vladmir Puzone, Capitalismo Perene: reflexões sobre a estabilização do capitalismo a partir de Lukacs e da teoria crítica. Tese de Doutorado, USP, $2014 .$.

${ }^{47}$ Eric Hobsbawm, Era dos Extremos, p. 278.

${ }^{48}$ Não é coincidência que aquilo que surgiu como "neoliberalismo", na acepção de Dardot e Laval em A nova razão do mundo retomando as análises de Foucault do ordoliberalismo e do liberalismo social, aparece nesse mesmo movimento que visava dar uma resposta ao problema das crises a da tendência ao colapso do capitalismo de laissez faire: "A novidade do neoliberalismo 'reinventado' reside no fato de se poder pensar a ordem de mercado como uma ordem construída, portanto, ter condições de estabelecer um verdadeiro programa político (uma 'agenda') visando a seu estabelecimento e sua conservação permanente." [grifo meu] Pierre Dardot; Christian Laval, $A$ nova razão do mundo, p. 82. O debate que vai do Capitalismo de Estado de Pollock aos neoliberais gira em torno do problema do capitalismo garantido, ou seja, de um capitalismo perpetuado em que predomina a dimensão "política" (gerencial, governamental etc.) dessa forma social.
} 
quando se visava estabelecer um capitalismo garantido em que o potencial interno de crises fosse anulado.

Se aceitarmos a divisão em três eras que Hobsbawm faz do "breve século XX", aquela que estamos considerando é a "do meio": ela sucede a que dá início ao século, a saber, a "Era da Catástrofe", que engloba o período de 1914 até o final da Segunda Guerra Mundial, marcada pela crise do liberalismo, a Grande Depressão, ascensão do nazifascismo e do stalinismo, encerrada com a apoteose do assassinato em massa em Auschwitz e Hiroshima. A "Era de Ouro" é o tempo depois das catástrofes. Explosão do consumo e crescimento econômico movidos pela Segunda Revolução Industrial, constituição do Estado de Bem-Estar Social nos países centrais, pleno-emprego, reformas sociais, (tensa) estabilidade internacional garantida pela ameaça nuclear durante a guerra fria - "les trentes glorieuses" que vão até meados da década de 1970, quando se inicia, segundo Hobsbawm, “O Desmoronamento”, que culmina no colapso da União Soviética. De todo modo, na era que encerra o século: retorno das crises econômicas, crise da sociedade salarial, fim de Bretton Woods, desemprego em massa, crise climática, desmonte do Welfare State. Mantendo esse esquema do século, a "Era de Ouro" do mundo do pós-guerra ganha sentido sob a luz tanto da "Era da Catástrofe" (que Adorno, nosso autor em questão, jamais perdera de vista) quanto do "Desmoronamento" (que é, digamos assim, nossa luz contemporânea). Afinal, como disse Hobsbawm a respeito dos anos dourados: "O dourado fulgiu com mais brilho contra o pano de fundo baço e escuro das posteriores Décadas de Crise." 49

Se quisermos compreender como a "Era da Catástrofe" pariu algo como uma "Era de Ouro" (ou seja, se quisermos atribuir um mínimo de racionalidade histórica a esse período, e não entendê-lo como um milagre), é interessante situar a gênese do Estado de Bem-Estar Social (considerado como uma das maiores conquistas civilizatórias na história do capitalismo) a partir do final da Segunda Guerra Mundial. Antes de tudo, é necessário reconhecer que na Europa havia um potencial revolucionário na luta contra o fascismo, caso ela fosse bem-sucedida. "Para os movimentos de Resistência estava fora de cogitação voltar ao estado de coisas anterior a uma guerra que precisamente nada mais era do que a fuga para frente catastrófica destinada a perpetuar o dito estado de coisas. A Revolução esteve no ar na forma daquela 'oportunidade antifascista'., ${ }^{, 50} \mathrm{O}$ próprio

\footnotetext{
${ }^{49}$ Hobsbawm, Era dos Extremos, p. 253.

${ }^{50}$ Paulo Arantes, Entrevista com Marcos Barreira e Maurílio Botelho, Revista Sinal de menos n. 11, v. 2.
} 
Adorno, refletindo retrospectivamente em sua Dialética Negativa sobre a impossibilidade de se fazer justiça efetiva aos algozes do campo de extermínio por meio do aparato jurídico vinte anos depois naquela Alemanha reconstruída, reconhece a "oportunidade antifascista" da Revolução no final da guerra: "O fundamento histórico da aporia é o fato de, na Alemanha, a revolução contra os fascistas ter fracassado ou, muito mais, o fato de não ter havido em 1944 nenhum movimento revolucionário de massas. ${ }^{.51}$ A segurança social (que mais tarde se revela como questão de segurança pública na guinada punitivista do Welfare para o Warfare State, que por sua vez surge não como degenerescência mas como continuidade do mesmo paradigma securitário) aparece justamente nesse retorno da guerra, como descreve Paulo Arantes:

Ocorre que ao terminar a guerra a Europa já estava sob uma nova Ocupação, desta vez pelas forças militares aliadas. Uma insurreição da militância armada dos partigiani italianos, por exemplo, seria fatalmente dizimada, e certamente com aquiescimento soviético. A rigor, ao sopro utópico do primeiro tempo da Libertação respondeu uma nova Restauração. Nova porque o grande estouro da Libertação a fizera engolir o sucedâneo de uma Revolução que não houve, justamente o Estado Social. Daí sua funcionalidade de mão-dupla. Assim, já durante a guerra, a cada derrota eleitoral dos consevadores, Churchill anunciava que um verdadeiro Welfare State estaria a caminho coroando o esforço de guerra da nação com proteção e segurança do berço ao túmulo. Na França, o Governo Provisório criou em 1945 a Seguridade Social tal como constava no programa do Conselho Nacional da Resistência. Combinaram-se assim uma irresistível (ou melhor, resistível afinal) pressão popular vinda de todas as mobilizações de energia social para guerra e as grandes manobras do alto comando do poder capitalista vitorioso numa resultante bifronte, um sistema de segurança social cuja gestão confiscada pelas novas burocracias racionalizadas durante a guerra anunciava que estávamos ingressando numa nova era sim, uma era de populações administradas, aliás "totalmente", se é fato que à Guerra Total estava dando sequência uma Paz Total, como Paul Virilio preferia chamar a Guerra Fria. Cujo documento de fundação seria o Relatório Beveridge de 1942, nada mais nada menos do que um programa de Seguro Social desenhado pelos Serviços Aliados, em vista da "vida saudável" do cidadão a ser aliviado do fardo maior das necessidades elementares. Neste sentido, não se poderia "documentar" com mais propriedade a ideia, à primeira vista incongruente, de que desde o seu nascedouro um sistema de garantias e provisões sociais na

\footnotetext{
${ }^{51}$ Adorno, Dialética Negativa, p. 239. Doravante, DN.
} 
verdade era um plano de guerra, mais exatamente, concebido para se ganhar uma guerra, e continuar vencendo a seguinte. ${ }^{52}$

Em suma, o Estado de Bem-Estar Social surge como uma espécie de universalização da pensão do veterano de guerra. Paralelo ao argumento bélico-político, não se pode negligenciar que no "curto verão do milagre econômico" (Robert Kurz) a produção real de valor atingiu níveis jamais vistos, sem a qual não seria possível financiar tal aparato. Quando o ministro da economia da RFA Ludwig Erhard publica em $1957 \mathrm{seu}$ livro "Wohlstand für alle [Bem-Estar para todos]", a taxa de crescimento do PIB alemão mantinha-se já há alguns anos estavelmente em torno dos 10\%. A esta altura, não parecia haver qualquer fundamentação empírica em relação às tendências do capitalismo para se insistir na tese de que a pauperização levaria à solidarização entre os trabalhadores e desencadearia um processo revolucionário e nem a lei da queda tendencial da taxa de lucro parecia se confirmar ${ }^{53}$. Parecia se configurar ali uma inédita simbiose entre capital e pessoas, um nível de integração social muito mais radical (que Adorno chamou de "sociedade completamente socializada") do que no capitalismo em sua era liberal. Surgia precisamente o "liberalismo social", que se desenvolvia sob a sombra da concorrência entre sistemas enquadrada pela guerra fria:

Depois de 1945, o liberalismo social e a tradição do reformismo social do "New Deal" marcou a cultura política dos EUA, e as elites da Europa ocidental se comprometeram, sob hegemonia americana, a uma missão de modernização compreendida como progressiva com o apoio de técnicos e experts das ciências sociais. Esse apogeu histórico do "postwar", a modernidade do pós-guerra, está vinculada sobretudo à guerra fria. Ambas são, dito na linguagem da teoria da modernização, "interdepentendes". Elas não coincidem somente temporalmente. ${ }^{54}$

\footnotetext{
${ }^{52}$ Paulo Arantes, Entrevista com Marcos Barreira e Maurílio Botelho.

${ }^{53}$ Para Adorno, a lei do colapso tal como formulada por Marx, que por sua vez se baseia na lei da queda tendencial da taxa de lucro, poderia estar invisível e escondida naquele momento, mas ela não desaparece. Com acerto ele diz que, a longo prazo, essa tendência se manifestará. Em seu texto sobre a controvérsia do positivismo, ele se refere à: “"lei do colapso' de Marx, deduzida a partir da tendência da queda da taxa de lucro, que hoje se esconde até tornar-se irreconhecível. Seus abrandamentos haveriam de ser por sua vez deduzidos a partir dela, como esforços prescritos imanentes ao sistema, de desviar ou adiar a tendência imanente própria do sistema. De maneira alguma é certo que isto seja possível a longo prazo; como se não ocorresse que tais esforços acabariam por realizar a 'lei do colapso' contra a sua própria vontade. Legível é unicamente a advertência de uma lenta pauperização inflacionária." Adorno, "Introdução à controvérsia sobre o positivismo na sociologia alemã", p. 242 (tradução modificada).

${ }^{54}$ Tim B. Müller, "Innenansichten des kalten Krieges", p. 34.
} 
Claus Offe definiu o Welfare State como uma "fórmula da paz" para uma sociedade de classes de conflitos pacificados e mediados pelo Estado e por sindicatos. ${ }^{55}$ Um consenso era produzido em torno daquilo que, segundo Keynes, garantiria “eficiência econômica, justiça social e liberdade individual" ${ }^{\natural 5}$. O importante é compreender como esses três elementos da fórmula keynesiana deveriam se convergir. Como aponta Javier Blank, na esteira de Offe, neste período do pós-guerra a função de legitimação social ${ }^{57} \mathrm{e}$ de acumulação de valor se retroalimentam, ou seja, a "justiça social", "liberdade individual" etc. não eram barreiras à acumulação de trabalho abstrato, mas constituíam um todo altamente integrado em que se harmonizavam “o social” (que já havia sido inventado $^{58}$ e que era agora objeto da gestão política) e a máquina de valorização do valor $^{59}$. Havia uma complementariedade entre garantir uma "vida decente" e garantir a acumulação, que na época já (ou ainda) não parecia ter limites (isto é, algumas décadas antes de o endividamento público e da financeirização se tornarem mecanismos

55 "The welfare state has served as the major peace formula of advanced capitalist democracies for the period following the Second World War. This peace formula basically consists, first, in the explicit obligation of the state apparatus to provide assistance and support (either in money or in kind) to those citizens who suffer from specific need and risks which are characteristic of the market society; such assistance is provided as a matter of legal claims granted to the citizens. Second, the welfare state is based on the formal role of labour unions both in collective bargaining and the formation of public policy. Both of these structural components of the welfare state are considered to mitigate class conflict, to balance the asymmetrical power relation of labour and capital, and thus to overcome the condition of disruptive struggle and contradictions that was the most prominent feature of pre-welfare state, of liberal capitalism. In sum, the welfare state has been celebrated throughout the post-war period as the political solution to societal contradictions." Claus Offe, The Contradictions of the Welfare State, p. 147.

${ }^{56}$ John Maynard Keynes, "Liberalism and Labour", apud Tim Müller, cit., p. 27.

${ }^{57}$ Sobre o debate entre liberais e marxistas em torno de "legitimação versus eficiência" do Estado, cf. cap. 5 de Claus Offe, Contradictions of the Welfare State.

${ }^{58} \mathrm{Cf}$. Jacques Donzelot, L'invention du social: essai sur le déclin des passions politiques

59 “[...] o Estado promovia tanto a saúde e bem-estar do capital quanto dos cidadãos. O resultado era potencialmente trabalhadores saudáveis, qualificados e empregados e amenização do conflito social. Enfrentar a questão social era preparar as pessoas em idade economicamente ativa para se efetivarem enquanto trabalhadores assalariados, e resolver social e economicamente o vínculo entre os rentáveis e os não rentáveis (trabalhadores domésticos, trabalhadores não produtivos, aposentados, aleijados, crianças)." Javier Blank, "Acumulação sem legitimação e o recrudescimento da violência estatal",

https://www.academia.edu/26450797/Acumulação sem legitimação e o recrudescimento da violência estatal p. 5. Mesmo Axel Honneth reconheceu que, diante da desintegração das estruturas parsonianas de pacificação que predominaram durante essas décadas do pós-guerra (Talcott Parsons era já há décadas o grande teórico do conflito social pacificado), decorre uma brutalização do conflito social. Cf. Axel Honneth, "Brutalization of the social conflict: struggles for recognition in the early 21 th century". Certamente um período em que se rebaixam, para utilizar um termo de Honneth, as "expectativas de reconhecimento". 
estruturais na garantia da produção - fictícia, certamente - de valor). Quanto à satisfação das necessidades básicas daqueles que possibilitavam que a mais-valia continuasse a ser extraída, consolidava-se uma situação que já estava sendo produzida antes de 1945. Nas Reflexões sobre a teoria das classes, que data de 1942, Adorno apontava:

Os proletários têm algo mais a perder do que seus grilhões. Seu nível de vida não piorou, ele melhorou em comparação com as circunstâncias inglesas de cem anos atrás, tal como se apresentava aos autores do Manifesto. Jornadas menores de trabalho; melhor alimentação, habitação e vestuário; proteção para os membros da família e diante da própria velhice; um aumento na expectativa de vida; tudo isto é resultado do desenvolvimento das forças técnicas de produção. De forma alguma se pode dizer que a fome vai leválos necessariamente a uma união incondicional e à revolução. ${ }^{60}$

O que se desenhava era o que Adorno chamou de pseudo-morfose da sociedade de classes em uma sociedade sem classes $^{61}$ : basicamente um capitalismo que se fingia de pós-capitalista. Ou como dizia Horkheimer ainda nos anos 1940 a respeito da reorganização do capitalismo: "O capitalismo de Estado aparece às vezes quase como paródia da sociedade sem classes." ${ }^{62}$ Adorno via que a sociedade ainda era fundada no antagonismo de classe, mas que não mais haveria luta de classes no sentido emancipatório, e sim somente como mecanismo interno de regulação sistêmica. Porém, ele fala diversas vezes de uma "invisibilização" da luta de classes: por mais que ela não seja manifesta, ela torna-se latente (retomando o motivo de Gumbrecht em torno das latências do pós-guerra). O que se desenvolve no período pós-guerra é, nos termos de Tim Müller, uma "era de neutralizações e despolitizações de conflitos políticos e ideológicos endógenos." 63 Adorno observou com precisão que essa neutralização e despolitização daquilo que aparece no capitalismo sob a forma explosiva da luta de classes levava ao surgimento do conceito sociológico de "social conflict" ${ }^{64}$ No acertado ensaio "Considerações sobre o conflito social hoje", que Adorno escreveu em conjunto com sua aluna Ursula Jaerisch, foi identificada a transformação da ideia de conflito em

\footnotetext{
${ }^{60}$ Adorno, "Reflexionen zur Klassentheorie", p. 384.

61 "A pseudo-morfose da sociedade de classes em uma sociedade sem classes foi tão exitosa, que os oprimidos são absorvidos, mas toda opressão se tornou manifestamente supérflua." Adorno, "Reflexionen zur Klassentheorie", p. 39.

${ }^{62}$ Horkheimer, "Autoritärer Staat", p. 75.

${ }^{63}$ Müller, cit., p. 36.

${ }^{64}$ Cf. Yasmin Afshar, Materialismo sem imagens. Dissertação de mestrado. Universidade de São Paulo, 2018.
} 
ideologia da pacificação, em suma, uma verdadeira "transfiguração ideológica" ${ }^{65}$ daquilo que aparece como elemento interno de tensão. Na proeminente teoria do conflito social, que tinha Parsons como seu representante maior no âmbito internacional e Ralf Dahrendorf no contexto alemão, o conflito torna-se algo a ser gerido: "O controle social dos conflitos já é pensado implicitamente, eles deveriam ser 'regulados', 'guiados' de forma 'enérgica' e 'canalizados'., ${ }^{66}$ Nesse mesmo período, o jovem Habermas testemunhava a transformação da política em gestão ${ }^{67}$ : processo em que o encaminhamento das expectativas de efetivação da liberdade por meio da ação humana é convertido em "resolução de problemas técnicos" que visa o mero funcionamento do aparato de acumulação:

Na medida em que a atividade estatal é direcionada à estabilidade e ao crescimento do sistema econômico, a política assume um peculiar caráter negativo: ela se orienta pela eliminação de disfuncionalidades e prevenção dos riscos que possam ameaçar o sistema, ou seja, ela não é direcionada à realização de finalidades práticas, mas à resolução de problemas técnicos. ${ }^{68}$

\footnotetext{
${ }^{65}$ Como notou Afshar a respeito do que o próprio Adorno diz sobre a ideia de "parceria social" como transfiguração ideológica das descontinuidades e antagonismos sociais. Em aula, Adorno diz: "Eu recomendaria a vocês [...] o maior ceticismo com relação a este conceito de pluralismo oferecido hoje em todos os cantos, do mesmo modo que com o de "parceiros sociais". Acrescentese a isso a tendência ideológica geral a transfigurar - como é tão característico de nossa época de modo ideológico os momentos de descontinuidade, ou os momentos do antagonismo social, apresentando justo aquilo que na realidade ameaça realmente lançar pelos ares o todo como se fosse um 'ser um com o outro' pacífico dos homens, que teriam se reconciliado e que não precisariam mais de luta; uma tendência na qual quase se esconde que a humanidade começa a se desesperar com a possibilidade de que esses conflitos sejam resolvidos." Adorno, Zur Lehre von der Geschichte und von der Freiheit, p. 140. Doravante, ZLGF.

${ }^{66}$ Adorno, "Anmerkungen zum sozialen Konflikt heute", p. 181. Dahrendorf se refere explicitamente ao conflito como meio de governo: "Democracia liberal é governo por meio de conflito." Dahrendorf, Gesellschaft und Demokratie in Deutschland, p. 174, apud Afshar, cit., p. 85.

${ }^{67}$ A despolitização da política, isto é, a transformação da política em gestão técnica é um excelente meio político, já observava Carl Schmitt em 1932: "Há mais ou menos dez anos, toda a Alemanha e o todo o planeta faziam ecoar: abaixo a política! Era tido como solução para todos os problemas eliminar a política, o Estado e decidir todas as questões por meio de perícia técnica e econômica. [...] Revelou-se que um tal tipo de despolitização pode ser um meio político útil para adiar problemas desagradáveis e mudanças necessárias e para fazer rodar em falso toda vontade decidida." Carl Schmitt, "Starker Staat und gesunde Witschaft". Mas como nota o próprio Schmitt, essa "era de despolitização e neutralização" marcada por um primado da técnica produzia o seu contrário, a saber, a politização de tudo: o Estado Total (que é, a rigor, uma tendência imanente à tecnocracia).

${ }^{68}$ Habermas, "Técnica e ciência como "ideologia", p. 105. Como em muitos dos momentos decisivos de sua teoria, Habermas se apoiava aqui em Offe, que enxergava que "[...] a 'política' se degenera em uma ação que obedece aos numerosos e sempre novos "imperativos de prevenção", em que o sentido de governar se revelava como "antever as zonas de risco futuro" e "determinar o melhor tratamento às ameaças atuais". Claus Offe, Zur Klassentheorie und Herrschaftsstruktur im staatlich regulierten Kapitalismus apud Habermas, idem, p. 106. Ou seja,
} 
A luta de classes assume neste contexto não mais um teor político (ou "prático", no sentido alemão do termo), mas puramente técnico: caberia decidir se ela é disfuncional ou não. O "conflito social” é por um lado a própria luta de classes institucionalizada ${ }^{69}$ (que aparecia como conflito entre quaisquer grupos sociais ${ }^{70}$ ), mas sobretudo ele não era mais algo como uma contradição fundamental que pulsava enquanto potencial de transformação radical da sociedade, muito pelo contrário: o conflito, visto como essencial às sociedades democráticas saudáveis e funcionais, é perenizado como "dinâmica" em uma sociedade antagônica, porém pacificada, estável.

Em um discurso de 2009, num evento de comemoração do aniversário de 80 anos de Dahrendorf em Oxford, Habermas resume: "Os conflitos sociais, que em última instância são fundados sempre em relações de dominação, impelem a dinâmica social; são algo desejável e não devem ser dissolvidos, mas institucionalizados e decididos de forma civil." ${ }^{71}$ Em suma, a transistoricização do conflito social (“onde há vida humana em sociedade, há também conflito"72 ) não deixa de ser uma ontologização de relações sociais baseadas na dominação, mas que por sua vez seriam reguladas, e cujos efeitos nocivos, na medida do possível, amenizados. O conflito não poderia jamais, entretanto, ser abolido. Lembremos que não somente sociólogos liberais encampavam tal concepção, mas também no campo francês, de Lacan a Lefort, o conflito tornava-se algo eterno (seja como elemento constitutivo do psiquismo ou da vida política) $)^{73}$ - marca ideológica por

a racionalidade neoliberal do gerenciamento de riscos (e do "governo de populações", para dizer como Foucault) não é uma degenerescência da racionalidade welfarista, mas pode ser vista como um desdobramento desta.

69 "A integração da luta de classes na institucionalização das associações e partidos que competem entre si funda o esquema, que afirma e suaviza o conflito, das teorias do conflito contemporâneas.” Adorno, “Anmerkungen zum sozialen Konflikt heute”, p. 181.

${ }^{70}$ Segundo Dahrendorf: "A categoria de grupos de interesses é uma categoria geral; todos os grupos secundários devem ser entendidos como grupos de interesse - um clube de xadrez, uma associação profissional, um clube de futebol, assim como um partido político ou uma classe social." apud Afshar, cit.

${ }^{71}$ Habermas, "Racionalidade de paixão. Ralf Dahrendorf em seu aniversário de 80 anos" in: $\mathrm{Na}$ esteira da tecnocracia: Pequenos escritos políticos XII, p. 211.

${ }^{72}$ Dahrendorf apud Afshar cit.

${ }^{73}$ Como defende Dario de Negreiros, há uma "homologia estrutural entre o social lefortiano e o sujeito lacaniano, ambos marcados pelas presenças de: (i) uma cisão originária, (ii) um conflito irredutível, (iii) uma opacidade fundamental e (iv) um vazio constitutivo. Mais: tanto o Sujeito lacaniano quanto o Sujeito político lefortiano não podem encontrar outro fundamento para seus atos - não raro, atos que devem se colocar para além da Lei - senão em um desejo essencialmente negativo. [...] numa formulação que encontra na simplicidade, didática e provocativa, a sua justificação: negar a divisão, o vazio, o conflito e a opacidade, para o sujeito lacaniano, constitui a essência do patológico e, no limite, da loucura; para o social lefortiano, esta mesma negação 
excelência das sociedades ocidentais pacificadas do pós-guerra. A abolição do conflito era vista, em todos os cantos, como uma utopia totalitária (soviética) e patológica. ${ }^{74}$ Por outro lado, não há nada mais antiutópico que o conflito gerenciado. Retrospectivamente, Habermas toma a seguinte posição a respeito de Dahrendorf: "Na época, não tinha cabimento o traço antiutópico de um liberalismo de mercado, por mais que tivesse uma âncora democrática e igualitária. Mas depois o impulso do cientista apaixonadamente engajado e do pedagogo popular [Volkspädagog], adepto do Esclarecimento, voltou a me arrebatar." importante ao longo do caminho da Alemanha até si mesma [...] [grifo meu]." ${ }^{, 76} \mathrm{~A}$ pacificação do pós-guerra é certamente a pedra de toque da Alemanha contemporânea.

A ideia de "conflito social", como toda ideologia, porta uma verdade. "Enquanto categoria sociológica, o conflito emerge somente com o desaparecimento da concorrência em sua forma antiga e da luta de classes manifesta. Nessa medida, a categoria é adequada." 77 Ou seja, a categoria de conflito descreve a realidade, em alguma medida,

é a essência do autoritarismo e, no limite, da sociedade autoritária." O Maquiavel de Lefort e a crítica ao idealismo democrático. Dissertação de Mestrado, USP, 2017, p. 114, [grifo meu]. Ou seja, o desejo utópico de paz, de resolução verdadeira dos conflitos, é um desejo patológico, visto que, tal como defendia Dahrendorf e os teóricos do social conflict, o conflito, a clivagem e o vazio fazem parte da natureza humana finita. De forma distinta de Lefort, mas ainda numa perspectiva lacaniana, Zizek defende que a reconciliação (tema forte da superação dos antagonismos na tradição marxista) não é uma reconciliação da realidade, ou seja, o caráter conflituoso e contraditório da realidade é perene, é de sua natureza, e portanto, eterno. A reconciliação é, pelo contrário, algo que ocorre somente na consciência - ela é uma mudança de ponto de vista. Diz ele: "Em suma, o engano máximo reside na incapacidade de ver que já temos aquilo que estamos procurando (...) como vimos, longe de envolver a intervenção mágica de um deus ex machina, é uma reviravolta puramente formal, uma mudança de perspectiva: a única coisa que muda na reconciliação final é o ponto de vista do sujeito - o sujeito endossa a perda, reinscreve-a como seu triunfo." Slavoj Zizek, Menos que nada: Hegel e a sombra do materialismo dialético.

${ }^{74}$ Essa apologia do conflito nas sociedades pacificadas aparece também de forma exemplar em Honneth, que diz: "The concern with the struggle for recognition is linked to a revision of classical conceptions of conflict. For what is crucial in this context is the connection between 'the conflictual' and 'the peaceful'. Conflicts over forms of sociality lie at the heart of human life forms. What is at stake in these conflicts is not distance in relation to others, or domination over others, but the desire for belonging, the desire to be a fully fledged member with equal rights. In this light, the concept of conflict acquires a meaning which is utterly different from the sense it is given in most conflict theories. To the extent that the interest in 'being respected' and the interest in 'being part of a community' are fundamental to conflict, we are dealing with conflicts over inclusion, ratherthan with conflicts over exclusion." Axel Honneth, "Sociology of Critique or Critical Theory? Luc Boltanski and Axel Honneth in Conversation with Robin Celikates" in The Spirit of Luc Boltanski. Essays on the 'Pragmatic Sociology of Critique. Turner: Anthem Press, 2014.

${ }^{75}$ Habermas, "Racionalidade de paixão. Ralf Dahrendorf em seu aniversário de 80 anos" in: $\mathrm{Na}$ esteira da tecnocracia: Pequenos escritos políticos XII, p. 212.

${ }^{76}$ Ibid.

${ }^{77}$ Adorno, “Anmerkungen...”, p. 182. 
adequadamente - mas ela é imprópria para a explicação da realidade em um nível mais profundo dos nexos sociais, ao mesmo tempo em que ela distorce a história ao ser transposta para um nível antropológico. Ela descreve processos sociais e ao mesmo tempo os mascara: "O termo conflito social desvia de seu horror fatal assim como de sua base nos antagonismos objetivos." ${ }^{, 78}$ Esse mascaramento, porém, não é algo simplesmente que esconde a realidade, mas é algo da realidade no sentido de que é algo que desempenha um papel estruturante da própria realidade (sinteticamente, é esse o conceito adorniano de ideologia). "A onipotência da repressão e sua invisibilidade são a mesma coisa."

A luta de classes passa de elemento sistêmico disfuncional a elemento funcional: a contradição interna que ameaça explodir o sistema tranforma-se no próprio mecanismo de reprodução social por meio das novas estruturas sindicais ${ }^{80}$ : essa era, por excelência, o cerne da expectativa social-democrata expressa, por exemplo, por um Hilferding (que havia sido ministro na República de Weimar e figura central do SPD), que acreditava que a reestruturação econômica no capitalismo organizado "poderia ser perfeitamente

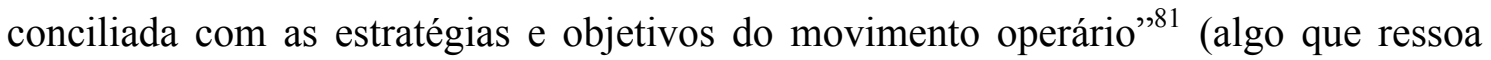
inclusive na teoria de Pollock do capitalismo de Estado em sua versão democrática). Já para Adorno, "a imagem diabólica da harmonia" revela dominação na falsa reconciliação (que era a palavra que denominava também a pacificação do outro lado da cortina de ferro, a saber, o stalinismo). "A luta de classes do velho estilo, no sentido do manifesto de Marx, tornou-se, como disse Brecht, virtualmente invisível. Sua invisibilidade mesma não deve ser separada dos problemas estruturais. De fato, as manifestações das relações de classe foram em larga medida embutidas no nexo funcional da sociedade, determinadas enquanto parte de seu funcionamento [grifo meu]." 82 Apesar dessa transfiguração real, a sociedade permanecia um "todo não pacificado". ${ }^{83}$

\section{Capitalismo perpétuo e crise imanente}

Essa transformação do antagonismo social em conflito gerenciável e funcional, algo crucial para o capitalismo "organizado" e "garantido", não pode ser vista como uma

\footnotetext{
${ }^{78}$ Ibid.

79 Adorno, "Reflexionen zur Klassentheorie", p. 377

80 “Os sindicatos tornam-se monopólios e os funcionários, bandidos que exigem obediência cega dos trabalhadores [Zugelassenen].” Adorno, "Reflexionen zur Klassentheorie” p. 380.

${ }^{81}$ Cf. Puzone, cit., p. 109

${ }^{82}$ Adorno, “Anmerkungen...", p. 183.

${ }^{83}$ DN, p. 133.
} 
operação sem restos, ou seja, completamente bem-sucedida e definitiva. O sistema produtor de mercadorias permanece, em sua essência, contraditório. Este texto de 1968 (“Observações sobre o conflito social hoje") é um dos poucos momentos em que Adorno fala explicitamente da possibilidade de crise na qual a luta de classes, enquanto algo latente, poderia por fim se atualizar (crise entendida aqui no sentido moderno "clássico", portanto como algo que exige uma decisão e aponta uma passagem para algo outro, uma abertura de futuro): "De todo modo, esta harmonia provavelmente não é tão duradoura como tentam iludir por meio da afirmação de que aquela teoria crítica da qual querem se livrar de forma definitiva está ultrapassada ao relegá-la à metafísica." (Trata-se aqui da desconfiança da sociologia positivista em relação a categorias pouco "científicas" como contradição, totalidade social etc.) "Em situações de crise, o conflito social pode se atualizar na forma de um conflito de classes; se novamente nas formas do mundo administrado, aguardemos." ${ }^{84}$ No mundo administrado e integrado, porém contraditório, há uma espécie de energia represada, que na crise - e essa aparece como a possibilidade mais plausível - explodirá rumo à desintegração social. Certos grupos sociais intermediários não organizados, que experimentarão privação e pobreza, escreve Adorno, portam um "potencial”: "Este potencial é um potencial de desintegração [Desintegration]. A desintegração [Zerfall] em partículas centrifugais é o reverso da integração social." ${ }^{~} 5$

A recusa da tese de Friedrich Pollock a respeito da harmonização política das contradições econômicas não poderia ser mais explícita, pois, como se sabe, foi Pollock quem, no círculo dos frankfurtianos, enfatizou a ideia de um capitalismo sem crise (que, a rigor, seria um oxímoro, pois contradiz a própria ideia de capital) por meio do conceito de "capitalismo de Estado". Não pretendo reconstituir aqui em detalhes esse debate dos anos 1930 e $1940,{ }^{86}$ mas ressalto alguns pontos dessa pseudo-abolição da natureza contraditória da acumulação de valor por meio do Estado. É evidente que tais considerações já soam hoje, em um momento em que a dinâmica de crise retorna com força, disparatadas, tendo elas se tornado muito mais fáceis de serem desmentidas. Porém, por mais que equivocadas em aspectos cruciais, elas apontam transformações estruturais do capitalismo que ainda ressoam no mundo contemporâneo. Henryk Grossmann, que era próximo de Carl Grünberg e do primeiro círculo de frankfurtianos, havia publicado em

\footnotetext{
${ }^{84}$ Adorno, “Anmerkungen...", p. 186.

${ }^{85}$ Adorno, “Anmerkungen...", p. 188.

${ }^{86}$ Para citar algumas pesquisas mais recentes no meio universitário brasileiro: cf. Puzone, Pedroso e Fleck; de Caux.
} 
1929 Das Akkumulations- und Zusammenbruchsgesetz des kapitalistischen Systems [A lei de acumulação e do colapso do sistema capitalista $]^{87}$, em que o colapso do capitalismo era compreendido não como provocado por causas externas a ele, mas, segundo a própria teoria de Marx, constituía sua lei imanente. No livro III d'O Capital, Marx afirmava: “A verdadeira barreira da produção capitalista é o próprio capital, isto é: que o capital e sua autovalorização apareçam como ponto de partida e ponto de chegada, como motivo e finalidade da produção [...]." ${ }^{\text {88 }}$ Ou seja, um limite interno é inerente à "produção como uma finalidade em si mesma" 89 . É inerente ao desenvolvimento capitalista expulsar trabalho vivo do processo produtivo, ao mesmo tempo em que o trabalho permanece como sua única fonte de valor real. A “elevação da força produtiva [...] sempre anda lado a lado com a desvalorização do capital existente." 90 A alteração da composição orgânica do capital $^{91}$, isto é, a diminuição relativa do quantum de trabalho vivo (capital variável) objetivado em uma mercadoria em relação ao capital constante (maquinaria), estimulada pela concorrência e pelo desenvolvimento das forças produtivas, tem uma dinâmica de crise, isso é, ela nega seus próprios fundamentos segundo sua lei interna:

[A produção capitalista], com o progressivo decréscimo relativo do capital variável em relação ao capital constante, gera uma composição orgânica crescentemente superior do capital global, cuja consequência imediata é que a taxa de mais-valia, com grau constante e até mesmo crescente de exploração do trabalho, se expressa numa taxa geral de lucro em queda contínua. [...] A tedência progressiva da taxa geral de lucro a cair é, portanto, apenas uma expressão peculiar ao modo de produção capitalista para o desenvolvimento progressivo da força produtiva social de trabalho. [...] Como a massa de trabalho vivo empregado diminui sempre em relação à massa de trabalho objetivado, posta por ele em movimento, isto é, o meio de produção consumido produtivamente, assim também a parte desse trabalho vivo que

\footnotetext{
${ }^{87}$ Henryk Grossmann, Das Akkumulations- und Zusammenbruchsgesetz des kapitalistischen Systems. Leipzig, 1929. "Para Marx [...], o colapso é um resultado imanente, que segue da própria regularidade econômica do mecanismo capitalista." Idem, p. 48 A esse respeito, ver o capítulo "Do colapso ao capitalismo de Estado" da tese de Vladimir Puzone.

${ }^{88}$ Marx, O Capital III.1, p. 189.

${ }^{89}$ Ibid.

${ }^{90}$ Ibid., p. 187.

${ }^{91}$ Adorno não só conhecia a teoria do colapso de Marx e acreditava que a lei da queda tendencial da taxa de lucro mantinha-se válida, como utilizou o conceito marxiano de "composição orgânica do capital", para, em sua Minima Moralia, falar de uma "composição orgânica do homem": "Cresce a composição orgânica dos homens. Aquilo pelo qual os sujeitos em si próprios são determinados como meios de produção, e não como fins vivos, aumenta da mesma forma que a proporção das máquinas relativamente ao capital variável.” MM, p. 226.
} 
não é paga e que se objetiva em mais-valia tem de estar numa proporção sempre decrescente em relação ao volume de valor do capital global empregado. Essa relação da massa de mais-valia com o valor do capital global empregado constitui, porém, a taxa de lucro, que precisa, por isso, cair continuamente. ${ }^{92}$

Ou seja, com uma taxa descrescente do lucro, para manter uma massa de lucro constante, é necessária uma quantidade de capital empregado sempre crescente. Por um período, a constante expansão do mercado buscou dar conta dessa contradição interna. ${ }^{93}$ Mas o que Pollock observou após a crise de 1929 e durante a ascensão do fascismo era algo que parecia ser a anulação dessa lei em decorrência da abolição da esfera da circulação e da concorrência como mecanismo regulador de preços. Parecia configurarse "uma importante modificação estrutural, que põe sob ameaça o automatismo do mercado." "94 Entre os novos fenômenos, observava-se o surgimento dos grandes monopólios com uma burocracia estatal de total influência sobre a produção e a circulação de mercadorias e a ascensão do manager como figura principal de poder. " $\mathrm{O}$ El Dorado da existência burguesa, a esfera da circulação, foi liquidada." ${ }^{95}$ Com a ideia de planejamento, as leis capitalistas apareciam como leis da natureza que haviam sido domadas por uma razão subjetiva. Horkheimer, em "O Estado Autoritário", viu esse processo não como um desenvolvimento anômalo do capitalismo, mas como a sua própria verdade: "o automovimento do conceito de mercadoria leva ao conceito de capitalismo de Estado, assim como em Hegel a certeza sensível leva ao saber absoluto."96 Ou seja, diversamente daquilo que Adorno chamou de "fenomenologia do anti-espírito" na exposição d'O Capital que leva "da análise da forma da mercadoria até a teoria do colapso" 97 , a verdade do capitalismo não era o seu fim, mas sua estabilização rumo à

\footnotetext{
${ }^{92}$ Marx, O Capital III.1, p. 164. Vale notar que no debate marxista contemporâneo há uma polêmica em torno da lei da queda tendencial, que não cabe reproduzir aqui. De todo modo, há uma série de autores que enfatizam que há uma preponderância das contra-tendências, e que na verdade tal lei não se confirma, de modo que a produção real de valor continuaria a todo vapor. O caráter ideológico e negacionista em relação à tendência de colapso do capitalismo por parte de setores da esquerda revela nada mais nada menos que a histórica defesa do trabalho (produtor de valor real), sem o qual não haveria sustentação política e moral para tal esquerda. Não é por outro motivo que Robert Kurz afirma que "a desmoralização histórica da esquerda coincide com o fim da capacidade do capitalismo de se desenvolver."

93 "A contradição interna procura compensar-se pela expansão do campo externo da produção." Marx, O Capital III.1, p. 185.

${ }^{94}$ Pollock, A situação atual do capitalismo e as perspectivas de uma nova ordem de planificação econômica (1932), trad. Luiz de Caux e Amaro Fleck, manuscrito, p. 30.

${ }^{95}$ Horkheimer, "Autoritärer Staat", p. 55

${ }^{96}$ Horkheimer, "Autoritärer Staat", p. 68.

${ }^{97}$ DN, p. 294-295.
} 
eternidade. "O capitalismo de Estado elimina o mercado e hipnotiza a crise pela duração da eterna Alemanha." "98 A eliminação do elemento contraditório e dos limites internos era a eliminação do elemento temporal, daquilo que fazia do capitalismo uma coisa finita, portanto, algo cuja verdade, ao menos segundo Hegel, é seu fim. A promessa de Hitler de que o Terceiro Reich duraria mil anos parecia uma ameaça real. ${ }^{99}$

Um dos elementos cruciais dessa "transformação estrutural" do capitalismo é que a dominação econômica impessoal do trabalho abstrato havia aparentemente perdido sua relevância frente à dominação pessoal direta: "Sob o capitalismo de estado, os homens aparecem como comandantes ou comandados. "100 A dominação mediada, determinada pela forma social, assumia uma forma sem mediações, havia se convertido em dominação subjetiva. Também Franz Neumann, que discordava de Pollock e polemizou contra ele, falava de uma "economia de mando" [Befehlswirtschaft]. No fascismo, "o chicote do desemprego foi substituído pelo terror político."101 Isso colocava um grave problema para a teoria crítica que se compreendia como continuação direta da crítica da economia política, pois, segundo Pollock, "sob o capitalismo de Estado, a economia enquanto ciência social perdeu seu objeto." ${ }^{102}$ Se no período liberal do capitalismo, que engloba o século XIX e o início do XX, a determinação econômica se sobrepunha à esfera política, o que se desenhava para Pollock era uma nova era do capitalismo em que a política (entendida aqui como regulação estatal) passa a definir as normas de funcionamento da reprodução social: "A substituição dos meios econômicos por meios políticos como a última garantia para a reprodução da vida econômica muda o caráter de todo o período histórico. Isto significa a transição de uma era predominantemente econômica para uma era essencialmente política."103 Seria necessário talvez precisar que aquilo que Pollock chama de "guinada política" do capitalismo é na verdade uma guinada gerencial. Ou seja, ela não passa por aquilo que Habermas entende por política no sentido de estabelecimento de "finalidades práticas", como a vida boa, a emancipação etc., mas é caracterizada sobretudo por aquilo que ele via como uma racionalidade tecnocrática, isto é, voltada para o bom funcionamento do sistema dado. A compreensão pollockiana de "política" é

\footnotetext{
${ }^{98}$ Horkheimer, “Autoritärer Staat", p. 56

${ }^{99}$ Essa expectativa não conduz, como por vezes se interpreta, a um pessimismo quietista. No mesmo texto de Horkheimer: "O horror na expectativa de um período mundial autoritário não impede a resistência." Horkheimer, Autoritärer Staat, p. 72.

${ }^{100}$ Pollock, Capitalismo de Estado, trad. Luiz de Caux e Amaro Fleck, manuscrito.

${ }^{101}$ Ibid.

${ }^{102}$ Ibid.

${ }^{103}$ Ibid.
} 
demasiado pobre: por isso ele vê como alternativa à "versão autoritária" do capitalismo de Estado uma "versão democrática" (algo que não é cogitado por Horkheimer em seu “Estado Autoritário"). Por essa razão não existe efetivamente uma versão democrática em sentido enfático do capitalismo de Estado: mesmo em sua sobrevida no mundo das democracias liberais do pós-guerra, ele permanece como uma "economia de comando" planejada por tecnólogos sociais independentemente da coloração política.

A tese fundamental de Pollock de que a anulação da dinâmica econômica da circulação por meio do planejamento "vindo de cima" acarretava uma anulação da própria contradição imanente do capitalismo nunca chegou a ser aceita por Adorno, pois seria algo que comprometeria a própria ideia de dialética. Em oposição a isso, Adorno enfatizava que a dialética não era somente movimento da contradição, mas que a estática e a estabilização também eram figuras da dialética: "A dinâmica é meramente $u m$ aspecto da dialética." ${ }^{104}$ Isso incluía ao mesmo tempo uma crítica à concepção da dinâmica como progresso e à estática como fim deste: se o progresso era o sempre-igual, ou seja, não era progresso algum, então a paralisia desse processo não é o fim da (pré-)história. Há uma continuidade entre momentos "dinâmicos" e "estáticos". "Se a dinâmica sempre foi o igual, então seu fim hoje não é o fim." ${ }^{105}$ Visto de outra forma, a ideia de um capitalismo sem crise, isto é, sem contradições internas que o levariam a seu ocaso, não seria um pensamento anti-dialético, pelo contrário: segundo Horkheimer (como consta em notas de conversa feita pelo próprio Pollock), tal ideia seria uma "recaída em Hegel":

Pretende-se dizer com esse conceito [de capitalismo sem crise] que o capitalismo conseguiu superar suas contradições econômicas? Mas se ele é uma sociedade sem contradições, então ele não pode, a partir delas, perecer [zu Grunde gehen]. Uma sociedade sem contradições tem existência ilimitada. / Isso é uma recaída em Hegel, isso é, na afirmação de que há uma forma da sociedade capitalista que significa um destino final na história da humanidade e a qual ela foi adentrada. Claramente essa visão é absurda. Portanto, devem continuar a existir as contradições que fazem do capitalismo uma configuração transitória. Se as contradições apontadas por Marx não são mais efetivas hoje, trata-se de mostrar onde estão essas contradições. ${ }^{106}$

\footnotetext{
104 Adorno, "Reflexionen zur Klassentheorie”, p. 374.

105 Ibid., p. 391.

106 Horkheimer, "Späne. Notizen über Gespräche mit Max Horkheimer" in Max Horkheimer, Gesammelte Schriften in neunzehn Bänden. Frankfurt a. M.: Fischer, 1985 - 1996. (Doravante citado como HGS seguido pelo número do volume). HGS 14, p. 276.
} 
Horkheimer parece aqui escrever justamente o contrário do que ele defendia em seu ensaio "Estado Autoritário", quando dizia que "o automovimento do conceito de mercadoria leva ao conceito de capitalismo de Estado, assim como em Hegel a certeza sensível leva ao saber absoluto."107 De todo modo, é latente na tese do capitalismo de Estado um hegelianismo ao estilo de Fukuyama, que, na esteira de uma interpretação kojèveana, trouxe de volta o tema do fim da história ao final da Guerra Fria. ${ }^{108} \mathrm{Na}$ célebre passagem de uma carta a Horkheimer, Adorno refere-se de forma explícita ao artigo "Capitalismo de Estado" de Pollock:

O melhor modo em que posso resumir minha opinião sobre esse artigo é que ele representa uma inversão de Kafka. Kafka representou a hierarquia dos escritórios como o inferno. Aqui o inferno se transforma numa hierarquia de escritórios. Ademais, o todo é formulado de modo tão tético e, em sentido husserliano, 'a partir de cima', que prescinde completamente de impressividade,

${ }^{107}$ Horkheimer, "Autoritärer Staat", p. 68.

${ }^{108}$ Parêntese: não deixa de existir uma analogia entre o capitalismo perpétuo de Pollock e a crise perpétua contemporânea como catástrofe permanente. Se pensarmos com Koselleck que a ideia de crise está vinculada a uma experiência temporal específica, a saber, a um horizonte de futuro que se abre em uma situação que exige uma decisão, a experiência que temos na crise contemporânea é distinta, o que faz Paulo Arantes questionar se "recorrer à noção de crise ainda faz alguma diferença agora que nossa relação política com o tempo tornou-se inteiramente outra" P. Arantes, Entrevista com Marcos Barreira e Maurílio Botelho. Isto é, a crise que vivemos não é nenhuma contradição imanente que estaria gestando um futuro, uma passagem para o novo a partir de si, pois é "evidência maior do nosso tempo [...] que a decomposição da sociedade capitalista a rigor não anuncia mais nada, quer dizer, mais nada daquelas velhas coisas boas de sempre." Que Paulo Arantes veja em Fukuyama a verdade de um testemunho de época, uma época em que "o tempo do mundo perdeu sua força", corre junto com seu pouco-caso com a ideia de crise. "Recaída em Hegel", como diria Horkheimer? Talvez, afinal esse diagnóstico de época porta uma filosofia da história em sentido enfático. Isso significa que o capitalismo não é mais uma forma contraditória? Ou há uma mudança qualitativa na ideia de contradição? Ou o momento positivo-racional de superação da contradição sempre foi uma mistificação da dialética? Se o colapso do capitalismo não é sua morte necessária, mas é um colapso que persiste, então podemos falar que a dialética capitalista se reproduz, para falar como Adorno, segundo a "lógica da desintegração" em uma espécie de entropia contínua, mas que não parece prometer a morte: "Humor negro à parte, até na morte, na qual a sabedoria moderna nunca deixou de reconhecer a maior crise que uma pessoa pode enfrentar, justamente sua revisão como crise carregaria consigo o sentimento de uma passagem, desta para melhor, como no dito popular. A mudança do clima da história mudou tudo isso." Ibid. Esse não morrer do capitalismo na crise permanente nos remete à doutrina kierkegaardiana do desespero objetivo, tal como analisada por Adorno: “[...] o tormento do desespero consiste justamente em que não se pode morrer. Ele se assemelha mais com o estado agonizante, quando esse jaz no leito e se atormenta com a morte, mas não pode morrer. Assim, estar doente para a morte significa não poder morrer, contudo, não de tal maneira que ainda houvesse esperança de viver; não, a desesperança consiste em que mesmo a última esperança, a morte, não chega. Quando a morte é o maior dos perigos, espera-se viver; mas quando se toma conhecimento do perigo ainda mais assustador, coloca-se a esperança na morte." Adorno, Kierkegaard. 
isso sem falar no pressuposto não-dialético de que seria possível uma economia não antagonista em uma sociedade antagonista. ${ }^{109}$

A respiração artificial que garante a sobrevida do capitalismo, que impede que a crise seja um momento de decisão entre morte e vida, já havia se tornado estrutural. $\mathrm{O}$ elemento de obsolescência do capitalismo inverte-se naquilo que o mantém. Quando Adorno tentou delinear o "capitalismo tardio", notou essa obsolescência das relações de produção, que não só são ultrapassadas pelas forças produtivas, como deveriam ser arrebentadas por esta, segundo a predição de Marx. Entretanto, as relações de produção ganham uma espécie de onipotência negativa, isto é, elas tornam-se intransponíveis justamente em seu caráter objetivamente anacrônico.

O poder das relações de produção, que não foram revolucionadas [umgewälzt], é maior do que nunca, mas, ao mesmo tempo, elas são objetivamente anacrônicas, estão por toda parte adoecidas, danificadas, perfuradas. Elas não funcionam mais de forma automática [selbsttätig]. O intervencionismo econômico não é enxertado de forma estranha ao sistema, como pensa a velha escola liberal. Ele é imanente ao sistema, a quintessência [Inbegriff] da autodefesa; nada poderia esclarecer o conceito de dialética de forma mais contundente. ${ }^{110}$

Em diversas passagens, Adorno afirma que Marx havia sido muito otimista em relação ao desenvolvimento das forças produtivas com a expectativa de que elas iriam romper as relações de produção (e acabaram assumindo um teor positivo). Nesse aspecto, Adorno via efetivamente uma anulação da dialética entre forças produtivas e relações de produção (Marcuse falava de uma simbiose entre as duas): "A marca dessa era é a preponderância das relações de produção sobre as forças produtivas, que no entanto há muito tempo zombam das relações de produção."111 É provável que esse novo “intervencionismo econômico", fenômeno generalizado, fosse o cimento dessa simbiose. No espectro político do pós-guerra, a ideia de economia planejada não era exclusividade

${ }^{109}$ Adorno; Horkheimer, Briefe, p. 139-140. E continua: "Eu prevejo uma situação realmente aporética. Se o artigo é publicado nessa ou em uma versão semelhante, então ela apenas provocaria danos à reputação do Instituto, mas, sobretudo, à de Fritz [Pollock], e liberaria o alarido triunfante de todos os Löwe, Neumann e tutti quanti. Mas se ele não for publicado, então isso seria uma derrota grave para o número [da Revista] sobre o capitalismo de Estado, pois nem precisamos falar do que se pode esperar do artigo de Neumann, inspirado por Lynd, sobre a possibilidade de um capitalismo de Estado democrático". (Trad.: Luiz de Caux e Amaro Fleck).

${ }_{110}$ Adorno, "Spätkapitalismus oder Industriegesellschaft", p. 367.

${ }^{111}$ Idem, p. 363. 
nem da economia de comando socialista do bloco soviético nem da esquerda ocidental social democrata, de forma que, como lembra Hobsbawm, "um estadista americano de férreas credenciais capitalistas - Averrel Harriman - [disse] a seus compatriotas, em 1946: ‘As pessoas deste país não têm mais medo de palavras como 'planejamento' [...], as pessoas aceitaram o fato de que o governo tem de planejar tanto quanto os indivíduos deste país." "112 Aos poucos, termos como "liberalismo social", "capitalismo de Estado", "economia planejada" deixaram de soar como oxímoros no ouvido das pessoas. Havia algo que parecia ser não-capitalista no capitalismo, algo que parecia alheio ao sistema. Nesse ponto Adorno insistia que aquilo que parecia ser algo de fora era na verdade o próprio âmago da coisa: "O que é estranho ao sistema [das Systemfremde] revela-se como constituinte do sistema." ${ }^{113}$ Quando Adorno proferiu sua palestra "Capitalismo tardio ou sociedade industrial" em um congresso de sociologia, ainda estava no ar a questão se aquela sociedade na qual viviam ainda era capitalista. Ele insistia de forma didática: "A sociedade é sociedade industrial de acordo com suas forças produtivas. [...] Por outro lado, a sociedade é capitalismo em suas relações de produção." 114

Por fim, Adorno era avesso a um certo weberianismo da tese pollockiana, segundo a qual o processo de racionalização social dominaria todas as esferas, inclusive a econômica. Em oposição a isso, Adorno gostava da expressão "anarquia da produção de mercadorias" de Marx. Ou seja, o capitalismo é, no fundo, uma bagunça. Por um lado, trata-se efetivamente de uma sociedade que se tornou completamente "socializada", isto é, uma sociedade que se tornou totalidade, completamente mediada pela forma da mercadoria, totalmente administrada. Por outro lado, o núcleo que lhe dá sentido, isso é, a produção de mercadorias, permanece uma desrazão. Adorno faz isso, no entanto, sem ter como horizonte o planejamento e a realização desse processo de racionalização social: “tal planejamento racional está, de acordo com sua própria essência, vinculado à dominação." 115 Tanto no bloco soviético quando no mundo ocidental havia uma convergência entre economia planificada e desrazão objetiva do valor que se autovaloriza, entre burocracia e capitalismo. Como disse o próprio Adorno em conversa com Horkheimer: "O mundo não é só louco. Ele é louco e racional.",116

\footnotetext{
${ }^{112}$ Hobsbawm, Era dos Extremos, p. 268.

${ }^{113}$ Adorno, "Spätkapitalismus oder Industriegesellschaft", p. 368.

${ }^{114}$ Adorno, "Spätkapitalismus oder Industriegesellschaft", p. 361.

${ }_{115}$ Adorno, Vorlesung - Fragen der Dialektik, Aula de 28/01/1964, TWAA.

${ }^{116}$ HGS 19, p. 47.
} 


\section{A bomba, os russos e os americanos}

A verdade é que me recuso a admitir a forçosa alternativa do binômio sinistro: Rússia - Estados Unidos. Se não houvesse possibilidade de salvação fora da opressão comunista ou do imperialismo norte-americano, então seria melhor que este mundo se espatifasse sob o poder das bombas de hidrogênio das duas facções.

Manuel Bandeira, Entrevista, 1952

Retorno ao ponto em que é necessário lembrar que o mundo pós-1945 é o mundo depois de Hiroshima e Nagasaki. É o mundo em que, nas palavras de Gumbrecht, "a imagem do suicídio coletivo de um país - estendido a toda a Humanidade - transformouse numa possibilidade material ao alcance da tecnologia, e isso o mundo não poderá esquecer." ${ }^{117}$ As imagens progressistas da história vinham se desfazendo desde a Primeira Guerra Mundial, e isso se radicalizou ao se constatar que a mesma coisa que aumentava o poderio da humanidade, a saber, o progresso técnico, tinha dado à humanidade uma onipotência negativa, que incluía o poder de se auto-aniquilar: era o sinal definitivo de que se tratava de uma nova época - uma época que, paradoxalmente, voltava a cultivar de forma dúbia projeções progressistas. Afinal, o progresso agora ganhava um sentido puramente de evitação, como notava Adorno: "Hoje, tais reflexões [sobre o progresso] culminam na consideração sobre se a humanidade será capaz de evitar a catástrofe." De todo modo, trata-se de uma época que, para Günther Anders, sequer poderia ainda ser chamada de "época", pois como ela é a última (se a bomba é impossível de ser desinventada, a era nuclear é intransponível), ela é considerada um prazo.

A época das mudanças de época está terminada desde 1945. Daqui em diante vivemos em uma era que não é mais uma época passageira antes de outras, mas um "prazo", durante o qual nosso ser não é nada mais que ininterruptamente um "ser-por-pouco" [Gerade-noch-sein]. A obsolescência [Obsoletheit] de Ernst Bloch, que relutou mesmo em tomar conhecimento do acontecimento de Hiroshima, consistiu em sua crença levada quase por inércia de que nós viveríamos ainda em um "aindanão", isto é: em uma "pré-história" precedente à verdadeira $[\mathrm{dem}$

\footnotetext{
${ }^{117}$ Continua ele: "Sabemos - mais até pelos rostos imortalizados num punhado de fotos do que pelas palavras dos sobreviventes - que as mulheres e os homens que viveram aqueles momentos em Hiroshima acreditaram que tinha chegado o início do fim do mundo. Nunca haverá futuro suficiente para provar-lhes o contrário." Gumbrecht, Depois de 1945, p. 36-37.

${ }^{118}$ Adorno, "Progresso", p. 38.
} 
Eigentlichen]. Ele não conseguiu se esforçar em não ter esperança [nicht hoffen] por um momento que seja. ${ }^{119}$

A difusão do termo "era atômica" era prova de que se adentrava, de fato, uma outra era - fato determinante para as mais diferentes esferas, inclusive, aliás, o direito. Um respeitável cientista político da Universidade de Cornell, e não um filósofo alemão exagerado, afirmou em seu livro Constitutional Dictatorship, de 1948: "It is not too much to say that the destiny of this nation in the Atomic Age will rest in the capacity of the Presidency as an institution of constitutional dictatorship. In the Atomic Age upon which the world is now entering, the use of constitutional emergency powers may well become the rule and not the exception." ${ }^{120}$ Uma possível guerra nuclear certamente não se configura do mesmo modo como uma guerra tradicional - e isso altera a configuração do Estado que, diante da possibilidade de uma guerra nuclear, deve poder reduzir todo o aparato jurídico e estatal aos plenos poderes do presidente e seu botão vermelho. Como nota Marcuse, a ameaça da catástrofe nuclear é aquilo que protege as forças que perpetuam o perigo. ${ }^{121}$

Se Günther Anders, impactado pela dimensão do que significava a era nuclear, transformou a bomba atômica em objeto filosófico ao qual dedicou imensamente sua energia intelectual e política ${ }^{122}$, nos escritos de Adorno a bomba raramente aparece de

${ }^{119}$ Günther Anders, Die Antiquiertheit des Menschen II, cit., p. 20. As inversões provocativas de Bloch são uma constante nos textos de Anders: a Zeitenwende [mudança dos tempos/mudança de época] e a Wendezeit [tempo das mudanças] de Bloch tornam-se, no título de um livro seu sobre a ameaça nuclear, Endezeit e Zeitenende [tempo do fim e fim dos tempos]. Em outro livro, que reúne reações públicas a uma entrevista de Anders na qual ele defende a necessidade de ação política violenta e diz que "a esperança só é outra palavra para covardia", há o seguinte comentário de dois jovens autores: "Não nos tome nosso Bloch, Günther Anders! A nossa esperança beletrista agaloada. [...] Não há mais como salvar Bloch, isso nós sabemos. E mesmo assim nós precisamos dele como espírito de vida [Lebenssprit] e doador de ânimo [Atemgeber], pois nós temos ainda esperamos - uma vida pela frente, temos somente 35 anos e não já 85." Anders, Gewalt - Ja oder nein?, cit., p. 52. Na era da obsolescência da esperança, para Anders, a paciência já não é mais considerada uma virtude. Apesar de tais passagens duras, Anders dedica seu livro Der Blick vom Mond a Bloch, "com amizade e admiração".

${ }^{120}$ Clinton Rossiter, Constitutional Dictatorship: Crisis Government in the Modern Democracies. Princeton University Press: Princeton, 1948, p. 297. Rossiter é um dos autores analisados por Agamben em seu Estado de Exceção - agradeço a Paulo Arantes pela referência.

${ }_{121}$ Assim começa Marcuse seu One-Dimensional Man: "Does not the threat of an atomic catastrophe which could wipe out the human race also serve to protect the very forces which perpetuate this danger? [...] If we attempt to relate the causes of the danger to the way in which society is organized and organizes its members, we are immediately confronted with the fact that advanced industrial society becomes richer, bigger, and better as it perpetuates the danger." Marcuse, One-Dimensional Man, p. xxxix-xl.

${ }^{122}$ Como Günther Anders, que escreveu sobre a responsabilidade diante da existência da bomba, Sartre escreveu no final da guerra: "[...] essa pequena bomba que pode matar cem mil homens de 
forma direta, somente de forma lateral. Em uma carta a Günther Anders, Adorno justifica: "Eu sempre evitei escrever sobre a bomba atômica por um motivo que não é muito simples de compreender, talvez por causa da desproporção entre o punho cerrado de um intelectual e aquele dispositivo [Einrichtung], certamente não por covardia." ${ }^{\text {"123 }}$ Isso não significa, para Adorno, uma diminuição da dimensão da bomba e seu efeito sobre a realidade contemporânea, pelo contrário. Em suas "Notas marginais sobre teoria e práxis", é a existência da bomba que reduz um certo tipo de política, outrora potencialmente revolucionária, a teatro: "Contra os que administram a bomba, são ridículas as barricadas; por isso, brinca-se de barricadas e os donos do poder toleram temporariamente os que estão brincando." ${ }^{124}$ A brutalidade e o anti-idealismo político dessa frase é digna de um Carl Schmitt, que, aliás, diz coisa muito semelhante acerca da assimetria de poder produzida pelo desenvolvimento tecnológico (tão semelhante que nos faz especular se se trata de uma referência direta de Adorno a Schmitt): “As imagens tradicionais de marchas de rua, barricadas etc. aparecem como brincadeira de criança frente a esses instrumentos de poder modernos." "125 A observação mais problemática de Adorno, contudo, a respeito da bomba atômica, encontra-se em um texto que é na verdade uma nota, assinada junto com Horkheimer, intitulada "A URSS e a paz", em que eles respondem a um chamado de um grupo de pacifistas da universidade contra os armamentos nucleares:

É evidente que o desenvolvimento da paz é hoje o desejo mais urgente de todas as pessoas, e que as novas armas podem ocasionar a catástrofe definitiva. Mas é uma expressão da situação enleada [verstrickt] e ofuscada, que força para aquele

um só golpe, e que amanhã matará dois milhões, ela nos coloca de repente diante de nossas responsabilidades. Da próxima vez, a Terra pode explodir: esse fim absurdo deixaria em suspenso para sempre os problemas que, há dez mil anos, constituem nossas preocupações." Sartre, "La fin de la guerre", in Situations III, p. 68.

${ }^{123}$ Briefe Adorno-Anders, TWAA.

${ }^{124}$ Adorno, "Notas marginais sobre teoria e práxis, p. 217

${ }^{125}$ É nesse contexto que Schmitt escreve essa frase: "Estamos todos sob a impressão de um violento aumento de poder de todo Estado hoje por meio do melhoramento da técnica, mais especificamente, dos instrumentos de poder [Machtmittel] técnico-militares. Os meios técnicos modernos conferem também a um pequeno Estado e seu governo um tal poder e eficácia, que, comparativamente, tornam-se pálidas as velhas representações tanto do poder estatal como da resistência contra ele. As imagens tradicionais de marchas de rua, barricadas etc. aparecem como brincadeira de criança frente a esses instrumentos de poder modernos. Todo Estado é coagido a assumir o controle das novas armas. Se ele não tem a força e a coragem para isso, então um outro poder ou outra organização assumirá o controle, e então ele será o Estado." Carl Schmitt, "Starker Staat und gesunde Wirtschaft" in Staat, Großraum, Nomos. Arbeiten aus den Jaren 1916-1969. p. 73-74. Agradeço a Giovanni Zanotti pela referência. 
horror absoluto, que a verdade ainda corre o risco de ser invertida em mentira, na medida em que ela é usada a serviço da mentira. Apelo à paz e ostracização das armas nucleares são um momento da propaganda soviética, que visa em toda parte tirar proveito das emoções humanas, de forma que seja quebrada a resistência contra o poder [Gewalt] que emana da União Soviética e que não irá hesitar em desencadear a guerra quando os poderosos [Gewaltherrscher] de Moscou acreditarem que podem ganhá-la. A demanda por paz, compartilhada pelos povos de todos os países, é utilizada para que a nova empresa totalitária ganhe tempo. $^{126}$

Nesse trecho, Adorno e Horkheimer parecem reproduzir algo da paranoia antisoviética estimulada do lado ocidental da cortina de ferro, uma paranoia que visava construir legitimidade na opinião pública para a corrida nuclear que se desenrolava. Não sabemos se a voz dominante aqui é de Horkheimer, que escreveu também em um fragmento intitulado "O futuro da Europa", cujo destino, anunciava ele de forma pessimista, era o autoritarismo: "Sem exaltação e forças armadas, sem milagre econômico e rearmamento, Moscou teria tomado a Alemanha ocidental há muito tempo."127

Claude Eatherly, o piloto de Hiroshima que se tornou posteriormente um pacifista engajado e que se correspondia com Günther Anders, era acusado nos Estados Unidos de ser pró-Stalin e de influenciar as eleições - lembremos que tanto o anticomunismo quanto o militarismo tinham importante função eleitoral e eram fortes determinantes da política interna americana. ${ }^{128}$ De todo modo, é possível dizer que, mantendo aquela divisão em dois que Habermas fez de Adorno, há de um lado o crítico radical do capitalismo e de suas formas culturais e políticas (que, de forma "meta-crítica", engloba a União Soviética), e de outro o Volkspädagog, um social-democrata mais por prudência do que por convicção, pois no fundo sabia-se muito bem a farsa daquele jogo de cena - embora fosse necessária uma atitude de precaução em relação aos perigos da recaída no fascismo, ao mesmo tempo em que era intolerável um alinhamento ao horror da sociedade de mobilização total soviética. Nesse contexto, Adorno nutria até mesmo uma simpatia, apesar de tudo, pelos Estados Unidos. Ao mesmo tempo em que Adorno

\footnotetext{
${ }^{126}$ Adorno, "Die UdSSR und der Frieden" in: GS 20.1, p. 390.

${ }^{127}$ Horkheimer, "Nachgelassene Notizen 1949-1969", HGS 14, p. 113.

128 "A cruzada contra o 'Império do Mal' a que - pelo menos em público - o governo do presidente Reagan dedicou suas energias destinava-se assim a agir mais como uma terapia para os EUA do que como uma tentativa prática de reestabelecer o equilíbrio de poder mundial." Hobsbawm, Era dos Extremos, p. 245. Também McCarthy havia descoberto "o potencial político da denúncia em massa do inimigo interno". Ibid, p. 232.
} 
se debruçava com acidez crítica (e até repulsa) sobre as patologias da sociedade americana nos seus aspectos mais diversos (algo bastante evidente tanto na Dialética do Esclarecimento quanto na Minima Moralia ${ }^{129}$, ambos escritos durante o exílio), ele, enquanto judeu que havia fugido da velha Europa em chamas, não deixou de sentir uma lufada de ar fresco no novo mundo ${ }^{130}$. Em vários momentos, Adorno indica que nos EUA haveria uma cultura democrática mais enraizada que nos países europeus. Os breves comentários de Adorno sobre a democracia americana parecem surgir menos de uma análise detida de suas estruturas políticas e sociais, mas muito mais de uma impressão que parte da experiência vivida, um sentimento filosófico do clima espiritual e histórico - de forma semelhante a Benjamin em suas anotações de viagem. Há um encantamento de viajante tanto nos comentários de Benjamin sobre a União Soviética, da época de sua viagem a Moscou, quanto nas referências de Adorno ao enraizamento das experiências democráticas na vida norte-americana, tendo sempre a terrível Alemanha como medida de comparação. Retomando suas experiências no exílio, Adorno escreve:

Foi mais essencial e proporcionou-me mais felicidade a minha experiência da substancialidade das formas democráticas: o fato de que elas estão infiltradas na vida norte-americana, enquanto que, na Alemanha, nunca foram mais do que regras de jogo formais e, segundo temo, ainda não são mais do que isso. Ali conheci um potencial de humanidade real, como quase não existe na velha Europa. A forma política da democracia está infinitamente mais próxima das pessoas. É próprio da vida norteamericana, apesar da pressa tão deplorada, um momento de amenidade, benignidade e grandiosidade, que é o extremo oposto da maldade represada e da inveja represada que explodiu na Alemanha entre os anos 1935 e $1945 .^{131}$

A oposição entre o ar utópico da modernidade americana e a deformação histórica alemã aparece em outros momentos, o que contradiz certa imagem (estado-unidense, por

\footnotetext{
${ }^{129} \mathrm{O}$ próprio emprego de termos em inglês tem, muitas vezes, uma função irônica e crítica em relação a reificações na linguagem do business, inseparáveis do "mundo da vida" norteamericano, com suas formas culturais particulares específicas, e do próprio capitalismo.

${ }^{130}$ Também Sartre, ao escrever sobre as cidades americanas, encontrou ali uma sociedade orientada para o futuro, diversamente de uma Europa carregada de passado: "Une ville, pour nous, c'est d'abord un passé; pour eux, c'est d'abord un avenir, ce qu'ils aiment en elle, c'est tout ce qu'elle n'est pas encore et tout ce qu'elle peut être." Sartre, "Villes d'Amérique", Situations, III, p. 101.

${ }^{131}$ Adorno, "Experiências científicas nos Estados Unidos", p. 174 (tradução modificada).
} 
certo) de um Adorno excessivamente europeu. ${ }^{132}$ Por exemplo, no texto "Individuum und Staat", ele observa que na Alemanha nunca se realizou uma identidade entre Estado e Povo (que seria, por fim, uma espécie de dissolução do Estado, em que o Estado deixaria de ser sentido enquanto algo outro, em oposição ao indivíduo), enquanto nos Estados Unidos o Estado seria sentido de forma mais amena, menos opressiva (a ideia insinuada de uma identidade realizada dificilmente poderia ser desenvolvida seriamente, tendo em vista tanto o macartismo quanto os desdobramentos contemporâneos do que se tornou o Estado norte-americano como um Estado altamente militarizado):

O povo alemão nunca se viu como idêntico ao próprio Estado. $\mathrm{O}$ Estado sempre foi visto na melhor das hipóteses como um poder benevolente, porém muito mais como um poder ameaçador, cobrador de impostos, fazedor de guerras, de todo modo um poder estranho [fremde]. Com efeito, no período do crescimento industrial, havia todo tipo de vantagens, porém esperava-se somente o negativo do Estado, mesmo quando não se pertencia às camadas que viviam em conflito imediato com o poder do Estado. Talvez em nenhum outro aspecto a diferença entre o clima político na América e na Alemanha seja tão perceptível como nesse. Pois o Estado americano é sentido de fato por seus cidadãos como uma forma de organização social, mas nunca como uma autoridade que paira sobre a vida dos indivíduos, como uma autoridade mandante ou mesmo absoluta. [...] A ausência de um tal fetichismo do Estado nos países anglo-saxões, mas sobretudo justamente na América, torna a relação do indivíduo com o Estado muito mais fácil. Se lá, como em toda parte, grandes partes da população se defrontam com o Estado de forma indiferente, então eles não têm o sentimento de que o Estado é algo completamente outro do que eles mesmos, algo fora deles, um ser em si, e que teria que comandá-los de forma despótica. ${ }^{133}$

De forma distinta dos Estados Unidos, há na Alemanha uma identificação patológica entre essas duas instâncias que são radicalmente separadas (indivíduo e Estado): "Na Alemanha, porém, as massas podiam eventualmente identificar-se com o

\footnotetext{
${ }^{132}$ Até mesmo aquilo que produziria o vínculo forte entre Adorno e a Europa, a saber, a ideia de "cultura" e "espírito", foi algo cuja relativização na experiência norte-americana teve seu valor educativo, daí sua "gratidão intelectual" frente a esse país: "Nos Estados Unidos, libertei-me da ingênua credulidade cultural, adquiri a capacidade de ver a cultura desde o lado de fora. Eu explico: apesar de toda minha crítica social, e pese a que tinha consciência do predomínio da economia, desde sempre tive por evidente a absoluta relevância do espírito. Que essa evidência não é válida assim sem mais, vim a aprender na América, onde não impera qualquer respeito tácito pelo espiritual, como no centro e no ocidente da Europa, em setores que vão além da denominada classe culta; a ausência desse respeito leva o espírito à consciência crítica de si mesmo."Adorno, "Experiências científicas nos Estados Unidos", p. 173-4

${ }^{133}$ Adorno, "Individuum und Staat", p. 291.
} 
Estado como com um pai forte e tirânico. Mas elas nunca foram idênticas a ele. Justamente a jamais superada consciência de estranheza [Fremdheit] para com o Estado levou então à exacerbação obstinada da crença no Estado sob o regime autoritário." "134 Apesar de todos os seus estudos sobre os potenciais fascistas internos à sociedade americana, para Adorno "[...] a força de resistência contra as correntes fascistas é maior nos Estados Unidos que em qualquer país europeu, com a exceção, talvez, da Inglaterra [...]." ${ }^{135}$ A americofilia de uma geração inteira da esquerda alemã (e que ressoa ainda hoje) está ligada à significativa contribuição dos Estados Unidos para a derrota militar do nazi-fascismo na Europa. Por isso, diferentemente de lugares periféricos como a América Latina, onde o anti-americanismo tem um caráter anti-imperialista e de afirmação das soberanias e identidades nacionais (o que não tem a ver, a princípio, com anticapitalismo), o anti-americanismo aparece na Alemanha como o ressentimento dos perdedores. Por isso, Horkheimer diz (também aqui na caneta de Pollock):

\begin{abstract}
A América salvou a Europa da completa escravidão. A resposta é hoje em toda parte, não somente na Alemanha, uma profunda e disseminada hostilidade aos Estados Unidos. [...] Surpreendente é a circunstância em que onde há anti-americanismo, espalha-se também o antissemitismo. O mal-estar geral, condicionado pelo declínio da cultura, busca um culpado, e pelos motivos citados acima, entre outros, ele encontra os americanos, e na América, os judeus, como sempre, que supostamente dominam os Estados Unidos. ${ }^{136}$
\end{abstract}

Mas não custa lembrar que a posição de Horkheimer e de Adorno não eram a mesma, principalmente a partir dos anos 1950, quando Horkheimer passou a assumir uma posição decididamente mais conservadora (que marca, segundo comentadores, sua passagem do marxismo a um pessimismo metafísico schopenhaueriano - embora tal schopenhauerianismo, como mostrou Alfred Schmidt em vários de seus trabalhos, tenha também uma função crítica). Mas o anti-comunismo de Horkheimer era algo que se fazia efetivamente presente. Em uma conversa entre os dois, Horkheimer diz, sobre o fato de na Alemanha, aos olhos do povo, os Estados Unidos parecerem suspeitos e a Rússia não: “Os russos já são metade fascistas.” Ao que Adorno responde: "Se o coração dos alemães

\footnotetext{
${ }^{134}$ Adorno, "Individuum und Staat", p. 291

${ }_{135}$ Adorno, "Experiências científicas nos Estados Unidos", p. 175.

${ }^{136}$ Horkheimer, "Späne", p. 408.
} 
batem pelos russos, isso não é somente negativo. Eles acreditam que os russos defendem o socialismo. [...] Sobre os americanos, eles acham que é tudo só dinheiro."137

\section{A latência e o manifesto: o "leninismo" de Adorno}

A ética, aplicada à história, é a doutrina da Revolução.

Walter Benjamin

A New Left Review e a editora Verso deram vida própria a um registro de discussões entre Adorno e Horkheimer de 1956, publicado originalmente como "Diskussion über Theorie und Praxis", ao traduzirem com o título chamativo Towards a new manifesto. ${ }^{138}$ Nessa discussão, Adorno fala sobre a necessidade e a intenção de escrever uma nova versão do Manifesto Comunista, um "manifesto estritamente leninista". Dois anos depois dessa publicação, foi publicado em um jornal alternativo de esquerda alemão, o Jungle World, um curioso artigo intitulado Adornos Leninismus: Kritische Theorie und das Problem der Avantgarde. ${ }^{139}$ Apesar de sua oposição à União Soviética, seria Adorno, afinal, um leninista? É possível, efetivamente, traçar uma recepção adorniana de Lenin, como o faz o próprio autor do artigo. Nota-se que, por um lado, Adorno se dedica de forma mais detida à leitura de Lenin nos anos 1930, durante os anos da ascenção hitlerista. Em uma carta a Horkheimer de 1936, Adorno refere-se a Erich Fromm como "sentimental e falsamente imediatista, uma mistura de socialdemocracia e anarquismo." Mais adiante: "Ele se desfaz muito facilmente do conceito de autoridade, sem o qual nem a vanguarda nem a ditadura de Lenin poderia ser pensada. Eu o aconselharia urgentemente a ler Lenin." ${ }^{140}$ Em uma outra carta a Walter Benjamin, ele escreve que seu ensaio "A obra de arte na era de sua reprodutibilidade técnica" contém

137 "Horkheimer: Os russos já são metade fascistas. Adorno: Se o coração dos alemães batem pelos russos, isso não é só negativo. Eles acreditam que os russos defendem o socialismo. [..] Sobre os americanos, eles acham que se trata tudo de dinheiro."Adorno; Horkheimer, "Diskussion über Theorie und Praxis", HGS 19, p. 56.

${ }^{138}$ Não teve a mesma felicidade a tradução feita no Brasil, publicada na revista Serrote, em que o texto ganhou o título de "Um atrapalho no trabalho", que é, originalmente, o título de um livro do John Lennon em português.

${ }^{139}$ Lars Quadfasel, "Adornos Leninismus: Kritische Theorie und das Problem der Avantgarde" in Jungle World, disponível em: https://jungle.world/artikel/2013/21/adornos-leninismus (Acesso: 12/12/2018).

${ }^{140}$ Carta de Adorno a Horkheimer, 21/03/1936. 
frases "as mais profundas e potentes no que concerne a teoria política que encontrei desde que eu li Estado e Revolução."141

Já nos anos 1950, Adorno ensaia duas vezes a radicalidade política, mas não chega a entrar em cena. Para além desse projeto de um "manifesto estritamente leninista", que deveria ser escrito aos moldes do Manifesto Comunista, Adorno planeja escrever uma crítica do novo programa do partido social-democrata (SPD), o Programa de Godesberg, também inspirado na crítica de intervenção marxiana, desta vez na Crítica do Programa de Gotha. Sua intenção era ao mesmo tempo fazer oposição a Adenauer e à guinada conservadora do SPD, que aderia inclusive ao discurso da parceria social ${ }^{142} \mathrm{e}$ abandonava de uma vez por todas qualquer perspectiva socialista, aceitando a economia de mercado como definitiva. Entretanto, Adorno entendia que, na frágil civilização reconstruída, que mantinha em si ainda presente todo o potencial destrutivo da barbárie, uma ação errada poderia contribuir para antecipar a queda que deveria, a todo custo, ser evitada. Adorno evoca mesmo um "sentimento de responsabilidade", que se exprimia como extrema prudência e cautela diante de um mundo que é, a rigor, uma bombarelógio. Em uma carta a Enzensberger: "Eu não sei se agora é o melhor momento para acertar as contas com os rumos do SPD. O perigo do neonazismo na Alemanha é muito agudo para isso. [...] Agora me parece mais importante evitar tudo que possa, mesmo indiretamente, contribuir para um fortalecimento do radicalismo de direita. [...] Eu espero que você não veja aí a expressão de oportunismo, mas sim do mais simples sentimento de responsabilidade." $" 143$

A impressão de que para os frankfurtianos evitar a barbárie significa, na melhor das hipóteses, agir com muita prudência, não é descabida. Afinal, aquilo que é mais latente, e que está sempre no limite de tornar-se manifesto, é o horror. Entretanto, Adorno tinha consciência, ao mesmo tempo, de que só havia uma forma de efetivamente barrar o fascismo: a transformação social radical, em suma, a revolução, ao mesmo tempo em que não havia mais nem sombra de potenciais revolucionários durante o pós-guerra. Referindo-se à inteligência de Lenin, contudo, Adorno escreve (durante os anos 30) que a revolução não é meramente um ato máximo de força, mas um ponto de virada a partir do qual, com uma força mínima, é possível derrubar um poder descomunal. Adorno

\footnotetext{
${ }^{141}$ Carta de Adorno a Benjamin, 18/03/1936.

142 "Horkheimer: Para isso, agora fala-se de parceiros sociais. Adorno: Todas as oposições são colocadas no mesmo saco." "Diskussion über Theorie und Praxis", p. 43.

${ }^{143} \mathrm{Br} 361 / 27$, TWAA.
} 
chamou isso de "O ponto da alavanca", que é o título de um fragmento escrito alguns anos antes da guerra estourar, no qual ele diz: "Aprender de Lenin: [...] sua capacidade de descobrir o ponto da alavanca social [den gesellschaftlichen Hebelpunkt] e usá-lo: com a força mínima, erguer o peso imenso do Estado. [...] O destino da classe trabalhadora alemã, e talvez o da humanidade, dependerá da capacidade de encontrar esse ponto, e somente onde ele deve ser encontrado: no sistema fascista. Não há nenhuma outra esperança de que a guerra seja evitada, senão essa." "144 Esse é o ponto preciso em que a força do adversário (ou seja, a força que oprime) é utilizada contra ele mesmo, de modo que, com uma artimanha dialética, a força muda de sinal. ${ }^{145}$ Saber encontrar esse ponto significa encontrar aquilo que Marx chamou de "elemento passivo" das revoluções, a "base material"146 que serve de apoio para a alavanca. ${ }^{147}$ Essa alavanca, importante lembrar, já não era pensada como uma catapulta para o futuro, visto que a locomotiva da história se mostrava ser a própria expressão da desrazão objetiva do mundo ao conduzir a humanidade para o abismo - Adorno assimilou a crítica ao progresso de Benjamin, para quem a revolução não era nenhum salto adiante, mas sim o freio de emergência que deveria vir embutido na maquinaria destrutiva do capitalismo. Desde a alternativa dramática anunciada por Rosa Luxemburgo - "socialismo ou barbárie" - podemos dizer que as esperanças revolucionárias não se vinculam à promessa de realizar o paraíso na Terra, mas à possibilidade e ao imperativo de sobrevivência da humanidade. Se o jovem Marx via a Revolução como a realização da filosofia (motivo, aliás, ao qual Adorno se mantém fiel e que é anunciado na célebre primeira frase da Dialética Negativa ${ }^{148}$ ) e

\footnotetext{
${ }^{144}$ Cf. Adorno - eine Bildmonographie.

${ }^{145} \mathrm{Tal}$ concepção é análoga à própria ideia de crítica dialética, que faz o objeto se destruir a partir de si. Também Hegel fala sobre encontrar a "força do adversário": "A verdadeira refutação tem de penetrar na força do oponente e se colocar no âmbito de abrangência de sua força; atacá-lo fora dele mesmo e manter razão onde ele não está presente, isso não avança a coisa [Sache]." Hegel, Wisssenschaft der Logik, p. 553.

146 "Revoluções precisam de um elemento passivo, uma base material." Marx, MEW 1, p. 386.

${ }^{147}$ Quando Adorno escreve depois na Minima Moralia que não havia nenhuma "fenda na rocha do existente" onde o irônico pudesse se apoiar, ele apontava ao mesmo tempo os impasses da crítica imanente da ideologia quanto a dificuldade de encontrar o tal "ponto da alavanca", isto é, algo no interior (da totalidade social) onde se possa apoiar para poder sair.

148 "A filosofia, que um dia pareceu ultrapassada, mantém-se viva porque se perdeu o instante de sua realização." DN, p. 11. Tal frase foi interpretada como um habeas corpus para se ficar filosofando para sempre, ao passo que ela significa, na verdade, que a tarefa de realizar a filosofia se mantém atual, uma vez a realidade permanece uma realidade "não-reconciliada", isto é, uma realidade ruim.
} 
esperava unir "o coração e a cabeça"149 da Alemanha - no caso, o proletariado e a fillosofia - também Adorno via a necessidade de uma "união dos extremos", a saber, a união entre os intelectuais e as massas, da qual dependeria nada menos, justamente, que a sobrevivência do humanidade:

Os trabalhadores enganados dependem diretamente daqueles que ainda conseguem enxergar alguma coisa e falar-lhes de seu engano. Seu ódio pelos intelectuais sofreu uma mudança correspondente. Alinhou-se com as opiniões correntes do senso comum. As massas já não desconfiam dos intelectuais por eles traírem a revolução, mas porque eles talvez a queiram; com isso, relevam quão grande é sua própria necessidade de intelectuais. A humanidade só sobreviverá se os extremos se unirem. ${ }^{150}$

O que mantém a revolução como possibilidade é, no limite, a própria ideia de contradição. Como dizia Brecht, que tinha um senso atinado para a dialética, "as contradições são nossa esperança". Ou seja, a insistência na ideia de dialética e de contradição (isto é, que a sociedade permanece um todo contraditório) significa uma insistência na possibilidade estrutural de uma mudança radical, mesmo que ela não seja algo imediatamente visível e ao alcance da mão. Insistir na ideia de dialética significa, como o próprio Adorno diz, que "contraforças objetivas" possam ser liberadas a partir das contradições imanentes:

Meu sentimento mais íntimo sobre isso é: no momento tudo está fechado, mas a todo momento isso pode mudar. Eu faço a seguinte consideração: essa sociedade não se move em direção a um Estado de Bem-Estar. [...] Eu não consigo imaginar que exista um mundo intensificado a tal ponto de delírio, sem que contraforças objetivas sejam liberadas. ${ }^{151}$

Antes de o welfare state acabar, Adorno antevia seu fim, assim como o potencial fascista de uma sociedade que, em sua integração máxima, tendia à desintegração. ${ }^{152} \mathrm{O}$ mundo do pós-guerra, das contradições reguladas, não poderia perdurar na sua fachada de pacificação. Se uma coisa era sabida, era que "a recaída na barbárie é sempre uma

\footnotetext{
149 “A cabeça dessa emancipação é a filosofia, seu coração o proletariado. A filosofia não pode se realizar sem a suprassunção [Aufhebung] do proletariado, o proletariado não pode se suprassumir [aufheben] sem a realização da filosofia." Marx, MEW 1, p. 291.

${ }_{150}$ Adorno, Minima Moralia, GS 4, p. 302 (tradução em Um mapa da ideologia, p. 50).

${ }^{151}$ HGS 19, p. 47.

${ }^{152}$ A palestra "Aspectos do novo radicalismo de direita", proferida em 1967, vista a partir do presente, soa impressionantemente profética e precisa no diagnóstico. Adorno, Aspekte des neuen Rechtsradikalismus - Ein Vortrag. Frankfurt am Main: Suhrkamp, 2019.
} 
opção" ${ }^{\text {"153 }}$, e não há dialética que, por si só, corrija os rumos da humanidade. Entretanto, é necessário pensar, no mínimo, que tal recaída não seja um destino inexorável.

${ }^{153}$ Ibid. 


\section{Capítulo 2 - Dimensão prático-moral do conceito enfático de verdade}

There is an essential connection between freedom and truth, and any misconception of truth is, at the same time, a misconception of freedom. Herbert Marcuse, Espólio, 1939

\section{O mundo é falso: imaginação e verdade}

Quando não se tem imaginação, morrer não é nada; quando se tem, morrer é demais. Louis-Ferdinand Céline, Viagem ao fim da noite

O espírito utópico pressupõe um distanciamento da realidade imediata, pois deseja algo que não existe. Certos autores da assim chamada teoria crítica buscaram trabalhar com um conceito de verdade que correspondesse à exigência de ser contra o existente. Um ímpeto certamente vanguardista, na esteira do expressionismo ${ }^{154}$, pois, como dizia

\footnotetext{
${ }^{154}$ A relação entre as origens da teoria crítica e o expressionismo, cuja marca permanece ainda nas obras tardias de Adorno, não é casual e mereceria uma pesquisa à parte. Hartmut Scheible diz que Geist der Utopie de Ernst Bloch também poderia se chamar "Filosofia do Expressionismo", e que a crítica das formas enrijecidas (que provinha da Lebensphilosophie) como crítica da reificação e a estreita ligação entre arte e ética na crítica musical de juventude de Adorno mostram que a estética de Adorno tinha sua origem no movimento expressionista ("Dem Wahren Schönen Guten. Adornos Anfänge im Kontext", p. 316-7). Para além disso, ele analisa, em outro texto, os (maus) esforços literários de juventude de Horkheimer, enfatizando que: "Expressionismo significa também - e sobretudo - a busca pelo 'novo homem', o levante da geração dos 'filhos' contra os 'pais', cujo pensamento orientado por categorias econômicas se opõe ao ideal da 'personalidade' não atrofiada. Tudo isso encontra-se também em Horkheimer." Scheible ressalta aí as contradições políticas da sensibilidade guiada por uma Weltschmerz distanciada do mundo: "Justamente a radicalidade verbal do protesto expressionista permite supor que o ambicionado 'novo homem' por fim ficará preso às combatidas concepções burguesas". Um juízo crítico sobre o expressionismo certamente mais próximo de Lukacs do que Adorno ou Bloch. Scheible ainda afirma que somente a partir de sua ruptura com o expressionismo o pensamento de Horkheimer torna-se frutífero: "A autonomia do pensamento de Horkheimer começa somente quando ele abre mão das intenções expressionistas; ao mesmo tempo, as categorias schopenhauerianas perdem sua roupagem mítica e liberam seu teor social." Scheible, "Die Geburt der kritischen Theorie aus dem Geist des Expressionismus: Max Horkheimers frühe Aufzeichnungen", p. 155-7. Jorge de Almeida, por outro lado, vê como em Adorno, já nos seus escritos de juventude, se configurava antes uma dialética entre expressão e construção, tendo em vista sobretudo a música de Schoenberg, uma dialética que será retomada sobretudo na Filosofia da Nova Música (cf. Jorge de Almeida, Crítica dialética em Theodor Adorno). De fato, a relação de Adorno com o expressionismo não era sem conflitos: "Os que berravam a gritaria do Expressionismo, pretendendo na absolutização de seu Eu, que era uma fuga, criar a unidade dramática, hoje já perderam a voz de tanto gritar, e não podem mais ser levados seriamente em consideração." (Adorno, "Platz: Zu Fritz von Unruhs Spiel" GS 11, pp. 612-618 apud Almeida, cit., p. 47). Já para Bloch, ainda segundo Jorge de Almeida, "o cumprimento das exigências para a expressão pura do Eu deveria garantir, pela necessidade interna da forma, a superação da má individualidade
} 
Gottfried Benn, "a realidade era um conceito capitalista"155. Ainda em 1966, em sua Dialética Negativa, Adorno insistia em que: "A necessidade de dar voz ao sofrimento é condição de toda verdade." 156 Nessa imbricação entre sofrimento e verdade mantinha-se o vínculo entre a verdade e aquilo que ainda não era, uma vez que o sofrimento (que, para falar na língua da dialética, "porta uma negatividade") apontava para seu fim, para sua superação. A verdade era inquieta em relação à realidade à qual ela se referia. Ou, como colocou Ernst Bloch, tratava-se de um "realismo sem paz com o existente [Realistik ohne Frieden mit der Vorhandenheit]" ${ }^{\prime 157}$. O positivismo se apresentava como a ideologia mais eficiente na medida em que ali a força dos fatos, em sua positividade, ganhava legitimidade, e era justamente para além dos fatos, ou mais, contra "a má facticidade", que se deveria buscar a verdade: “A cientificidade, como tal, nunca é uma garantia de verdade e com maior razão não em uma situação em que a verdade mais fala contra os fatos e está por detrás dos fatos como hoje." ${ }^{158}$ A teimosia da teoria crítica em aferrar-se à verdade, assim defendia Marcuse, era uma qualidade em meio ao "oportunismo" na filosofia. A verdade ser incompatível com a realidade imediata não a desqualificava, pelo contrário, assegurava-lhe o elemento utópico: "Se a verdade não é realizável dentro da ordem social existente, mesmo assim ela tem para esta o caráter de mera utopia. Tal transcendência não fala contra, mas pela verdade." $" 159$

O autor que provavelmente levou mais adiante a ideia de que há uma relação entre verdade e utopia, e colocou claramente nestes termos, é Ernst Bloch, de modo que mesmo que tal ideia esteja presente em outros autores como Adorno, Marcuse e Horkheimer, não

em um Nós presente e pressuposto, que anteciparia na obra de arte a reconciliação futura a ser efetuada, na sociedade, pelos movimentos revolucionários." Ibid., p. 59.

${ }^{155}$ A esse respeito, Carlos Eduardo Jordão Machado afirma: "A realidade significava o liberalismo, o darwinismo, a guerra, a humilhação histórica, a injustiça e o poder, a dissolução da natureza e da história. A 'realidade', para Benn um conceito 'demoníaco', é a realidade da racionalização científica." Um capitulo da história da modernidade estética: debate sobre o expressionismo. São Paulo: Ed. Unesp, 2016, p. 15.

${ }_{156}^{156} \mathrm{DN}$, p. 24.

${ }^{157}$ Ernst Bloch, Philosophische Aufsätze zur objektiven Phantasie, p. 621

${ }^{158}$ Herbert Marcuse, "Filosofia e Teoria Crítica" in Cultura e Sociedade, p. 157.

${ }^{159}$ Ibid, p. 145 Há fundamentalmente uma contradição entre fatos (existentes) e liberdade (ainda não existente). No entanto, o que é verdadeiro é a liberdade. De tal modo que torna-se necessário um conceito de verdade que dê materialidade àquilo que ainda não existe, mas que não por isso carece de realidade: "Para a perserveração daqueles elementos teóricos, que se dirigem à liberdade futura, a teoria não pode invocar fato algum. Pois tudo o que já está alcançado lhe é dado como desaparecendo e ameaçado e isto é o fato positivo, um elemento da sociedade vindoura apenas na medida em que é tomado como algo em transfomação nessa construção.” Ibid, p. 147 
há como deixar de pensar os traços da obra de Bloch em toda essa geração de intelectuais. Michael Löwy conta de uma conversa com Bloch:

Parmi ses remarques, lors de notre entretien, il y a une qui m'a beaucoup frappé et qui résume la fidélité obstinée de toute une vie à l'idée de l'utopie: "Le monde tel qu'il existe $n$ 'est pas vrai. Il existe un deuxième concept de vérité, qui n'est pas positiviste, qui n'est pas fondé sur une constatation de la facticité [...] ; mais qui est plutôt chargé de valeur comme par exemple dans le concept "un vrai ami" [...] dans l'expression "un véritable ami" [il $\mathrm{y}$ a un] rapport à la sphère morale. Et si cela ne correspond pas aux faits - et pour nous marxistes, les faits ne sont que des moments réifiés d'un procès, et rien de plus - dans ce cas-là, tant pis pour les faits comme le disait le vieux Hegel." 160

A partir de tal concepção, a crítica da sociedade não se orientava a partir de um ideal regulador de justiça, visando eliminar as injustiças do mundo, mas operava com um conceito de verdade, segundo o qual "o mundo tal como ele existe é falso". Ou seja, o falso é ao mesmo tempo a injustiça e a não-liberdade. Não só do ponto de vista moral, mas também histórico: a verdade do mundo é mais do que o mundo tal como ele é enquanto atual, mas ainda naquilo que nele há de temporal, isto é, latência de futuro no presente atual - a verdade é, como aparece em um texto de 1936, um "retrato enérgico das tendências - latências [eingreifende Abbildung der Tendenzen - Latenzen]"161.

Contra os fatos, fazia-se necessária fantasia e imaginação tanto para compreender a realidade como para negá-la: na união desses dois momentos está a essência do conceito de verdade da teoria crítica. Passando do filósofo do "Princípio Esperança" Bloch para o do "Princípio Desespero" Günther Anders, nossa representação do mundo está, para o último, aquém da realidade da Era Nuclear (que, a rigor, não é uma era, pois sendo a derradeira, ela é um prazo), por isso somos incapazes de temer a bomba atômica, isto é, ao não conseguir imaginar a catástrofe, é possível normalizá-la, não temê-la. ${ }^{162} \mathrm{Um}$

\footnotetext{
${ }^{160}$ Michael Löwy, Ernst Bloch \& Theodor Adorno: lumières du romantisme. Disponível em: $\mathrm{http} / / / \mathrm{www}$.preavis.org/breche-numerique/spip.php?page=_imprimer\&id_article=1639\#nh4 (Acesso: 10/04/2017).

${ }^{161}$ Ernst Bloch, Tendenz-Latenz-Utopie, p. 250.

${ }^{162}$ A relação entre medo e esperança aqui não é ignorada, visto que desde Espinosa sabe-se que "não há esperança sem medo, nem medo sem esperança" (Espinosa, Ética, p. 221). Também Lacan disse em algum lugar, segundo Vladimir Safatle, que "viver sem esperança é também viver sem medo." Entende-se aqui (tanto para fins clínicos como para fins políticos) que tanto o medo quanto a esperança nos retiraria da "potência própria ao instante" assim como produziria "um corpo político providencial", o que, no limite, torna o sujeito preso a um horizonte, ou seja, melhor sem ele do que com - não há como deixar de ver aí uma resposta à leitura de Paulo Arantes em torno do rebaixamento das expectativas históricas (cf. Vladimir Safatle, $O$ circuito dos afetos, p.
} 
"déficit" imaginativo que impede tanto a compreensão do presente quanto uma ação (moral, política) que corresponda a ele. Como somos incapazes de imaginar a própria morte (e não só a morte individual, mas a morte do gênero humano), ela se torna aceitável. ${ }^{163}$ Se em Bloch a fantasia é necessária como consciência antecipatória do aindanão (a sociedade emancipada por vir), em Anders se necessita da fantasia para se perceber a catástrofe que já ocorreu. ${ }^{164}$ A barbárie consiste precisamente na nossa incapacidade de compreender a realidade devido à dimensão do horror que se apresenta objetivamente pela possibilidade real da aniquilação da humanidade, dada pela "mera" existência técnica

24-25). Salvo engano, Safatle pensa que tal "pessimismo" engendraria uma posição melancólica diante do destino que, por sua vez, leva à inação. Antes de tudo, seria preciso desmontar a ideia de que a esperança está sempre em uma posição providencial e, portanto, passiva - o próprio Ernst Bloch reiterou o quão equivocadas foram as leituras de seu Das Prinzip Hoffnung. Aliás, isso se expressa em parte já na diferença vocabular no alemão entre hoffen e warten (esse "warten" passivo e sem objeto é justamente o que guia a análise de Günther Anders de Esperando Godot). De todo modo, para Anders, esse Bloch às avessas (a utopia do ainda-não é substituída pela distopia da vida na Era Nuclear pós-Auschwitz como ainda-não-ter-sido-assassinado [Günther Anders, Die Antiquiertheit des Menschen I, p. 257]), faz o caminho reverso: carecemos de imaginação (moral e verídica) e coragem para o medo, enquanto a esperança aparece como covardia. A incapacidade para o medo e para a angústia é resultado da dessensibilização moral posta pela automação técnica do mundo que tende a transformar todos em potenciais Eichmanns. "Nada é mais falso que o chavão popular dos semi-formados de que vivemos na 'Era do Medo'. Tentam nos convencer disso os publicitários daqueles que têm medo de que nós criemos o verdadeiro medo, aquele medo adequado ao perigo. Vivemos muito mais na Era da Banalização [Verharmlosung] e da Incapacidade para o Medo. O mandamento de ampliar nossa imaginação significa então 'in concreto': nós devemos ampliar nosso medo. / Postulado: não tenha medo do medo, tenha coragem para o medo. E também a coragem de fazer medo. Amedronte teu vizinho como a ti mesmo. - Certamente esse medo deve ser de um tipo bem específico: 1. Um medo sem pavor [furchtlose Angst], pois ele descarta aquele medo diante daqueles que poderiam nos escarnecer como medrosos. 2. Um medo vivificante [belebende Angst], pois, ao invés de nos fazer refugiar na toca, ele deve nos lançar para as ruas. 3. Um medo amante [liebende Angst], que nos deve fazer temer pelo mundo, e não somente temer aquilo que pode nos acontecer." Günther Anders, "Thesen zum Atomzeitalter" in Die atomare Drohung. München: Beck, 2003, p. 98. Aliás, vale notar que o própria Marx visava botar medo para criar coragem, como ele diz na Introdução à Crítica da Filosofia do Direito de Hegel: "Man muß das Volk vor sich selbst erschrecken lehren, um ihm Courage zu machen." MEW 1, 381. De todo modo, podemos dizer que a ideia de que "a esperança venceu o medo" é uma derrota ideológica.

${ }^{163}$ Vide a epígrafe dessa seção, retirada de um romance de Céline, com um narrador-personagem em meio à Grande Guerra, que reproduzo aqui: "Quando não se tem imaginação, morrer não é nada; quando se tem, morrer é demais."

${ }^{164}$ Nos diários da viagem de Anders a Hiroshima e Nagasaki: "Há uma extrema falta de fantasia [Phantasielosigkeit] que se expressa como defeito da percepção. Aos passageiros, que, ao invés de olharem para o imenso e ártico Nada, estão convencidos de que lá não há nada (em minúsculo) para ver, a eles lhes faltam a capacidade de imaginar [vorzustellen] o perceptível. E esse defeito permanece até mesmo (pois de vez em quando eles são seduzidos pelo tédio a olhar para baixo) in actu da própria percepção. Eles são então por demais sem fantasia para verem o que eles vêem." Günther Anders, "Tagebuch aus Hiroshima und Nagasaki”. in Hiroshima ist überall. München: Beck, 1995, p. 13. 
da bomba atômica, que não pode ser desinventada. A ameaça é grande demais para que seja percebida. Isso é o que Anders chamou de "superliminar":

Com essa expressão, designamos, em oposição aos conhecidos estímulos subliminares (que são muito pequenos para ultrapassar o limiar do imaginável ou perceptível), aqueles estímulos que são grandes demais para que eles possam ser percebidos ou imaginados [vorgestellt]. Não é apesar de eles serem grandes demais que a ameaça permanece invisível, mas ao contrário, porque eles são grandes, a saber grandes demais. ${ }^{165}$

Se utopia, em sentido trivial, era uma fantasia sem pé na realidade, o presente potencialmente distópico é uma realidade sem pé na fantasia. Tornamo-nos, assim, utopistas invertidos: "Este o dilema fundamental de nossa era: nós somos menores que nós mesmos, a saber, somos incapazes de fazer uma imagem daquilo que foi feito por nós. Nesse ponto somos utopistas invertidos: enquanto utopistas são aqueles que imaginam o que não podem produzir, nós não conseguimos imaginar aquilo que produzimos." "166 A fim de conceber esse horizonte, também para Anders a "fantasia é realista" e a "sensualidade deturpa sentido"167: "Porque sensualidade [Sinnlichkeit] é fundamentalmente míope e limitada e seu horizonte absurdamente curto ['sinnlos' eng]. Não é a terra da fantasia o destino da emigração dos escapistas de hoje, mas a terra da percepção.” Por isso também o irrealismo do realismo: "Daí nosso mal-estar (justificado) e nossa desconfiança frente aos quadro pintados normalmente (a saber, na 'perspectiva normal com ponto de fuga' [normaler Fluchtpunktperspektive]): apesar de realistas em sentido convencional, justamente elas são irrealistas, já que contradizem "a realidade de nosso mundo, cujo horizonte perdeu-se de vista [Realität unserer weithorizontig gewordenen Welt]." ${ }^{168}$ Também em Adorno o caráter ideológico da indústria cultural consiste em seu pseudo-realismo, na duplicação daquilo que é: "na compacta armação da duplicação da realidade pela aparelhagem técnica do filme toda intenção, até mesmo a verdade converte-se em mentira."169 Há aqui uma convergência entre o "método" de

\footnotetext{
${ }^{165}$ Günther Anders, "Die Wurzeln der Apokalypse-Blindheit" in Die atomare Drohung. cit., p. 110.

${ }^{166}$ Günther Anders, "Thesen zum Atomzeitalter", cit., p. 96. Na experiência francesa da resistência durante a Segunda Guerra Mundial, o poeta René Char já dizia coisa parecida: " O homem é capaz de fazer o que é incapaz de imaginar. Sua cabeça rasga a galáxia do absurdo." "Feuillets d'Hypnos (1943-1944)" in Fureur et Mystère. Paris: Gallimard, 1967. (Tradução de Fernando Vidal).

${ }^{167}$ Günther Anders, "Thesen zum Atomzeitalter", cit., p. 97.

${ }^{168}$ Ibid.

${ }^{169}$ MM, p. 128
} 
compreensão da distopia em Anders e o da utopia nos frankfurtianos "clássicos". Se o lastro da imaginação era a utopia chamada "horizonte de expectativa" (nos termos de Reinhart Koselleck), o efeito subjetivo do encolhimento objetivo desse horizonte é o definhamento da imaginação, tema presente desde a Dialética do Esclarecimento, quando se anunciava precisamente que "a fantasia atrofia-se." 170 É em nome da possibilidade de futuro que Marcuse, em Filosofia e teoria crítica, coloca a relação entre verdade e fantasia nos seguintes termos:

Para preservar no presente o que ainda não está presente como meta, a fantasia é necessária. [...] Devido à capacidade única da imaginação de "intuir" um objeto mesmo ausente [ohne dessen Vorhandensein], de criar algo a partir do fundamento do material dado do conhecimento, a imaginação indica um elevado grau de independência, a liberdade em meio a um mundo de nãoliberdade. [...] Sem fantasia, todo conhecimento filosófico permanece sempre no presente ou preso ao passado, separado do futuro, o único que vincula a filosofia à história efetiva da humanidade. ${ }^{171}$

Também Horkheimer ligava a verdade ao momento subjetivo da "fantasia criadora": "Não há verdade sem atividade humana, sem a fantasia criadora [...] sem entusiasmo não há verdade.""172 Adorno, na Minima Moralia, fala da "fantasia interpretadora [interpretierende Phantasie]"173. Entretanto, é importante ressaltar: a fantasia não significa "escapismo", por isso ela é "objetiva" ou "exata"174. Ser contra a realidade ainda exige um realismo ou, justamente por isso: a exigência ética de que a realidade deve ser transformada carece de um conceito de verdade e todo relativismo

\footnotetext{
${ }^{170}$ Adorno; Horkheimer, Dialética do Esclarecimento.

${ }^{171}$ H. Marcuse, "Filosofia e teoria crítica", p. 155-156. A fantasia para Marcuse, como conceito extraído da psicanálise, mantém também o horizonte da satisfação pulsional e entra em contradição com o princípio de realidade (que torna-se ideológico em seu apelo àquilo que é): "Only one mode of thought-activity is 'split-off' from the new organization of the mental apparatus and remains free from the rule of the reality principle: phantasy is 'protected from cultural alterations' and stays commited to the pleasure principle. Otherwise, the mental apparatus is effectively subordinated to the reality principle." Marcuse, Eros and Civilization: a Philosophical Inquiry into Freud, p. 14. A verdade da fantasia está em sua negatividade, em sua relação à Grande Recusa: "Phantasy is cognitive in so far as it preserves the truth of the Great Refusal, or, positively, in so far as it protects, against all reason, the aspiration for the integral fulfillment of man and nature which are repressed by reason. In the realm of phantasy, the unreasonable images of freedom become rational, and the 'lower depth' of instinctual gratification assumes a new dignity." Idem, p. 160.

${ }_{172}$ HGS 6, p. 230.

${ }^{173}$ GS 4, p. 85.

${ }^{174}$ O termo "fantasia objetiva" ou "fantasia exata" é empregado por diversos autores, de Bloch a Adorno, passando por Horkheimer e Benjamin.
} 
trairia essa demanda. No debate contemporâneo, não é rara a desqualificação de toda pretensão à verdade como algo metafísico ou até mesmo autoritário, frente ao qual um certo relativismo epistêmico, variando a "humildade" positivista popperiana da falibilidade, aparece como mais “democrático” e mais fiel aos ideais liberais. ${ }^{175}$ Também alguém como Albrecht Wellmer acusa Adorno de permanecer preso ao ideal metafísico por tentar salvar um conceito de verdade que não seja a mera adequação entre um enunciado e um objeto, isto é, correção de uma proposição:

A questão de fato interessante: é por que Adorno viu-se obrigado a tentar o impossível - juntar, à força, um motivo marxista e um teológico a fim de salvar a verdade? Creio que a resposta a essa pergunta é que Adorno, em sua crítica do "pensamento identificador", tornou-se tão fortemente dependente das premissas da crítica nietzscheana do conceito, que ele só podia defender-se de suas consequências por meio de um golpe violento. A solidariedade de Adorno com a metafísica no momento de sua queda significa fundamentalmente fidelidade à ideia de verdade. ${ }^{176}$

Talvez de fato não se possa dizer que tal concepção de verdade seja absolutamente isenta de qualquer resquício metafísico, até por ela referir-se a um incondicionado - ao relacionar-se com aquilo que transcende a (má) realidade, a metafísica assume um teor utópico diante de um "realismo excessivo", de modo que tal "solidariedade com a metafísica no instante de sua queda" pode ser pensada como solidariedade com aquilo que (ainda) não existe no momento em que todo o potencial de transcendência (a “instância intramundana de transcendência" [Honneth]) parece desaparecer ${ }^{177}$. Nesse sentido, antes de identificar um certo conservadorismo filosófico na Dialética Negativa, é necessário entender que essa "fidelidade à ideia de verdade" (que é como Wellmer interpreta, corretamente, essa "solidariedade com metafísica") significa fidelidade ao

\footnotetext{
${ }^{175}$ Em termos hegelianos, tal modéstia teórica seria justamente a "falsa humildade" do "ficar na finitude". Cf. G. Lebrun, La patience du Concept: Essai sur le Discours hégélien, p. 182.

${ }^{176}$ Albrecht Wellmer, Metaphysik im Augenblick ihres Sturzes. in: Endspiele: Die unversöhnliche Moderne. Essays und Vorträge. Frankfurt am Main: Suhrkamp, 1999, p. 214.

${ }^{177} \mathrm{Um}$ interessante debate sobre a relação entre materialismo e metafísica se encontra na troca de cartas entre Adorno e Schole. Este, ao ler a Dialética Negativa, escreve para Adorno: "Se você me permite resumir minha opinião em uma única frase, então eu diria que eu nunca li uma defesa mais pudica e contida da metafísica.’Theodor W. Adorno, Gerschom Scholem. Briefwechsel 1939-1969. Hrg: Asaf Angermann. Berlin: Suhrkamp, 2015, p. 407. Ao que Adorno responde: "A intenção de salvar a metafísica é de fato central na Dialética Negatica. Fico bastante contente que isso apareça, e que você simpatize com isso." Ibid, p. 413.
} 
pressuposto filosófico original da teoria crítica, como estamos vendo aqui, em sua aspiração utópica pelo que não existe.

De todo modo, podemos reconhecer um traço metafísico em tal conceito de verdade, que evoca certa união do "Belo, Bom, Verdadeiro" dos antigos ${ }^{178}$, em uma coincidência entre a moral, a estética e a ciência - algo que no processo moderno de racionalização sofre uma cisão própria à autonomização das esferas, dando origem a uma independência entre esses tipos de juízo. Por essa via, tal conceito enfático de verdade dos frankfurtianos é, ao mesmo tempo, uma crítica da separação. Ou ainda, há algo de anacrônico nele, pois ele visa a unidade da razão justamente no momento de sua desintegração. Como diz Horkheimer: "Que aquelas ideias do verdadeiro, do belo, e do bom, não sejam separadas, mas que sejam um, como o fiel uma vez esperou, é também hoje o anseio [Sehnsucht] no mundo dilacerado."179 O que está pressuposto nessa separação é a fratura da modernidade e a divisão social do trabalho. Tal verdade exagerada e enfática é um conceito que extrapola os limites de "validade" (para falarmos como Habermas) e desrespeita a divisão social do trabalho (que dará origem às ciências particulares). ${ }^{180}$ Visando o caráter restrito do conceito de verdade que se desenvolvia no interior dessa divisão, Adorno criticava o empobrecimento do conhecimento:

Sem reflexão, a divisão social do trabalho é respeitada juntamente com a falta que se tornou patente no decorrer dos últimos duzentos anos: o fato de as ciências organizadas segundo a divisão do trabalho monopolizarem em si, de maneira ilegítima,

178 "O belo deixou de ser 'símbolo da eticidade' (Kant); no esteticismo ele foi reduzido ao estímulo sensorial, ao efeito que ele produz, e não mais reivindica verdade, mas esgota-se na mera 'harmonia' [Stimmung], que pode mudar de momento em momento. Após os diversos esforços de julgar o que lhe é concedido, parece ainda pior está para o bem [das Gute]." Hartmut Scheible, "Dem Wahren Schönen Guten. Adornos Anfänge im Kontext”, p. 272.

${ }^{179}$ HGS 14, p. 162. Especificamente em Horkheimer, o fator da crença na verdade é inflacionado e levado ao extremo a ponto de afirmar que há um "parentesco entre a verdade e o conceito de Deus" e que "só pode ocupar-se com a verdade aquele que a pressupõe". A própria crença na liberdade é compreendida como um passo histórico derivado da crença em Deus, ou seja, a liberdade não seria outra coisa senão Deus secularizado. HGS 14, p. 277-8.

${ }^{180} \mathrm{~A}$ ideia de desrespeito à divisão social do trabalho é inerente à própria figura do intelectual. Paulo Arantes, ao notar o paralelo entre a gênese do intelectual e o ressurgimento moderno da dialética na experiência do atraso na periferia europeia, observa que há um "desregramento ingênito do intelectual": "o intelectual é alguém que se mete no que não the diz respeito." $P$. Arantes, Ressentimento da Dialética, p. 78. Por isso, o intelectual desempenha um papel mais central em países periféricos, já que no centro do capitalismo (no caso, na Inglaterra) ele ocupa uma posição secundária em relação à hegemonia do expert, que de fato "sabe do que fala" e fala somente sobre o assunto que lhe cabe. Nele, não há nada de impostura. Adorno estava consciente disso: o sentimento de "charlatanice" imposto pelo positivismo acadêmico generalizado é tematizado em diversos aforismos da Minima Moralia. Hoje em dia, isso já tem seu lugar no rol das patologias psíquicas, e atinge sobretudo pós-graduandos e acadêmicos no mundo inteiro, ganhando o nome de "síndrome do impostor". 
a verdade. [...] A autoridade do conceito kantiano de verdade tornou-se terrorista com a proibição de pensar o absoluto. Irresistivelmente, isso impele para a proibição pura e simples do pensamento. O bloco kantiano projeta sobre a verdade a automutilação da razão que essa se infligiu enquanto rito de iniciação à sua cientificidade. É por isso que o que passa por conhecimento em Kant é tão pobre em comparação com a experiência dos viventes para a qual os sistemas idealistas, ainda que equivocadamente, queriam fazer justiça. ${ }^{181}$

Não custa lembrar que tal desrespeito da divisão social do trabalho imposto pelas ciências não é algo cometido somente pelos filósofos da Grécia antiga, mas está na base da própria ideia de Teoria Crítica com seu "materialismo interdisciplinar". E tal “interdisciplinariedade" não deve ser entendida somente como entrecruzamento das disciplinas particulares, mas ele é motivado pelo esforço de síntese inerente ao pensamento filosófico, que é por sua vez avesso à separação e à dissolução da ideia de verdade no ideal positivista de ciência. Mesmo Adorno, que em sua Dialética Negativa dedica longas páginas ao conceito tradicional de síntese, não abre mão de tal intenção ao falar, por exemplo, de uma "síntese não violenta", isto é, de uma síntese que não violente o objeto por meio do pensamento identificador que reduz o objeto ao sujeito, identificao às suas próprias ferramentas. Afinal, como diz o próprio Adorno, a crítica da lógica identitária não abandona sem mais a identidade: "o conhecimento do não-idêntico [...] identifica, mais e de maneira diversa da meneira do pensamento da identidade. Ele quer dizer o que algo é, enquanto o pensamento da identidade diz sob o que algo cai, do que ele é um representante, ou seja, aquilo que ele mesmo não é." ${ }^{\prime 182}$ Tal crítica do pensamento identificador, que mente por meio do conceito, já era feita por Nietzsche, que dizia que "todo conceito nasce por igualação do não-igual" ${ }^{183}$. Porém, isso não significa abrir mão da síntese e da identidade no pensamento: “A identidade não desaparece por meio de sua crítica; ela se transforma qualitativamente." ${ }^{184}$ A identidade permanece (a contragosto de Nietzsche) pois não se abre mão de conhecer as coisas como elas são - que é, ao mesmo tempo, um conhecimento de que as coisas devem mudar.

\footnotetext{
${ }^{181}$ DN, p. 322

${ }^{182}$ DN, p. 130

${ }^{183}$ Sobre verdade e mentira, in: Nietzsche, Obras Incompletas, p. 48

${ }^{184}$ DN, p. 130.
} 


\section{Verdade como arma}

É curioso ainda que um autor como Robert Kurz, não tão diretamente afeito a problemas filosóficos como eram Adorno ou Bloch, e sim mais preocupado em fornecer uma teoria da crise do capitalismo em seu estágio terminal, tenha deixado em seu espólio um ensaio inacabado intitulado A luta pela verdade, no qual insistia em que "o problema geral da verdade é assim também um problema especificamente 'de esquerda' ou 'marxista'." 185 Desde Marx, a verdade já possui uma dimensão prática, que extrapola o âmbito estrito do conhecimento, como ele diz em sua segunda tese sobre Feuerbach: "A questão se cabe ao pensamento humano uma verdade objetiva não é teórica, mas prática." ${ }^{\prime 186}$ A radicalidade da verdade (própria do "pensar-até-o-fim" dialético) tem o poder de desmontar os parâmetros pré-estabelecidos da consciência tanto teórica quanto prática, e nisso está sua “força material”, lembrando a célebre passagem do jovem Marx:

As armas da crítica não podem, de fato, substituir a crítica das armas: a força material tem de ser deposta por força material, mas a teoria também se converte em força material uma vez que se apossa dos homens. A teoria é capaz de prender os homens desde que demonstre sua verdade face ao homem, desde que se torne radical. Ser radical é atacar o problema em sua raiz. ${ }^{187}$

\footnotetext{
${ }^{185}$ Robert Kurz, A luta pela verdade. Tradução disponível em: http://www.obecoonline.org/rkurz411.htm

${ }^{186}$ Karl Marx, Teses contra Feuerbach. in: In: Manuscritos econômico-filosóficos e outros textos escolhidos. São Paulo: Abril Cultural, 1985, p. 51.

${ }^{187}$ MEW 1. Nessa citação de Marx, a ciência é colocada nem como completamente separada e nem como idêntica à política. Os textos Epilegômenos dialéticos sobre teoria e práxis e o Sobre sujeito e objeto de Adorno dizem coisas semelhantes. Quando Adorno parece defender a atividade teórica enquanto resistência, ele se refere justamente a essa "força material" da verdade de Marx, mas, assim como Marx, Adorno tem consciência que tal atividade intelectual é claramente limitada e que pensar que ela substituiria a política prática é uma ilusão. O mesmo vale para a arte: Adorno reconhece que, mesmo na arte mais radical, há algo de resignativo. Daí o caráter horripilantemente ideológico daquilo que muitos adornianos defendem: de que "haveria uma saída", mesmo que modesta, na arte e na filosofia. Tal pensamento é tanto mentira quanto um consolo banal frente à seriedade da afirmação de que não há saída, basicamente uma recusa a encarar o verdadeiro problema, e é a aceitação de um horizonte histórico rebaixado. Para Adorno, a práxis política não se torna prescindível e nem é substituída pela arte e pela filosofia. Em seu curso sobre estética de 1958/9, ele diz: "Quando pessoas como eu, por assim dizer, assumem na arte posições vanguardistas e bastante extremas, então deve-se ter clareza de que neste radicalismo esconde-se algo bastante não radical, e poderíamos quase dizer, algo de resignado, e que há situações, nas quais a arte radical pode tornar-se um álibi para a renúncia à práxis transformadora." Adorno, Ästhetik (1958/59). Suhrkamp: Frankfurt am Main, 2009, p. 195. Vale também inserir a informação extra-textual de que este trecho fora grifado por Adorno na transcrição dos cursos. Mais tarde, na Teoria Estética, Adorno escreve: "Há mesmo na arte radical tanta mentira, pois ela falha em produzir o possível, que ela produz enquanto aparência. As obras
} 
Mantendo a força do "espanto" dos antigos, sobretudo em Hegel a verdade tem força desestabilizadora: "o verdadeiro é delírio báquico no qual nenhum membro escapa à embriaguez." "188 Bloch diz: "a verdade liberta"189. Lenin: "A doutrina de Marx é onipotente, porque ela é verdadeira."190 Também para Lukacs, a verdade, quando "audaciosa", será decisiva: "Para o proletariado, a verdade é uma arma portadora da vitória e o é tanto mais quanto mais audaciosa for. [...] Para o proletariado, e somente para o proletariado, uma noção correta da essência da sociedade é um fator de poder de primeiríssima ordem, talvez até a arma decisiva." ${ }^{191}$ Mesmo que o proletariado deixe de ser o portador da verdade e destinatário da teoria, o caráter prático da crítica e da verdade permanece ("a verdade é um momento da práxis correta"192), embora a forma desse

de arte retiram seu crédito de uma práxis que ainda não começou e que ninguem saberia dizer se seus honorários serão recompensados.” Adorno, Ästhetische Theorie, p. 129.

${ }^{188}$ Hegel, Fenomenologia do Espírito, p. 53

189 O original, "Wahrheit macht frei", traz pela rima uma lembrança macabra. Ernst Bloch, Philosophische Aufsätze zur objektiven Phantasie, cit., 596.

${ }^{190}$ Lenin, Drei Quellen und drei Bestandteile des Marxismus, apud Bloch, O Principio Esperança, p. 273. Doravante, PE.

${ }^{191}$ Georg Lukacs, História e consciência de classe, p. 171. Em Lukacs, essencial é o ponto de vista que permite a visão da totalidade e o acesso à verdade (claro está que é o ponto de vista do proletariado). Esse ponto de vista verdadeiro era dado sobretudo porque a ação do proletariado era verdadeira. Posteriormente, o vínculo entre ação e verdade passa a ser lido como dogma para a justificação do existente, tal como se expressa no teor da crítica de Merleau-Ponty ao ultrabolchevismo de Sartre: "A certeza de ser portador da verdade é vertiginosa. É por si mesma violência. Como poderei saber o que Deus quer, dizia Coûfontaine, se não experimentar. Se tiver sucesso é porque Deus estava comigo. Também o bolchevique no poder [...] tem certeza de agir segundo a verdade desde que o que ele faça dê certo: portanto, estava permitido, pelas coisas e pela verdade inelutável do socialismo. Aqui, a relação se inverte: no ponto de partida, a ação do Partido e dos líderes dava certo porque era verdadeira. Mas o verdadeiro do momento só é acessível através da ação: portanto, é preciso experimentar, e o que der certo era verdade." Maurice Merleau-Ponty, As Aventuras da Dialética, p. 166-7. Claro que esse vínculo entre o que "dá certo" e a verdade é apologético na medida em que justifica o curso do mundo - o interesse frankfurtiano é, ao contrário, na verdade contra o curso do mundo. Como diz Bloch: "em Marx, um pensamento não é verdadeiro por ser proveitoso, mas proveitoso por ser verdadeiro." $\mathrm{PE}, \mathrm{p}$. 273. De outra forma, a crítica a essa vinculação entre política e verdade como autoritarismo de esquerda encontra-se igualmente em Foucault, que diz: "Não utilizem o pensamento para dar a uma prática política um valor de Verdade [...]." Foucault, "Introdução a uma vida não fascista" (no caso de Foucault, como o vínculo entre política e história havia sido rompido, a "verdade" também já não passada de um discurso de poder). De todo modo, Adorno certamente também não era simpático ao Partido como locus da verdade: "A frase de Brecht de que o Partido possui mil olhos, enquanto o indivíduo só possui dois, é falsa como toda sabedoria de botequim. A imaginação exata de um dissidente pode ver mais do que mil olhos nos quais se colocaram os óculos rosa da unidade, de modo que aquilo que eles olham é confundido com a universalidade do verdadeiro e regredido." $N D$, p. 47. Tal anti-dogmatismo não leva necessariamente a uma ideia de verdade universal que independe do sujeito que a porta, pois, como diz Horkheimer, "uma frase verdadeira torna-se, nas mãos erradas, não-verdadeira." HGS 14, p. 232.

${ }^{192}$ Horkheimer, "Zum Problem der Wahrheit”, p. 256. 
vínculo perca seu lastro original. Assim como o jovem Marx e Lukacs haviam defendido a crítica enquanto arma, também para Horkheimer "a teoria é agressão":

Teoria arremessa estilhaços assim como a agressão não sublimada. Teoria não é uma coleção de explicações, mas algo que deve transformar o mundo e nasce desse desejo. [...] É mais adequado caracterizar uma teoria como morta ou viva [do que como correta ou falsa]. ${ }^{193}$

O problema da verdade raramente é enunciado por Adorno de forma direta, menos ainda ele o define. Porém, a palavra "verdade" no texto de Adorno (e em grande parte da tradição dialética) tem um peso evidente, pronunciada de modo anti-banal, em um tom que lembra os iluministas franceses do século XVIII, para os quais a crítica e a verdade tinham uma dimensão política imediata e se vinculavam ao porvir, como aparece nas palavras de Voltaire: "A crítica tem razão; eu a amo e a honro. A plateia esclarecida julga os combatentes, e a razão sadia triunfa com o tempo." 194 Tal como na disputa entre os combatentes de Voltaire (o modelo é a "guerra de todos contra todos"195 da république des lettres), também Marx evocava a crítica que ocorria na luta, a "Kritik im Handgemenge" ${ }^{\text {,196 }}$, de modo que a crítica, o conhecimento e a luta pela emancipação aparecem embaralhadas no mesmo processo.

Com isso, a verdade traz toda a dimensão do anseio (que em alemão significa ao mesmo tempo nostalgia [Sehnsucht]). Na Teoria Estética e nos ensaios de crítica musical e literária, ao referir-se à verdade estética ou ao teor de verdade de uma obra, Adorno pouco visa o caráter descritivo ou "realista" (em sentido tradicional) da obra, mas antes uma relação antitética com a empiria. Tal antítese com o presente estático ocorre sobretudo por meio de um conceito processual e temporal de verdade ${ }^{197}$, que nega todo absoluto perene e todo presente. Daí sua preferência pelas artes do tempo (música) em

\footnotetext{
${ }^{193}$ HGS 14 p. 224.

194 apud Reinhart Koselleck, Crítica e Crise, p. 102.

195 "Só imerso na liberdade absoluta é possível desencadear o processo crítico que encontra a verdade. Na república das letras, portanto, cada um é soberano em relação a todos e, ao mesmo tempo, sujeito ao juízo de todos. A guerra civil, que havia sido eliminada pelo Estado, reaparece de forma inesperada, precisamente no foro interior privado que o Estado teve que conceder ao homem enquanto tal. Nele reina a liberdade absoluta, o bellum omnium contra omnes. A meta comum de todos é a verdade, e o verdadeiro soberano do compate espiritual é a crítica, que todos exercem e à qual todos se sujeitam." Koselleck, Crítica e Crise, p. 97-98.

196 "A crítica que se ocupa com esse conteúdo é a crítica na briga [Handgemenge], e na briga não importa se o adversário é um adversário nobre, de mesmo nível, interessante, importa acertá-lo." MEW 1, p. 381.

${ }^{197}$ Sobre isso, Adorno deixa mais clara sua posição em seu curso Einführung in die Dialektik. Voltaremos a isso mais adiante.
} 
relação às artes do espaço (pintura). A crítica adorniana a Stravinski se funda em larga medida na crítica da espacialização do tempo musical, na qual o elemento processual é anulado: "Toda pintura, também a abstrata, tem seu pathos naquilo que é; toda música visa um tornar-se, e disso ela pretende-se despojar em Stravinski por meio da ficção de sua mera existência."198

Se em Adorno tal temática está frequentemente escondida, em Horkheimer a preocupação torna-se mais evidente, e merece nota: se buscarmos o termo "verdade" no índice das obras completas de Horkheimer, entre ensaios e fragmentos, aparecem nada menos que 46 ocorrências, somente nos títulos (Adorno, por outro lado, emprega com certa frequência a palavra "verdade", mas jamais a colocou em um título). Além do mais conhecido Sobre o problema da verdade de 1935, existem diversos fragmentos (vários deles fazem parte das Notizen que foram publicadas postumamente por Alfred Schmidt) com títulos como Verdade e justiça, Verdade no discurso, Verdade e tempo, Vontade de verdade, Verdade condicionada, Liberdade e verdade, Verdade e dialética, Linguagem e verdade, entre vários outros. ${ }^{199}$ Tais textos tampouco se restringem ao período da produção do "velho" Horkheimer "metafísico", como costumam dividir sua obra, mas estão espalhados ao longo de toda sua obra. Tal como na crítica da economia política, o

${ }^{198}$ GS 12, p. 174-175. Eraldo Souza dos Santos, em seu artigo Variationen über das bilderlose Wesen der Musik: Bilderverbot als Motiv der Musikphilosophie Theodor W. Adornos [no prelo], explora a relação entre o caráter temporal da música e a Bilderverbot [proibição de imagens], o que nos interessa aqui precisamente porque no conceito de verdade em Adorno há também uma proibição de imagens, daí seu caráter negativo. Também na "dinâmica da música verdadeira", assim explica o autor, "nenhuma imagem pode ser figurada: nem uma imagem daquilo que meramente é, nem a imagem de um estado liberado."

${ }^{199}$ Os títulos em que aparecem o termo "verdade" nos textos de Horkheimer disponíveis nos 19 volumes em seus escritos reunidos (Gesammelte Schriften) dão já uma ideia das relações nas quais a verdade aparece: Uninteressiertes Streben nach Wahrheit ; Zum Problem der Wahrheit [1935] ; Judentum, Wahrheit, Wahn ; Wahrheit und Gerechtigkeit ; Die Wahrheit des Positivismus ; Die Wahrheit der Religion ; Wahrheit in der Rede ; Der Fluch ist die Wahrheit ; Wahrheit und Zeit ; Kein Weg zur Wahrheit ; Vom Ursprung der Wahrheit ; Wahrheit im Denken [Aus einer theologischen Diskussion] ; Wissenschaft, Wahrheit und Bildung [Gespräch mit Otmar Hersche] ; Über die Grenzen wissenschaftlicher Wahrheit, Gespräch mit Dagobert Lindlau ; [Wille zur Wahrheit]; Stern der Wahrheit ; Die Wahrheit im Christentum ; Ungeschichtlichkeit der Wahrheit [I,II] ; Liebe zur Wahrheit-willkürlich ; Bedingte Wahrheit ; Sprache und Wahrheit ; Wahrheit-Freiheit-Mensch; Die Wahrheit ist das Ganze; Das mystische Element der Wahrheit (Hegel) ; Erkenntnis und Wahrheit ; Über die Wahrheit [I,II,III] ; Freiheit und Wahrheit ; Die Werte und die Wahrheit ; Wahrheit und Zivilisation; Wahrheit [I, II] ; Wahrheit und Richtigkeit ; Wo die Philosophie beginnt, oder das Kriterium des Anspruches auf Wahrheit versus bloßes Bla-Bla und Verzicht auf das Denken; Die Wahrheit des Nationalismus [I, II] ; Die Wahrheit des Helvetius ; Die Wahrheit und das Gute sind ephemer ; Was heißt Wahrheit? ; Goethe über Wahrheit und Irrtum ; Wahrheit im Denken ; Wissenschaft und Wahrheit ; Wahrheit und Dialektik. 
conhecimento e a recusa do existente não são momentos separados e nem separáveis, há uma imbricação entre o lógico-descritivo e o ético-prático. ${ }^{200}$ No texto fundante Teoria Tradicional e Teoria Crítica, Horkheimer escreve que "aceitar isso [as categorias econômicas e a ordem social] simplesmente aparece como uma inverdade torpe: o reconhecimento crítico das categorias dominantes na vida social contém ao mesmo tempo a sua condenação.",201

\section{Bilderverbot: verdade negativa.}

Nós podemos somente dizer que o mundo não deve ser como ele é e esperar [hoffen] que essa frase tenha um sentido. Como ele deve ser, nós não podemos dizer.

Horkheimer, Notizen ${ }^{202}$

Eles [Marx e Engels] eram inimigos da utopia em nome de sua realização.

\footnotetext{
${ }^{200}$ Citando mais uma vez Merleau-Ponty: "Não há nada mais marxista que a mistura entre fato e significação, com a ressalva de que o marxismo não os mistura no equívoco, mas numa gênese da verdade, não esmaga dois opostos um no outro, mas faz deles duas balizas do mesmo caminho." As aventuras da dialética, p. 147.

${ }^{201}$ Max Horkheimer, Teoria tradicional e teoria crítica, p. 139. A dimensão prática da verdade pode dar a entender que haveria uma identidade entre teoria e prática, o que é equivocado. Apesar da crítica da predominância da práxis sobre a teoria, uma teoria que não se relaciona com a práxis, para Adorno, é vazia: "Uma teoria que não contenha relação alguma a qualquer práxis possível (e isso vale também para a arte) torna-se ou um jogo vazio, vaidoso e indiferente, ou, ainda pior, ela torna-se um elemento da mera cultura, ou seja, um conteúdo acadêmico morto, que é totalmente indiferente para nós enquanto espíritos vivos e pessoas ativas [lebendige Geister und lebendig handelnde Menschen]. Por mais mediada, indireta e escondida que seja esta relação, ela tem que estar lá. Inversamente (e isso eu já mencionei anteriormente), a práxis, que em nome de seu predomínio sobre a teoria faz-se simplesmente autônoma e enxota o pensamento para fora, degenera em movimento automático [Betriebsamkeit]. Uma tal práxis se enrijece no interior da existência dada [des Gegebenen]; ela leva a existência daquelas pessoas que gostam de organizar eventos, que acreditam que ao organizar qualquer coisa, qualquer manifestação prática, já algo essencial estaria sendo feito, sem que se pondere se tais práticas efetivamente interveem na realidade." Adorno, Probleme der Moralphilosophie, p. 17 (doravante, PdM). Também na Dialética Negativa, Adorno afirma: "A exigência da unidade entre praxis e teoria rebaixou iressistivelmente a teoria até torná-la uma serva; ela alijou da teoria aquilo que ela teria podido realizar nessa unidade. $\mathrm{O}$ visto prático que se reconquista de toda teoria foi subjugada no interior da célebre relação teoria-prática, ela se tornou aconceitual, uma parte da política para fora da qual ela gostaria de conduzir; ela é entregue ao poder. A liquidação da teoria por meio da dogmatização e da interdição ao pensamento contribui para a má prática; é de interesse da própria prática que a teoria reconquiste sua autonomia.” DN, p. 125. Essa noção dialética de que somente quando a teoria se distancia da imediaticidade da prática ela torna-se útil à prática é análoga à ideia de "as doutrinas sem compaixão são mais misericordiosas que as doutrinas dos lacaios morais da burguesia" (Dialética do Esclarecimento), essas sim imediatamente "calorosas" e compassivas. Retomaremos o problema da compaixão no capítulo 3.

${ }^{202}$ HGS 14, p. 305.
} 
Adorno, Dialética Negativa ${ }^{203}$

Ao abordarmos o conceito de verdade tal como ele é posto em operação pelos autores da teoria crítica, encontramo-nos na difícil situação de não encontrar nenhuma definição de verdade. Entretanto, sabe-se que desde Hegel o pensamento dialético não é afeito a definições, de modo que a compreensão do conceito não é dada de antemão, mas somente no processo do conhecimento. A definição seria impor rigidez e imobilidade àquilo que não é estático, àquilo que ainda não foi decidido, onde reside a possibilidade do desbloqueio do novo na história. Nos termos de Horkheimer: "O caráter decidido [Entschiedenheit] de nossa definição de verdade não nos salva do caráter indecidido [Unentschiedenheit] da história."204 A impossibilidade de apreender uma definição positiva de verdade nesses textos se deve ao fato de que o conceito de verdade em operação tanto em Adorno como em Horkheimer é negativo, ou antes, sem imagens. ${ }^{205} \mathrm{~A}$ rigor, não há uma "apreensão" da verdade em sentido positivo, mas há tão somente uma via negativa por meio do conhecimento do falso, de modo que a verdade está sempre radicalmente imbricada em seu contrário. ${ }^{206} \mathrm{~A}$ frase de Espinosa, de que a verdade é índice de si mesma e do falso, é invertida por Adorno: "variando uma célebre frase de Espinosa, o falso, uma vez determinadamente conhecido e precisado, já é um índice do

\footnotetext{
${ }^{203}$ DN, p. 268.

${ }^{204}$ HGS 13, p. 283.

${ }^{205}$ A princípio parece dar um curto-circuito a ideia de uma "imaginação sem imagens" (Gerard Lebrun empregou o termo em seu Kant e o Fim da Metafisica), mas creio que é por esse caminho que segue Adorno. Na Dialética Negativa torna-se explícita a crítica de Adorno às imagens, em que o materialismo funciona como uma secularização do motivo religioso da "proibição de imagens": "Uma consciência que inserisse entre ela e aquilo que ela pensa um terceiro elemento, as imagens, reproduziria sem perceber o idealismo; um corpo de representações substituiria o objeto do conhecimento, e o arbítrio de tais representações é o arbítrio daqueles que decretam. $\mathrm{O}$ anseio [Sehnsucht] materialista de conceber o objeto quer o contrário: só sem imagens seria possível pensar o objeto plenamente. Uma tal ausência de imagens converge com a interdição teológica às imagens. O materialismo a seculariza na medida em que não permite que se pinte a utopia positivamente; esse é o teor de sua negatividade. Ele está de acordo com a teologia lá onde é maximamente materialista." DN, 176.

${ }^{206}$ Em seu curso de introdução à dialética, Adorno inclusive fala da imbricação entre verdade e inverdade, isto é, do quão facilmente a verdade passa à inverdade (por exemplo, na tentativa de fixar a verdade), e vice-versa, a verdade necessariamente passa pela inverdade: "Aqui vocês podem perceber bastante claramente o que constitui em geral o nervo vital da dialética: que verdade e inverdade, a saber, não são externas uma a outra, que verdade e inverdade não se opõem [gegenüberstehen] uma a outra numa antítese abstrata, mas que a verdade mesma, como seu destino, como sua maldição, como o signo do nexo de culpa no qual ela está, é inerente [innewohnt] à passagem [Übergehen] na inverdade; e que, ao contrário, o caminho que a verdade percorre - e a verdade é um processo - somente existe por meio da inverdade." Adorno, Einführung in die Dialektik, p. 80. Dorvante, EiD.
} 
correto, do melhor." 207 O que passa a operar é uma Bilderverbot, uma "proibição de imagens": assim como na tradição religiosa Deus (ou seja, o infinito) é irrepresentável, a verdade (e a utopia) não se permite representar, pois a representação implica necessariamente um falseamento. Tal motivo fora elaborado já na tese de Adorno sobre Husserl:

A verdade então não pode mais ser pensada como concordância estática, nem como 'intenção'. Se o Husserl inicial, propriamente fenomenológico, polemizou de modo pertinente contra a teoria das imagens e dos sinais do conhecimento, então também essa polêmica poderia ser voltada contra a ideia sublimada de que o conhecimento seria imagem de seu objeto por força da semelhança, da adeaquatio. Somente com a ideia da verdade sem imagens é que a filosofia atingiria a proibição às imagens. ${ }^{208}$

Nas Notizen de Horkheimer, ele escreve: "O bem [das Gute] - não só a verdade, mas o bem por excelência - não se permite definir. Não somos capazes de representar Deus, mas sim o mau [das Schlechte]. Em certo sentido, isso vale também para a beleza. [...] Não a verdade totalmente, mas momentos da verdade podem ser inerentes ao pensamento." ${ }^{209}$ Essa proibição de imagens própria ao conceito de verdade tem, como seria de se esperar, consequências para a moral. Como diz Adorno em aula: "Nós não podemos saber o que é o bem [Gute] absoluto, a norma absoluta, ou sequer o que é o homem ou o humano e a humanidade, mas o que é a desumanidade, isso nós sabemos muito bem." 210 Não há outro caminho possível senão pelo negativo. Aplicando retroativamente um problema que se tornou decisivo na filosofia contemporânea (principalmente a partir de Habermas), se pensarmos em termos de normatividade, diríamos que há (e isso não vale somente para Adorno, mas talvez para toda a tradição dialética da teoria crítica) uma normatividade negativa em operação. A citação de Horkheimer é tão simples quanto sintética: conhecemos o mundo, e o nosso conhecimento diz que as coisas não devem ser como elas são. Na base da verdade está o não dever ser da realidade dada - mas um dever ser positivo é proibido à teoria. Há uma espécie de caráter finito da teoria, e portanto qualquer normatividade ou verdade positiva,

\footnotetext{
${ }^{207}$ Adorno, "Kritik" in GS 10.2, p 793.

${ }^{208}$ Adorno, Para a metacrítica da teoria do conhecimento, pp. 228-9.

${ }^{209}$ HGS 13, p. 102.

${ }^{210}$ PdM. Freyenhagen denominou isso de "negativismo epistêmico" - no entanto, ele se limita a defender um "aristotelismo negativo" de Adorno, sem sequer entrar na questão da dialética. Essa crítica a Freyenhagen está mais desenvolvida em: Felipe Catalani, Adorno: a negatividade e as normas, Revista Dissonância.
} 
isto é, qualquer tentativa de dizer como as coisas devem ser, assim como toda representação divina, implica um falseamento e sacrifica o porvir na nomeação do que não deve ter nome. Claro, tal afirmação se torna tanto mais verdadeira quando a Revolução não está na ordem do dia e toda resposta à questão “O que fazer?” se torna ideológica, pois a mentira da resposta trai a verdade da pergunta: "Se a interdição às imagens se estendia outrora até o uso do nome, essa interdição tornou-se agora, sob essa forma mesma, suspeita de superstição. A interdição intensificou-se: só pensar na esperança já é um pecado contra ela e trabalha contra ela."211

\section{De volta aos fatos: Habermas e a correção}

A ruptura de Habermas com a tradição dialética da teoria crítica, da qual ele é descendente direto, poderia ser traçada de várias formas. O mais importante, talvez, seja ele operar com um horizonte de expectativas rebaixado ${ }^{212}$, condizente com as transformações históricas que lhe são contemporâneas - nesse aspecto, ele é um pensador atento e perspicaz, mais frutífero que diversos pupilos frankfurtianos que se limitaram a glosar seus antigos professores. Essa mudança de registro temporal, na qual surge uma "nova intransparência" para a vista que busca o horizonte, Habermas já testemunhava em seu ensaio A crise do Estado de Bem-Estar Social e o esgotamento das energias utópicas. Calcado também na leitura de Koselleck acerca da temporalização moderna da história, ele escreve:

Desde o fim do século XVIII, a história é concebida como um processo mundial que gera problemas. Nele, o tempo é entendido como um recurso escasso para a superação prospectiva dos problemas que o passado nos legou. [...] a moderna consciência do tempo inaugura um horizonte onde o pensamento utópico funde-se ao pensamento histórico [...]. A perspectiva utópica inscreveu-se na própria consciência da história politicamente eficaz. Pelo menos assim pareceu até ontem. Hoje as energias utópicas aparentam ter se esgotado, como se elas tivessem se retirado do pensamento histórico. O horizonte do futuro estreitouse e o espírito da época, como a política, transformou-se profundamente. O futuro afigura-se negativamente; no limiar do

\footnotetext{
${ }^{211}$ DN, p. 332.

${ }^{212}$ Sobre a ideia de rebaixamento do horizonte de expectativa, cf. P. Arantes, "O novo tempo do mundo".
} 
século XXI desenha-se o panorama aterrador da ameaça mundial aos interesses da vida em geral $[\ldots] .{ }^{213}$

O que Habermas está enxergando, a partir de Claus Offe, é o próprio colapso da sociedade do trabalho (que ele não compreende como colapso), que começa a mostrar seus sinais nos anos 1970, e a potencialidade de emancipação na teoria habermasiana é deslocada do trabalho (ao qual estariam vinculadas as antigas "energias utópicas") para a linguagem ${ }^{214}$, de modo que há uma utopia, que, no entanto, está desvinculada de uma teoria da história: a emancipação não é algo a ser realizado no futuro (de acordo com a temporalização moderna da história), mas é algo semi-presente. Talvez aquilo que aparece como uma mudança de registro na obra habermasiana pode ser pensado como uma reação a essa "mudança de época", à crise dos anos 1970. Variando uma frase de Adorno, Habermas torna-se solidário com o welfare state (do qual dependem as democracias ocidentais do pós-guerra) no instante de sua queda.

Por outro lado, podemos dizer que o que há de ideológico em Habermas se encontra menos em sua utopia comunicativa (nada mais legítimo que o desejo de que as pessoas se entendam), como se costuma criticar em sua obra, mas antes em sua identificação da emancipação com o presente, que se tornará uma defesa obstinada daquilo que, a rigor, não passava de uma fachada de pacificação (o próprio mundo do pós-guerra, que abordamos no capítulo anterior). Filosoficamente, isso se expressa sobretudo na dissolução do conceito enfático de verdade que permeia a dialética de Hegel a Adorno, que é ao mesmo tempo a dissolução do elemento negativo da teoria da qual depende sua aspiração utópica por aquilo que não existe. Se Adorno afirmava que "a

\footnotetext{
${ }^{213}$ Habermas, "A crise do Estado de Bem-Estar Social e o esgotamento das energias utópicas"

${ }^{214}$ É no mínimo curioso a simultaneidade desse giro linguístico na filosofia acadêmica europeia, tanto na França como na Alemanha. O fim de linha histórico deu à linguagem um caráter definitivamente compensatório configurando, como diz Paulo Arantes, a ideologia da "lingustic turn internacional que descartava, por exemplo, as teorias 'representativas da verdade', ao mesmo tempo em que conferia poderes demiúrgicos à linguagem, 'arquiteto e árbitro final de toda sociabilidade'. Daí a gangorra escarnecida por Perry Anderson: o que do lado francês era 'equívoco, obscuro e maldito', aparecia 'translúcido e redimido' do lado alemão; enquanto em Paris a linguagem demonizada 'bombardeava o sentido, devastava a verdade, atacava pelos flancos a ética e a política, exterminava a história', na Alemanha encarregava-se o mesmo protagonista impalpável de 'restaurar a ordem histórica, prover o bálsamo do consenso para a sociedade, assegurar os fundamentos da moralidade, fortalecer os elementos da democracia', sendo enfim congenitamente avessa a se desviar da verdade, horizonte antecipado de cada ato de fala." Paulo Arantes, Tentativa de identificação da ideologia francesa: uma introdução, p. 74-98. Vale lembrar ainda que a outra aposta, essa especificamente francesa, após a crise do mundo do trabalho (pensando em certa definição corrente de "forma de vida" como trabalho, desejo e linguagem), foi a Filosofia do Desejo.
} 
crítica lógica e a enfático-prática, de que a sociedade precisa ser transformada, são momentos do mesmo movimento do conceito" 215 , isso é, que a rigor não havia separação entre conhecimento e moral, Habermas buscará, retornando a Kant, separar o momento normativo do descritivo. As três "debilidades da Teoria Crítica" que Habermas aponta nos antigos frankfurtianos são: o conceito de razão, o conceito enfático de verdade em sua relação com as ciências e o desprezo pela democracia burguesa ${ }^{216}$ (ou seja, nota-se como tais "debilidades" estão articuladas). Para Habermas, aparece como problemático o "conceito de verdade recolhido de Hegel, que os antigos frankfurtianos jamais abandonaram e que é incompatível com o falibilismo do trabalho científico." ${ }^{217}$ Habermas busca, assim, alterar os pressupostos filosóficos da teoria crítica ao voltar-se para um ideal de conhecimento científico que deve lidar somente com "pretensões de verdade proposicional":

[...] os frankfurtianos se aferraram a um conceito de teoria, a um conceito de verdade que se apoia no conceito enfático de razão da tradição filosófica. É o mesmo conceito que, na formulação "razão instrumental", retorna de modo irônico. Com efeito, a "razão" não deve recobrir justamente apenas as intenções de verdade, no sentido estrito em que falamos da verdade de enunciados. Pelo contrário, a razão deve mostrar em sua unidade os momentos racionais que foram decompostos em todas as três críticas kantianas: a unidade da razão teórica com o discernimento prático-moral e com a faculdade de julgar estética. / Quando se faz ciência, e quando se faz filosofia nesse quadro, é preciso lidar, no entanto, só com pretensões de verdade. Por conta disso surge um embaraço. De um lado, a conceitualização da teoria enfática deve estar talhada para 'verdades' das quais os momentos morais e estético-expressivos ainda não estão apartados; de outro lado, também uma teoria crítica da sociedade precisa proceder cientificamente; ela só pode fazer enunciados que se vinculam a uma pretensão de verdade proposicional. ${ }^{218}$

A verdade se limita então a correção de uma proposição, aproximando-se, ao menos nesse aspecto, da concepção positivista contra a qual a teoria crítica se voltava desde o momento de seu surgimento. As prescrições normativas e as asserções descritivas passam a operar em campos de validade distintos. E de fato, se procedermos como os

\footnotetext{
${ }^{215}$ Adorno, Introdução à controvérsia sobre o positivismo na sociologia alemã, p. 233.

${ }^{216}$ Habermas, A nova obscuridade, p. 247-8.

${ }^{217}$ Ibid.

${ }^{218}$ Habermas, A nova obscuridade, p. 250-1.
} 
analíticos, com frases isoladas, abstraindo a totalidade social, não há como não dar razão (bastaria comparar as proposições "matar é errado" e "a rosa é vermelha"). Vejamos como Habermas se posiciona:

[...] mal se pode falar de um "saber" moral, pois, prima facie, não se pode pensar aqui num saber factual. Não se permite uma assimilação indiferenciada de convicções morais a opiniões de conteúdo empírico, pois há uma diferença flagrante entre seus sentidos de validade. As asserções dizem o que é o caso, enquanto prescrições ou proibições dizem qual deve ou não ser o caso. Saber como as coisas se encadeiam "efetivamente" é diferente de exigir o que deve ser feito - ou saber como nossas ações "têm de" se engrenar para que seja possível uma convivência correta ou justa. O saber moral se distingue do empírico já por sua referência à ação. Ele diz como as pessoas devem se comportar, e não o que se passa com as coisas. A "verdade" de proposições descritivas significa que os estados de coisa enunciados "existem", enquanto a "correção" das proposições normativas refletem o caráter obrigatório dos modos de agir prescritos (ou proibidos). Kant pretende fazer justiça a essa diferença entre saber epistêmico e saber prático distinguindo, relativamente à faculdade de conhecer e desejar, uso teórico de um uso prático da razão. ${ }^{219}$

Como em Kant, o dever ser (sollen) aparece separado do ser - esse era o cerne, afinal, da crítica hegeliana, que persiste tanto em Marx como na teoria crítica "ortodoxa" (para usar o termo de Freyenhagen ${ }^{220}$ ). Entretanto, essa separação estrita entre uso teórico e uso prático da razão não ocorre em um livro como Conhecimento e Interesse, de 1968. ${ }^{221}$ Porém, no posfácio de 1973, quatro anos após a morte de Adorno, Habermas já busca prevenir leituras "equivocadas" de seu livro, respondendo a acusação de Krüger de que ele teria misturado "esforços da razão teórica com esforços da razão prática" e de que ele então afirmaria "uma ligação das ciências com a práxis no sentido de recusar 'a diferença, amplamente aceita, entre enunciados sobre fatos e recomendações ou instruções para a ação",222 . Se o acusado fosse Adorno ou Marcuse ou Bloch ou

\footnotetext{
${ }^{219}$ Jürgen Habermas, Verdade e justificação - ensaios filosóficos, p. 269.

220 "Access to the truth is not nonpartisan or interest-neutral, but rather is gained by a subject who has this interest: only in this way can we perceive the truth as truth." Fabian Freyenhagen, "What is Orthodox Critical Theory?" in world picture 12 (winter 2017).

${ }^{221}$ Isso é notável em passagens como: "A dissociação entre fatos e valores significa contrapor ao puro ser um dever abstrato." Habermas, Conhecimento e interesse, p. 181. Mais adiante há também afirmações como: "a verdade dos enunciados se funda na antecipação da vida bemsucedida [...] a unidade de conhecimento e interesse se confirma em uma dialética que, a partir dos sinais históricos do diálogo reprimido, recontrói aquilo que lhe foi negado." Ibid, p. 196.

${ }^{222}$ Habermas, Conhecimento e Interesse.
} 
Horkheimer $^{223}$ etc, a acusação seria tomada como elogio. ${ }^{224}$ No entanto, Habermas não pestaneja, e recusa a acusação (que não é totalmente descabida - afinal, Conhecimento $e$ interesse ainda é notadamente marcado pelo estilo e pelos pressupostos dos "velhos" frankfurtianos), e responde: “Ora, eu jamais neguei a diferença lógica entre afirmações (enunciados declarativos) e recomendações (enunciados normativos); pelo contrário, insisto em que afirmações devem ser fundamentadas em discursos teóricos, na forma de explicações, recomendações em discursos práticos, na forma de justificações. ${ }^{, 225}$ No lugar da verdade, entra o problema da validade e do direito ao reconhecimento intersubjetivo. A verdade passa a ser não mais algo do objeto, mas um consenso entre pessoas fundamentado sob "as condições inequívocas de uma situação ideal de fala, isto é, de uma comunicação desonerada das coerções da ação." Se outrora buscava-se o vínculo entre política e verdade, aqui (como em Foucault ${ }^{226}$ ) ele é declarado rompido. Toda a dimensão do desejo, dos anseios, da (falta de) liberdade tornam-se separadas da verdade e do pensamento, pois: “A verdade de uma proposição não pode ser medida pela satisfação de interesses, [...]" - algo oposto ao vínculo entre verdade e sofrimento proposto por Adorno e ao entre verdade e felicidade como aparece em Marcuse ${ }^{227}$ _ “[...] mas somente pelo resgate argumentativo da própria pretensão de validade. Justamente para separar com maior clareza o problema da constituição do sentido do problema de validade, eu tentei desenvolver uma teoria da verdade como consenso [...]." ${ }^{, 228}$ A validade

${ }^{223}$ Horkheimer remetia a unidade entre verdade e justiça a Marx: "No fundo, Marx considerava idênticos, como bom humanista, ambos conceitos (verdade e justiça). Nós também achamos isso, e justamente por isso, nessa discrepância (entre verdade e justiça), a sociedade parece se despedaçar." HGS 6, p. 264.

${ }^{224}$ Nunca é demais insistir que, no pensamento dialético, a relação entre teoria e prática (entre conhecimento e moral) não é de subordinação, isto é, não se "extrai" consequências práticas de um conhecimento verdadeiro, mas há uma tendência prática na própria verdade: "O pensamento dialético é fundamentalmente diferente do pensamento tradicional na medida em que não há nele um sistema teórico elaborado a partir do qual se extrai 'consequências práticas', depois de ter primeiro tranquilamente ter toda a teoria, mas ocorre de tal modo que em todas os níveis desse pensamento, poderíamos dizer, saem fagulhas que, do polo extremo da consciência teórica, inflamam o polo extremo da conduta prática." EiD, p. 55.

${ }^{225}$ Habermas, Conhecimento e interesse, cit., p. 483-4.

${ }^{226}$ Foucault, "Introdução a uma vida não fascista".

227 "Na teoria crítica, o conceito de felicidade não tem mais nada a ver com o conformismo e o relativismo burgueses: ele é uma parte da verdade universal, objetiva, valendo para todos os indivíduos, na medida em que todos os interesses destes estão aí preservados [aufgehoben]." Herbert Marcuse, Filosofia e teoria crítica, p. 189.

${ }^{228}$ Habermas, Conhecimento e interesse, p. 485-6. Que reapareça aqui filosoficamente a ideia de consenso, estruturante da vida política alemã do pós-guerra, não é um acaso. Na homenagem a Dahrendorf (citada anteriormente) nota-se também essa mudança de posição em relação ao liberalismo de mercado, que antes parecia "não ter cabimento" com aquele "traço antiutópico", mas depois, diz Habermas, a teoria do conflito gerenciado de Dahrendorf, um "adepto do 
da verdade recupera sua neutralidade como algo puramente constativo e próprio somente ao discurso teórico, enquanto que, do ponto de vista regulativo, o discurso prático se ocupa da validade da correção das normas, e o momento expressivo é avaliado do ponto de vista da veracidade daquilo que o sujeito fala, algo que diz respeito estritamente ao sujeito - o que não teria como estar mais distante da defesa de Adorno do momento expressivo da linguagem, uma vez que há uma "sedimentação" de verdade no sofrimento que é expresso enquanto "objetividade que pesa sobre o sujeito" 229 . Os três âmbitos da racionalidade, o estético-expressivo, o prático-moral e o cognitivo-instrumental aparecem agora de modo separado.

Habermas reduz a verdade, enquanto verdade proposicional, à correspondência aos fatos, isto é, à correção, enquanto para Horkheimer "o que é verdadeiro também é correto, mas nem de longe tudo que é correto é verdadeiro. ${ }^{\text {230 }}$ A correção de uma proposição é a mera reduplicação dos fatos, apartada da dimensão prático-moral, e por isso mesmo ela não tem uma relação necessária com a verdade tal como ela é compreendida na tradição dialética. E como já se há de ter percebido, por moral entendese todo esse âmbito da prática que passa pela política, pela liberdade, pelo desejo, pelo amor, pelo sofrimento e pela compaixão. Como diz Horkheimer: "A verdade depende de nossa vontade, da ação. Querer, conhecer e agir não são tijolos que podem ser empilhados de forma arbitrária, mas dependem um do outro." ${ }^{231}$ Separar da verdade esses momentos tende a sacrificar a própria verdade, o que equivale ao ideal positivista de eliminação da sensibilidade daquele que conhece no processo de conhecimento: "O cientista, se ele for meramente cientista, na verdade não percebe de modo algum uma série de coisas decisivas - como por exemplo o sentido de um rosto, o movimento interno de uma pessoa."232 Para aqueles que testemunharam a ascensão do complexo científicoindustrial-militar como núcleo duro da dominação no capitalismo tardio, não havia mais contexto para se enxergar qualquer potencial liberador na ciência feita nos laboratórios, que era, pelo contrário, complementar à máquina de guerra e à compulsão ao lucro. Se no berço da modernidade as ciências naturais foram armas contra a metafísica e as imagens religiosas de mundo, agora elas apareciam como plenamente imbricadas na dominação

esclarecimento, voltou a me arrebatar." Habermas, "Racionalidade de paixão. Ralf Dahrendorf em seu aniversário de 80 anos", p. 212.

${ }^{229}$ DN, p. 24.

${ }^{230}$ HGS 14, p. 209.

${ }^{231}$ Ibid.

${ }^{232}$ HGS 13, p. 106. 
(aliás, esse era o grande problema que Habermas precisou resolver ao ter que desfazer o imbróglio da crítica à razão instrumental, que não vou desenvolver aqui). No caso de Horkheimer, esse lado "afetivo" do conhecimento, eliminado pelo ideal positivista de método, aparece ainda na sensibilidade para se enxergar a fisionomia humana: "Ver um rosto corretamente - isso é verdade." 233

No limite, a verdade como correção não passa de tautologia: troca-se igual por igual e ficamos na mesma. O aforismo Intellectus sacrificium intellectus da Minima Moralia dá notícia disso: "Tão logo esteja apagado o último traço de emoção, só resta ao pensamento a tautologia absoluta." 234 A retirada de cena das emoções no processo de conhecimento não tem outra consequência senão o emburrecimento: "o pensamento que mata o desejo, seu pai, é alcançado pela vingança da tolice." ${ }^{235}$ Subtraída a dimensão afetiva da verdade, o resto é aquilo que é: a pura logicidade do presente. O não-presente, seja o passado, seja o futuro, torna-se inconcebível: "Não será a memória inseparável do amor, que busca preservar o que no entanto se vai? Não será todo movimento da imaginação engendrado pelo desejo, que vai além do existente sem traí-lo ao deslocar seus elementos?"236

No entanto, podemos dizer que nesse anseio anacrônico pela verdade há uma certa melancolia, pois em sua efetiva irrelevância para a ciência praticada há uma verdade histórica, ou seja: o declínio da verdade é um sintoma de época. A reduplicação dos fatos na consciência e a atrofia da imaginação é a anulação da possibilidade de que aquilo que ainda não é venha a ser - há uma derrota da verdade. Como toda ideologia, também o positivismo possui seu teor de verdade: a anulação do tempo nos fatos diz respeito a uma nova experiência histórica. Horkheimer já notava isso ao escrever o fragmento "A verdade do positivismo". O declínio do conceito de verdade corresponde ao declínio das expectativas históricas, ou mais diretamente, ao declínio da utopia:

\footnotetext{
${ }^{233}$ HGS 14, p. 261.

${ }^{234}$ MM, p. 119.

${ }^{235}$ MM, p. 118. Essa ideia do desejo como pai do pensamento reaparece na Dialética Negativa: "Desde Xenófanes, o fato de o desejo ser um mau pai do pensamento é uma das teses gerais do Esclarecimento europeu [...].” DN, p. 327. Até onde sei, tal motivo freudo-nietzscheano aperece exatamente nesses termos em Brecht: uma das Histórias do Sr. Keuner chama-se precisamente "A paternidade do pensamento", e ali ele diz: "O Sr. K. ouviu a censura de que, no seu caso, com frequência o desejo era o pai do pensamento. Ele então respondeu: 'Nunca houve um pensamento cujo pai não fosse um desejo. O que se pode discutir é: que desejo? Não é preciso suspeitar que uma criança não tenha pai, para suspeitar que a determinação da peternidade seja difícil."” Brecht, Histórias do Sr. Keuner, p. 48.

${ }^{236}$ MM, p. 118.
} 
O positivismo corresponde à conjuntura depois da Segunda Guerra Mundial. Nem os de cima nem os trabalhadores querem outra coisa senão o existente; a fantasia que se produz a partir da filosofia não possui por isso força alguma. [...] A satisfação com aquilo que é não provém meramente da vontade paralisada, mas do sentimento de que nada mais virá [...]. A história europeia acabou e por isso o positivismo tem razão, não há nenhum refúgio que não a maquinaria. Todos os conceitos que não se deixam reduzir aos fatos são insignificantes. ${ }^{237}$

\section{Exagerar é preciso: verdade e linguagem}

Até onde vai a autorização moral de dar ouvidos a esses convites à imoderação?

Kant, Metafisica dos costumes

Somente o exagero é verdadeiro.

Adorno \& Horkheimer, Dialética do Esclarecimento

A ideia de que os fatos, que deveriam ser neutros, são falsos e que a verdade possui uma relação negativa com aquilo que é (e que, portanto, algo da verdade diz respeito ao que não é, extrapolando o conhecimento das coisas como elas são e que só é verdadeiro aquele pensamento que deseja a transformação do existente em algo totalmente outro) parece algo exagerado: não obstante, nada é mais preciso. A verdade que extrapola os limites dados aparece necessariamente sob a figura do exagero ${ }^{238}$ : “É-lhe [ao pensamento] essencial um elemento de exagero, do ir além da coisa, de liberar-se do peso do fático, graças ao qual executa de modo simultaneamente rigoroso e livre a determinação do ser ao invés de ficar na sua mera reprodução." 239 Na Minima Moralia, a própria dialética aparece como um exagero ${ }^{240}$, e sua verdade consiste na sua capacidade de romper o

\footnotetext{
${ }^{237}$ [grifos meus] HGS 6, p. 314.

238 Isso aparece já no excurso sobre Juliette na Dialética do Esclarecimento: "Enquanto os escritores luminosos protegiam pela negação a união indissolúvel da razão e do crime, da sociedade burguesa e da dominação, aqueles [escritores sombrios da burguesia] proferiam brutalmente a verdade chocante [grifo meu]. '...É nas mãos sujas pelo assassinato das esposas e dos filhos, pela sodomia, pelos homicídios, pela prostituição e pelas infâmias que o céu coloca essas riquezas; e para me recompensar por essas abominações, ele as põe à minha disposição', diz Clairwill no resumo da vida de seu irmão. Ela exagera. A justiça da má dominação não é consequente a ponto de recompensar apenas as atrocidades. Mas só o exagero é verdadeiro." Dialética do Esclarecimento, p. 97

${ }^{239}$ MM, p. 123.

${ }^{240}$ Há que se fazer uma breve nota sobre uma pequena diferença de conotação entre "exagerar" e "übertreiben". Enquanto "exagerar" conota sobretudo falseamento, em übertreiben está contido
} 
"sense of proportions" do entendimento moderado. ${ }^{241}$ Não exagerar implica ficar na aparência: "Todo pensamento que atravessa [durchschlägt] a fachada, a aparência necessária, a ideologia, é sempre exagerado [überspitzt]. A inclinação da dialética de ir aos extremos tem exatamente a função de resistir contra a imensa pressão exterior., ${ }^{, 42} \mathrm{O}$ exagero constitui sempre um excesso, uma desmedida - assim se diz por exemplo de um sujeito que bebeu exageradamente - e esse excesso produz uma pane no organismo. Não por acaso, a crise do capitalismo em Marx (e o próprio capital fictício, que já é crise) aparece como uma desmedida do valor. ${ }^{243}$ Ou seja, há uma dimensão da realidade que escapa à mensuração e à moderação (ou quando a própria proporção aparece como doente $^{244}$ ) e ela só pode aparecer na linguagem sob a figura do excesso. O crítico exagera - mas o exagero já está na realidade: a crise é o exagero objetivo. O exagero da realidade está em sua própria tendência de romper com sua aparência, e aquele que o anuncia aparece como profeta ou louco - ou "bobo da corte", como na figura medieval do $\operatorname{Narr}^{245}$ : "vale hoje como nos tempos medievais que só os loucos [Narren] dizem a verdade aos poderosos." 246

A figura do exagero torna-se tanto mais verdadeira quando a verdade assume o caráter de urgência. Günther Anders, ao falar sobre a Bomba (que, enquanto um objeto “superliminar", é em si uma desmedida que escapa à nossa capacidade de imaginação), assume na linguagem exagerada a figura do profeta, ao mesmo tempo tão próxima do Narr, pois em seu caso a verdade sobre a Era Nuclear deve soar alto como um alarme. ${ }^{247}$

mais fortemente essa ideia do excesso, do além da conta, tendo inclusive como sinônimo "ir longe demais" - inclusive, tal era o sentido original da palavra do alto-alemão médio (zu weit treiben), como consta no Duden Universalwörterbuch. Günther Anders, outro exagerado, brinca com a palavra, referindo-se à necessidade de exagerar frente a uma Untertreibung (minimização, subexageração). Anders com frequência joga com os prefixos über- e unter-, formando a palavra "superliminar" (überschwellig), como aquilo que é grande demais para que seja percebido, em oposição ao freudiano "subliminar" (unterschwellig). Da mesma forma, quando ele escreve sobre o piloto de Hiroshima Claude Eatherly, por ser capaz de arrepender-se daquilo que ele havia somente "participado" (mitgemacht), ele "assume" (übernehmen) aquilo que não exatamente ele "leva a cabo" (unternehmen). Anders, Hiroshima ist überall, cit., p. XIX.

${ }^{241}$ Para uma discussão sobre a célebre porém pouco discutida frase da Minima Moralia de que "na psicanálise somente seus exageros são verdadeiros", ver a dissertação de Bruno Carvalho "Psicanálise e crítica social em Adorno". Dissertação de mestrado, Universidade de São Paulo, 2016.

${ }^{242}$ EiD, p. 11.

${ }^{243}$ Cf. Jorge Grespan, O negativo do capital.

244 "Uma vez tendo reconhecido a generalidade dominante e suas proporções como doente [...]." MM, p. 68.

${ }^{245}$ Também em francês o bobo da corte é "o louco do rei”: le fou du roi.

${ }^{246}$ MM, pp. 68-69 (tradução modificada).

${ }^{247}$ Já em textos de juventude como o Patologia da liberdade, muito marcado pela fenomenologia 
A verdade do exagero aparece nessa Parábola de Noé, onde exagerar aparece como uma exigência comunicativa da linguagem - entenda-se comunicativo não como o entendimento mútuo habermasiano, mas como o meio de fazer o outro sair de sua apatia intelectual e moral, instigar a imaginação de seus contemporâneos, amedrontá-los ${ }^{248}$ :

Noé estava cansado de fazer o papel dos profetas da desgraça e de sempre anunciar uma catástrofe que não acontecia e que ninguém levava a sério. Um dia, ele se vestiu com um saco velho e jogou cinzas sobre a cabeça. Este gesto só era permitido àquele que chorava por um filho querido ou pela esposa. Vestido com o traje da verdade, ator da dor, ele voltou para a cidade, decidido a colocar a seu favor a curiosidade, a maldade e a superstição dos habitantes. Logo ele reuniu à sua volta uma pequena multidão curiosa, e as questões começaram a aparecer. Perguntaram a ele se alguém havia morrido e quem era a pessoa morta. Noé lhes respondeu que muitos estavam mortos e, para grande divertimento dos seus ouvintes, ele lhes disse que os mortos eram eles mesmos. E, quando lhe perguntaram quando esta catástrofe tinha acontecido, ele respondeu: amanhã. Aproveitando-se então da atenção e da confusão, Noé ergueu-se em toda sua grandeza e se pôs a falar: depois de amanhã o dilúvio será alguma coisa que terá sido. E quando o dilúvio tiver sido, tudo o que é não terá jamais existido. Quando o dilúvio tiver levado tudo o que é, tudo o que terá sido, será tarde demais para lembrar porque não existirá mais ninguém. Então não haverá mais diferença entre os mortos e os que os choram. Se eu vim diante de todos foi para inverter o tempo, para chorar hoje os mortos de amanhã. Depois de amanhã será tarde demais. Com isso, ele voltou para casa, tirou seus trajes, limpou a cinza que lhe cobria o rosto e foi para a oficina. À noite, um carpinteiro bateu à sua porta e disse: deixe-me ajudá-lo a construir a arca, para que isto não se torne verdadeiro. Mais tarde, um telhador se juntou aos dois dizendo: chove sobre as montanhas, deixem-me ajudá-los para que isso não aconteça.

e pela ideia de uma antropologia filosófica, Anders já apontava a verdade do exagero e sua adequação a situações de exceção, isto é, à contingência: "Cependant ce que nous nommons 'exagération philosophique' ne constitue nulle falsification [...]. L'exagération provient de ce que les énoncés ne sont en principe exprimés qu'en des situations d'exceptions, que d'autre part certaines formulations achèvent et précisent des états effectifs, et ne les conduisent qu'ensuite à leur effective vérité. Ce qui est 'exagéré', c'est-à-dire poussé à un maximum d'acuité et à une vérité sans fard, est en premier lieu la situation de contingence elle-même, et en second lieu seulement l'énoncé dont elle est l'objet. Les formulations ne sont pas seulement donc expression de cette existence mais elles l''informent' : de telle sorte qu'elles deviennent vraies." Anders, Pathologie de la liberté: essai sur la non-identification. Recherches philosophiques, volume VI, pp. 22-54.

${ }^{248}$ Essa parábola é parte do texto "Die beweinte Zukunft" (1961), publicado no volume Die atomare Drohung: radikale Überlegungen zum atomaren Zeitalter, que originalmente foi publicado em 1972 sob o título Endzeit und Zeitenende: Gedanken über die atomare Situation. A citação aqui é um trecho recortado desse texto e está traduzida no ensaio de Jean-Pierre Dupuy "Chorar as mortes que virão - por um catastrofismo ilustrado" in: Adauto Novaes (org.). O futuro não é mais o que era. São Paulo: Edições Sesc, 2013. 
Jean-Pierre Dupuy cita este trecho de Anders não para pensar a latência real da catástrofe nuclear, mas para pensar uma filosofia da catástrofe "em geral”. O colapso econômico, social e ecológico que passa a ser vivido como algo já presente na segunda metade do século XX, resultado de uma crise estruturalmente intransponível da acumulação capitalista ${ }^{249}$, dá um outro aspecto ao imaginário escatológico. Dito de outro modo: "é somente a partir do momento em que o fim iminente se converte em fim imanente que o Apocalipse torna-se 'um mito da Crise', produzido como uma passagem sem fim ${ }^{250}$. No caso do alerta de Noé, na parábola de Anders, a verdade do exagero como a lupa de aumento temporal visa detectar o futuro como tendência, potência real do presente: no caso, o fim do mundo, que (mais uma vez invertendo Bloch) ainda não ocorreu. Essa lupa de aumento do exagero depende da fantasia objetiva, que é "a capacidade de empurrar [treiben] as possibilidades para o extremo, de modo que elas possam ser vistas e analisadas de forma mais clara." ${ }^{251}$ O exagero da fantasia objetiva traz para perto aquilo que está presente somente enquanto latência e possibilidade. Por esse caminho, Bloch enxerga a verdade da arte em seu elemento fabulativo: "a exageração e a fabulação representam uma importante pré-aparência do real, que circula no próprio existente em movimento [...]." ${ }^{, 252}$ Há igualmente um caráter de exagero na antecipação inerente aos "afectos expectantes":

Em todos os afectos expectantes, a intenção indica para a frente, o contexto temporal de seu conteúdo é o futuro. [...] Assim, também intenções expectantes com conteúdo negativo em relação à autopreservação, como angústia e medo, podem se tornar uma paixão, não menos que a esperança. Nesse caso, elas parecem exageradas a quem não está envolvido e de fato o são em casos patológicos. Todavia, às vezes é a falta de conhecimento a

\footnotetext{
${ }^{249} \mathrm{Tal}$ argumento é fundamentado por autores como Robert Kurz, que enxergaram como, a partir da terceira revolução industrial, houve um avanço tal do nível das forças produtivas que desencadeou uma crise do trabalho abstrato como fundamento da produção de valor e da acumulação capitalista, de modo que a financeirização (acumulação fictícia) é não causa, mas consequência de uma crise anterior: o próprio bater com a cabeça no teto lógico do limite absoluto. Algo que no entanto não leva a uma superação automática: o teto histórico é vivido como catástrofe permanente, não como crise desencadeadora de futuro (tal como o termo "crise" aparece na filosofia da história em torno da Revolução Francesa, segundo o já citado estudo de Reinhardt Koselleck, Crítica e Crise).

${ }^{250}$ Éric Hoppenot, De l'Apocalypse à Amalek. Esquisse d'une réflexion sur la pensée du mal dans l'oeuvre de Maurice Blanchot. in: Maurice Blanchot et la philosophie. Presses universitaires de Paris Nanterre, 2010, p. 157-178.

${ }^{251}$ Silvia Mazzini, "Objektive Phantasie" in Bloch-Wörterbuch, p. 425-426.

${ }^{252}$ PE, p. 212.
} 
respeito da situação real que as faz parecerem exageradas, aumentando o seu objeto. ${ }^{253}$

Porém, no lugar da consciência antecipatória blochiana da utopia, temos em Anders o lado B da escatologia: a consciência antecipatória do desastre (se é que desastre é uma palavra adequada para Apocalipse Nuclear). Mas há de se notar um aspecto nessa antecipação. Como observa Dupuy, "o acontecimento catastrófico está inscrito como um destino, é certo, mas também como um acidente contingente." 254 O anúncio da catástrofe é verídico, mas não é uma previsão. Seu paradoxo está no seu caráter performativo: a finalidade da enunciação exagerada é impedir a sua realização, para a qual o curso do mundo tende. Assim como anunciar a utopia, antecipando-a, deve ter o efeito de produzi$l a$, o anúncio da catástrofe deve ter o efeito de evitá-la. A força da verdade na linguagem é a união entre o que nela há de performativo, instituinte, e o que há de representação adequada ao objeto: um conhecimento que esteja à altura do presente não é, por isso, "mera representação". O verdadeiro realismo não é a simples duplicação da realidade: há nele um momento produtivo. O Alarme de incêndio de Walter Benjamin é igualmente uma antecipação performativa ao indicar que, para a ação correta, é necessária a imaginação da explosão (ainda não atual) que configura o perigo presente: "Antes que a centelha chegue à dinamite, é preciso que o pavio que queima seja cortado." ${ }^{, 255}$ A profecia da desgraça, como afirmou Hans Jonas, "é feita para evitar que ela se realize; e zombar posteriormente dos eventuais sineiros de alarme dizendo a eles que o pior não aconteceu

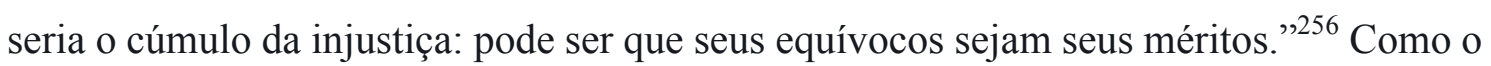
futuro carece de existência sensível imediata, a profecia deve necessariamente ir além dos fatos presentes: por isso ela é sempre um exagero. Isso se expressa mesmo na relação com o clima nas sociedades onde a cientifização completa da metereologia não banalizou profecias como "amanhã vai chover" 257.

\footnotetext{
${ }^{253}$ PE, p. 109-110. Bloch compara ainda essa as formas de antecipação do medo e da esperança: "Todo medo implica, como correlato da realização, aniquilação total, que dessa forma ainda não existiu, o inferno irrompendo. Toda esperança implica o bem supremo, a bem-aventurança irrompendo, que dessa forma ainda não existiu." Ibid.

${ }^{254}$ Dupuy, cit., p. 202.

${ }^{255}$ Walter Benjamin, Rua de mão única, p. 46.

${ }^{256}$ Hans Jonas, O princípio responsabilidade: uma ética para a civilização tecnológica (apud Dupuy, cit., p. 200)

${ }^{257}$ Objeto de estudo da antropologia por exemplo em Renzo Taddei, Metereologistas e profetas da chuva: conhecimentos, práticas e políticas da atmosfera. São Paulo: Terceiro Nome, 2017.
} 
Ainda em torno de Anders: o exagero é então uma exigência linguística colocada por um objeto cuja dimensão real seria já falsificada por uma descrição simples, imediatamente realista: daí também a verdade estética das inversões de Kafka, Beckett e Brecht $^{258}$. Ao tentar descrever a Bomba, Anders diz que "objetos trivializados exigem formulações exageradas":

'Simplesmente descrever' um tal objeto é naturalmente impossível. Quando pertence essencialmente à situação de um objeto que ele seja obscurecido ${ }^{259}$, trivializado ou recalcado, então cabe inversamente à sua exposição - isso constitui sua verdade - reparar esse obscurecimento [Verundeutlichung] e exagerar [übertreiben] o contorno tanto quanto ele normalmente é "sub-exagerado"[untertrieben.$^{260}$

A função do exagero aqui é política: "atingir o ouvido do outro". Anders diz: "Este então o motivo para o hiper-afio ${ }^{261}$ de minhas formulações. O tempo feliz, no qual se pode dar ao luxo de não hiper-afiar ${ }^{262}$ [überspitzen], de não exagerar [übertreiben]: o tempo da simplicidade, nós ainda não o alcançamos." 263 Tal responsabilidade política impede que o exagero seja a produção de uma espécie de frisson estético com a ideia do fim do mundo, que produziria somente um gozo cínico diante da barbárie. ${ }^{264} \mathrm{O}$ emprego ético e gnosiológico do exagero em Anders é próximo da linguagem de Adorno, que produz nos leitores também uma sensação de choque moral. Como comenta J. M. Bernstein na primeira linha de seu Disenchantment and Ethics, "readers of Adorno are inevitably struck by how everything he wrote was infused with a stringent and

\footnotetext{
${ }^{258}$ Günther Anders sobre as inversões: "Quando Esopo ou Lafontaine queriam dizer: as pessoas são como animais - eles mostravam pessoas como animais? Não. Mas sim trocavam - e nisso consiste o efeito de estranhamento propriamente divertido das fábulas - ambos elementos da equação; isso significa: eles afirmavam que os animais seriam pessoas. Brecht fez o mesmo há um quarto de século, quando ele, na 'Ópera dos Três Vinténs', queria contar: burgueses [Spießer] são ladrões; também ele fez do sujeito o predicado e vice-versa, apresentou então ladrões como burgueses." Günther Anders, Antiquiertheit des Menschen I, p. 215.

259 Anders emprega aqui o neologismo verundeutlicht, que pode ser lido como antônimo de verdeutlicht, elucidado.

${ }^{260}$ Günther Anders, Antiquiertheit des Menschen I, p. 236.

${ }^{261}$ Outro neologismo: "Überpointiertheit", derivado de pointiert, que poderia ser traduzido como afiado, preciso, certeiro (tais metáforas cortantes e perfurantes também aparecem no título do livro de Adorno Stichworte, alusão ao verbo stechen).

${ }^{262} \mathrm{O}$ termo é überspitzen, que significa correntemente exagerar, mas deriva também de spitzen (afiar, apontar, aguçar).

${ }^{263}$ Günther Anders, Antiquiertheit des Menschen I, p. 237.

264 Observaram certa vez que uma das perguntas de um questionário de um site de relacionamentos utilizado para produzir matches era se a ideia de uma guerra nuclear poderia ser, de algum modo, interessante.
} 
commanding ethical intensity. $" 265$ As frases abruptas, sem conectores e com uma sintaxe sufocante, a mediação pelos extremos, os parágrafos longos, tudo isso atordoa o leitor. Mas, conforme Adorno defende em seu programático $O$ ensaio como forma, trata-se de tentar, na linguagem, fazer justiça ao objeto em sua "primazia". ${ }^{266}$ Tal primazia do objeto exige na prosa adorniana não somente exageros, mas, como o mundo não se permite descrever na linguagem "clara e distinta”, há uma inevitável obscuridade. ${ }^{267}$ Algo que não ocorre em Anders, ao menos não da mesma forma (há ali ainda um encanto do narrador - cabe lembrar que Anders possui uma vasta obra literária). Em uma carta um tanto ressentida de Anders a Adorno de 1963 (Anders lamenta que, apesar da proximidade do trabalho de ambos, eles nunca tenham sido de fato próximos), há uma cobrança direta de postura política frente aos diversos momentos em que "as coisas esquentaram", a que Adorno responde: "Certamente eu me silenciei frente a certas coisas abomináveis. Mas não sou nenhum policial de trânsito, que tem que estar imediatamente em todo canto onde se comete um delito." ${ }^{268}$ Entretanto, o mais inconformista dos intelectuais de sua geração, crítico do falso consolo e do conforto, para quem "faz parte da moral não se sentir em casa na própria casa" ${ }^{269}$, parecia, para Anders, ter se acomodado após o retorno da

${ }^{265}$ J. M. Bernstein, Disenchantment and Ethics, p. xi.

${ }^{266} \mathrm{O}$ texto de juventude Thesen über die Sprache des Philosophen já mostra pontos cruciais da concepção adorniana sobre a linguagem.

${ }^{267}$ Adorno aponta em seus Três estudos sobre Hegel a relação entre a obscuridade linguística hegeliana (ele assume que de fato há passagens absolutamente incompreensíveis em Hegel) e a obscuridade do prório real.

${ }^{268}$ Adorno - Eine Bildmonographie, p. 281. Apesar de modesta, há de se salientar as manifestações públicas de Adorno, tais como as de 1967, em torno caso Kurras, e de 1968, contra as leis de exceção, o que contraria o clichê conveniente de Adorno como um intelectual enclausurado. Ver: "Fora da torre de marfim - três textos de intervenção de Theodor W. Adorno" in: Revista Cult, N. 215, agosto de 2016.

${ }^{269}$ MM, p. 35, trad. modificada. Aliás, uma impressão que os discípulos de Adorno em geral passaram a partir dos anos 1970, a saber, a de que ser filósofo seria a vida correta na falsa. Sobre Adorno enquanto "inimigo de Estado na cátedra de ensino" (lembremos que na ressaca pós-1968, no período dos ataques da RAF [Rote Armee Fraktion], Adorno foi acusado na televisão de ser o "autor espiritual do terrorismo") e a acomodação da filosofia adorniana na vida acadêmica alemã, ver Wolfgang Pohrt, "Der Staatsfeind auf dem Lehrstuhl". Vale notar que, ao contrário da recepção de Adorno no resto do mundo, que se deu, até onde sei, pela via acadêmica, há uma peculiaridade alemã que o torna um autor ainda vivo em espaços políticos tais como entre anarquistas em ocupações urbanas, para quem a teoria adorniana ressoa no imaginário antifascista e anti-capitalista, para além do interesse teórico mais restrito. Isso remete ainda ao período pré-68, quando aquela mensagem na garrafa lançada ao mar dos antigos frankfurtianos foi encontrada por jovens da esquerda radical. Várias dessas obras estavam fora de circulação devido a edições esgotadas, e eram redescobertas por uma juventude de esquerda (alguns vinculados à SDS [Sozialistischer Deutscher Studentenbund], da qual Krahl, o orientando de Adorno que foi liderança estudantil em 1968, fazia parte), que fazia cópias piratas de textos como a Dialética do Esclarecimento, O Estado Autoritário, entre outros. No final dos anos 50, pouco depois da fundação da revista konkret, Ulrike Meinhof entra em contato com Adorno para que publicassem 
emigração: "É difícil de reprimir a impressão de que você, reconhecido como papa oficial da radicalidade, de algum modo tenha caseiramente se acomodado na ominosa e deplorável República Federativa Alemã. ${ }^{270}$ A crítica de Anders a Adorno abrange uma crítica estilística e chega ao ponto de uma acusação (exagerada) de sadismo literário:

Por outro lado, nesta ascese da ação, cai-se facilmente na tentação de vingar-se no público. Você sabe que eu não sou exatamente insensível do ponto de vista estilístico. E eu creio que é possível sentir em seu estilo o tom de vingança, de desprezo, de violação [Vergewaltigung]. Você por exemplo não permite [missgönnen] a tomada de fôlego aos seus leitores por meio da falta de pausas [Fermatelosigkeit] de seus textos, por meio da evitação categórica de novos parágrafos; você o força adiante, apesar de ele precisar se arrastar em ritmo de lesma diante da dificuldade (objetivamente legítima) da sua linha de pensamento. Você o puxa para dentro dos corredores, que, como ele não dispõe da sua visada, parecem-lhe necessariamente labirínticos (na verdade eles não o são, a não ser que eles retratem um contexto labiríntico) em suma: com frequência tenho a impressão de que esse estilo apresenta um tipo de ação de vingança. Como você abdicou da ação política ou da participação na oposição política real, você tenta produzir com meios linguísticos algo parecido com a ação, ao menos infligir algo no leitor. - O nexo com o "terrorismo", do qual eu há pouco falava, é claro. Pois ao mesmo tempo você parece querer punir seus leitores, afinal eles estão sempre abaixo de você, basicamente são os leitores errados. Sadismo literário. ${ }^{271}$

A preocupação de Anders com o leitor e a comunicação mostra, ao menos nesse quesito, sua adesão à estética didática de Brecht (que Anders também não poupou de críticas severas, apesar da amizade entre ambos ${ }^{272}$ ). É evidente que tal preocupação não

na revista o capítulo da Dialética do Esclarecimento sobre indústria cultural, o que termina em um imbróglio, pois Horkheimer era contra a publicação. Cf. troca de cartas entre Adorno e Ulrike Meinhof, TWAA.

${ }^{270}$ Anders diz a Adorno que não se pode viver como "um conselho secreto surrealista [ein surrealistischer Geheimrat]". A metáfora vanguardista é adequada, e é exatamente tal existência contraditória que é pensada por ambos nessas cartas. (Lembremos daquele "um pé do contra, outro a favor" que Antonio Candido via nos modernistas paulistas. Cf. Paulo Arantes, Da noite para o dia, p. 139). O que entra na discussão entre Anders e Adorno (e isso passa por todo o debate adorniano em torno das antinomias da participação) é "o pé a favor". Tal contradição, de ser ao mesmo tempo contra e a favor, parece a princípio impedir um tipo de engajamento, que, como diz Merleau-Ponty, é análogo ao princípio de não-contradição: "Descartes dizia que não se pode fazer e não fazer algo ao mesmo tempo, e é sem dúvida assim que Sartre entende o engajamento [...]." Maurice Merleau-Ponty, As aventuras da dialética, p. 256.

${ }^{271}$ Adorno - Eine Bildmonographie, p. 277.

${ }^{272}$ Me refiro a um texto que, pela forma da crítica, também poderia se chamar "Brecht: pro e contra". O ensaio leva o nome do livro analisado, "Geschichten vom Herrn Keuner (1979)" in 
torna o texto de Anders em alguma medida "fácil”, mas há uma preocupação militante de “destecnicizar" o pensamento ${ }^{273}$ e uma crítica do "ideal filosófico da dificultação [das philosophische Ideal des Schwermachens]",274, que pressuporia um "desprezo pelo próximo" 275 - na sociedade concorrencial, isso torna-se regra. O fato de Anders, assim como Bloch, usar tão frequentemente os pronomes "nós" e "nosso" faz com que o leitor

Günther Anders, Mensch ohne Welt. Schriften zur Kunst und Literatur. München: Beck, 1993, pp. 159-174.

${ }^{273}$ Isso se explicita no próprio fato de Günther Anders não ter seguido uma carreira acadêmica e ter tido uma atividade de escritor paralela à universidade. Há ainda um pequeno livro, no qual Anders trata sobre a linguagem filosófica, intitulado "Sobre a dicção filosófica e o problema da popularização".

${ }^{274}$ Anders fala da dificuldade do texto adorniano também em uma carta a Bloch: "Você já viu o novo livro do Adorno sobre Mahler? O que eu entendi dali, que é certamente só um porcento, é excelente; mas eu não entendo, para quem ele escreve, pois em nossos dias ele não pode contar com tantos Adorni e Adornamentos inteligentes enquanto leitores." Carta de Anders a Bloch, 28/11/1960, Günther-Anders-Archiv. Jean Améry, outro escritor e teórico da época (admirado por Adorno, inclusive), cultivava, assim como Anders, um estilo "destecnicizado" e mais literário, e em 1967 escreveu um texto criticando a transformação da dialética em jargão (o alvo, no caso, era a própria Dialética Negativa de Adorno). Apesar do texto incorrer em equívocos a respeito da dialética, há ali uma discussão interessante acerca da "anti-banalidade" de Adorno, ao mesmo tempo em que ele defende o elemento banal como parte daquilo que é prosaico (e não elevado) na dialética. Em sua crítica, aparece igualmente o problema do endereçado: "O jargão da dialética alienou-se não só do povo, mas também da maioria dos intelectuais. No lugar dos terribles simplificateurs entram os não menos terríveis complicadores: amanhã eles irão definhar na consaguinidade espiritual, se eles não estiverem preparados a assumir o risco daquilo que eles chamam hoje de 'banalidade'. [...] O esclarecimento crítico encontra-se em um ponto em que ele só pode se mostrar efetivo socialmente se ele se desintoxicar linguisticamente." Jean Améry, "Jargon der Dialektik", Merkur 21(236), 1967, p. 1059. Uma resposta a Améry, em defesa de Adorno, foi escrita por Ulrich Sonnemann em "Jargon der Dialektik?", Merkur 22 (240), 1968 (com uma réplica de Améry).

${ }^{275}$ Günther Anders, Die Antiquiertheit des Menschen I, p. 237. Não há como não lembrar do desprezo do sr. Keuner (ele mesmo um filósofo moral em tempo integral) pelo saber professoral: "Um professor de filosofia foi ao sr. K. e lhe falou de sua sabedoria. Depois de um momento, o sr. K. lhe disse: 'Você está sentado de modo incômodo, fala de modo incômodo, pensa incomodamente.' O professor de filosofia se irritou e disse: 'Não era sobre mim que eu queria saber, mas sobre o conteúdo do que falei.' 'Não tem conteúdo', disse o senhor K. 'Vejo que anda grosseiramente, e não há objetivo que alcance ao andar. Você fala obscuramente, e nada esclarece ao falar. Vendo sua postura, não me interessa o seu objetivo." Bertolt Brecht, Histórias do sr. Keuner, p. 11. Aliás, o Sr. Keuner, segundo Anders, tem também uma teoria da verdade com uma primazia da prática, visando uma verdade gestual da atitude: "Keuner era o fundador de uma teoria do conhecimento completamente nova. Pois para ele a verdade não consistia na identidade entre 'res' e 'intellectus', mas entre 'res' e 'atitude'. Quando alguém "senta de modo incômodo, fala de modo incômodo, pensa de modo incômodo", então Keuner não acreditava em uma palavra que lhe dissessem. 'Vendo sua postura, não me interessa o seu objetivo.' Postura era então para ele o critério veri et falsi; verdade gestual valia mais que a verdade das palavras: a saber, porque gestos se denunciam mais que palavras; ou seja, denunciam se falam a verdade ou se mentem. Por esse motivo, Br. interessava-se tão ardentemente por atores: eles tinham suas 'verdades' - e por meio disso eles podiam se provar - fazer-se crível por meio da postura e gestos... uma teoria terrivelmente perigosa: pois, que mentiras podem ser representadas com tal expressão induvidável de veracidade, isso Brecht deveria saber pelos nacional-socialistas honestos." Anders, "Geschichten vom Herrn Keuner", Mensch ohne Welt, p. 166. 
se sinta próximo do autor (ao passo que, em Adorno, quase sempre a ideia de coletividade aparece somente sob a marca da regressão). No caso de Adorno, como a crítica de fato parece não mais ter um endereçado determinado (ela era uma "mensagem na garrafa lançada ao mar"), o leitor sai de cena e a preocupação estilística é sobretudo voltada ao objeto (algo completamente distante da noção sartriana de engajamento literário, visto que, como se lê em $O$ que á a literatura?, a discussão sobre a relação com o leitor ocupa um lugar central). A acusação de violência vingativa contra o leitor obviamente não é aceita por Adorno: “Agora, daquilo que você escreve sobre a minha linguagem, confesso sinceramente que só muito dificilmente consigo imaginar que você esteja falando sério. A sua argumentação testemunha uma verdadeira obsessão com o leitor. Nos meus textos você claramente não chegou a pensar que não se trata nem de apanhar o leitor nem de afrontá-lo, mas somente da apresentação ao máximo adequada e rigorosa da coisa. Isso é a única coisa que possa se fazer seriamente contra a indústria cultural." ${ }^{276}$

A distância entre o escritor e o leitor nasce de uma separação entre a objetividade da crítica na linguagem e seu teor inter-subjetivo e comunicativo: "cuidar da comunicação" seria uma "traição ao comunicado". No fragmento "Moral e estilo" da Minima Moralia, Adorno já considerava as acusações de hermetismo em relação à sua prosa amarrada e obscura:

Sabem os escritores que quanto mais a expressão é precisa, cuidadosa, adequada ao objeto, tanto mais o resultado literário é tido como de difícil compreensão, ao passo que a formulação frouxa e irresponsável tem por recompensa um certo entendimento [...]. O negligente abandonar-se à corrente usual da fala sinaliza pertencimento e contato; sabe-se o que se quer porque se sabe o que o outro quer. Exprimir-se olhando mais para a coisa do que para a comunicação é suspeito: o que é específico e independe dos esquemas dados é tomado como falta de consideração, como sintoma de esquisitice, quase de confusão. [...] Somente aquilo que não exige compreensão parece compreensível; só o verdadeiramente alienado, a palavra cunhada pelo comércio, $[. .$.$] toca como familiar. { }^{277}$

$\mathrm{O}$ ataque à linguagem comunicativa como língua de comerciante, como "palavra cunhada pelo comércio", vem de Mallarmé, que anunciava em Crise de vers: "Falar se relaciona com a realidade das coisas somente comercialmente: em literatura, isso se contenta em fazer uma alusão a ela ou em subtrair sua qualidade que incorporará alguma

\footnotetext{
${ }^{276}$ Adorno - Eine Bildmonographie, p. 182.

${ }^{277}$ MM, p. 97 (tradução modificada).
} 
ideia." ${ }^{278}$ No auge do iluminismo, comunicação e comércio se confundiam efetivamente: o comércio era sinônimo de entendimento humano no mais progressista dos sentidos. No verbete Commerce da Enciclopédia de Diderot e D'Alembert, a primeira definição esclarece isso: "On entend par ce mot, dans le sens général, une communication réciproque." 279 No limite, se nos for permitido exagerar (com precisão), a utopia comunicativa de Habermas visa realizar a utopia comercial iluminista. ${ }^{280}$ Para Adorno, na esteira de Mallarmé ${ }^{281}$, participar da comunicação é participar de uma eticidade corrompida pela lógica da troca de equivalentes: ou seja, a linguagem anti-comunicativa é o próprio nicht mitmachen adorniano formalizado no estilo, daí a relação entre linguagem e política e o fundamento da crítica estilística de Anders a Adorno.

Seria falsa a alternativa entre a redução mallarmaica à pura materialidade opaca da palavra e a transparência comunicativa da "palavra cunhada pelo comércio". Imaginar Adorno como um autor que possui uma relação autista com o objeto, na qual o leitor (ou um interlocutor em geral) é completamente abstraído, também seria equivocado. Basta pensar em como na linguagem adorniana, entre um exagero e outro, há uma recuperação tanto da retórica quanto do momento expressivo no discurso filosófico - não é excessivo notar, mais uma vez, que tais recursos estilísticos não corrompem a objetividade da

278 "Parler n'a trait à la réalité des choses que commercialement: en littérature, cela se contente d'y faire une allusion ou de distraire leur qualité qu'incorporera quelque idée." Stéphane Mallarmé, Crise de vers (1897).

279 Consultado em: ARTFL Encyclopédie Project http://artflsrv02.uchicago.edu/cgibin/philologic/getobject.pl?c.2:1615.encyclopedie0416.7135510

${ }^{280}$ Uma linguagem facilitada e comunicativa Habermas viu em Marcuse, que, depois de abandonar o alemão na condição de emigrado, foi forçado a falar e escrever em uma língua menos sofisticada. Enquanto Adorno lamentava o fato de o amigo ter desaprendido a escrever (como se lê em cartas), Habermas via naquela linguagem empobrecida um ganho em comunicabilidades (o que ia na contramão dos mandarins alemães): "You know better than 1 that Herbert Marcuse's spoken English never quite lost the mark of a Berlin accent, that his written English was never completely stripped of the clumsiness of the German grammar underneath. But with his German it was the other way round. By the standards of the jargon of German philosophers Marcuse spoke a straight, affirmative language, easy to understand and without the rhetorical loopholes where the more shocking consequences of a dialectical argument might have found a hiding place. Although rather a shy person, Marcuse was never afraid of being outspoken and for taking the responsibility for what he said, even for taking the risk of oversimplification, if there seemed to be no other way to address an important issue." Habermas, "Psychic Termidor and the Rebirth of Rebellious Subjectivity", p. 69.

${ }^{281}$ Seria certamente equivocado inserir Adorno na tradição filosófico-literária francesa, de Blanchot a Derrida, que canonizou Mallarmé e que se voltou contra qualquer função representativa e comunicativa da filosofia, da ciência e da arte em uma afirmação do "Absoluto Literário". Longe de autonomizar completamente a linguagem e transformar sua relação com a realidade em algo meramente alusivo, a não-comunicabilidade em Adorno não é comemorada, mas é uma exigência objetiva da crítica do mundo falso. 
verdade, tampouco são um adendo a ela, mas são intrínsecos a ela, do mesmo modo como a própria separação entre tese e argumentação é anulada ${ }^{282}$. Entediar o leitor com tautologias e argumentação exaustiva enfraquece o teor verídico daquilo que é expresso $^{283}$. Se o elemento retórico havia sido abolido na filosofia moderna, degradado a "um meio para a produção de um efeito", ou seja, "algo a serviço da mentira", para Adorno "a retórica defende na filosofia aquilo que não pode ser pensado senão na linguagem" ${ }^{284}$. Na irredutibilidade material da linguagem que não pode ser abstraída enquanto signo há uma marca subjetiva que carrega a experiência concreta do sofrimento:

A necessidade de dar voz ao sofrimento é condição de toda verdade. Pois sofrimento é objetividade que pesa sobre o sujeito; aquilo que ele experimenta como seu elemento mais subjetivo, sua expressão, é objetivamente mediado.// Isso pode explicar por que para a filosofia a sua apresentação não é algo indiferente e extrínseco, mas imanente à sua ideia. [...] Para ela, expressão $e$ acuro lógico não são possibilidades dicotômicas. Eles necessitam um do outro, nenhum dos dois é sem o outro. [...] O pensamento só se torna conclusivo enquanto algo expresso, somente por meio da apresentação linguística; o que é dito de modo frouxo é mal pensado. ${ }^{285}$

Além desse vínculo incontornável entre pensamento e linguagem apontado por Adorno, pode-se dizer ao mesmo tempo que há uma vantagem cognitiva de partir do sofrimento para a compreensão do mundo (em ambos casos visando o fim do sofrimento) que dá à expressã $o^{286}$ um teor verídico, ao ponto de Adorno, algumas décadas depois, relativizar um de seus exageros e dar razão de ser para a lírica contemporânea (retomando o tema expressionista do grito): "O sofrimento perenizante tem tanto direito à expressão

\footnotetext{
${ }^{282}$ Como o próprio Adorno diz em relação à dialética.

283 "Textos que se põem timidamente a seguir inteiro cada passo, inelutavelmente acabam caindo no banal e num tédio que não só se refere à tensão na leitura como à sua própria substância. [...] O conhecimento se dá, na realidade, num feixe de preconceitos, intuições, inervações, autocorreções, antecipações e exageros [...].” MM, p. 76.

${ }^{284} \mathrm{DN}$, p. 55.

${ }^{285}$ [grifos meus] DN, p. 24.

${ }^{286}$ Também em Günther Anders há um momento expressivo no exagero na medida em que "a pungência é filha da dor": "Se minhas palavras soarão mais pungentes e indignadas que as que habitualmente são ouvidas aqui, não se surpreendam. Mas creiam-me: a pungência é somente filha da dor. E a indignação somente o eco da vontade decidida de não descansar antes que nós e "nós' significa: aqueles lá e nós aqui - não tenhamos aniquilado o perigo da aniquilação." Anders, "Über Verantwortung heute" in Die atomare Drohung, cit., p. 25.
} 
quanto o martirizado tem de berrar; por isso, é bem provável que tenha sido falso afirmar que depois de Auschwitz não é mais possível escrever nenhum poema."287

Ninguém negaria que, se a verdade for de fato verdadeira, ela deve, pelo menos um pouco, convencer - não é por acaso que Adorno visa também resgatar a retórica, outrora rebaixada a instrumento da mentira: “A retórica defende na filosofia aquilo que não pode ser pensado senão na linguagem. [...] Ela é continuamente corrompida pela meta da persuasão, sem a qual, no entanto, a relação do pensamento com a práxis desapareceria uma vez mais do ato de pensamento." 288 E como o convencimento não ocorre necessariamente pelas estritas regras da justificação (como quer a teoria política habermasiana do discurso), ele atravessa as dimensões cognitiva, moral, afetiva e estética - e isso constitui essa relação ao outro, esse poder da verdade de, como diz Marx, "prender os homens desde que demonstre sua verdade face ao homem."

Tal posição certamente não vai contra a desconfiança frente a todo truque expressivo e linguístico, pois, como lembra Günther Anders nessa pequena anedota, também o sussurro pode enganar:

Pessoalmente mal conheci Heidegger. Uma vez em Marburg esquece-me como isso ocorreu - pernoitei na casa do casal Heidegger. A conversa correu bastante bem, após um jantar em que comemos massa. Então citei, sem inicialmente nomear o autor, o magnífico dito de Voltaire: "Não basta gritar: é importante, também, não ter razão". Embora totalmente destituído de senso de humor, ele se divertiu. Quando, porém, expliquei que o dito era de Voltaire, primeiro ela - após o quê, também ele - ficou de cara amarrada. Mas a noite só se estragou completamente quando eu continuei, no tom mais inocente do mundo, dizendo que, naturalmente, era válido também o dito simétrico: "Não basta murmurar: é importante, também, ter razão". Enquanto ela, naturalmente, não entendeu nada, ele por um momento me lançou um olhar cheio de ódio. Sentiu-se posto a nu. Pois era sua tática diária forçar, através de um murmúrio quase inaudível, um silêncio total na sala, para convencer os ouvintes de que tudo o que eles tinham conseguido ao menos

\footnotetext{
${ }^{287} \mathrm{DN}$, p. 300. O grito, que é ao mesmo tempo expressão de sofrimento e força de revolta, aparece no Laocoonte de Lessing: "O grito é a expressão natural da dor corporal. Os guerreiros de Homero não raro caem no chão aos gritos. A Vênus arranhada grita alto; não para a expor com esse grito como a deusa branda da volúpia, mas antes para fazer justiça à natureza sofredora. Pois mesmo o brônzeo Marte, quando ele sentiu a lança de Diomedes, gritou de modo tão horrível, como se dez mil guerreiros enfurecidos gritassem ao mesmo tempo, de modo que os dois exércitos se espantaram." Lessing, Laocoonte. Tal motivo, vinculado à grande recusa, é retomado também por John Holloway e é o ponto de partida que estrutura seu ensaio-manifesto Change the world without taking the power.

${ }^{288}$ [grifo meu] DN, p. 55.
} 
acusticamente capturar tinha sido "desvelado", logo, verdadeiro; não: tinha sido $a$ verdade. ${ }^{289}$

\section{“O todo é o não-verdadeiro"}

Até agora insisti na dimensão ético-prática do conceito de verdade não só de Adorno, mas presente em diversos autores da teoria crítica, como porta de entrada para a discussão moral propriamente dita (que, como seria de se pressupor, não se constitui como uma disciplina filosófica autônoma - o vínculo com o conceito de verdade prova a dependência de tal discussão de uma compreensão histórica da realidade por meio de uma experiência afetiva e cognitiva com os acontecimentos inaceitáveis e repugnantes do mundo, sendo a filosofia moral antes uma reação à ocasião - pensemos em Hiroshima para Anders e Auschwitz para Adorno ${ }^{290}$ ). Entretanto, tal conceito de verdade possui diversas facetas que nos remetem à dialética hegeliana, que abordaremos aqui na medida em que ela ilumina nosso objeto.

Talvez possa parecer que o conceito de verdade apresentado até agora, cujo vínculo com a utopia (sem imagens) está em uma relação antitética com a empiria, seja essencialmente idealista no pior dos sentidos, algo que beire um platonismo reciclado: verdadeiras são as ideias e falsos os objetos empíricos. Entretanto, é preciso reiterar que, da perspectiva da teoria crítica, não há "a verdade" que paira acima das coisas, ou seja, que tais ideias, no sentido platônico, inexistem. Mas podemos resumir que a motivação central desses autores, nas reflexões sobre o conceito de verdade, é sobretudo um impulso crítico contra o positivismo em sua fixação aos fatos isolados. A falsidade do dado singular, pensado a partir da dialética, se dá em três âmbitos: 1) na objetividade que anula o momento subjetivo, 2) na anulação do caráter processual da realidade, em suma, do tempo (histórico), 3) na anulação da dimensão constitutiva das relações, isto é, da totalidade (social) e suas mediações.

Na discussão de Adorno sobre o positivismo na sociologia alemã, o conhecimento que vai para além do dado singular e que não repete a realidade de forma tautológica é também necessariamente uma Übertreibung, um ir além daquilo que está meramente aí, sem o qual não há conhecimento efetivo:

\footnotetext{
${ }^{289}$ Günther Anders, "Heidegger-Erinnerung (Wien 1984)” in: Über Heidegger, p.11. (A tradução deste trecho é de Antonio Cicero).

${ }^{290}$ Retomaremos esse assunto no capítulo 3.
} 
Sem ruptura, sem impropriedade, não existe conhecimento que seja mais do que repetição ordenadora. Que essa repetição ordenadora ao mesmo tempo não sacrifique com isso a ideia de verdade, tal como seria muito mais de acordo com o positivismo em seus representantes mais consequentes, circunscreve uma contradição essencial: o conhecimento, e isso de maneira alguma ocorre per accidens, constitui um exagero. Pois tampouco como algo singular é 'verdadeiro', mas, graças à sua mediação, também forma seu próprio outro, assim também tampouco o todo é verdadeiro. Que ele permaneça inconciliado com o singular é expressão de sua própria negatividade. A verdade é a articulação desta relação. ${ }^{291}$

A relação entre verdade e totalidade em Adorno é uma via de mão dupla ao mesmo tempo em que ela é a pedra de toque para a compreensão do conceito de sociedade, ${ }^{292}$ de modo que a subordinação dos fatos singulares à totalidade é um processo social real, ou seja, tais categorias (como totalidade e identidade) não devem ser vistas como algo "do sistema filosófico", e que bastaria mudar a filosofia para se livrar dessa coerção que violenta o particular e a diferença. ${ }^{293}$ A totalidade em Adorno é um conceito descritivo e se refere à objetividade social. Não custa lembrar que a "totalidade não constitui uma categoria afirmativa, mas sim crítica." ${ }^{294}$ Isto é, não há um conceito positivo e hipostasiável de totalidade, tampouco há uma totalidade verdadeira (portanto, justa) por vir - este o momento anti-hegeliano (e anti-lukacsiano) de Adorno: "Uma humanidade liberada não persiste como totalidade. ${ }^{295}$ Quando Adorno inverte a afirmação de Hegel

${ }^{291}$ Adorno, "Controvérsia..." p. 241. (tradução modificada)

${ }^{292}$ Importante notar que também tal conceito de sociedade como totalidade é abandonado em Habermas em prol de um conceito dual de sociedade, onde "mundo da vida" (esfera privada e espera pública) e "sistema" (sistema poder e sistema dinheiro) aparecem como regimes separados de normatividade, condenados a uma eterna queda de braço (o "sistema" não deve ser abolido, algo que se tornou inviável em uma sociedade complexa, de modo que cabe proteger o mundo da vida da "colonização" normativa do sistema, isto é, deve-se garantir que a racionalidade instrumental fique onde ela está e não invada as outras esferas sociais. A partir disso, trabalha-se com um conceito próprio de patologia social que é precisamente uma afetação da autonomia das dimensões com regimes próprios de validade e normatividade. Se o mundo capitalista for visto como totalidade, tal patologia só pode ser vista como constitutiva, pois apesar da autonomização das esferas, a autonomia é aparência.

${ }^{293}$ Como lembra Fredric Jameson: "Thought's categories are collective and social; identity is not an option but a doom; reason and its categories are at one with the rise of civilization and capitalism, and can scarcely be transformed until the later is transformed." Fredric Jameson, Late Marxism: Adorno, or the persistence of the dialectic

294 "Controvérsia...", p. 223 rever tradução

${ }^{295}$ Idem. Ou seja, a totalidade, tal como a dialética, não é eterna. Não se deve hipostasiar nenhuma categoria dialética, como totalidade ou contradição, tampouco a própria dialética, visando tornála uma forma de conhecimento e ação verdadeira e transhistórica, pois, como o próprio Adorno afirma, "a dialética hipostasiada torna-se antidialética". "Controvérsia..." p. 234. Hipostasiar a dialética seria tão falso como hipostasiar a contradição: a idolatria da contradição não se confunde 
da Fenomenologia do Espírito, segundo a qual "o verdadeiro é o todo", e afirma na Minima Moralia que "o todo é o não-verdadeiro", uma série de mal-entendidos foi produzida justamente pelo que há de contra-intuitivo no conceito adorniano de verdade (que é, por sua vez, bastante próximo de Hegel). Daí deduziu-se que a totalidade seria algo simplesmente irreal, uma ilusão intelectual que não existe, e que a verdade estaria nas particularidades. Nada mais equivocado. Com isso expressa-se antes que o todo é o estado efetivo da não-liberdade, ou seja, o mundo tal como ele é, a injustiça real no mundo transformado em sistema, um estado portanto a ser negado, pois ele não deve ser como ele é. "A totalidade, numa formulação provocativa, é a sociedade como coisa em si, provida de toda carga de coisificação."296

Ora, o mundo enquanto totalidade não é outra coisa senão a sociedade moderna universalmente mediada pelo trabalho abstrato (e é somente por meio da mediação que a totalidade se exprime e se torna reconhecível no particular). A formulação do conceito enfático de sociedade, tal como pensado por Adorno, deriva da universalização produzida pelo valor e pelo trabalho como nexo social, tal como aparece n'O Capital de Marx. ${ }^{297}$ A totalidade, portanto, é tão social como abstrata (e não por isso menos real ou "concreta"298): basta notarmos como Marx opera uma homologia entre o conceito de

com dialética, pois ela, pelo contrário, como observa Marx, forma o cerne da ideologia burguesa: "O pequeno-burguês deifica a contradição, pois a contradição é o núcleo da sua essência. Ele é a própria contradição social em ação." (Carta a Anenkow) apud Paulo Arantes, Ressentimento da dialética. São Paulo: Paz e Terra, 1996, p. 30. Adorno diz a mesma coisa: "O conceito de contradição deve ser tão pouco hipostasiado como qualquer outro conceito." EiD, p. 86. Em seu texto sobre Kierkegaard, a hipostasia da contradição aparece como culto burguês do paradoxo: "A contradição fica sem solução. Kierkegaard tratou de safar-se paralisando-a e hipostasiando-a sob o nome de 'paradoxo'. [...] [a] filosofia de Hegel, em seu avanço, tentava desatar o nó da contradição, em Kierkegaard, a contradição mesma se converte, à força, na solução.” Theodor Adorno, "Kierkegaard outra vez" in Kierkegaard: construção do estético, p. 254.

${ }^{296}$ Controvérsia, p. 223

${ }^{297}$ Como bem percebeu Hans-Georg Backhaus: "O conceito enfático de sociedade [na Escola de Frankfurt] é pensado tanto a partir da teoria marxiana do valor como do conceito objetivo de ideologia. [...] Trabalho social é, para a Escola de Frankfurt, totalidade social." Dialektik der Wertform: Untersuchungen zur Marxschen Ökonomiekritik, p. 75.

${ }^{298}$ Lembremos que, na dialética, abstrato é não o todo, mas o singular isolado, removido do nexo que o mobiliza e produz. Explicando Hegel em sala de aula, Adorno diz: "O abstrato [das Abstrakte] em Hegel também não significa exatamente a mesma coisa que o conceito 'abstrato' [Abstraktheit] no pensamento corrente. Abstrato em Hegel é, a saber, não simplesmente o isolado, a determinação individual na medida em que ela é retirada, em sentido literal 'abstraída', do todo ao qual ela pertence. E o movimento do pensamento enquanto um movimento em direção ao todo é, no sentido de Hegel, o movimento em direção ao 'concreto', a saber, ao 'Zusammengewachsene', tal como é de fato uma das determinações da verdade em Hegel, que a verdade é o concreto. Isso significa que o abstrato é realmente o individual, o ainda isolado, e o começo é por isso falso, porque ele é abstrato, isolado, porque ele ainda não passou ao todo [...]." EiD, p. 57. 
"abstrato" e o de "social": tudo aquilo que é "abstrato", "metafísico", "sobrenatural", "fantasmagórico" refere-se precisamente a tudo aquilo que é social (com a magia real do fetichismo da mercadoria na base daquilo que constitui as relações no capitalismo), em sentido eminentemente dialético - não por outro motivo o positivismo manteve-se distante dessa fantasmagoria sobrenatural tão difícil de apreender chamada sociedade. Se a totalidade é essencialmente totalidade social, também o que é social é, inversamente, "total" no sentido de que é mediado pelo todo. É na análise marxiana ${ }^{299}$ da forma valor que Adorno encontra quilo que produz a sociedade:

O que realmente torna uma sociedade em algo social, através do que, em sentido estrito, ela tanto é constituída como conceito, quanto como realidade, é a relação de troca, que unifica virtualmente todos os homens participantes desse conceito de sociedade. [...] Essa abstração [do valor] é propriamente a forma específica do processo de troca ele mesmo, da situação social fundamental que torna possível a própria geração de algo como a socialização. ${ }^{300}$

Também no ensaio Aspectos, aparece esse conceito de sociedade como uma interpretação materialista dos conceitos de espírito e de essência em Hegel: "A sociedade manifesta-se nos fenômenos da mesma forma que, em Hegel, a essência neles se manifesta. A sociedade é um conceito tão essencial quanto o de Espírito. [...] O princípio da equivalência do trabalho social conduz à sociedade, no sentido burguês moderno, ao

\footnotetext{
${ }^{299}$ Se o conceito marxiano de "social" é essencialmente uma teoria da dominação impessoal, há ainda um outro conceito de "o social" pensado por certa sociologia foucaultiana (na esteira de Durkheim) como uma tecnologia de gestão governamental que surge no contexto de arrefecimento das paixões políticas (como formulado por Donzelot). Interessante seria justamente pensar o vínculo entre as duas dimensões, sem cair no árido debate da pura "crítica categorial" e também sem perder de vista tais mediações conceituais inerentes ao conceito marxiano de capital. ${ }^{300}$ Adorno, Introdução à Sociologia, p. 106. Também na Introdução à controvérsia... aparece a mesma ideia de que o que produz totalidade é o trabalho abstrato que se efetiva na troca de mercadorias: "À objeção de que por trás do conceito de totalidade nada mais existe do que a trivialidade de que tudo se relaciona com tudo, há que replicar que a má abstração desta proposição não constitui apenas um produto débil do pensamento, mas o teor básico da sociedade: o da troca. Na sua realização universal, e não apenas na explicação científica do mesmo, é que se abstrai objetivamente; prescinde-se da constituição qualitativa dos produtores e dos consumidores, do modo de produção, e até da necessidade, que é satisfeita secundariamente pelo mecanismo social. A humanidade convertida em clientela, sujeito das necessidades, é ainda, para além de todas as representações ingênuas, preformada socialmente não apenas pela situação técnica das forças produtivas, mas igualmente pelas relações econômicas em que elas funcionam. $\mathrm{O}$ caráter abstrato do valor de troca está vinculado a priori à denominação do universal sobre o particular, da sociedade sobre seus membros coatos. [...] A conexão total configura-se concretamente na medida em que todos são obrigados a se submeter à lei abstrata da troca, sob pena de sucumbirem, independente de serem ou não subjetivamente conduzidos por um 'afã de lucro'." Adorno, Introdução à controvérsia..., p. 224.
} 
abstrato e ao mesmo tempo ao que há de mais real, exatamente como Hegel ensina com o conceito enfático de conceito.,

\section{Cerne temporal da verdade}

É de se imaginar, mas não é exatamente uma obviedade, que, no pensamento dialético, o vínculo da verdade com aquilo que ainda não é, em sua relação negativa com aquilo que é, tende a vincular-se a uma filosofia da história: trata-se de um pensamento que, para o bem e para o mal, é herança da temporalização moderna da utopia e da história. Essa temporalização da utopia tem data (século XVIII) e surge no momento em que, segundo Koselleck,

as possibilidades espaciais de situar as utopias na finitude da superfície da nossa Terra haviam se esgotado. Os espaços utópicos haviam sido ultrapassados pela experiência. A melhor solução para escapar dessa pressão experiencial acumulada era simples, mas precisava ser encontrada. Se a utopia já não podia mais ser estabelecida nem na nossa Terra presente nem no além, era preciso recuar para o futuro. Finalmente haviam encontrado o espaço de desafogo para o qual a imaginação, infinitamente reproduzível como o tempo, podia fluir livremente. ${ }^{302}$

Escatologia secularizada que aparece com a experiência moderna do progresso e que se torna fundamento da filosofia burguesa da história: "trata-se de um antiapocalipse ${ }^{, 303}$. E quando pensamos em Hegel e Marx, e ainda no jovem Lukacs e em Bloch, estamos ainda no barco das grandes promessas da modernidade, com um horizonte nada menos que revolucionário.

Se a configuração dessa utopia temporalizada era "deduzir do presente ruim um futuro melhor" ${ }^{304}$, fazer tal dedução depois do Campo e da Bomba seria no mínimo obsceno. Ser honesto com essa experiência histórica e ao mesmo tempo manter-se fiel ao ideal revolucionário moderno, ao desejo pelo "totalmente outro [das ganz Andere]" e pela reconciliação ainda não existente, é talvez o que forma o nó das reflexões sobre a história de Adorno: ser crítico da modernidade capitalista e manter-se modernista incorrigível, ${ }^{305}$ sem abrir mão daquilo que foi prometido, mas jamais realizado, que é, come se sabe, o

\footnotetext{
${ }^{301}$ Adorno, Três estudos sobre Hegel, p. 93.

${ }^{302}$ Reinhart Koselleck, "A temporalização da utopia" in: Estratos do tempo: estudos sobre história, p. 124.

${ }^{303}$ Ibid.

${ }^{304} \mathrm{Ibid}, \mathrm{p} .136$.

${ }^{305}$ Certamente não no sentido de permanecer fiel a um melhoramento progressivo como dá a entender a expressão "modernidade inacabada", tal como Habermas imputa a Adorno.
} 
núcleo duro da ideia de crítica imanente - contrapor a sociedade burguesa a suas próprias normas (sem tomar tais normas como um positivo, mas tomando essa contradição como ponto de partida). Günther Anders não estaria tão distante, mas ao enxergar obsolescências por toda parte, é difícil pensar que tais promessas sejam ainda em alguma medida realizáveis ${ }^{306}$ - o que dificultaria a própria ideia de crítica imanente. ${ }^{307}$ A espera pelo que não chegará e continuar esperando é, como em Beckett, não um niilismo, mas sinal da incapacidade de tornar-se niilista. ${ }^{308}$ Há uma mudança do regime temporal na

${ }^{306}$ Há uma passagem do "Noch nicht [ainda não]" para o "Gerade-noch", que significa algo como "quase", "por pouco", "por um triz", "por um fio" (como por exemplo na expressão "escapou por pouco"). Anders conta que encontrou talhado em uma mesa de uma universidade alemã os seguintes versos (que brincam com o primeiro nome de Bloch, "Ernst" [sério] e o sobrenome de Günther, "Anders" [outro]): PRINZIP VERZWEIFLUNG ODER EINMAL ETWAS ANDERS // ernst bloch spricht: / "wir sind noch nicht." / ernster als bloch / wäre: "gerad' noch." / anders wär: / "nicht mehr." Günther Anders, Die Antiquiertheit des Menschen II, p. 417. De todo modo, não há como deixar de ver no desespero andersiano, que anuncia o fim do mundo, a esperança de que o mundo não acabe (embora o homem, que é "antiquado/obsoleto", seja também já um homem "sem mundo", como é dito em outro título seu). Mas há um desejo de ver realizado aquilo que é obsoleto ("humanidade" e "mundo").

${ }^{307}$ Adorno vive tal contradição na medida em que ele permanece crítico imanente ao mesmo tempo em que anuncia a impossibilidade de se continuar fazer crítica imanente, como no aforismo O erro de Juvenal da Minima Moralia. A dissociação entre norma e fato é anulada, e o fato tornase a própria ideologia, boicotando o efeito crítico da ironia: "O meio da ironia, a diferença entre ideologia e realidade, desapareceu, resignada à confirmação da realidade na sua meta duplicação. A ironia exprimia: assim a coisa pretende ser e assim ela é de fato; hoje, contudo, o mundo proclama mesmo na mentira radical que é assim mesmo, e essa simples descoberta lhe parece coincidir com o bom. Na rocha do existente nenhuma fenda dá apoio à mão do irônico.” $\mathrm{MM}, \mathrm{p}$. 208. Moishe Postone aponta um problema na ideia de crítica imanente (a meu ver, mal compreendida) e faz uma estranha distinção entre "crítica negativa" e "crítica positiva". Segundo sua formulação, a crítica negativa não possui nenhuma norma à qual a realidade é comparada (de forma que ela ganha em radicalidade, como na crítica do valor de Marx), enquanto a crítica positiva quer reformar a realidade visando seus próprios critérios, como um engenheiro que critica o mau funcionamento de uma máquina visando seu bom funcionamento (tal como o marxismo tradicional em seu "ponto de vista do trabalho" na crítica do capital, o que impossibilita uma metacrítica do capital enquanto crítica do trabalho). Moishe Postone, Time, Labor, and Social Domination, 1993, pp. 63-64. Para uma discussão sobre a crítica imanente em Adorno partindo da problemática posta por Postone, ver Amaro Fleck, Da crítica imanente à crítica do sofrimento: a justificação normativa na obra tardia de Adorno, in: ethic@- Florianópolis, v.15, n.1, p.65-84, Jul. 2016. No entanto, creio que essa crítica imanente de engenheiro, claramente positiva, não pode ser identificada à ideia de crítica imanente tal como ela é entendida na dialética, uma vez que, na contraposição do objeto ao seu conceito, que resulta em negação determinada, nem o conceito nem o objeto permanecem inalterados. Por isso o conceito dialético de conceito não deve ser confundido com a ideia regulativa kantiana, que permanece como norma verdadeira e eterna. 308 “[...] uma vez que eles por fím não perdem a esperança nem são capazes de perdê-la, eles são ideólogos ingênuos e desesperadamente otimistas. O que Beckett apresenta não é portanto o niilismo, mas a incapacidade do homem de, mesmo em uma situação insuperavelmente [unüberbietbar] sem esperança, ser niilista. Uma parte da tristeza miserável que a peça irradia surge não tanto da situação sem perspectiva dos dois heróis, mas justamente do fato de que eles, por continuarem esperando, não estão à altura dessa situação, ou seja, não são niilistas. E a essa 
espera destituída de conteúdo: "o antes e o depois tornam-se como direita e esquerda, ou seja, temporalmente neutros"309 - o tempo vai para o espaço, em suma. ${ }^{310}$ Certamente essa mudança radical na experiência da temporalidade histórica afeta o "cerne temporal da verdade", tal como aparece nas constantes lutas teóricas de Adorno contra as eternizações. Pois o que se começou a viver, ao menos segundo Beckett, é um tempo "que parece parar e torna-se, se for permitido imitar a expressão hegeliana 'má infinitude', uma 'má eternidade'.,’311

Mas para além do diagnóstico do tempo (ou do fim dele) próprio da perenização do capitalismo do pós-guerra (abordado no capítulo anterior), mantenho-me aqui ainda na discussão conceitual: já na dialética hegeliana, a concepção de verdade estava radicalmente vinculada à ideia de movimento. Na Ciência da lógica, a verdade é "o devir" [das Werden], ela não é nem o ser nem o nada, mas o movimento do ser no nada e do nada no ser. ${ }^{312} \mathrm{Na}$ Fenomenologia do espirito, há um tempo da verdade, que é a própria verdade na história, ou dito de outro forma, a verdade se manifesta de forma temporal: “O verdadeiro tem a natureza de eclodir quando chega o seu tempo, e só quando esse tempo chega se manifesta; por isso nunca se revela cedo demais nem encontra um público despreparado. ${ }^{, 313}$ No entanto, a dialética não pode ser confundida com uma ontologia do

incapacidade eles devem a força de sua comicidade." Günther Anders, Die Antiquiertheit des Menschen I, p. 221.

${ }^{309}$ Idem, p. 221.

${ }^{310}$ Salvo engano, esse é o assunto de Paulo Arantes por excelência. Em Hegel: a ordem do tempo, o assunto era a temporalização do espaço: "Dizer, ao contrário, que o tempo é a verdade do espaço, como o exige Hegel, significa que o espaço, em virtude da reflexão própria a seu conceito, se torna tempo." Hegel: a ordem do tempo, p. 29. A teorização sobre a Era da Emergência em $O$ novo tempo do mundo diagnostica o fim do processo pensado por Hegel (nada menos que a Era Moderna), seu resultado é o "tempo intemporal da urgência perpétua" ( $O$ novo tempo do mundo, p. 94), anulação do passado e do futuro no Presente e tem como efeito o seu contrário, isto é, a espacialização do tempo, pois "é a própria noção moderna de Progresso - e a temporalização da história que a tornou pensável - que literalmente vai para o espaço" (Ibid, p. 62). Sobre a espacialização do tempo na filosofia da música de Adorno, ver Eduardo Socha, Tempo Musical em Theodor W. Adorno. Tese de Doutorado, USP, 2015.

${ }^{311}$ Günther Anders, Antiquiertheit des Menschens I, p. 223.

312 "O que é a verdade, não é nem o ser nem o nada, mas que o ser não passa, mas passou para o nada e o nada não passa, mas passou para o ser. Da mesma maneira, porém, a verdade não é sua indistinção, e sim que eles não são o mesmo, que são absolutamente distintos, mas igualmente inseparados e inseparáveis e imediatamente cada um desaparece em seu contrário. Sua verdade é, portanto, esse movimento do desaparecer imediato de um no outro: o devir; um movimento onde ambos são distintos, mas por meio de uma diferença que igualmente se dissolveu imediatamente." Hegel, Ciência da Lógica.

${ }^{313}$ Hegel, Fenomenologia do espírito, p. 70. 
tempo ou do movimento, isto é, não se trata de uma historicidade abstrata da verdade. ${ }^{314}$ A elevação do tempo a princípio fundador de todo ser é recaída na estaticidade da metafísica: isso era o núcleo argumentativo de um dos primeiros textos de Horkheimer publicados na revista do Instituto de Pesquisa Social, que foi dedicado à crítica da concepção bergsoniana de tempo. Bergson "nega o tempo na medida em que o eleva a princípio metafísico." ${ }^{315}$ A crítica da filosofia contemporânea, presente ainda nas críticas a Husserl e Heidegger na Dialética Negativa, era desde o começo denunciar o quão abstrato (e falso) era o movimento "vers le concret" $" 116$ e a ideia da "temporalidade concreta" (Bergson).

De todo modo, é importante ressaltar que a formulação em torno de um "cerne temporal [Zeitkern] da verdade", que esteve sobretudo presente nos textos de Adorno, não era consenso: não foram poucas as vezes em que Horkheimer hesitou quanto a essa temporalização da verdade. Para ele, vincular a verdade ao tempo implicava uma relativização. No registro de uma conversa de outubro de 1939 (pouco mais de um mês após a invasão alemã da Polônia), Horkheimer questionava Adorno: "Nós precisamos nos decidir: ou o historicismo tem razão que só há verdade para um determinado tempo, ou a verdade deve permanecer ligada a algo eterno que não entra em declínio."317 Ao mesmo tempo em que Horkheimer afirmava que "a verdade e o bem [das Gute] são efêmeros"318, no fragmento Espírito e tempo ele escreve o contrário: "Em toda frase que quer ser verdadeira - ou seja, em toda frase - abstrai-se o tempo. Pois uma frase cuja verdade é estimulada pelo tempo é justamente não verdadeira." ${ }^{319}$ Horkheimer vai mais longe e chega ao ponto de escrever um fragmento intitulado A-historicidade da verdade [Ungeschichtlichkeit der Wahrheit], em que afirma: "O pensamento de que a verdade seja histórica significa basicamente resignação ante o positivismo. Precisamente aquilo que não é meramente histórico chama-se verdade." ${ }^{320}$ Mais adiante, já bastante distante de

\footnotetext{
314 “A dialética não significa, e não pode significar, uma segurança abstrata, como uma visão de mundo, digamos da historicidade do ser ou da historicidade da verdade; mas se lhe cabe efetivamente conhecer o conceito filosófico da coisa, então isso significa que ela deve abrir concretamente os significados históricos dos objetos com os quais ela tem a ver." EiD, p. 24.

${ }^{315}$ Horkheimer, Zu Bergsons Metaphysik der Zeit.

${ }^{316}$ Também Günther Anders lançou os pressupostos para a Dialética Negativa, no que se refere à crítica da ontologização do ôntico, em seu texto sobre a pseudo-concretude em Heidegger. Günther Anders, "Die Schein-Konkretheit von Heideggersphilosophie" in: Über Heidegger.

${ }^{317}$ HGS 12, p. 506.

${ }^{318}$ HGS 14, p. 346.

${ }^{319}$ HGS 6, p. 195.

${ }^{320}$ HGS 14, p. 125
} 
pretensões dialéticas, a atemporalidade da verdade aparece em sua relação com Deus, um incondicionado eterno: “A afirmação de que não há nenhuma verdade eterna, nada divino, ou não é verdadeira, pois não há verdade, ou afirma o que ela pretende negar. Ela precisa silenciar." 321

Tal relação entre verdade e tempo é completamente diversa em Adorno. Para ele, "a verdade é resultado" 322 , tal como diz Hegel na Fenomenologia do Espírito. Esse caráter processual e histórico da verdade será para Adorno antídoto contra tudo que é eterno e ontológico: "A dialética não afirma que a verdade seja o que permanece igual a si [das sich selbst Gleichbleibende], o eterno, mas ela possui um conceito de verdade que tem em si mesmo a determinação da história." ${ }^{, 323}$ A diferença entre puro ser e mera existência histórica é anulada. ${ }^{324}$ Isso não implica, no entanto, como acusa Horkheimer, uma renúncia relativista, o que Adorno explicitava já em seu estudo sobre Husserl: "Não se trata, como quer o relativismo, da verdade na história, mas sim da história na verdade., 325 Ou seja, não se trata da afirmação banal de que tudo é efêmero, mas de dizer que o tempo é inerente à verdade. ${ }^{326}$ Isso ficaria mais claro se fôssemos diretamente para as análises de Adorno e Benjamin sobre os objetos empíricos, sejam eles estéticos ou não, e observássemos como a "verdade não-intencional"327 aparece em sua dimensão temporal nos próprios objetos, mas fazer tal movimento seria uma injustiça a tais objetos ao reduzilos a meros exemplos do que estamos discutindo. Mas evitemos aqui a discussão em torno do materialismo micrológico de Benjamin (e sua retomada adorniana), pois pretendo antes enfatizar como essa relação entre verdade e tempo se vincula à dimensão "prática". E é isso que está em jogo no curso Introdução à dialética, quando Adorno diz:

Isso é, por assim dizer, a virada prática ou política da ideia de cerne temporal da verdade: não há uma verdade universal, que

\footnotetext{
${ }^{321}$ Idem, p. 126.

${ }^{322}$ Hegel, Fenomenologia do Espírito.

${ }^{323}$ EiD, p. 26

${ }^{324}$ Idem.

${ }^{325}$ A referênicia aqui é Walter Benjamin, que Adorno cita logo após essa frase, e que cunha o termo Zeitkern: "O abandono decisivo do conceito da 'verdade atemporal' está em jogo. Todavia, a verdade não é - como o marxismo o afirma - uma função temporal do conhecer, mas está ligada a um cerne temporal, que se encontra ao mesmo tempo no conhecido e naquele que conhece." W. Benjamin, Paris, die Hauptstadt des XIX. Jahrhunderts [Passagenarbeit] apud Adorno, Para a metacritica da teoria do conhecimento, p. 228.

${ }^{326}$ EiD, p. 27

${ }^{327}$ A ideia de "verdade não-intencional" aparece no prefácio de Benjamin a seu estudo $A$ origem do drama barroco alemão e é retomada por Adorno desde seu Para a metacrítica... até a Dialética Negativa.
} 
permanece estática em si [eine allgemeine, statisch in sich ruhende Wahrheit], nem uma sobre a sociedade, mas em realidade a verdade advém sempre somente da situação concreta, e no instante em que ela se separa [ablöst] da situação concreta ou crê elevar-se sobre ela, ela é condenada assim à fraqueza [Kraftlosigkeit $]$ e à impotência [...]. ${ }^{328}$

Não há como deixar de pensar que na ideia de cerne temporal da verdade há também uma latência do novo na verdade, e aqui retorna aquilo com o que iniciamos esse capítulo: a utopia concreta na verdade. Lembremos que não foram poucos os autores que exaltaram a potência criadora do diverso no tempo, de Bergson a Thomas Mann. ${ }^{329}$ Mas o que Adorno afirma ainda na mesma aula do dia 22 de maio de 1958 não é trivial e dá ao "cerne temporal da verdade" um estatuto central para o que quer que pensemos sobre filosofia moral e política: a unidade entre teoria e práxis em todo pensamento dialético, "de Fichte a Marx", é "consequência do cerne temporal da verdade", pois isso significa que "a verdade mesma não é nada que permanece contemplativo frente ao tempo [nichts der Zeit kontemplativ Gegenüberstehendes], na medida que ela tem sua forma temporal [zeitliche Gestalt] e sempre possui também simultaneamente uma relação bastante drástica com a práxis possível." 330

\section{Contradição verdadeira: o conceito hegeliano de verdade}

As coisas finitas são [...] mas a verdade desse ser é o seu fim.

Hegel, Ciência da Lógica

A esta altura já deve estar claro o quão atrelado a Hegel é o conceito de verdade dos frankfurtianos. Isso se torna mais evidente nos textos de alguns desses autores dedicados a interpretar diretamente a obra hegeliana, como por exemplo nos Três estudos sobre Hegel de Adorno (que retoma o que ele já vinha desenvolvendo nos cursos

\footnotetext{
${ }^{328}$ EiD, p. 55.

${ }^{329}$ Lembro aqui, por exemplo, de seu ensaio Louvor à transitoriedade, onde ele diz que a transitoriedade é "a alma do ser, é aquilo que proporciona a toda vida, valor, dignidade e interesse, pois ela cria o tempo - e tempo é, pelo menos potencialmente, a dádiva mais alta e a mais útil, aparentada em sua essência com, idêntica mesmo a todo criativo e ativo, a toda vivacidade, a todo querer e aspiração, a todo aperfeiçoamento, a todo progresso para o mais sublime e o melhor. Onde não há transitoriedade, princípio e fim, nascimento e morte, não há tempo, - e a falta de tempo é o nada estagnado, tão bom e tão ruim como o desinteressante absoluto." Thomas Mann, "Louvor à transitoriedade" in: Ensaios.

${ }^{330}$ EiD.
} 
Introdução à dialética e Questões da dialética), mas também nos remete de volta a um texto tão antigo como a tese de habilitação de Marcuse, Hegels Ontologie und die Theorie der Geschichtlichkeit [A ontologia de Hegel e a teoria da historicidade], publicada em 1932, e também o livro Reason and Revolution: Hegel and the Rise of Social Theory, igualmente de Marcuse e publicado em 1941. Aquilo que Habermas criticara enquanto herança hegeliana torna-se aqui bastante claro, especialmente em relação à diferença entre verdade e correção (enquanto adequação entre o pensamento ou uma proposição e um estado de coisas). Na sua tese de 1932, diz Marcuse que "é uma das convicções fundamentais de Hegel que a verdade é um caráter do ser e não, por exemplo, do conhecimento." 331 Marcuse encontra mesmo em cartas de Hegel referências a essa concepção de verdade: "um objeto não verdadeiro pode muito bem existir, e nós podemos ter uma representação [Vorstellung] correta desse objeto; mas um tal objeto não é como ele deve ser, isso é, ele não conforme a seu conceito [seinem Begriff nicht gemäß]. ${ }^{, 332}$ Essa ideia hegeliana da verdade como um atributo não das representações (que seriam adequadas ou não à realidade), mas da própria realidade, Marcuse retoma posteriormente em seu outro livro sobre Hegel: "Truth is not only attached to propositions and judgements, it is, in short, not only an attribute of thought, but of reality in process. Something is true if it is what it can be, fulfilling all its objective possibilities. In Hegel's language, it is then identical with its "notion' [Begriff]." 333 Ou seja, quando os frankfurtianos dizem, por exemplo, que o mundo (ou a vida) é falso, e não somente injusto, isso significa dizer que o mundo não é como ele deve ser (que ele está em desacordo consigo mesmo, com seu próprio "conceito"), mas isso sem apelar a um ideal transcendente normativo de justiça (ou de algum outro "dever ser"), que se impõe aos objetos de forma externa a eles. A crítica (enquanto um juízo) extrai sua normatividade do objeto, de sua contradição imanente, da contradição entre ele e seu próprio conceito. Mas voltemo-nos ao texto de Hegel para entedermos como é diferenciada a verdade filosófica da verdade em seu sentido "trivial":

[...] deve-se saber o que se deve entender por "verdade". Chamamos comumente "verdade" a concordância de um objeto com nossa representação. Temos, nesse caso, como pressuposição, um objeto ao qual deve ser conforme nossa

\footnotetext{
${ }^{331}$ Marcuse, Hegels Ontologie und die Theorie der Geschichtlichkeit, p. 164.

${ }^{332}$ Hegel, Briefe II, 79 apud Marcuse, Hegels Ontologie und die Theorie der Geschichtlichkeit, p. 164.

${ }^{333}$ Marcuse, Reason and Revolution, p. 25.
} 
representação sobre ele. No sentido filosófico, ao contrário, verdade significa - expressa em geral abstratamente concordância de um conteúdo consigo mesmo. Assim, isto é uma significação da verdade totalmente diversa da mencionada anteriormente. Aliás, a significação mais profunda (filosófica) da verdade encontra-se parcialmente já no uso comum da linguagem. Fala-se, por exemplo, de um verdadeiro amigo; e se entende com isso, um amigo cuja maneira-de-agir é conforme ao conceito de amizade; igualmente se fala de uma verdadeira obrade-arte. Não-verdadeiro, então, quer dizer o mesmo que mau, inadequado em si mesmo. Nesse sentido, um mau Estado é um Estado não-verdadeiro, e o mau e o não-verdadeiro, em geral, consistem na contradição que tem lugar entre a determinação ou o conceito, e a existência de um objeto. Podemos fazer uma representação correta de um tal objeto mau, porém o conteúdo dessa representação é algo em si não-verdadeiro. ${ }^{334}$

Podemos dizer que alguma coisa é verdadeira quando ela se torna aquilo que ela $e ́$, quando ela se desenvolve plenamente de acordo com seu conceito. Ainda na Enciclopédia, Hegel retoma tal discussão mais adiante (repetindo mais ou menos o que ele havia dito antes):

Por verdade entende-se, antes de tudo, que eu sei como alguma coisa é. No entando, isso é a verdade só em relação à consciência; ou a verdade formal, a simples exatidão [Richtigkeit]. Ao contrário, no seu sentido mais profundo, consiste em ser a objetividade idêntica ao conceito. Trata-se desse sentido mais profundo quando, por exemplo, se fala de um verdadeiro Estado, ou de uma verdadeira obra de arte. São verdadeiros esses objetos quando são o que devem ser, isto é, quando sua realidade corresponde ao seu conceito. Assim compreendido, o nãoverdadeiro é o mesmo que aliás se chama o mau. [...] O que é totalmente mau, ou contrário ao conceito, é, justamente por isso, algo que em si mesmo se desagrega. ${ }^{335}$

Mas o que é, afinal, esse caráter de dever ser da verdade? Deve-se ressaltar que ele não é um ideal fixo, que paira acima da realidade. A crítica do puro dever-ser, da normatividade abstrata, é um dos motivos centrais da dialética. Na Fenomenologia do Espirito, Hegel escreve: “O que deve-ser, também é, de fato. O que apenas deve ser, sem ser, não tem verdade nenhuma." 336 A crítica do "puro dever-ser" é dirigida sobretudo a Kant, para quem as ideias (verdadeiras) são princípios regulativos, mas permanecem

\footnotetext{
${ }^{334}$ Hegel, Enciclopédia das ciências filosóficas em compêndio, p. 82.

${ }^{335}$ Hegel, Enciclopédia das ciências filosóficas em compêndio, p. 349-350.

${ }^{336}$ Hegel, Fenomenologia do Espírito, p. 185.
} 
apartadas do mundo. Como diz Marcuse, na filosofia kantiana "thought becomes estranged from reality and the truth becomes an impotent ideal preserved in thought while the actual world is calmly left outside its influence." ${ }^{337}$ Ou seja, esse teor normativo da verdade não deve estar completamente separado do mundo. E como explica Marcuse (em sua tese sobre Hegel de 1932): “o caráter de dever-ser [Sollenscharakter] não pode, naturalmente, ser compreendido no sentido de uma norma válida [geltenden], mas como uma determinação imanente ao ser do ente." 338 Notemos que na expressão "ser do ente" ressoa o heideggerianismo do jovem Marcuse - aliás, na resenha que Adorno escreve sobre esse livro de 1932 para o primeiro número da revista do Instituto de Pesquisa Social, ele critica os traços heideggerianos de uma interpretação "ontologizante" da dialética de Hegel, visto que, para Adorno, a dialética não é uma ontologia, mas seu exato oposto. $\mathrm{O}$ cerne do que diz Marcuse, entretanto, é central para a ideia de uma normatividade dialética: o "caráter de dever-ser" é algo que a própria coisa põe em movimento por meio de suas determinações internas, e não uma norma fixa, eterna e atemporal. No limite, podemos falar aqui de uma normatividade sem norma, que suge nesse movimento da contradição entre a coisa e seu conceito - entendendo aqui que o conceito não é nenhuma Ideia transcendente regulativa, mas é uma determinação objetiva da própria coisa. Ou seja, não se trata de dizer que a coisa é falsa e verdadeiro é o seu conceito (o que seria uma recaída em um idealismo de tipo platônico), mas sim que a verdade se revela na contradição. A contradição é, como diz Adorno, "organon da verdade”339. Ou seja, o que é normativo não é o conceito, que operaria como um "ideal", mas a própria contradição imanente à coisa e seu conceito que os põe em movimento (daí o caráter processual e "temporal" da verdade). Não é por acaso que Adorno termina uma de suas aulas (não são raras as vezes em que Adorno termina a aula com uma frase ao mesmo tempo sintética e impactante) dizendo: "Poderíamos então por fim dizer que a ideia hegeliana de contradição advém do próprio conceito enfático de verdade."340 Ou seja, se há uma dimensão utópica da verdade (de forma mais explícita em Bloch), é porque tal utopia não é nenhuma ideia transcendente, mas surge como aquilo que é fermentado nas contradições do presente.

\footnotetext{
${ }^{337}$ Marcuse, Reason and Revolution, p. 23-24.

${ }^{338}$ Marcuse, Hegels Ontologie und die Theorie der Geschichtlichkeit, p. 165.

${ }^{339}$ EiD, p. 100

${ }^{340}$ EiD, p. 104.
} 
Na introdução à Dialética Negativa, Adorno escreve: "Em face da possibilidade concreta da utopia, a dialética é a ontologia do estado falso."341 O falso, como diz Hegel, é também aquilo que é "mau", "algo que em si mesmo se desagrega". Ou seja, podemos dizer que a verdade desse estado de coisas falso é seu fim. Nos termos de Marcuse: "[Hegel's philosophy] is originally motivated by the conviction that the given facts that appear to common sense as the positive index of truth are in reality the negation of truth, so that truth can only be established by their destruction. ${ }^{\text {"342 }}$ Isto é, nessa processualidade do "cerne temporal da verdade", há um nexo entre verdade e destruição, uma verdade que se exprime no colapsar (zu Grunde gehen, que é ao mesmo tempo "ir ao fundamento"). $\mathrm{Na}$ Ciência da Lógica, Hegel escreve: “As coisas finitas são, mas sua relação consigo mesmas é que elas se relacionam negativamente consigo mesmas. Precisamente nessa relação consigo mesmas, elas se propelem além de si, além do seu ser. Elas são, mas a verdade desse ser é o seu fim." ${ }^{343}$ É evidente a afinidade entre essa consideração de Hegel sobre a finitude e o conceito de capital de Marx, cuja verdade é, nessa "relação negativa consigo mesmo" em suas contradições internas, precisamente, seu colapso. É somente na verdade da contradição que produz um fim que a utopia se torna, como diz Adorno, uma "possibilidade concreta".

\footnotetext{
${ }^{341}$ DN, p. 18.

${ }^{342}$ Marcuse, Reason and Revolution, 27.

${ }^{343}$ Hegel, Ciência da Lógica, p. 130 (tradução alterada). Também Marcuse comenta essa relação entre verdade e finitude em Hegel: "[...] all immediate forms of existence - in nature and in history - are ,bad', because they do not permit things to be what they can be. True existence begins only when the immediate state is recognized as negative, when beings become 'subjects' and strive to adapt their outward state to their potentialities." Mais diante: "[...] negativity is consitutive of all finite things" e por isso: "The negativity everything possesses is the necessary prelude to its reality." Marcuse, Reason and Revolution, p. 66
} 


\section{Capítulo 3 - Antinomias da moral}

\section{Origens da dialética entre moral e política}

"Não há vida correta na falsa": essa célebre frase da Minima Moralia, que chegou a ser repetida ad nauseam até mesmo em meios de comunicação de massa na Alemanha em situações como o aniversário de morte de Adorno (que a certa altura já havia sido transformado em patrimônio intelectual nacional) parece ser a palavra final do autor a respeito da (im)possibilidade de formulações que indicariam um modo moralmente correto de orientar as ações do indivíduo no mundo. Clichê ou não, a frase não deixa de ser significativa. Ela é exagerada, enfática: mas como vimos anteriormente, é próprio da verdade o elemento de exagero. Em um país como a Alemanha, onde o cidadão médio tem uma forte fixação às normas que garantiriam aos indivíduos um alto nível de segurança moral, a frase tem um efeito específico. Em um país periférico como o Brasil, onde não se formou um "nexo moral” (como diz Caio Prado Jr.) e onde não há essa brutal identificação entre povo e Estado ${ }^{344}$ (não se poderia esperar outra coisa de uma instituição colonial que só pode se constituir enquanto algo estranho ao povo, portanto opressivo), talvez essa frase soasse como uma banalidade, algo óbvio, pois a própria suspensão da norma é normal $l^{345}$. A indicação de que não há vida correta na falsa, antes de apontar para um relativismo moral, significa que não há vida correta nessa vida, e a própria frase possui, digamos, um "conteúdo normativo" contido na própria ideia de "vida falsa", pois a vida não deveria ser tal como ela é, em suma, ela deve ser transformada ${ }^{346}$. Se a essência da filosofia moral moderna gira em torno das determinações da ação individual, Adorno apontará sempre para a tensão entre o indivíduo e o todo (a vida social, o Estado, em suma, a sociedade como totalidade), em que o primado é, justamente, do todo ${ }^{347}$. Por isso, se há algo que se poderia chamar de "filosofia moral" em Adorno, ela só pode existir em uma relação de subordinação a uma compreensão da realidade social (que incorpora uma

\footnotetext{
${ }^{344}$ Lembrando o texto de Adorno "Individuum und Staat", citado anteriormente: tal identificação na Alemanha é patológica, portanto não se pode dizer que ocorre aí uma real identidade.

${ }^{345}$ Nesse sentido, a experiência colonial da periferia, em que a exceção é a regra, torna-se posteriormente paradigmática para a compreensão da verdade do centro.

${ }^{346}$ Como discutido no capítulo 2 , a noção de verdade (e de falsidade) na tradição hegeliana da teoria crítica vincula o momento descritivo (o que é) ao normativo (o que deve ser).

${ }^{347}$ Cf. Capítulo "Die Vormacht des Allgemeinen: Zur moralphilosophischen Dialektik des Individuums" in: G. Schweppenhäuser, Ethik nach Auschwitz: Adornos negative Moralphilosophie.
} 
teoria do indivíduo psicanaliticamente orientada), que por sua vez só pode existir enquanto crítica da sociedade.

Até aqui, nada que seja estranho a uma posição classicamente marxista: "moral" é ideologia da classe dominante ou coisa de religioso espiritualista, ou seja, um engodo, uma mentira que deve ser desmontada pela crítica materialista ${ }^{348}$. A verdadeira questão é a transformação da sociedade (que é injusta, imoral, privadora de liberdade etc), portanto o agir correto não é guiado por normas morais, mas por uma estratégia que encaminharia a realização de um fim: o fim das relações de dominação e a efetivação da liberdade. Ou seja, a dimensão propriamente moral não está na ação do indivíduo, mas na inteligência direcionada para a transformação do todo. É claro que as coisas se tornaram mais complicadas ao longo do século XX, e essa relação com a transformação do todo, ou seja, com a "práxis correta", que já era bastante mediada, não estava mais ao alcance da mão ${ }^{349}$. Além disso, o bruto estrategismo stalinista e o aniquilamento do indivíduo eram a expressão máxima dos horrores produzidos pela "razão de Estado", que se sobrepunha a qualquer moral individual. Porém, esta relação entre indivíduo e Estado, ou indivíduo e totalidade social, permanece no horizonte das reflexões de Adorno sobre a moral. Por exemplo, no curso "Problemas de filosofia moral" de 1962/63, após meses de acrobacia mental com incursões aprofundadas em Kant, Hegel e Schopenhauer, Adorno conclui a última aula da seguinte forma: "Resumidamente, o que a moral hoje ainda pode significar passa para a questão sobre o arranjo [Einrichtung] do mundo. Seria possível dizer: a questão sobre a vida correta seria a questão sobre a política correta, se uma tal política correta estivesse hoje no âmbito do que pode ser realizado [Bereich des zu

\footnotetext{
${ }^{348}$ Em aula, Adorno diz que a crítica à moral por parte de Nietzsche e Marx no século XIX (ele se refere em especial à era vitoriana) encontrava seu sentido no fato de a moral operar como uma "Fessel des Lebens", portanto, como sustentação de poder. No século XX essa relação se altera, devido à própria alteração da estrutura da ideologia (retornaremos a isso mais adiante"Hoje é exatamente o contrário. Hoje não é mais a vida que é acorrentada pelas prescrições morais, mas a esfera do moral [Moralischen], da auto-determinação dos homens, está acorrentada pelo poder da socialização em uma medida hoje muito mais intensa. O que se opõe ao moral, no sentido da autodeterminação do homem, não é mais tanto ideologia. As ideologias se transformaram em uma mera reduplicação daquilo que simplesmente é." Probleme der Moralphilosophie (1956/57), TWAA (doravante citado como PM 1), 22/12/1956.

${ }^{349}$ Sobre isso, Adorno diz em uma carta de 1948 a Marcuse"Eu não temo muito a objeção que Korsch fez contra a Dialética do Esclarecimento - de que ao abrir mão da relação transparente à práxis política nós teríamos recaído em um ponto de vista pré-marxista, em um hegelianismo de esquerda à la Bruno Bauer. Pois justamente para o pensamento marxista consequente não é mais possível uma conexão com um 'movimento' prático no sentido antigo [...]. Não se pode falar como antigamente, como se a unidade entre teoria e práxis estivesse garantida." Briefe, TWAA.
} 
Verwirklichenden]. Agradeço a atenção de vocês e desejo-lhes boas férias." ${ }^{350}$ Em outro curso, de mesmo título mas dado em 1956/57, Adorno faz a seguinte consideração sobre a razão de Estado:

A razão de Estado é a expressão da objetividade do social que não deve ser medida de forma imediata na moral [Moralischen], nessa medida há em seu reconhecimento sempre um momento de verdade. Isso quer dizer: no conceito de razão de Estado há tanto do bom [Guten] e do correto, que as leis objetivas do comportamento social não devem ser medidas na moralidade, $\mathrm{e}$ que a possibilidade do bem pode ser produzida somente por meio dessa objetivação, dessa alienação das relações sociais e de suas exigências da consciência moral individual, somente por meio da política enquanto luta de poder. Somente se a luta política enquando luta de poder for conduzida até o final podem ser produzidas objetiva e socialmente as condições, por meio das quais seria então possível algo como uma postura moral individual, uma vida correta. O moral [Moralische] permanece relativo à esfera privada, daí sua fraqueza, pois a esfera privada é hoje mais do que nunca uma função da objetividade social. ${ }^{351}$

É dessa impotência da moral, que permance sempre vínculada à privacidade, que deriva o desinteresse histórico do marxismo pelas especulações morais. A ideia moderna de moral é, portanto, inseparável da constituição do indivíduo moderno e de uma esfera privada apartada da esfera política. Mas essa separação entre a instância privada e a esfera pública corre junto à tensão entre o indivíduo e o todo, que é por sua vez análoga a "essa contradição entre o universal e o particular [que] determina a antinomia fundadora do

\footnotetext{
${ }^{350}$ PdM, p. 262.

${ }^{351}$ PM 1, 26/02/1957. Esse primado do Estado sobre a ação individual aparece em Hegel, que diz em tom de zombaria em relação ao bem-fazer do indivíduo que age por amor ao próximo: "Mas o bem-estar essencial e inteligente é, em sua figura mais rica e mais importante, o agir inteligente universal do Estado. Comparado com esse agir, o agir do indivíduo como indivíduo é, em geral, algo tão insignificante que quase não vale a pena falar dele." Hegel critica aqui o dever de amar o próximo assim como ele critica toda moralidade abstrata, que, diversamente do agir do Estado, permanece aquém de toda realidade efetiva e racional: "tais leis ficam somente no dever-ser, mas não têm nenhuma efetividade: não são leis, mas apenas mandamentos." Hegel, Fenomenologia do Espírito, p. 296. Por outro lado, em outro momento, Adorno faz a seguinte consideração sobre a razão de Estado: "Deveria tratar-se criticamente - apenas para fornecer um modelo - um conceito tão respeitável como o de razão de Estado: quando se coloca o direito do Estado acima do dos membros da sociedade, já está colocado, potencialmente, o horror." Adorno, "Educação após Auschwitz", p. 123.
} 
moral [des Moralischen]" ${ }^{\prime 352}$, da qual fala Adorno. Acompanhando o argumento de Koselleck, a separação entre moral e política é concomitante à gênese da ideia de crítica no século XVIII. A instância moral que se separa do Estado faz do Estado um objeto do julgamento, e ela passa a existir enquanto crítica do Estado.:

A crítica política não reside somente no juízo moral enquanto tal. Está presente no momento em que se executa a separação entre uma instância moral e uma instância política: o tribunal moral transforma-se em crítica política, não só por submeter a política a um juízo severo, mas também, pelo contrário, por separar-se como instância que tem a faculdade de julgar o domínio da política. Esta separação já encerra a crítica ao Estado. [...] A divisão dualista do mundo em um domínio da moral e um domínio da política é, em sua historicidade, o pressuposto e a consequência da crítica política. [...] [A] crítica política só podia fundar-se em uma realidade histórica em que a moral e a política estivessem, de fato, separadas. ${ }^{353}$

O elemento político da moral está, portanto, em seu caráter apolítico. O agravamento da crise que antecedeu a Revolução Francesa foi estimulado pela exacerbação da "dialética da moral e da política",354, em que se agudizava a tensão entre sociedade e Estado. As lojas maçônicas, que tiveram função importante no processo de crise do Absolutismo, eram a "liberdade em segredo", o próprio "segredo da liberdade", que se formavam enquanto um "foro privado" moral. "A legalidade interna, a liberdade e a autonomia das lojas só eram possíveis num domínio que escapasse à influência das instâncias clericais e à intervenção política do poder estatal vigente. Por isso, desde o início, o segredo tinha uma função de rejeição e proteção." ${ }^{355}$ Este foro privado da moral era a mesma instância privada em que ocorria a crítica. Como aponta Habermas em Transformação estrutural da esfera pública, a crítica, antes de se tornar pública e política, era uma atividade privada:

Bayle separou a crítica de sua origem histórica e filológica, transformando-a simplesmente em crítica [...]. No entanto, considerava a atividade da crítica algo estritamente privado.

\footnotetext{
${ }^{352}$ PM 1, 04/12/1956 apud Schweppenhäuser, Ethik nach Auschwitz, p. 178.

${ }^{353}$ Koselleck, Crítica e Crise, p. 92.

${ }^{354}$ Ibid., p. 111.

${ }^{355}$ Koselleck, Crítica e Crise, p. 65.
} 
[grifo meu] [...] Crítica no que diz respeito ao interior, a raison permanece subalterna no exterior. Assim como na conscience em Hobbes, a critique em Bayle é um assunto privado e sem consequências para o poder público. Assim, ele também diferencia critique de satires e libelles diffamatoires. A crítica que comete o equívoco de transpor os limites da política degenera em panfleto. ${ }^{356}$

A esfera privada da moral e da crítica tornava-se o lugar natural de uma burguesia oposicionista. ${ }^{357}$ Se quando Adorno diz que "a esfera privada é hoje mais do que nunca uma função da objetividade social", devemos ter em vista que, ao mesmo tempo, é dessa mesma esfera privada enquanto algo separado da política e do Estado que surge o elemento de tensão na crise do século XVIII. A crítica oscila entre a moral e a política assim como entre o privado e o público. Entretanto, se o "reino da crítica" se consolida como uma esfera separada do Estado, em um dado momento esse limite é ultrapassado. A razão de Estado é submetida à Razão - e como afirmava Adorno, "pouco exagera quem equipara o conceito moderno de razão com crítica." ${ }^{358}$. O "tribunal da crítica" submete tudo e todos ao seu rigoroso juízo, e, tal como esperava Voltaire, "varrerá a tolice do mundo" ${ }^{\$ 59}$. Em 1781, no prefácio à Crítica da Razão Pura, Kant anunciava:

Nossa época é a verdadeira época da crítica, a que tudo deve se submeter. A religião, pela sua santidade, e a legislação, pela sua majestade, querem em geral subtrair-se a ela. Então suscitam contra si a justa suspeita e não podem reivindicar o sincero respeito que a razão só concede àquele que pôde suportar seu exame livre e público. ${ }^{360}$

No momento em que o juízo privado extrapola os limites da moral separada da política, a crítica torna-se pública e busca impor a ordem da razão, cuja universalidade faz tabula rasa nas hierarquias sociais calcadas no poder da corte e do clero. Na

\footnotetext{
${ }^{356}$ Habermas, Transformação estrutural da esfera pública, p. 245.

357 “A burguesia moderna certamente nasce do foro interior secreto de uma moral de convicção privada e se consolida nas sociedades privadas [...]. Os maçons burgueses não renunciam ao segredo do interior moral, pois nele encontram a garantia de sua existência independente do Estado." Koselleck, Crise e crítica, p. 68.

${ }^{358}$ Adorno, "Kritik"

359 "A crítica é a décima musa que finalmente apareceu [...] e varrerá a tolice do mundo." "A crítica tem razão; eu a amo e a honro. A plateia esclarecida julga os combatentes, e a razão sadia triunfa com o tempo." Apud Koselleck, Crítica e Crise, p. 102.

${ }^{360}$ Kant, Crítica da Razão Pura, AXI.
} 
Enciclopédia, Diderot e D’Alembert escrevem que a crítica é “capaz de distinguir a verdade da opinião, o direito da autoridade, o dever do interesse, a virtude da própria glória, em uma palavra: capaz de reduzir o homem, fosse ele quem fosse, à condição de cidadão. "361 Marx, que não poupou as “armas da crítica”, levou a politização da crítica a tal ponto que já não se temia a dissolução dos limites entre crítica, libelo e sátira ${ }^{362}$, tal a confluência entre ciência e combate. O juízo da crítica é um ataque. Aqui a moral de convicção privada já ficou para trás e adentra-se o campo aberto da batalha política.

\section{Uma espécie de dignidade da vida privada}

Enquanto reflexão retrospectiva sobre a derrota política, o texto adorniano se situa no momento preciso em que a transformação do mundo havia fracassado e o campo público da batalha política se fecha: o pensamento estratégico é empurrado de volta para a moral. Ou seja, a moral ganha sentido sobretudo enquanto reflexão sobre a derrota política (que não significa aceitá-la como definitiva, pelo contrário): trata-se de uma retirada estratégica. ${ }^{363}$ Adorno diz em aula: "Se por um lado a vida correta está bloqueada ao indivíduo, por outro, a esfera da 'atuação pública' [öffentlichen Wirkens], da atividade pública, tornou-se tão problemática, que, frente a ela, a esfera privada, em um certo sentido delicado a ser compreendido de forma cautelosa, ganha uma espécie de dignidade, que ela talvez tenha tido com os estóicos." 364 Se esse é o ponto de partida, não

\footnotetext{
${ }^{361}$ Diderot e D'Alembert, “Crítica”, Enciclopédia p. 84.

${ }^{362}$ Diferentemente de Voltaire e Bayle: "Como Bayle, Voltaire também recorreu, em 1733, à distinção entre 'la critique, la satire et la libelle' para justificar o caráter apolítico da sua crítica." Koselleck, Crítica e Crise, p. 101.

${ }^{363}$ Vagner Camilo utilizou o termo "retirada estratégica" para interpretar a assim chamada "guinada pessimista" ou "metafísica" do Drummond de Claro Enigma (que teria se distanciado da lírica engajada de $A$ Rosa do Povo). Com isso, Camilo visa dissipar a aura de despolitização resignada que paira sobre esse período da poesia de Drummond e apontar o sentido político (e estratégico, inclusive) desse livro, que aliás tem como epígrafe a frase de Valéry: "Les événements m'ennuient." Camilo lê essa saída da "praça de convites" enquanto uma retirada estratégica nos seguintes termos: "A atitude, portanto, nada tem de meramente demissionária. É antes produto de uma percepção mais ampla e distanciada da História, que abarca além do 'estreito rio presente'. Uma História que se revela regida por atos recorrentes e por uma 'cega destinação' (segundo a expressão de Luís Costa Lima) contra a qual todo esforço de transformação tende inevitavelmente ao fracasso, de onde o tão propalado pessimismo emergente nessa fase da obra." Vagner Camilo, Drummond: Da Rosa do Povo à Rosa das Trevas, p. 19. No caso de Adorno, ocorre algo semelhante nessa retirada da política para a moral: assim como em Drummond, ela não é "demissionária", mas permanece ligada a um sentido estratégico frente a uma situação em que a dimensão política mais imediata está, por ora, condenada (o que, entretanto, não é nenhum culto da derrota, muito pelo contrário).

${ }^{364}$ PM 1, 29/11/1956.
} 
causa espanto que as antinomias da moral em Adorno sempre apontem de volta para a prática socialmente transformadora. Mesmo no mergulho micrológico no âmbito da vida privada em um livro como Minima Moralia, as digressões sobre o casamento ${ }^{365}$, os gestos $^{366}$, o ato de dar presentes ${ }^{367}$, os cumprimentos, ${ }^{368}$ o tato, as habitações ${ }^{369}$ e a relação com objetos domésticos são intercaladas com reflexões mais gerais sobre a sociedade e a história em uma espécie de metafísica dos costumes reificados. Depois de ler o livro, Marcuse escreve a Adorno: "Há coisas ali que realmente tocam no limite do dizível e mesmo assim saem bastante claras. Penso que o mais impressionante é o jogo que tece sem atritos o que é muito pessoal e o universal." ${ }^{\text {370 }}$

No subtítulo do livro, Reflexões a partir da vida danificada, é possível entrever o interesse na crítica àquilo que infligiu os danos à vida (algo que exige, portanto, esforço teórico), e não em um retorno efetivo à moral da vida privada. Afinal, uma tal moral já não seria mais possível e nem faria sentido algo, pois, segundo seu diagnóstico, essa esfera privada da moral fora liquidada. "A esfera inteira da moral [Moralischen] é tão reduzida que ela na verdade está liquidada enquanto esfera. Na verdade, como Horkheimer formulou, não há mais pessoas boas ou más. As possibilidades objetivas da decisão moral estão encolhidas." ${ }^{371}$ Isso é decorrente do destino que tomou a própria ideia de indivíduo: “A liquidação social do indivíduo enquanto um indivíduo em si

\footnotetext{
${ }^{365}$ Cf. aforismos "Separado-junto", "Cama e mesa" e "Inter pares", MM p. 27-29.

366 "A tecnificação torna entrementes os gestos precisos e rudes, e com isso os homens. Ela expulsa dos movimentos toda hesitação, toda ponderação, toda urbanidade [Gesittung]. Decisivas são as exigências irreconciliáveis e como que a-históricas das coisas. Desaprende-se a fechar uma porta com suavidade e cuidado e mesmo assim com firmeza. [...] Nos movimentos que as máquinas exigem dos seus operadores já está o violento, o brutal, o percussivamente interminável dos maus tratos fascistas." MM, p. 36.

367 “'Os homens desaprendem a dar presentes." Cf. aforismo "Não se aceita troca”, MM, p. 38-39. 368 " "....] a delicadeza entre pessoas nada mais é do que a consciência da possibilidade de relações desprovidas de fins, que toca consoladoramente mesmo quem está enleado na finalidade; herança de velhos privilégios que promete a condição sem privilégios. A eliminação do privilégio pela razão burguesa acaba por eliminar também a promessa. Se tempo é dinheiro parece moral economizar tempo, sobretudo o próprio, e desculpa-se tal parcimônia como consideração pelos outros. É-se direto. Cada hiato que se interpõe nas relações dos homens é sentido como perturbação no funcionamento do aparato, em relação ao qual não somente se está objetivamente integrado como orgulhosamente identificado. Que ao invés de tirar o chapéu os homens se cumprimentem com a aura da indiferença habitual, que o invés de cartas eles troquem office communications sem cabeçalho e sem remetente são sintomas entre outros de um esfriamento do contato." MM, p. 37. Notemos que na maioria dessas considerações, está em questão o efeito da frieza burguesa sobre a vida.

${ }^{369}$ Cf. aforismo "Asilo para desamparados". MM, p. 34-35.

${ }^{370}$ Carta de Marcuse a Adorno de 06/02/1948. TWAA Br.

${ }^{371}$ PM 1, 22/12/1956.
} 
subordinado [gefügten] é equivalente à liquidação da esfera moral enquanto tal." ${ }^{, 372}$ Isto é, a liquidação da esfera moral é a liquidação da diferença entre as normas que o indivíduo põe para si e as normas sociais. As normas sociais (no caso, a dominação social) são internalizadas e tornam-se normas subjetivas, de modo a tendencialmente anular a contradição entre o indivíduo e o todo, uma vez que o indivíduo torna-se "apêndice da maquinaria"373 no sentido mais brutal, a saber, nessa transformação das regras sociais, que são puramente funcionais, nas regras do próprio indivíduo:

Pertence ao estado atual da consciência moral que as pessoas não só refletem-se nessa situação, como, a partir de dentro, identificam-se nela, de modo que as normas, que os coagem por meio dessa situação de heteronomia, tornam-se suas próprias normas. As categorias da heteronomia são internalizadas e tornam-se categorias da própria autonomia. (Sentem-se ainda como funcionários diante do onipotente). Pertence à marca dessa época que as pessoas não mais agem no sentido de decisões morais ou outras, mas funcionam somente como apêndices da maquinaria. A funcionalização do homem tornou-se universal. Há uma diferença qualitativa do empresário autônomo, que era de fato um agente do capital, mas isso era um processo longo com muitas mediações. O que mudou não é tanto o caráter funcional da pessoa frente aos processos econômicos, mas que esses estímulos funcionais [Funktionsvorschläge] se transformaram imediatamente em imperativos, de modo que as pessoas fazem exatamente aquilo que é esperado delas. ${ }^{374}$

\section{Declínio da eticidade}

Quando desaparece a situação normal, desaparece com ela o pressuposto de toda norma ética e de toda norma jurídica. Carl Schmitt

\footnotetext{
${ }^{372}$ PM 1, 21/02/1957. A liquidação da esfera privada é analisada na transformação das habitações: "O destino reservado à vida privada hoje é demonstrado pelo seu cenário. Na realidade nem se pode mais morar. [...] A casa é coisa do passado.” MM, p. 34-35.

${ }^{373} \mathrm{Na}$ "Dedicatória" da Minima Moralia, ao falar sobre "a doutrina da vida certa", Adorno diz: "Aquilo que outrora o filósofo entendia por vida, reduzido à esfera privada e depois só à do consumo, vê-se arrastado, sem autonomia e sem substância própria, como apêndice do processo de produção material." MM, p. 9.

${ }^{374}$ PM 1, 22/12/1956.
} 
Sim, não havia nada que impedisse as SS de fazer o que faziam: não existe direito natural; as categorias morais nascem e morrem como as modas.

Jean Améry

Nessa situação, não há nenhuma eticidade substancial, nenhuma Sittlichkeit à qual os individuos possam referir suas ações ${ }^{375}$. A descrição da vida danificada na Minima Moralia é o atestado disso. Se em Hegel a eticidade era uma espécie de "cimento social", para Adorno, hoje, "o cimento entre os homens é substituído pela pressão que os mantém juntos." ${ }^{376}$ Em uma aula do curso de 1962, ele diz de forma clara: "Eu diria que o motivo pelo qual a questão da filosofia moral se tornou tão radicalmente problemática é, em primeiro lugar, o fato que a substancialidade dos costumes, ou seja, que a possibilidade de uma vida correta nas formas nas quais a comunidade existe já estivesse dada e presente tornou-se radicalmente inválida: ela não existe, e não se pode fiar nela hoje de modo algum." 377 A ideia de uma "substancialidade dos costumes" aqui é a própria ideia hegeliana de eticidade (que Hyppolite traduz como "ordem ética"). ${ }^{378}$

Ao mesmo tempo, no curso de 1956, Adorno diz que a própria ideia de "filosofia moral" está vinculada a um declínio da eticidade, isto é, como se ela aparecesse justamente como reação à ausência de substancialidade dos costumes: "Filosofia moral está ligada ao abalo [Erschütterung] dos costumes, isto é, ao declínio de uma forma de vida na qual os homens se movimentam de forma evidente." ${ }^{, 379}$ Por um lado, podemos

\footnotetext{
${ }^{375}$ Adorno vai completamente na contramão do que Axel Honneth vem tentando desenvolver ao tentar recuperar a ideia hegeliana de Sittlichkeit. Se Adorno via a impossibilidade de se remeter à eticidade no capitalismo, Honneth, ao contrário, busca encontrar um mundo ético e uma "esfera de liberdade social" na própria economia de mercado - algo que também Habermas não ousaria fazer, pois para ele o "sistema poder-dinheiro" configurava um conjunto de normas ao qual o mundo da vida deveria oferecer resistência. Em Honneth essa divisão habermasiana é desfeita e a economia torna-se uma esfera ética do mundo da vida. Nessa tentativa forçada de legitimar moralmente o capitalismo, Honneth retorna à Teoria dos sentimentos morais de Adam Smith, a fim de demonstrar inclusive como o capitalismo produz, apesar de tudo, sentimentos morais e laços sociais. A crítica da economia política é substituída agora por uma "filosofia da economia". Cf. Axel Honneth, Freedom's Right: on the Foundations of Democratic Life. Cambridge: Polity, 2014.

${ }^{376}$ MM, p. 37.

${ }^{377}$ PdM, p. 21-22.

378 "Dans la Phénomenologie l'esprit est la substance éthique, la vie d'un peuple libre, dans lequel chaque conscience singulière existe comme reconnue par les autres; ou, pourrait-on encore dire, existe par son lien ontologique avec les autres consciences singulières. [...] c'est dans la vie organique d'un peuple que cet esprit se réalise complètement." Hyppolite, Genèse et structure de la Phénoménologie de l'Esprit de Hegel, p. 264.

${ }^{379}$ PM 1, TWAA, 13/11/1957.
} 
pensar que a filosofia moral aparece como reação ao "estado de exceção moral" (ao qual se refere Schmitt, na citação da epígrafe acima). Por outro lado, a ideia de moral seria necessariamente, portanto, uma oposição aos costumes em funcionamento, ou seja, não se trata de uma postura melancólica frente à eticidade nem de um desejo de restaurá-la. Brecht colocou essa crítica ao costume de forma bastante clara quando escreveu a peça Aquele que diz sim/aquele que diz não: o ato moral ocorre quando o menino diz não ao "grande costume", segundo o qual ele deveria ser sacrificado (em nome de um dever maior), apesar de isso tê-lo levado, no final, à humilhação diante da comunidade. É da natureza da moral a possibilidade de contestar as normas sociais, que não devem aparecer como imutáveis. No mesmo curso de 1956, Adorno afirma coisa semelhante: "Filologicamente, moral vem de costumes [Sitten]: mores, em alemão, eticidade [Sittlichkeit]. Há aí um certo mal-estar, pois nossa própria representação do bem [Guten] se opõe de forma quase evidente àquilo que é chamado de costume. O que é moral ou bom [das Gute] é aquilo que experimentamos como bom [gut], em oposição a isso o costume é algo externo [Äußerliches], questionável." ${ }^{„ 80}$ Adorno nota ainda o teor irracional dos costumes, em seu caráter de tabu: "Os mores são obrigatórios por meio de sua existência. Costumes, normas já válidas em uma sociedade, têm caráter de tabu que contradiz a legitimação teórica - [é sem sentido] deduzir por meio da razão aquilo que extrai seu próprio direito a partir da mera existência."381 Adorno provavelmente concordaria aqui com Nietzsche, para quem eticidade não é nada senão obediência aos costumes. ${ }^{382}$ Judith Butler, lendo as aulas de Adorno, chamou essa eticidade que perde a sua substancialidade, que são normas da coletividade que perdem seu real caráter de coletividade, de violência ética:

[...] he makes clear that although the collective ethos is no longer shared - indeed, precisely because the collective ethos, which must now be herded by quotation marks, is not commonly shared - it can impose its claim to commonality only through violent means. In this sense, the collective ethos instrumentalizes violence to maintain the appearance of its collectivity. Moreover, this ethos becomes violence only once it has become an anachronism. What is strange historically - and temporally about this form of ethical violence is that although the collective

\footnotetext{
${ }^{380}$ PM 1, 06/11/1956.

381 PM 1, 06/11/1956.

382 “[...] a eticidade não é outra coisa (e, portanto, não mais!) do que obediência a costumes, não importa quais sejam." Nietzsche, Aurora. Nesse sentido, os costumes (e a moral em geral) são, para Nietzsche, o oposto da liberdade.
} 
ethos has become anachronistic, it has not become past; it insists itself into the present as an anachronism. The ethos refuses to become past, and violence is the way in which it imposes itself upon the present. ${ }^{383}$

Não há como deixar de entrever aí o embate norte-americano entre liberais e conservadores, entre formas de vida "progressistas" (Adorno se refere às "forças produtivas sociais"[!]) e aquele "moralismo" (próprio também dos teóricos da decadência que lamentam o "declínio moral"), entendido como o apego antiquado a normas e costumes que acabam assumindo um caráter coercitivo justamente por seu "anacronismo", como diz Butler. O argumento, em seu horizonte progressista, é dualista e vê uma dimensão da violência das sociedades modernas como um arcaísmo, um resto do passado do qual precisaríamos nos livrar, para podermos, enfim, realizar a eticidade democrática (como diria Honneth). Algo que parece inadequado diante do recrudescimento contemporâneo dessa "violência ética" (como a perseguição aos dissidentes da norma sexual, por exemplo), que pode ser interpretado não tanto como uma persistência anômala de valores morais anacrônicos, mas sim como algo que encontra sua lógica na crise do contemporâneo (tomemos como exemplo o novo fundamentalismo islâmico ou os evangélicos neopentecostais, que de arcaicos não têm nada). ${ }^{384}$ De todo modo, com o termo "violência ética", também Butler não deseja abandonar a ética, mas apontar o não-ético na ética de acordo com suas próprias normas. ${ }^{385}$ Afinal, violência ética (no sentido de opressão) seria uma contradição em termos, uma vez que a ética, em sua essência, é crítica da opressão: "Na medida em que a antimoral repudia o imoral da

\footnotetext{
${ }^{383}$ Judith Butler, Giving an account of oneself, p. 4-5. O trecho de Adorno ao qual Butler se refere é o seguinte: “ [...] provavelmente não há nada mais 'degenerado' [zersetzter] que o tipo de ética ou moral que sobrevive na forma de ideias coletivas depois que o espírito do mundo já não está mais com elas, se me for permitido falar hegelianamente e de modo bastante breve. Quando o estado da consciência dos homens e também o estado das forças produtivas sociais já se distanciaram dessas ideias coletivas, então essas ideias assumem algo de violento e repressivo. E o que força a filosofia em direção às reflexões, tais como as que queremos trazer aqui, é precisamente essa coerção que reside nos costumes, aquilo que é violento e mau nos costumes, que eles trazem em oposição à eticidade - e não por exemplo a mera decadência [Verfall] dos costumes, como se queixam os teóricos da decadência [Dekadenztheoretiker].” PdM, p. 32.

${ }^{384} \mathrm{Ou}$ seja, não se trata de um embate entre uma eticidade moderna, democrática e uma arcaica, violenta, como fazem crer os atuais teóricos das guerras culturais e do progressismo moral. A crítica adorniana à eticidade não é uma crítica do "atraso moral".

${ }^{385}$ Como diz Adorno, trata-se não de "descartar ou abolir a moral, mas de confrontá-la com seu próprio conceito: a moral [Moral] é moral [moralisch]?" 26/02/1957, PM 1.. Esse seria o sentido de uma crítica imanente da moral: "Quando uma filosofia moral como a kantiana é criticada enquanto ideologia, então a relação da verdade a essa ideologia não seria simplesmente descartála, mas realizá-la." 29/01/1957, PM 1.
} 
moral, a repressão, ela no mesmo passo incorpora o mais íntimo desejo da moral: o de que com toda constrição também desapareça toda violência."386

\section{A lei do coração e o curso do mundo: protesto moral e utopia}

Nada é belo, só o que não existe.

Rousseau, Nova Heloísa

Em 1966, no ano de publicação da Dialética Negativa, Adorno organiza uma edição alemã da obra Théorie des quatre mouvements et des destinées générales de Charles Fourier, precedida por um estudo introdutório de sua orientanda Elisabeth Lenk, que desenvolvia em Frankfurt uma tese sobre o surrealismo francês ${ }^{387}$. Essa coincidência entre a publicação de um livro rigoroso sobre dialética, de um lado, e do outro, uma tradução de um socialista utópico, deve ser considerada. No prefácio a essa edição de Fourier, Adorno escreve:

Sobre o conteúdo e a interpretação teórica dos Quatre Mouvements não há nada a acrescentar à introdução. Que somente seja dito: face à dogmatização dos teoremas marxistas, que ocorre por razões políticas no bloco de poder do leste, certos pensamentos ganham renovada atualidade, que já muito antes e não somente nessa região foram desprezados como utópicos. Entre os utopistas, o não revolucionário Fourier assume uma posição extrema. Ninguém se apresenta à acusação de utopismo de forma mais indefesa que ele; também para ninguém a predisposição da doutrina é tão produzida pela vontade de concretizar a representação de uma situação melhor. A proibição de pensar como deveria ser, a cientifização do socialismo não serviu para o bem deste. $\mathrm{O}$ veredito sobre a fantasia como fantasiação colou-se a uma práxis que era um fim em si e que estava mais presa no existente, para além do qual ela quis ir outrora. $^{388}$

Gostaria de dizer, em uma fórmula um pouco estranha, que há em Adorno uma dialética entre socialismo utópico e socialismo científico. É claro que a relação entre

\footnotetext{
${ }^{386}$ MM, p. 91.

${ }^{387} \mathrm{Na}$ correspondência entre Lenk e Adorno há inclusive um intenso debate sobre o surrealismo.

${ }^{388}$ Adorno, "Vorwort zur deutschen Übertragung der Quatre Mouvements von Charles Fourier", GS 20.2, p. 699.
} 
utopia e ciência ${ }^{389}$ é o problema maior da ideia de teoria crítica e do marxismo, que, como diz Bloch, "resgatou o núcleo racional da utopia". ${ }^{390}$ Se os utópicos viviam de um "ideal", abstrato e sem lastro na realidade - daí o sentido pejorativo de "utopismo" ou "moralizante", pois recairia em um "puro dever-ser sem ser", como diria Hegel - o marxismo visa a transformação da realidade, daquilo que é, de modo a criar um vínculo entre o que é e aquilo que não é, ou que ainda não é, mas que deve ser. Daí a necessidade, segundo Bloch, de uma objetividade da fantasia, que, embora objetiva, deve também poder vincular-se ao que não existe, de modo a dar-lhe dignidade de realidade. Dito de outra forma, trata-se do vínculo entre o presente e o não presente, de modo que o futuro torna-se inteligível, como dizia também Bloch. Mas a grande questão para Adorno é que esse lastro na realidade da utopia se tornou problemático, e o vínculo entre o que ainda não é (a liberdade) e o que é (a não-liberdade) parece perdido em algum lugar. Nesta

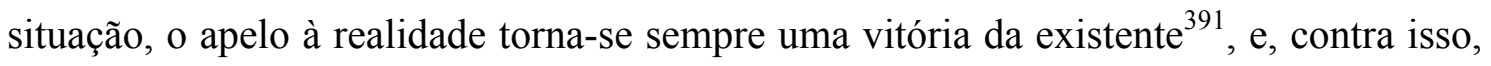

${ }^{389}$ Entende-se ciência aqui no sentido do ideal filosófico de objetividade, e não como fixação positivista ao método, tampouco como fetichismo dos fatos.

${ }^{390}$ PE, p. 141.

${ }^{391}$ Mesmo Lenin se indignou com o anti-utopismo de socialistas russos que viam os devaneios e sonhos de forma pejorativa: “'Com o que devemos sonhar?' Escrevo estas palavras e de repente fico assustado. Imagino-me sentado no Congresso de Unificação, tendo à minha frente os redatores e colaboradores do Rabotscheje Djelo. E eis que se levanta o camarada Martynov e, ameaçador, dirige-me a palavra: 'Mas permita-me perguntar! Uma redação autônoma ainda tem o direito de sonhar sem ter comunicado tal fato aos comitês do Partido?' Depois, é o camarada Krischevski que se dirige a mim e (aprofundando filosoficamente o camarada Martynov, que há muito já aprofundara o que havia dito o camarada Plekhanov) continua ainda mais ameaçador: 'Irei ainda mais longe. Pergunto-lhe: se um marxista tem algum direito de sonhar, a não ser que esqueça que, depois de Marx, a humanidade sempre se atribui tarefas realizáveis, e que a tática é um processo de crescimento das tarefas que crescem junto com o Partido?' À simples ideia dessas questões ameaçadoras, sinto um calafrio, e penso apenas em uma coisa: onde me esconder. Tentemos nos esconder atrás de Pissarev. 'Há desacordos e desacordos', escrevia Pissarev sobre o desacordo entre o sonho e a realidade. 'Meu sonho pode ultrapassar o curso natural dos acontecimentos, ou desviar-se em uma direção para onde o curso natural dos acontecimentos jamais poderá conduzir. No primeiro caso, o sonho não produz nenhum mal, pode até sustentar e reforçar a energia do trabalhador (...) Em tais sonhos, nada pode corromper ou paralisar a força de trabalho; ao contrário. Se o ser humano fosse completamente desprovido da faculdade de sonhar assim, se não pudesse de vez em quando adiantar o presente e contemplar em imaginação o quadro lógico e inteiramente acabado da obra que apenas esboça em suas mãos, eu decididamente não poderia compreender o que leva o ser humano a empreender e realizar vastos e fatigantes trabalhos na arte, na ciência e na vida prática (...). O desacordo entre sonho e realidade nada tem de nocivo se, cada vez que sonha, o ser humano acredita seriamente em seu sonho, se observa atentamente a vida, compara suas observações com seus castelos no ar e, de uma forma geral, trabalha conscientemente para a realização de seu sonho. Quando existe contato entre o sonho e a vida, então tudo vai bem.' Infelizmente, há poucos sonhos dessa espécie em nosso movimento. E a culpa é sobretudo de nossos representantes da crítica legal e do 'seguidismo' ilegal, que se gabam de sua ponderação, de seu 'senso' de 'concreto'.” V. I Lenin, Que fazer? Apud PE, p. 20-21. 
reaparece no espírito utópico de Adorno a "lei do coração" e o protesto contra o mundo. Com isso, há um retorno de figuras hegelianas da não-reconciliação (contra a reconciliação extorquida ${ }^{392}$ ): a crítica, a moral, o não-idêntico, o indivíduo, e temas românticos como a Weltschmerz ("o que há de doloroso na dialética é a dor em relação a

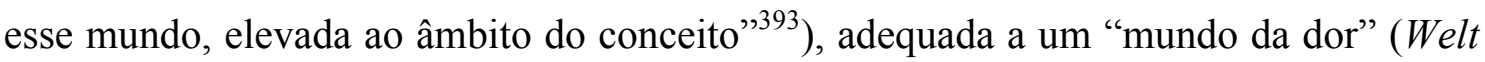
des Schmerzes) - embora tais figuras não devam ser, em hipótese alguma, absolutizadas. ${ }^{394}$ Retorna igualmente aquilo que os socialistas "científicos" criticam no socialismo utópico, a saber, uma certa tendência moralizante ou recusa "abstrata" do capitalismo enquanto forma de vida, que é uma vida degradada e não uma que contém o germe de uma outra melhor - diferentemente do que pensam os "científicos", para quem o capitalismo faz parte de um progresso doloroso mas necessário para alcançar a sociedade emancipada. ${ }^{395}$ Daí a analogia entre o desprezo dos socialistas "científicos" pelos "utópicos", vistos como infantis, e aquilo que Hegel critica na "lei do coração" que se mantém em um embate com o curso do mundo, incapaz de aceitar seu destino. ${ }^{396}$ Mas o destino tanto de um quanto de outro é a derrota (no caso dos "utopistas infantis", "esquerdistas", "revisionistas" etc. - o gulag), pois em Hegel o mundo deve deixar de ser, para a consciência, uma resistência a ser vencida. ${ }^{397}$ É contra essa vitória do curso do mundo, que se revela como o "mal efetivado", que Adorno dirige seus esforços. A esta altura, o espírito do mundo hegeliano revelou-se como o imparável desenvolvimento das forças destrutivas do capitalismo. "O que para Hegel era o espírito do mundo, o grande

\footnotetext{
${ }^{392}$ Adorno, "Erpreßte Versöhnung" in Noten zur Literatur, GS 11.

${ }^{393}$ DN, p. 14.

${ }^{394}$ Adorno vê uma função crítica do indivíduo ao mesmo tempo em que ele critica o principium individuationis e os limites que ele põe à subjetividade. Nesse contexto, há de se notar que, para Adorno (e isso é um problema a ser elaborado), a ideia de coletivo só aparece sob a figura da regressão. Entretanto, há de se notar que essas figuras do coletivo regressivo são produzidas também pela forma da individualidade burguesa, isto é, o coletivo só existe enquanto um bando de mônadas, ou seja, desprovido de uma natureza verdadeiramente coletiva.

${ }^{395}$ De forma análoga, Amaro Fleck observou que Adorno produz um elo entre "o velho e o novo espírito do anticapitalismo": de um lado, a crítica à exploração do trabalho e à dominação de classe e, do outro, uma crítica ao próprio trabalho, às formas de vida no capitalismo e à mercantilização total de todas as esferas da sociedade. Cf. Fleck, Adorno, um crítico na era dourada do capitalismo.

${ }^{396} \mathrm{O}$ alvo implícito da crítica hegeliana é (segundo Hyppolite) Rousseau, o socialista utópico antes do socialismo utópico.

${ }^{397}$ Hyppolite, citando e comentando Hegel: "Cette individualité [qui est 'réelle en soi et pour soi', qui ne s'oppose pas au cours du monde, qui n'est pas l'idéal de la jouissance, de la loi du cœur ou de la vertu] ne prend plus la réalité comme une résistance à vaincre ; elle est d'emblée au milieu du monde et elle ne veut que s'exprimer elle-même." Hyppolite, Genèse et structure de la Phénoménologie de l'Esprit de Hegel, p. $286 .$.
} 
movimento histórico, era a ascensão da burguesia capitalista. Balzac pintou-a como o caminho da devastação." 398 Ou dito de forma ainda mais drástica, o espírito do mundo é o autômato da morte (a "máquina infernal"399) do século XX:

Tivesse a filosofia da história de Hegel se estendido até este tempo, então as bombas-robô de Hitler teriam encontrado o seu lugar, junto com a morte precoce de Alexandre e imagens semelhantes, entre os fatos empíricos selecionados nos quais o estado do espírito do mundo diretamente se exprime no registro simbólico. Assim como o próprio fascismo, os robôs são ao mesmo tempo lançados e sem sujeito. Como ele, associam a mais extrema perfeição técnica à completa cegueira. Como ele, provocam terror mortal e são inteiramente em vão. - "Eu vi o espírito do mundo", não a cavalo, mas com asas e sem cabeça, e isso no mesmo passo refuta a filosofia da história de Hegel. ${ }^{400}$

Reconciliar-se com o curso do mundo é entregar-se à frieza da morte, seja como defunto ou como assassino. É importante ressaltar que, ao ver as bombas-robôs de Hitler não como um acidente de percurso, mas como algo que deveria ser incorporado pela filosofia hegeliana da história, constitui-se um sentimento trágico do mundo ${ }^{401}$, inseparável de um senso de fatalidade - uma fatalidade (devidamente secularizada) de uma história naturalizada ${ }^{402}$, contra a qual o indivíduo resiste, embora sofra. No impulso romântico do indivíduo contra a máquina do mundo há um ar “conservador” (as temáticas do conservadorismo na Minima Moralia são uma constante), próprio à resistência contra o progresso (compreendido agora como "avanço rumo ao inferno"403), e que se torna evidente no apego ambivalente à experiência do indivíduo. Se em Hegel "o individualismo deve ser considerado sob suas diversas formas - desejo de gozo imediato, protestos do coração contra a ordem estabelecida, virtude revoltada contra o curso do

\footnotetext{
${ }^{398}$ Adorno, "Balzac-Lektüre" in Noten zur Literatur, GS 11, p. 154.

${ }^{399}$ MM, p. 232.

${ }^{400} \mathrm{MM}, \mathrm{p} .51$.

${ }^{401}$ Um autor que percebeu a tragicidade do pensamento de Adorno, porém em chave apologética e de reconciliação com o curso do mundo, foi Lyotard, ao dizer: "Nós temos, em relação a Adorno, a vantagem de viver em um capitalismo mais enérgico, mais cínico, menos trágico." JeanFrançois Lyotard, Des dispositifs pulsionnels, p. 121.

${ }^{402}$ No capítulo "Espírito do mundo e história natural", da Dialética Negativa, Adorno escreve: "Aquilo que outrora era indicado pelo nome mitológico do destino não é menos mítico enquanto algo desmitologizado do que uma secular 'lógica das coisas'.” DN, p. 265.

${ }^{403}$ MM, p. 231.
} 
mundo"404, Adorno dá razão, contra o mundo, a esses protestos do indivíduo ${ }^{405}$ (que entretanto já estava em vias de desaparecimento), ainda que, hegelianamente (e com a prepotência de um "socialista científico"), critique também em outros momentos essas figuras do protesto impotente (tal como as brincadeiras de barricada frente àqueles que controlam a bomba atômica ${ }^{406}$ ). Mas há, ao mesmo tempo, uma verdade nas experiências de impotência, pois "as experiências de impotência real são tudo, exceto irracionais; [...]. Somente elas permitem a esperança de uma resistência contra o sistema social [...]." ${ }^{, 407}$ Na Minima Moralia, Adorno se refere ainda ao fato de "o protesto impotente contra a frieza" suscitar a "aparência de narcisismo", mas há, segundo ele, um estreito vínculo entre impotência e humanidade: "A remoção no homem do afeto triste [trüben] e impotente está em uma relação direta com o progresso da desumanização."408 Como bem notou Alfred Schmidt, Adorno trabalha na Minima Moralia uma "unidade paradoxal entre miséria e energia crítica do indivíduo". ${ }^{409} \mathrm{Na}$ "Dedicatória" deste livro, contra o

\footnotetext{
${ }^{404}$ Hyppolite, Genèse et structure de la Phénoménologie de l'Esprit de Hegel, p. 270.

${ }^{405}$ Esse ressurgimento do "protesto" Habermas viu em Marcuse e chamou de "renascimento da subjetividade rebelde": "We all remember what Marcuse kept denouncing as the evils of our age: the blind struggle for existence, relentless competition, wasteful productivity, deceitful repression, false virility, and cynical brutality. [...] He did not hesitate to advocate, in an affirmative mood, the fulfillment of human needs, of the need for undeserved happiness, of the need for beauty, of the need for peace, calm, and privacy. [grifo meu]" Habermas, "Psychic Thermidor and the Rebirth of Rebellious Subjectivity" in Habermas and Modernity, p.67. Marcuse formula esse protesto não necessariamente como protesto do indivíduo contra o curso do mundo, mas como algo que ocorre dentro do indivíduo (clivado pelo inconsciente), a saber, como protesto pulsional: "The intellectual refusal may find support in another catalyst, the instinctual refusal among the youth in protest. It is their lives which are at stake, and if not their lives, their mental health and their capacity to function as unmutilated humans. Their protest will continue because it is a biological necessity." Marcuse, Eros and civilization, p. XXV.

${ }^{406}$ Adorno, "Notas marginais sobre teoria e práxis", p. 217.

${ }^{407}$ Adorno, "Sobre a relação entre sociologia e psicologia", p. 111.

${ }^{408}$ Adorno, Minima Moralia, GS 4, p. 295. Podemos dizer que há um humanismo latente em Adorno em suas investigações sobre a desumanização. Nos termos de Schmidt, o humanismo de Adorno está vinculado à "mutabilidade qualitativa do homem". (Alfred Schmidt, "Adorno - ein Philosoph des realen Humanismus", p. 56). Entretanto, Adorno sempre se voltou contra toda imagem positiva do humano: "O humano é a ideologia da desumanização." (Adorno, Jargon der Eigentlichkeit) Também em aula, ele diz: "Emprego aqui a expressão 'humanidade' a contragosto, pois ela pertence às expressões que enrijecem e falsificam as coisas mais importantes, pertinentes, na medida em que elas são expressas. Quando os fundadores da União Humanista me convidaram a aderir, eu respondi: 'Eu talvez estaria disposto a entrar no clube de vocês se ele se chamasse União Inumana, mas em um, que se autodenomina humanista, eu não poderia entrar." PdM 2501. Mas, ao mesmo tempo, Adorno certamente não seria tão otimista em relação ao "antihumanismo" pós-moderno, que elogia a dissolução dos limites entre homem, máquina e animal, e que abre mão da ideia de humanidade, que, para Adorno, possui ainda um teor utópico, como algo a ser realizado.

${ }^{409}$ Alfred Schmidt, “Adorno - ein Philosoph des realen Humanismus”, p. 61.
} 
"gesto fulminante com que Hegel [...] trata o indivíduo",410, Adorno escreve que "no século e meio desde a concepção hegeliana, algo da violência do protesto passou novamente para o indivíduo." 411

É de se imaginar que essa reversão adorniana (a "re-utopização" do socialismo e a recuperação do protesto moral) esteja vinculada a um veredicto sobre a época. Tanto em seu curso Sobre a doutrina da história e da liberdade quanto em sua Dialética Negativa, a discussão sobre o que ele julga ser a principal categoria moral, a saber, a liberdade, está justaposta a uma discussão sobre a história. O problema é que o vínculo entre História e Liberdade foi rompido. Carl Schmitt disse que Hegel morreu no dia 30 de janeiro de 1933. De certo modo, a filosofia adorniana é uma reflexão sobre essa tese, embora ela não seja citada, tampouco atribuída a Schmitt. Em todo caso, a revelação do século XX é que o "curso do mundo" não joga a favor. Nessa situação, a teimosia da virtude que não aceita o curso do mundo e que permanece em seu "protesto" deixa de ser uma patologia da consciência, independentemente se esse protesto é fadado ao fracasso e à derrota, como diria Hegel em defesa do mundo - o importante na atual situação, segundo Adorno, é que este momento do protesto não desapareça, que o "protesto do coração contra o mundo" não definhe, pois ele garantiria o último refúgio de uma promessa de felicidade e liberdade, a oposição em uma sociedade sem oposição. Aquele momento do conflito em que se percebe que o curso do mundo "não é tão mau" quanto aparentava, que aparece como um momento necessário da Fenomenologia do Espírito ${ }^{412}$, deixa de existir, pois o mundo é na verdade pior do que ele aparentava ser. Com essa crise do "realismo hegeliano" frente à moral, torna-se então inteligível o retorno de Adorno a Kant.

\footnotetext{
${ }^{410}$ MM, p. 11.

${ }^{411}$ MM, p. 12 (tradução alterada). Sobre Hegel e as transformações históricas da categoria de indivíduo, ver ainda Dialética Negativa, pp. 283-285.

412 "Assim, o resultado que surge dessa oposição [entre a virtude e o curso-do-mundo, FC] consiste em desembaraçar-se a consciênca como de um manto vazio, da representação de um bem em si, que não teria ainda efetividade nenhuma. Na sua luta, fez a experiência de que o curso-domundo não é tão mau quanto aparentava, já que sua efetividade é a efetividade do universal." Hegel, Fenomenologia do Espírito, p. 274. Na explicação de Hyppolite: "Le réalisme hégelien que nous retrouverons plus loin dans sa critique d'une 'vision morale du monde' s'oppose à l'idealisme sans frein de ces utopistes (Weltverbesserer). La vertu, ainsi comprise, engage une lutte vaine contre le cours du monde, et doit découvrir à la fin que ce monde n'est pas si mauvais qu'elle voulait bien le dire. Son erreur est d'opposer toujours l'idéal et le réel d'une façon telle que cet ideal ne puisse jamais s'actualiser, et en reste par conséquent toujours aux discours." Hyppolite, Genèse et structure de la Phénoménologie de l'Esprit de Hegel, p. 280.
} 


\section{A liberdade: altos e baixos da atualidade de Kant}

É justamente por a liberdade em Kant estar livre de determinação empírica é que algo da liberdade kantiana ganha atualidade, pois ela guardaria, assim, a "possibilidade" (que, com seu teor utópico, é categoria central na Dialética Negativa). Mas qual seria, afinal, a atualidade da liberdade (ou melhor, da promessa de liberdade)? Adorno tem plena consciência da historicidade da liberdade, ou seja, que ela não é algo simplesmente "humano", mas algo que remete às promessas eminentemente modernas das revoluções burguesas. A análise adorniana da noção de liberdade em Kant não desvia os olhos da patogênese da liberdade burguesa:

Desde o século XVII, a grande filosofia tinha definido a liberdade como o seu interesse mais específico; e isso sob o mandato implícito da classe burguesa para fundamentá-la de modo evidente. Não obstante, esse interesse é em si antagônico. Ele se opõe à antiga repressão e favorece a nova, que se esconde no próprio princípio racional. $\mathrm{O}$ que é procurado é uma fórmula comum para a liberdade e a repressão: a liberdade é concedida à racionalidade que a restringe e afasta da empiria na qual as pessoas não a querem ver de maneira alguma realizada. ${ }^{413}$

Neste enredamento entre repressão e liberdade (que não pode ser realizada na empiria), Adorno vê a ideia da liberação do indivíduo burguês elevada a princípio metafísico. ${ }^{414}$ Trata-se, portanto, da herança histórica de um problema. "Quem quer liberdade não deve apelar a ela ou pressupô-la, mas tratar do problema da liberdade.”, Se a filosofia moral kantiana e seu conceito de liberdade faz parte de uma herança historicamente específica - burguesa e moderna - e ideológica, pode-se dizer que a crítica adorniana da moral de Kant procede da mesma forma como a crítica imanente da ideologia. Trata-se, portanto, de exigir da ideologia aquilo que ela promete, criticá-la a partir de suas próprias normas ou, dito de modo mais preciso: contrapor a liberdade a seu próprio conceito. Por isso Adorno diz em aula: "Quando uma filosofia moral como a kantiana é criticada enquanto ideologia, então a relação da verdade a essa ideologia não

\footnotetext{
${ }^{413}$ DN, p. 181.

${ }^{414}$ PdM, pp. 106-107.

${ }^{415}$ ZLGF, p. 278
} 
seria simplesmente descartá-la, mas realizá-la." ${ }^{, 16}$ Mas o pressuposto para isso tudo é que existe, ainda, o anseio por liberdade. Tal anseio é tampouco algo perene, mas é algo que surge na experiência concreta da dominação. A atualidade da liberdade enquanto problema, segundo Adorno, é colocada pela falta de liberdade: "O contexto, no qual o conceito de liberdade se tornou novamente imprescindível para nós, é o contexto da ameaça da negação absoluta da liberdade." ${ }^{417}$ Portanto, pensar a liberdade para Adorno não significa pensar uma "condição humana" tampouco pensar algo que já existe, algo que de alguma forma determina a vida social. Pelo contrário, a liberdade é uma possibilidade (que surge como um imperativo frente à negação absoluta da liberdade na barbárie latente), ou seja, ela é um ainda-não - daí sua dimensão utópica (e por ser utópica, não deve ser menos inteligível) - embora seja uma utopia radicalmente moderna e que parecia envelhecer: "As reflexões sobre liberdade e determinismo soam arcaicas, como se viessem dos primórdios da burguesia revolucionária. Mas não se deve aceitar como uma fatalidade o fato de a liberdade envelhecer sem ser realizada; a resistência explica tal fatalidade." ${ }^{418}$ A sociedade altamente integrada do pós-guerra minava, com suas promessas de proteção no welfare state, o próprio anseio por liberdade:

A indiferença em relação à liberdade, ao seu conceito assim como à coisa mesma, é produzida pela integração da sociedade que se apresenta aos sujeitos como se fosse algo irresistível. O seu interesse em que cuidem deles paralisou o interesse por uma liberdade que eles temem não ser outra coisa senão ausência de proteção. $^{419}$

No intuito de resgatar uma promessa utópica e contra a ideia de uma liberdade que já estaria realizada na empiria da vida social (como em Hegel), um certo retorno a Kant se legitima justamente por seu conceito de liberdade guardar a possibilidade de que ele poderia se realizar, como diz Adorno em seu curso sobre $A$ doutrina da História e da Liberdade:

$\mathrm{Na}$ argumentação de Kant esconde-se o ainda-não-ser da liberdade. A liberdade é determinada por ele justamente, seria

\footnotetext{
${ }^{416}$ PM 1, 29/01/1957.

${ }^{417}$ A negação absoluta da liberdade é, no caso, a barbárie latente: realizar a liberdade coincide portanto com o imperativo de evitar a barbárie. O trecho inteiro "O contexto no qual o conceito de liberdade se tornou novamente incontornável é o da ameaçadora negação absoluta da liberdade tal qual a lembrança dos campos de concentração é inapagável para todos nós. Poderíamos então dizer: para que Auschwitz não se repita, porque simplesmente Auschwitz simplesmente não deve ocorrer, por isso a liberdade deve ser efetiva.” ZLGF, p. 278.

${ }^{418}$ DN, p. 182.

${ }^{419}$ DN, p. 182.
} 
necessário acrescentar, como uma possibilidade a ser produzida [erst herzustellende Möglichkeit]. E ninguém defendeu-se mais energicamente do que Kant da contaminação da liberdade com o ente [Seienden], ou seja, de que a liberdade mesma possa ser vista imediatamente como uma determinação da realidade. Se vocês tentarem esclarecer, interpretar nesse sentido o teor de experiência da doutrina kantiana das antinomias como um teor de experiência metafísico [metaphysischen Erfahrungsgehalt], então o sentido da doutrina da antinomia seria precisamente por isso o de abdicar da ilusão de que a liberdade já estaria realizada, para com isso salvar a possibilidade de que a liberdade alguma vez se realize. $^{420}$

Se o fato de a liberdade para Kant não ter nenhum lastro na realidade efetiva era o que motivava a crítica de Hegel, que dizia que, assim, "o bem absoluto permanece deverser sem objetividade" ${ }^{421}$, é exatamente essa possibilidade de algo que absolutamente não existe, ou seja, a realidade de algo que pode vir a ser, que motiva o retorno de Adorno a Kant. O que seria ideológico em Hegel é o enleamento da liberdade nas relações sociais, de modo que a liberdade seria considerada, assim, já realizada (a retomada de Honneth, a partir de Hegel, do conceito de "liberdade social" seria, para Adorno, igualmente apologética de uma realidade não-livre, ${ }^{422}$ em que reina a "liberdade para passar

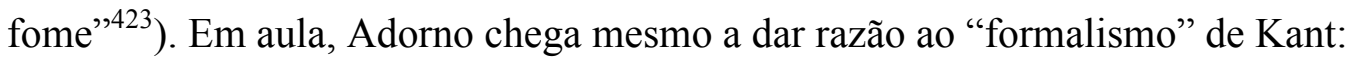

Isto leva à consequência bastante paradoxal de que a ética de Kant, aparentemente formalista, na medida em que ela, por princípio de sua universalidade, se eleva acima de toda configuração determinada do mundo que lhe defronta, seja mais radicalmente crítica frente à sociedade e suas relações existentes, assim como frente às categorias morais limitadas e finitas, que a ética baseada no conteúdo [inhaltliche] de Hegel, que em suas considerações envolve-se com a sociedade e com a crítica de figuras sociais determinadas. ${ }^{424}$

Eis a via de mão dupla da leitura adorniana da Crítica da Razão Prática de $\mathrm{Kant}^{425}$, presente sobretudo no capítulo "Liberdade" da Dialética Negativa: o caráter

\footnotetext{
${ }^{420}$ ZLGF, p. 279.

${ }^{421}$ Hegel, Vorlesungen über die Geschichte der Philosophie III, p. 372.

${ }^{422}$ Cf. Axel Honneth, Freedom's Right, op. cit.

${ }^{423}$ ZLGF, p. 277.

${ }^{424} \mathrm{PdM}$, p. 245.

${ }^{425}$ Não pretendo reconstruir aqui por inteiro a leitura de Adorno da filosofia prática de Kant, o que exigiria um espaço desproporcional em relação às outras questões que quero abordar, mas somente apontar aspectos que interessam ao argumento. O capítulo 4 da interpretação clássica de Schweppenhäuser se dedica de forma mais detida à antinomia kantiana.
} 
"abstrato" da liberdade kantiana, sua não-relação com as determinações empíricas, é tanto aquilo que motiva a crítica adorniana, quanto aquilo que, segundo Adorno, confere a Kant uma atualidade, visto que não se pode mais afirmar o vínculo entre liberdade e história como necessário. Entretanto, é certo que esta leitura de Kant passa pelas lentes materialistas de Marx e Freud, isto é, tanto pela dimensão das relações sociais como dos indivíduos concretos e suas pulsões. Ou seja, para Adorno é evidente (contra Kant) que "a sociedade é anterior ao sujeito." ${ }^{246}$ Portanto, "é somente em uma sociedade livre que os indivíduos seriam livres." ${ }^{427}$ Para além de algo simplesmente vinculado à razão (e a razão é a pedra de toque da liberdade para $\mathrm{Kant}^{428}$ ), a efetivação social da liberdade, isto é, a abolição da dominação real, permanece sendo o cerne do problema. Por outro lado, a fim de eliminar toda a heteronomia da vontade livre, Kant precisa rebaixar, com uma "dureza e rigor enormes, quase desumanos" 429 , todas as "inclinações" naturais, todas as determinações "patológicas" 430 da vontade. Tudo aquilo que no sujeito não é idêntico ao $\mathrm{Eu}$ (como toda a dimensão pulsional do inconsciente) torna-se uma barreira para a liberdade ${ }^{431}$, de modo que ela acaba por assumir um caráter sempre coercitivo em relação aos indivíduos empíricos: "Todos os conceitos que, na Crítica da razão prática, em honra da liberdade, devem preencher o abismo entre o imperativo e os homens são repressivos: lei, obrigação, respeito, dever."432

\footnotetext{
${ }^{426} \mathrm{DN}, \mathrm{pp} .113$.

${ }^{427}$ DN, pp. 221.

428 "Vocês só podem então compreender corretamente Kant e a filosofia prática kantiana sobretudo quando for claro para vocês que, na verdade, para ele liberdade e razão são a mesma coisa." PdM, p. 107.

${ }^{429}$ PdM, p. 107.

430 "Patológico" é aqui compreendido como vinculação a um objeto da vontade. Sobre a apatia da vontade: "[...] Sade, tal como Kant, eleva a apatia a pressuposto indispensável da virtude. Os carrascos de Sade executam de maneira apática a Lei, sem deixar-se guiar por prazeres sensíveis. Como se fosse sempre questão de negar a efervescência do prazer sensível ligado ao eu, a fím de dar lugar ao calor do poder demonstrativo da Lei. A apatia (assim como a crítica à compaixão) aparece como negação radical do desejo ainda ligado às escolhas patológicas de objeto, negação daquilo que Adorno chamará de afinidade mimética com o objeto. Deleuze fala com propriedade da apatia sadeana como: 'o prazer de negar a natureza em mim e fora de mim, e de negar o próprio Eu [empírico]'." Safatle, Sobre a gênese psicológica do transcendental: Adorno entre Freud e Kant, p. 71.

${ }^{431}$ Se com a descoberta do inconsciente pela psicanálise, o sujeito revela-se como um sujeito clivado, a moral kantiana pressupõe, pelo contrário, uma unidade psicológica de um Eu íntegro, como diz o próprio Adorno em aula: "Todo o rigorismo moral em Kant (e também em outros pensadores) tem sempre essa nuance: tu não deves dissolver, tu deves permanecer uma unidade, seguir teu caminho e não te perder." PM1, 1511.

${ }^{432}$ DN, p. 196.
} 
Tais aspectos tocam no problema central da moral kantiana, a saber, a relação entre liberdade e lei, que era já o objeto da terceira antinomia da Crítica da Razão Pura. O objetivo ali é investigar se há uma legalidade própria à liberdade, ou se, pelo contrário, não existe liberdade e todo nexo causal segue as leis dadas pela natureza. A antinomia kantiana, que, enquanto tal, permanece antinômica, isto é, sem solução, atingindo aí um dos limites da razão visados pela crítica (que para Kant não é outra coisa senão pôr limites ${ }^{433}$ ), estrutura-se da seguinte forma: segundo a tese, "a causalidade segundo leis da natureza não é a única da qual possam ser derivados os fenômenos do mundo em conjunto. Para explicá-los é necessário admitir ainda uma causalidade mediante liberdade." Segundo a antítese, "não há liberdade alguma, mas tudo no mundo acontece meramente segundo leis da natureza." ${ }^{434}$ Como é possível, racionalmente, demonstrar tanto a tese como a antítese, encontra-se aí um limite do conhecimento teórico (por isso o entendimento incorre em antinomias), pois a liberdade não se encontra no âmbito dos fenômenos, e sim na coisa em si, no númeno. A liberdade não pode ser compreendida segundo as leis da natureza e, como Kant afirma, "onde cessa a determinação segundo leis da natureza também cessa toda explicação." ${ }^{435}$ Para a razão prática, a liberdade está no âmbito do dever ser e seria capaz de imputar valores à ação, mas ainda assim ela não tem uma realidade efetiva e nenhuma garantia de existência no mundo sensível. Ela se realiza enquanto autonomia do sujeito, enquanto universalização da lei que se põe a si. Retorna aqui o problema da relação entre liberdade e lei (no caso kantiano, uma lei da razão, portanto fornecida pelo próprio sujeito - daí o sentido da autonomia). Segundo Adorno, na identificação da liberdade com a lei e com a necessidade, intensificada no idealismo pós-kantiano, anula-se a possibilidade de liberdade (que deveria ser, por sua vez, a quebra das relações causais, fonte de toda espontaneidade verdadeira):

$\mathrm{Na}$ construção de toda a antitética, liberdade e causalidade entrecruzam-se. Uma vez que a liberdade equivale em Kant a uma ação segundo a razão, ela também é conforme à lei: mesmo as ações livres "seguem regras". A partir daí surgiu a hipoteca insuportável da filosofia pós-kantiana, o fato de não haver nenhuma liberdade sem lei; ela não consistiria senão na identificação com essa lei. Para além do idealismo alemão e com uma consequência política imprevisível, foi Engels que continuou

\footnotetext{
${ }^{433} \mathrm{Na}$ Dialética Negativa, Adorno diz que "o sistema kantiano é um sistema de sinais de 'Pare!'." DN, p 321.

${ }^{434}$ Immanuel Kant, Crítica da Razão Pura, pp. 294-296 (B472-474).

${ }^{435}$ Immanuel Kant, Fundamentação da metafísica dos costumes, p. 295.
} 
acolhendo essa herança: essa é a origem teórica da falsa reconciliação. $^{436}$

A "falsa reconciliação" é justamente essa falsa identificação da liberdade com a necessidade. Em Kant, essa identificação entre liberdade e obediência à lei, compreendida historicamente, é, segundo Adorno, a expressão de um temor ante a anarquia próprio da consciência burguesa: "Uma causalidade derivada da liberdade corrompe a liberdade e a transforma em obediência. Kant, tal como os idealistas depois dele, não pode suportar a liberdade sem coerção; sua concepção não-velada já prepara para ele esse temor ante a anarquia que inspira mais tarde a consciência burguesa à liquidação de sua própria liberdade." ${ }^{437}$ A noção adorniana de liberdade, enquanto uma liberdade absoluta, poderia parecer assim portanto demasiado indeterminada e "abstrata". Porém, ela ganha em determinidade e torna-se concreta enquanto negação da não-liberdade: "De acordo com a figura concreta da não-liberdade, a liberdade só pode ser apreendida em uma negação determinada. Positivamente, ela torna-se um como-se." ${ }^{438}$ Podemos dizer então que a liberdade torna-se inteligível no contexto de uma ética da resistência.

\section{Resistência (Sartre: pro e contra)}

Não seria um exagero comparar essa concepção de liberdade, que se torna concreta na oposição à não-liberdade, com a ética sartriana, que, apesar das diferenças, também foi forjada na experiência da resistência ao fascismo ${ }^{439}$ e partilha com Adorno ainda um profundo anti-colaboracionismo. ${ }^{440}$ A resistência é uma oposição ao curso do mundo, uma não aceitação dos fatos: "la résistance, qui a fini par triompher, montre que le rôle de l'homme est de savoir dire non aux faits même lorsqu'il semble qu'on doive s’y soumettre." 441 De forma semelhante a Sartre, Adorno vislumbra a concretude da liberdade na experiência de oposição à dominação:

\footnotetext{
${ }^{436}$ DN, p. 209.

${ }^{437}$ DN, p. 196.

${ }^{438}$ DN, p. 195.

${ }^{439}$ Também Günther Anders, como nota Manfred Bissinger, "importa" um modelo da resistência francesa para a Alemanha. Cf. prefácio a Anders, Gewalt - Ja oder nein, p. 8

${ }^{440}$ Podemos definir o colaboracionismo, a partir de Sartre, como uma espécie de identificação entre a moral e os fatos (daí o caráter profundamente "anti-realista" da resistência): "Par sa docilité aux faits - ou plutôt à ce fait unique : la défaite française - le collaborateur 'réaliste' fait une morale renversée : au lieu de juger le fait à la lumière du droit, il fonde le droit sur le fait; sa métaphysique implicite, identifie l'être et le devoir-être. Tout ce qui est est bien ; ce qui est bien c'est ce qui est." Sartre, Qu'est-ce qu'un collaborateur? In: Situations III, p. 66.

${ }^{441}$ Idem, p. 61.
} 
A liberdade torna-se concreta nas figuras alternantes da repressão: na resistência a ela. Há tanta liberdade da vontade quanto há a vontade de os homens se libertarem. A própria liberdade, contudo, está tão enredada com a não-liberdade que ela não é meramente inibida por esta, mas a contém como condição de seu próprio conceito. ${ }^{442}$

"Nunca fomos tão livres como durante a ocupação alemã."443 Assim começa Sartre seu ensaio A república do silêncio, escrito no final da guerra. A liberdade torna-se aqui idêntica à experiência da resistência à situação de não-liberdade. Porém, no caso de Sartre (essa é a crítica de Adorno), a liberdade torna-se tão dependente da decisão diante de uma situação heterônoma ${ }^{444}$, que tal situação seria, ao fim e ao cabo, hipostasiada. Um dos momentos em que Adorno se posiciona de forma clara em relação a essa concepção é em uma nota de rodapé da Dialética Negativa:

Os experimentos de pensamento kantianos não são desprovidos de analogia com a ética existencialista. Kant, que sabia muito bem que a boa vontade tem por terreno a continuidade de uma vida e não o ato isolado, aguça no experimento - para que esse demonstre o que deve - a boa vontade na decisão entre duas alternativas. Quase não há mais essa continuidade; é por isso que, em uma espécie de regressão ao século XVIII, Sartre se restringe unicamente à decisão. Todavia, na medida em que a autonomia deve ser demonstrada junto à situação alternativa, ela é heterônoma em relação a todo conteúdo. Kant viu-se diante da necessidade de oferecer um déspota em um de seus exemplos referentes às situações de decisão; de maneira análoga, os exemplos sartrianos são frequentemente oriundos do fascismo; em verdade, como denúncia do fascismo, não como condition humaine. Livre só seria quem não precisasse se curvar a nenhuma alternativa, e no existir há um vestígio da liberdade de se recusar

\footnotetext{
${ }^{442}$ DN, p. 222.

${ }^{443}$ Jean-Paul Sartre, "La République du Silence", Situations III, p. 11. Lembremos que o nível de politização dos intelectuais durante a resistência ao fascismo na França foi algo inédito e possuía uma dimensão que muitos desses intelectuais gostariam de preservar no período do pós-guerra, como aparece por exemplo não só nesse texto de Sartre, mas também em um texto de MerleauPonty publicado em outubro de 1945 em Les Temps modernes: "Dans la résistance, l'union était facile parce que les rapports étaient presque toujours des rapports d'homme à homme. [...] On a $\mathrm{pu}$ voir dans la résistance les intellectuels les moins enclins à la politique. L'expérience de la résistance a été pour eux une expérience unique et ils voulaient en garder l'esprit dans la nouvelle politique française, parce qu'elle échappait enfin au fameux dilemme de l'être et du faire que est celui de tous les intellectuels devant l'action." M. Merleau-Ponty, "La guerre a eu lieu" in Oeuvres. Paris: Gallimard, 2010, p. 118.

${ }^{444}$ Já em seu primeiro curso sobre filosofia moral, Adorno dizia: "In diesem Entscheiden-müssen steckt ein Triumph der Welt. Gerade da, wo die Existentialphilosophie den Begriff der Freiheit am reinsten zu haben meint, hat sie ihn am gründlichsten verraten.” PM 1, 04/12/1956.
} 
a todas elas. Liberdade significa crítica e transformação das situações, não a sua confirmação por meio da decisão em meio à sua estrutura de constrangimento. Quando Brecht fez seguir à sua primeira peça, coletivista e didática Aquele que diz sim, depois de uma discussão com alunos, Aquele que diz não, o dissidente contribuiu, contra o seu credo oficial, para a admissão dessa ideia. $^{445}$

Essa nota de rodapé reproduz em parte argumentos de um texto que Marcuse publicou sobre O ser e o nada em 1948 (e que Adorno leu com entusiasmo na época de sua publicação ${ }^{446}$ ). Marcuse já criticava ali a concepção de liberdade como algo da essência humana e, portanto, algo que não se perde mesmo diante da absoluta heteronomia: "The essencial freedom of man, as Sartre sees it, remains the same before, during, and after the totalitarian enslavement of man. For freedom is the very structure of human being and cannot be annihilated even by the most adverse conditions: man is free even in the hands of the executioner." 447 A liberdade torna-se compatível com a dominação, que por sua vez jamais altera o estado de liberdade: "Sartre [...] sets out to prove that even in a situation of extreme determinateness, man is and remains absolutely free." ${ }^{448}$ A ideia de escolha como liberdade era já também criticada por Marcuse, visto que ela não questiona a situação de não liberdade que impõe a escolha: "The free choice between death and enslavement is neither freedom nor choice, because both alternatives destroy the "realité humaine' which is supposed to be freedom." 449 O "reino da liberdade", isto é, a liberdade socialmente efetivada, é uma ilusão, por isso, a liberdade significa então aprender a frustração em um mundo não-livre: “[...] precisely because frustration is permanent and inevitable (since it is the ontological characteristic of the human being), it is also the very foundation and condition of human freedom."

A noção sartriana de liberdade permaneceria, assim, algo próprio somente do sujeito, ou algo que o sujeito conquista, independente da transformação do mundo e da efetivação da liberdade nas relações sociais. Comentando o texto de Marcuse, Adorno

\footnotetext{
${ }^{445}$ DN, p. 191.

${ }^{446}$ Como se lê em Carta de Adorno a Marcuse, 25/06/1948, TWAA.

${ }^{447}$ H. Marcuse, "Existentialism: remarks on Jean-Paul Sartre's L'Être et le Néant". Philosophy and Phenomenological Research, Vol. VIII, No. 3, 1948, p. 311.

${ }^{448}$ Ibid., p. 320.

${ }^{449}$ Ibid., p. 322.

${ }^{450}$ Ibid., p. 316. Em carta a Marcuse, Adorno escreve: "Especialmente felizes são as formulações centrais sobre a ideia atrofiada de liberdade [...]. Muito boa a parte sobre a ontologização da decepção histórica." Carta de Adorno a Marcuse, 25/06/1948, TWAA.
} 
escreve em carta: "Você tem toda razão, o argumento sartriano lembra o do pai judeu que explica a seu filho revolucionário que primeiro deve-se mudar os homens antes de mudar a sociedade. ${ }^{, 451}$ Portanto, apesar de existir, para Adorno, uma liberdade possível como resistência, ou ainda, como negação determinada da não-liberdade, a situação de nãoliberdade não pode ser pensada como permanente e o horizonte deve ser a efetivação da liberdade real no mundo, que o sujeito não mais sentiria como resistência. A crítica que Adorno endereça a Kant é da mesma natureza, na medida em que a ética kantiana, enquanto uma "ética de convicção", ao centrar-se puramente na realidade subjetiva, permanece indiferente em relação à realidade social. ${ }^{452}$ Aqui retorna em Adorno a crítica hegeliana da "convicção", que rejeita o mundo, mas deixa-o inalterado:

A convicção é uma determinação que é meramente para si, que encontra satisfação em si mesma, que permanece sem consequência para a organização da sociedade. De certo modo, ela também é relativamente pouco ameaçada pela sociedade. Seu pathos é criticar uma sociedade na qual tudo tornou-se meio e nada mais permanece fim. ${ }^{453}$

Nota-se que o procedimento adorniano é constantemente jogar Kant contra Hegel, e vice-versa. Ao mesmo tempo em que Adorno vê um momento crítico na ética kantiana justamente ao não se envolver com conteúdos empíricos e determinados, resguardando, assim, o "ainda-não" da liberdade, a ideia de que a moral para Adorno seria "intransitiva", sem relação a objetos ou à empiria, é certamente equivocada. Se Hegel criticava o "dever puro, indiferente a todo o conteúdo determinado",454 o novo imperativo categórico adorniano não poderia ser mais determinado, mais singular, diversamente do de Kant que tinha um caráter estritamente formal ${ }^{455}$ (a saber, a forma da universalização das normas

\footnotetext{
${ }^{451}$ Carta de Adorno a Marcuse, 25/06/1948, TWAA.

${ }^{452}$ Adorno fala ainda de uma "não-inclusão da realidade", que inverte o sentido da ação moral: "A não-inclusão da realidade inverte as consequências, na qual a vontade pura insiste." $P d M$, p. 242.

${ }^{453}$ PdM, pp. 230-231.

${ }^{454}$ Hegel, Fenomenologia do Espírito, p. 416.

${ }^{455}$ Apesar disso, Adorno, em certos momentos, não só dá razão ao formalismo kantiano (contra a "ética material de valores" de um Max Scheler), como ele reconhece nesse formalismo um conteúdo bem específico, a saber, a igualdade: "O comportamento moral, evidentemente mais concreto do que um comportamento meramente teórico, torna-se mais formal do que este em consequência da doutrina de que a razão prática é independente de tudo 'aquilo que lhe é estrangeiro': de todo objeto. Com certeza, o formalismo da ética kantiana não é apenas essa coisa condenável que, desde Scheler, vem sendo estigmatizada pela filosofia escolar reacionária alemã. Apesar de não fornecer nenhuma casuística positiva daquilo que se precisaria fazer, ele interdita humanamente o abuso de diferenças qualitativas de conteúdo em favor do privilégio e da ideologia. Ele estipula a norma de direito universal; nessa medida, apesar de e por causa mesmo de sua abstração, continua vivendo um certo conteúdo, a ideia de igualdade. A crítica alemã de
} 
que o sujeito põe para si). O novo imperativo categórico foi imposto por uma contingência histórica: "Em seu Estado de não-liberdade, Hitler impôs aos homens um novo imperativo categórico: instaurai o vosso pensamento e a vossa ação de tal modo que Auschwitz não se repita, de tal modo que nada desse gênero aconteça." 456 Ao contrário do "dever em geral”457, o dever posto pelo imperativo categórico adorniano extrai seu teor moral de uma situação: neste aspecto, esse dever se realiza como uma moral situada. Ou antes, ele é uma reação ao inaceitável - mais especificamente, àquilo que é horrível.

\section{Justificar seria obsceno: sobre o horror}

Ficar sem palavras no horror é uma vivência originária.

Walter Benjamin

Nesse mesmo sentimento do intolerável, Marx escreveu seu imperativo categórico na introdução à Crítica da filosofia do direito de Hegel: "A crítica da religião termina com a doutrina de que o homem é a essência suprema [höchste Wesen] para o homem, ou seja, com o imperativo categórico de derrubar todas as relações nas quais o homem é um ser humilhado, escravizado, abandonado, desprezível." ${ }^{, 458}$ Em ambos os casos, tanto no imperativo categórico de Marx como no de Adorno, prescinde-se de justificação o imperativo que parte do caráter abominável e inaceitável do sofrimento e da dominação. Para Adorno, a exigência de fundamentação ou justificação de um imperativo moral escapa do âmbito da moral. De forma semelhante, também Kant, ao fundamentar o imperativo categórico, chegou a um "fato da razão" não fundamentável. No caso de Adorno, essa aversão à fundamentação da moral liga-se a um motivo materialista em seu vínculo com a experiência de sofrimento corporal:

Esse imperativo é tão refratário à sua fundamentação quanto outrora o dado do imperativo kantiano. Tratá-lo discursivamente seria um sacrilégio: é possível sentir nele corporalmente o momento de seu surgimento junto à moralidade. Corporalmente

que o formalismo kantiano seria por demais racionalista conheceu a sua cor sangrenta na prática fascista que tornava dependente da aparência cega, do pertencimento ou não-pertencimento a uma raça designada, quem deveria ser assassinado.” DN, p. 199.

${ }^{456}$ DN, p. 302.

457 "[...] na ação efetiva a consciência se comporta como este $\mathrm{Si}$, como uma consciência completamente singular: está dirigida à efetividade enquanto tal, e tem-na por fim, pois quer implementá-la. O dever em geral recai assim fora dela, em uma outra essência, que é a consciência e o sagrado legislador do dever puro." Hegel, Fenomenologia do Espírito, p. 417.

${ }^{458}$ MEW 1, p. 385. 
porque ele é o horror que surgiu praticamente ante a dor física insuportável à qual os indivíduos são expostos mesmo depois que a individualidade, enquanto forma de reflexão espiritual, se prepara para desaparecer. A moral só sobrevive em um motivo materialista sem disfarces. ${ }^{459}$

Se a categoria de sofrimento pode ter diversas nuances, abordagens e definições, Adorno com frequência se refere àquilo que prescinde de maiores explicações: dor sentida no corpo violentado. Afinal, mesmo o sofrimento "espiritual" (o medo, a angústia e o desespero) encontrará sua verdade na experiência corporal, eis seu "motivo materialista sem disfarces" ${ }^{\$ 60}$. Por isso, a dor, enquanto algo vinculado aos baixos corporais e à crueza da realidade, aparece na reflexão filosófica como o grosseiro, desprovido de sofisticação, complexidade, delicadeza, profundidade, interioridade - noções que, frente à dimensão bruta da dor real, tornam-se ornamentos mistificadores. Não é por outro motivo que Adorno escreve que "a única delicadeza se encontraria no mais grosseiro [...]": isto é, em nome da delicadeza enquanto possibilidade, faz-se necessário o recurso ao grosseiro e brutal.

Embora não se encontre, salvo engano, nenhuma distinção na obra adorniana entre sofrimento socialmente produzido e sofrimento em geral (pois, a rigor, toda experiência é socialmente mediada e portanto não seria possível isolá-la do todo, e mesmo os sofrimentos impostos pela natureza não se separariam daqueles impostos pela sociedade), é difícil imaginar que, nessa relação entre moral e "dor física insuportável", Adorno tenha em mente a dor de uma fratura óssea produzida por um acidente em um jogo de futebol entre amigos ou algo semelhante; mas possivelmente a fratura do mesmo osso causada durante uma sessão de tortura da SS (o que contradiz, portanto, um materialismo positivista da dor física, que a tomaria isoladamente). Afinal, como disse recentemente um militar do DOI-Codi sobre sua atuação na ditadura no Brasil, "tortura é uma palavra

\footnotetext{
${ }^{459}$ DN, p. 302-303.

${ }^{460}$ Também Freud assume esse motivo materialista ao dizer que "todo sofrimento é apenas sensação, existe somente na medida em que o sentimos, e nós o sentimos em virtude de certos arranjos de nosso organismo." Freud, O Mal-Estar na Civilização, p. 21. Schopenhauer, ao contrário, não calca o sofrimento na experiência corporal, mas pelo contrário, calca a experiência corporal no sofrimento, aqui sim um ente metafísico (que está ligado à não menos metafísica vontade): "[...] querer intenso e veemente sempre traz consigo sofrimento intenso e veemente. Pois todo sofrimento nada é senão querer insatisfeito e contrariado: até mesmo a dor do corpo, quando este é ferido ou destruído, é enquanto tal unicamente possível em função de o corpo nada ser senão a vontade mesma tornada objeto." Schopenhauer, $O$ mundo como vontade $e$ representação, p. 422.
} 
muito pesada, mas houve sofrimento físico". ${ }^{461}$ Para além dos campos de concentração, a tortura é uma das únicas situações concretas de sofrimento mencionadas por Adorno quando ele se refere ao aspecto irracional do "impulso imanente ao comportamento moral", de modo que, como representativo daquilo que pode ser pior do que a morte, a tortura, no limite, assume para Adorno uma dimensão paradigmática.

As questões morais são colocadas de maneira vinculadora [...] em sentenças tais como: não se deve torturar; não deve haver campos de concentração [...]. Essas sentenças são verdadeiras enquanto impulsos, logo que se anuncia que em algum lugar se faz uso da tortura. Elas não devem ser racionalizadas; enquanto princípios abstratos, elas cairiam imediatamente na má infinitude de sua dedução e de sua validade. [...] O impulso, o temor físico nu e cru e o sentimento de solidariedade com os corpos torturáveis, para usar uma expressão de Brecht, o impulso que é imanente ao comportamento moral seria negado por medo da aspiração à racionalização intransigente; o mais urgente se tornaria uma vez mais contemplativo, escárnio em relação à própria urgência. ${ }^{462}$

Esse caráter irracionalizável do impulso moral contra a tortura (que significa horrorizar-se diante do horror) liga-se ao caráter irracionalizável, ou melhor, indizível da própria dor na tortura, daquilo que não se permite verbalizar e que é avesso a toda discursividade. Nos termos de Walter Benjamin, "ficar sem palavras no horror é uma vivência originária" ${ }^{463}$. Não é por acaso que o horror é também, tradicionalmente, uma categoria estética. Nesse caso, "estético" abrigaria menos o sentido de algo "artístico", do âmbito da criação, visto que se trata não de obras de arte, mas do próprio mundo, e mais o sentido kantiano, relativo à sensibilidade - podemos dizer que, objetivamente, só existe horror se há um sujeito que é capaz de horrorizar-se. Ao mesmo tempo, a dessensibilização, a adaptação e a aceitação dos indivíduos perante a situação horrível, diante da qual eles não mais sentem medo e com a qual eles colaboram, é parte constituinte do cenário de terror. De todo modo, o sofrimento e o horror apontam para os limites da linguagem discursiva. Em um célebre ensaio sobre a tortura, Jean Améry, refletindo sobre sua própria experiência no campo de concentração, abdica da comunicação ao falar sobre a dor: “A dor era o que era, não há nada a dizer além disso.

\footnotetext{
${ }^{461}$ Declaração de Pedro Ivo Moézia em "Tiroteios e interrogatórios: a ditadura na visão de um militar do DOI-Codi", Uol, 13 de dezembro de 2018.

${ }^{462} \mathrm{DN}$, p. 238.

463 "Die Sprachlosigkeit im Grauen ein Urerlebnis." Walter Benjamin, "Über das Grauen II", Gesammelte Schriften VI, p. 77.
} 
As características das sensações são incomparáveis e indescritíveis. Elas marcam os limites da nossa capacidade de comunicação verbal. Quem desejasse partilhar essa dor com outro seria obrigado a infligí-la, tornando-se um torturador."

Para além do caráter extremo disso que é literalmente o inferno na Terra, podemos talvez pensar que a crítica da tortura fornece um modelo para a crítica do sofrimento social (entenda-se: socialmente produzido). Todo sofrimento social - a jornada exaustiva de trabalho, a angústia do desempregado que o leva ao suicídio, o tapa que se leva do policial em um enquadro ${ }^{465}$ - pode ser pensado como níveis da tortura (física ou psicológica), distendida no tempo e de intensidade variada, ou diferentes momentos de uma situação infernal (não são raras as passagens em que Adorno se vale da referência bíblica ao inferno para caracterizar experiências terrenas). Não que essas diversas experiências de dor ou sofrimento sejam comparáveis ou equiparáveis à tortura, algo cuja dimensão extrapola qualquer termo de comparação, de modo que, na comparação, corremos o risco (imoral, decerto) de fazer injustiça às vítimas da tortura propriamente dita. Mas visto que a tortura é a expressão mais extrema e depurada de sofrimento humano infligido por um outro, em que a dor aparece mais colada em uma relação (no caso, entre torturador e torturado), ela torna-se protótipo de todo sofrimento social, de todo sofrimento produzido em um contexto (seja o algoz o torturador, que porta a culpa individual pelo sofrimento infligido, seja o "contexto geral de culpa", que na impessoalidade da dominação capitalista abstrata não é menos culpado) - um contexto no qual se expressa a racionalidade irracional da sociedade. Assim, a tortura torna-se protótipo de todo sofrimento que poderia - e deveria - não existir. Dito isto, há uma convergência entre o imperativo de abolir a tortura e o de abolir todo sofrimento socialmente produzido. E como no segundo caso o algoz é a sociedade, tal imperativo conflui com o imperativo categórico marxiano, citado acima, de transformação das relações sociais.

\footnotetext{
${ }^{464}$ Jean Améry, Para além do crime e castigo: tentativa de superação, p. 68.

${ }^{465}$ Aliás, como apontava o próprio Améry, há uma linha de continuidade entre "a primeira bofetada" do policial e a tortura: "A primeira bofetada torna o preso consciente do seu desamparo e já contém em germe tudo o que ele sofrerá mais tarde. A tortura e a morte em uma cela, fatos que podíamos antever sem que esse conhecimento se tingisse de cores vivas, torna-se realidade e mesmo certeza - com a primeira bofetada. Podem me bater no rosto, percebe a vítima em mudo espanto e, finalmente, em certeza silenciosa: farão comigo o que quiserem.” Ibid., p. 60.
} 
Ainda sobre a justificação: o fato de Adorno julgar que faz parte da moral não justificar frases como "não se deve torturar" ou "que Auschwitz não se repita" não significa que elas sejam frases irracionais e injustificáveis. Pelo contrário: tais frases são muito bem justificáveis discursivamente, mas a necessidade de justificá-las discursivamente e racionalmente já não faz parte da moral. Como diz Schweppenhäuser: "Uma fundamentação discursiva seria possível; mas, frente à clara indizibilidade do sofrimento produzido pelo homem, seria presunçoso exigir que a demanda de abolição desse sofrimento devesse ser legitimada somente pelo meio discursivo."466 Günther Anders procede de forma semelhante em relação ao pressuposto de que se deve ser contra o fim da humanidade: não interessa à moral justificar ou fundamentar tais posições. Diz ele: “A questão sobre se deve haver humanidade e não, pelo contrário, nenhuma, faz sentido no máximo no âmbito da razão teórica (caso seja possível respondê-la), para a 'razão prática' ela é desinteressante." 467

O horror inaceitável (que é a própria realidade "nua e crua") torna-se uma categoria moral, e a sensibilidade para tal, uma capacidade a ser desenvolvida, pressuposto tanto para a crítica quanto para a ação moral. Se há uma ideia de formação para a moral em Adorno, ela passa pela formação da sensiblilidade e da inteligência que possibilita ao indivíduo horrorizar-se diante do horror e não aceitá-lo. E se ela assemelhase a uma espécie de educação para a resistência, é porque a experiência concreta da resistência fornece um paradigma moral. Objetivamente, o horror (a barbárie, as trevas, o inferno) é o segundo nome do fascismo, tanto em sua dimensão historicamente específica (aquilo que podemos chamar de "fascismo histórico" dos anos 1930 e 1940), quanto aquilo que permanece como latência da sociedade capitalista moderna, como sua

\footnotetext{
${ }^{466}$ Schweppenhäuser, Ethik nach Auschwitz, p. 216. Ou ainda: "Dessa consideração segue que a fundamentação [Begründen] teórica, sozinha, não basta para fundar [fundieren] o novo imperativo categórico de Adorno, mas não se segue daí que ele seria por princípio incompatível com um fundamentação teórica, ou mesmo enfraquecido ou falsificado por meio de uma tal fundamentação." Ibid.

${ }^{467}$ Anders, Die Antiquiertheit des Menschen II, p. 390. Essa proximidade entre Adorno e Anders, no que concerne a não fundamentação teórica da moral, não escapou a Schweppenhäuser: "Aliás, Günther Anders fez isso de forma semelhante. A diferença em relação ao motivo de Adorno é certamente o recurso manifesto ao valor inabdicável da conservação do mundo e do gênero humano frente a sua ameaçadora auto-aniquilação. Também para Anders a necessidade moral de impedir a aniquilação dispensa de uma fundamentação [Begründbarkeit] moral-filosófica." Schweppenhäuser, Ethik nach Auschwitz, p. 215. Como diz o próprio Anders: "A exigência [Erforderlichkeit] moral de Mundo e Homem é ela mesma não mais moralmente fundamentável." Anders, Die Antiquiertheit des Menschen I, p. 323.
} 
pulsão de morte em sua dimensão propriamente exterminista e violenta, e que se manifesta de diversas formas. Não é por acaso que, em uma das poucas vezes em que Adorno cita uma ação moral concreta (nesse caso, em uma das aulas de seu curso sobre filosofia moral), ela é uma ação de resistência ao fascismo (em que aparece novamente essa dimensão irracional de reação ao insuportável, que resulta desse sentimento de horror diante do horror):

Talvez eu possa explicar-lhes isto com uma experiência, uma experiência bastante simples, que eu tive nos primeiros meses depois que voltei da emigração para a Alemanha, isso já faz quase 14 anos. Eu tive a oportunidade então de conhecer um dos poucos homens decisivos do 20 de julho $^{468}$, eu conversei com ele e lhe perguntei: 'o senhor certamente sabia que a chance de êxito da conspiração era mínima, e o senhor deveria também saber que, caso fosse pego, esperaria algo muito mais terrível que a morte algo inimaginavelmente terrível. Como the foi possível agir mesmo assim?' E esse homem - os senhores certamente conhecem seu nome, não quero citá-lo agora-me respondeu: 'Há situações que são tão insuportáveis que simplesmente não se pode continuar [weiter mitmachen], não importa o que aconteça e não importa o que possa acontecer a si na tentativa de mudá-la.' Ele me disse isso sem nenhum pathos, e eu gostaria de dizer, também sem nenhuma ambição teórica, simplesmente assim. Com isso ele queria explicar o que o moveu ao aparentemente absurdo daquela ação do 20 de julho. Creio que precisamente esse momento da resistência - de que pode haver algo tão insuportável que se deve tentar transformá-lo, não importa quais consequências possa haver para si e sob circunstâncias que teoricamente se poderia prever que também possa haver consequências para outros - creio que é exatamente esse o ponto em que a irracionalidade, ou permitam-me dizer, o momento irracional da ação moral deve ser buscado, o ponto onde ele se encontra. ${ }^{469}$

\footnotetext{
${ }^{468}$ Trata-se do atentado (fracassado) de 20 de julho de 1944, que visava assassinar Hitler e derrubar seu governo (observação nossa).

${ }^{469}$ PdM, p. 19. Nesse mesmo contexto do momento irracional da ação moral, há a questão sobre a dimensão moral da violência. Benjamin havia escrito : "O ato de matar o criminoso pode ser moral [sittlich] - jamais a legitimação desse ato." Benjamin, Rua de mão única, p. 61. Adorno retoma essa afirmação (cujo cerne é uma contradição) ao tratar da justiça em relação aos algozes de Auschwitz: "É nesse ponto que se concentra o Estado mais recente da dialética moral: a liberação [dos torturadores] seria uma injustiça nua e crua, a justa expiação seria contaminada pelo princípio da violência assassina, sendo que a humanidade não seria outra coisa senão uma resistência a essa violência. A afirmação de Benjamin de que a aplicação da pena de morte pode ser moral, mas nunca a sua legitimação, profetiza essa dialética. Se tivéssemos fuzilado sumariamente os encarregados da tortura juntamente com os seus mandantes e os seus protetores extremamente perigosos, isso teria sido mais moral do que abrir um processo para alguns deles. $\mathrm{O}$ fato de eles terem conseguido fugir e se manter escondidos por vinte anos altera
} 
A ação moral não se baseia em princípios ou fundamentos seguros, perenes e transponíveis para qualquer contexto: ela é, pelo contrário, uma resposta contingente a uma situação concreta, sentida como inaceitável. De forma análoga, a ideia de uma "filosofia moral" não é, tampouco, uma fundamentação da ação moral e nem poderia assumir um caráter de sistema: ela é, também, uma reflexão sobre uma situação concreta e inaceitável. Por isso é absurdo do ponto de vista moral lidar com "hipóteses", tão frequente nos problemas de filosofia "moral" de vertente analítica que em geral são reduzidos a cálculo e gestão da barbárie, tais como: você está dirigindo um carro a $100 \mathrm{~km} / \mathrm{h}$ e uma criança aparece na pista, se você desviar, você irá atropelar um idoso na calçada - quem você deve matar? ${ }^{470}$ Não é muito difícil ver como esse campo aplicado

qualitativamente a justiça que deixou outrora de ser feita em relação a eles. No momento em que se mobiliza uma máquina judicial com o seu código de instrução penal, com as batas e os defensores plenos de compreensão, a justiça, de todo modo incapaz de aplicar qualquer sanção que fizesse jus ao crime cometido, é já falsificada, comprometida pelo mesmo princípio segundo o qual os assassinos um dia agiram." (DN, 238-9). Tal discussão sobre a violência nos levaria inevitavelmente a uma discussão sobre o direito: para Adorno, fuzilar os algozes de Auschwitz não seria punir os algozes de Auschwitz (como todos frankfurtianos na época, eles certamente leram o estudo Punição e estrutura social, de Rusche e Kirchheimer, que é retomado décadas mais tarde por Foucault em Vigiar e punir), e sim só faria sentido (só seria moral) como violência revolucionária. É precisamente isso que, segundo Adorno, fundamenta a aporia da impossibilidade de se fazer justiça frente aos torturadores. "O fundamento histórico da aporia", diz Adorno, "é o fato de, na Alemanha, a revolução contra os fascistas ter fracassado ou, muito mais, o fato de não ter havido em 1944 nenhum movimento revolucionário de massas." (Ibid) Ou seja, se houve uma justiça a ser realizada, ela não estava (e nem está) no âmbito da identidade fetichista entre crime e pena, e sim na possibilidade histórica concreta da emancipação. A crítica de Adorno ao direito aparece não somente nesse trecho sobre justiça. Mais adiante, ele diz: "O direito é o fenômeno primordial de uma racionalidade irracional. Nele, o princípio formal da equivalência transforma-se em norma e insere todos os homens sob o mesmo molde. Uma tal igualdade, na qual perecem as diferenças, favorece sub-repticiamente a desigualdade; um mito que sobrevive em meio a uma humanidade que só aparentemente é desmitologizada." (DN, p. 257) A crítica da lógica identitária, tema adorniano por excelência, aparece como crítica da forma jurídica. Isso é algo que aproxima Adorno de uma certa crítica marxista do direito tal como empreendida por Pachukanis, o jurista soviético perseguido por Stalin (vemos bem o motivo), que dizia: "Uma vez estabelecida a forma da troca de equivalentes, estabelece-se igualmente a forma do direito, a forma do poder público, isto é, estatal [...]." (Pachukanis. Teoria Geral do Direito e Marxismo, p. 28.) Também Adorno diz que "o contrato social imaginário era tão bemvindo para a primeira época do pensamento burguês porque ele colocava à sua base a racionalidade burguesa, a relação de troca, enquanto a priori jurídico formal [...]." ${ }^{\text {469 }} \mathrm{Ou}$ seja, não se trata da afirmação mais ou menos banal de que o Estado e o direito servem aos interesses das classes dominantes (o que não deixa de ser verdade), mas de que a forma jurídica é coextensiva à abstração real da identidade posta pela forma da troca de mercadorias, que é por sua vez calcada na dominação do trabalho abstrato.

${ }^{470}$ Tal tipo de filosofia moral (sic) profissionalizada e racionalizada é empregada no mercado nos âmbitos mais diversos da decision making, desde a "ética empresarial" até à programação de carros automáticos com "moralidade algorítmica" (!), em que "carmakers must solve an impossible ethical dilemma of algorithmic morality". Cf. "Why Self-Driving Cars must be programmed to kill”, MIT Technology Review, Disponível em: 
de ethical decision making é algo meramente funcional, que mantém intactas as normas da dominação social, e se opõe a tudo aquilo que estamos considerando aqui. De todo modo, retornando à citação de Adorno: aquela reação ao insuportável que leva à ação que visa transformar a situação possui, como foi dito, um "momento irracional". Porém, esse momento irracional do sentimento de que algo é insuportável, de que aquilo deve ser transformado, não é puramente uma reação corporal ou pulsional. Ele nasce junto com um discernimento e é portanto inseparável de um conhecimento das coisas. Adorno diz ainda sobre aquele caso de mobilização para a resistência: "Se ele não tivesse tido esse discernimento, se ele não tivesse tido o conhecimento do mau [Schlechten], do sórdido, que outrora dominou a Alemanha, então certamente ele não teria sido movido para a resistência." ${ }^{471}$ Por essa razão, junto com essa reação ao inaceitável, deve ser considerada a centralidade desse conhecimento do mau (que é, também, um conhecimento do mal), diante do qual perde-se toda inocência, e que aponta, em direção contrária ao que eu vinha expondo aqui, à dimensão profundamente intelectual da moral.

\title{
Intelectualismo moral e desconforto
}

\author{
Quero que meu soneto no futuro \\ não desperte em ninguém nenhum prazer \\ [...] \\ Esse meu verbo antipático impuro \\ há de pungir, há de fazer sofrer \\ Drummond, Oficina irritada
}

Com razão, vários dos debates recentes em torno da teoria crítica de Adorno em geral, e de suas discussões sobre a moral em particular, trouxeram à tona o problema do sofrimento social e a dimensão pulsional da moral (algo efetivamente incontornável nesse contexto). ${ }^{472}$ Em muitos casos, o sofrimento aparece em Adorno como forma de sanar um

\footnotetext{
https://www.technologyreview.com/s/542626/why-self-driving-cars-must-be-programmed-tokill/ (último acesso em: 05/01/2019).

${ }^{471}$ PdM, p. 20.

${ }^{472}$ Cf. E Renault, "A critical theory of social suffering", e V. Safatle, "Sobre a gênese psicológica do transcendental: Adorno entre Freud e Kant". Também sobre a dimensão da mímesis na moral em Adorno, ver: Jeanne-Marie Gagnebin, "Uma filosofia moral negativa?" e Douglas Garcia Alves Júnior, Dialética da Vertigem: Adorno e a filosofia moral, que defende como "fundamento da racionalidade propriamente moral das ações humanas" a "ideia de uma racionalidade estética".
} 
certo "déficit normativo" da teoria ${ }^{473}$, na medida em que o sofrimento social real aparece como o índice de que aquilo que é não deve ser. "A dor diz: pereça" - essa citação de Assim falou Zaratustra na Dialética Negativa torna-se um lema do materialismo adorniano que encontra no corpo e nas pulsões seu teor normativo. De algum modo, tais leituras não escapam ao contexto daquilo que foi chamado de "virada afetiva" da teoria crítica em Honneth, ${ }^{474}$ que, em mais um capítulo do romance familiar da teoria crítica que se estrutura como um conflito de gerações ${ }^{475}$, busca superar o alvo da vez, a saber, o racionalismo kantiano sem corpo e sem afetos de Jürgen Habermas. Gostaria de, como exercício de contraponto, defender que há em Adorno um profundo intelectualismo moral, e que, apesar da centralidade do corpo e dos sentimentos para o problema da moral, temos, ao fim e ao cabo, um "primado da cabeça" bastante hegeliano (e marxista), que por sua vez se vincula ao sentido estratégico de toda teoria crítica na superação da dominação real e à dialética entre moral e política com a qual começamos este capítulo. Com isso tentamos não só evitar que o "corpo", elevado a princípio, torne-se ele mesmo uma abstração vazia e descarnada, mas enfatizar o sentido moral do pensamento.

Na Minima Moralia, Adorno escreve que "a inteligência é uma categoria moral." ${ }^{476} \mathrm{Na}$ fala livre de uma aula (ou seja, sem o rigor estilístico do ensaio), Adorno diz de forma mais explícita: "Se os homens não angariam força para a crítica, para compreender a mentira, então essa falta de força é também uma falta moral. Também a burrice e a incapacidade intelectual são uma categoria dinâmica. Em certo sentido, os homens carregam a responsabilidade moral por sua burrice. O fracasso intelectual é também ao mesmo tempo fracasso moral." ${ }^{\text {477 }} \mathrm{E}$ ainda, apesar da célebre situação aporética do "não há vida correta na falsa", em que a ausência de indicação sobre o agir moral aparece como decorrência de uma situação "sem saída", Adorno ousa até mesmo responder a pergunta sobre "que fazer" com... uma indicação para a vida correta (embora trate-se de uma indicação "mínima”). Ele diz (também na fala livre de uma aula): "Não há nenhuma outra indicação para a vida correta senão tentar, com todo o esforço do

\footnotetext{
${ }^{473}$ Cf. Amaro Fleck, "Da crítica imanente à crítica do sofrimento: a justificação normativa na obra tardia de Theodor W. Adorno" e Natalia Baeza, "The normative role of negative affects and bodily experience in Adorno".

${ }^{474}$ Filipe Campello, "A virada afetiva na teoria crítica de Axel Honneth".

${ }^{475}$ Luiz de Caux, A imanência da crítica: Estudo sobre modeloos sentidos sa crítica na tradição Frankfurtiana. Tese de Doutorado, UFMG, 2019.

${ }^{476}$ MM, p. 193.

${ }^{477}$ PM 1, 18/12/1956
} 
pensamento, conhecer da forma mais não ideológica possível as coisas que importam. ${ }^{„ 478}$ Ora, isso não deve espantar, afinal essa foi a forma como o autor conduziu sua vida. De todo modo, independentemente da contingência da vida empírica do professor e escritor Adorno: se a verdade é um conceito central de sua "filosofia prática" e da teoria crítica em geral, e se não há verdade sem pensamento, sem esforço intelectual, a atividade do crítico (quando ele acerta, quando ele torna-se, assim, útil - no sentido brechtiano) é moral. Também para Rosa Luxemburgo "dizer o que é permanece o ato mais revolucionário". Se há em Adorno um compromisso (e como ele diz, as pessoas tornamse responsáveis pela própria burrice), é o de, dito de forma simples, compreender as coisas como elas são, como algo necessário para que se possa resistir a elas. A própria Minima Moralia é entendida como uma pesquisa da configuração alienada da vida ${ }^{479}$. Ou seja, a moral está menos do lado de indicar como agir, e mais em explicar as coisas como elas $s \tilde{a} o^{480}$ (de forma a contribuir, indiretamente, para o agir correto, acertado). E isso já é demais, é uma Überforderung, pois “o que pode nos ajudar para uma ação correta é tentarmos trazer toda a complexidade para nossa razão e então tentar agir. Somos com isso sobrecarregados [überfordert], mas a essência da moral [Moralischen] é a exigência excessiva [Überforderung]. ${ }^{, 481}$ Ou seja, apesar da centralidade do prazer corporal, sem o qual qualquer ideia de felicidade (cerne da utopia) perde sentido, a Dialética Negativa é tudo, menos uma filosofia do prazer (embora Alfred Schmidt tenha identificado um hedonismo em Adorno, este hedonismo está antes ligado à utopia, e não ao trabalho

\footnotetext{
${ }^{478}$ PM 1, 28/02/1957

${ }^{479}$ MM, p. 9.

${ }^{480}$ Em outro momento do curso, Adorno reforça: "Vida correta está hoje vinculada à reflexão sobre as condições objetivas nas quais estamos presos [eingespannt]. [...] De certa forma, isso soa heterodoxo frente às concepções tradicionais de moral.” PM 1, 29/11/1956

481 PM 1, TWAA. Porém, alguns anos depois, no curso de 1963, Adorno diz sobre a Überforderung: "[...] genau diese Art der Überforderung liegt ja in der gesamtprotestantischen Tradition, der, wie man mit Recht immer wieder festgestellt hat, Kant - und zwar gerade der Moralphilosoph Kant - selber zugehört." PdM, p. 151. E ao redigir a Dialética Negativa, Adorno chega a afirmar: "Para designar uma tal decadência não da moral, mas do moral, a engenhosa língua alemã do pós-guerra fabricou o termo Überforderung [exigência excessiva], por sua vez um instrumento apologético.” DN, p. 204.
} 
intelectual $^{482}$ ). A atividade intelectual e moral não é necessariamente prazerosa, pelo contrário: ela é penosa ${ }^{483}$, dolorosa e sacrificial.

Quem se submete à disciplina dialética, tem de pagar sem qualquer questionamento um amargo sacrifício em termos da multiplicidade qualitativa da experiência. O empobrecimento da experiência provocado pela dialética, empobrecimento que escandaliza as opiniões razoáveis e sensatas, revela-se no mundo administrado como adequado à sua monotonia abstrata. O que há de doloroso na dialética é a dor em relação a esse mundo, elevada ao âmbito do conceito. ${ }^{484}$

Como notou Raymond Geuss, há, para Adorno, uma convergência entre conhecer e sofrer, e ele enfatiza um certo sofrimento intelectual. Os sofrimentos do mundo são espiritualizados no conhecimento, e o conhecimento das coisas (no caso, da desgraça objetiva), da qual depende toda crítica e resistência, traduz-se necessariamente em sofrimento do "espírito que conhece":

Somente um portador do espírito [Träger des Geistes] dispõe dos meios conceituais necessários para elaborar cognitivamente de forma adequada o sofrimento produzido por nossa sociedade. Somente um espírito cognoscente [ein erkennender Geist] está em condições de efetivamente exercer crítica à desgraça existente e resistir a ela. Sofrer é o preço que se paga pelo potencial crítico do espírito, pois no espírito conectam-se intimamente conhecimento, possibilidade de crítica e resistência, e capacidade de sofrer [Leidensfähigkeit]. O pensamento de Adorno é uma filosofia do espírito que sofre [Philosophie des leidenden Geistes]. ${ }^{485}$

\footnotetext{
${ }^{482}$ Embora Adorno também admita uma experiência de felicidade no pensamento: "Quem pensa não se enfurece na crítica: o pensamento sublimou a fúria. Uma vez que aquele que pensa não força a si mesmo, ele também não quer forçar os outros. A felicidade que surge em seus olhos é a felicidade da humanidade. A tendência universal de repressão vai contra o pensamento enquanto tal. Ele é felicidade, mesmo ali onde determina a infelicidade: na medida em que a expressa. Somente assim a felicidade penetra na infelicidade universal. Quem não permite isto definhar não se resignou." Adorno, "Resignação", in Cadernos de filosofia alemã.

${ }^{483}$ Esse caráter "penoso" aparece também na própria ideia de engajamento (sem entrar nos detalhes sartrianos), vinculada à "consciência do dever" tal como diz o intelectual brasileiro que, de forma mais nítida, atribuía à atividade intelectual (e política) um caráter moral, a saber, Antonio Candido, como diz ele em depoimento: "Fiz sempre militância política como um dever. Um dever quase que sempre penoso. Foi uma coisa que eu me impus. Eu não tenho temperamento político, eu não tenho espírito associativo, e eu não tenho ânimo combativo. Então eu sou a própria negação da política. Ora, por que então que eu passei a minha vida inteira envolvido com política? Por consciência do dever." Depoimento gravado e reproduzido em: https://www.youtube.com/watch?v=c4dOL61fHUA

${ }^{484}$ DN, p. 14.

${ }^{485}$ GEUSS, Raymond. Leiden und Erkennen (bei Adorno). in: HONNETH, Axel (Org.). Dialektik der Freiheit: Frankfurter Adorno-Konferenz 2003. Suhrkamp: Frankfurt am Main, 2005, pp. 4142.
} 
Um nietzscheano se escandalizaria e veria aí a confirmação de que dialética é coisa de cristão. De todo modo, o trabalho da crítica dialética parte do contexto universal de culpa, que não é outra coisa senão a própria totalidade social, "o mal relativo a essa totalidade": o pecado original secularizado. ${ }^{486}$ É uma maneira singular e engenhosa de vincular o indivíduo à dimensão impessoal da dominação abstrata ${ }^{487}$, pela qual ele se torna responsável, culpado. Ou seja, ao mesmo tempo em que a "injustiça do mundo" é algo antes vinculado ao todo da sociedade, Adorno tem em mente que "na concepção

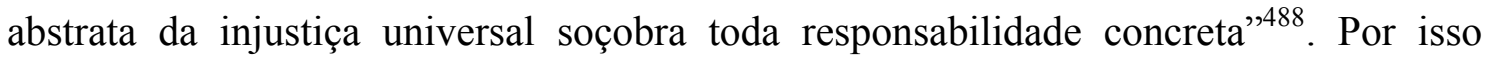
Adorno transforma a totalidade social em um "contexto de culpa" que se torna a mediação necessária, da qual não se pode virar os olhos, entre o crítico, seu objeto, e os sofrimentos da humanidade. Apesar do desejo utópico de ver-se livre do peso do mundo, essa Überforderung moral faz com que o intelectual sinta em suas costas os sofrimentos do mundo no imperativo de produzir uma compreensão correta das coisas.

Exposto dessa forma como fiz acima, em tal "indicação para a vida correta", o problema da moral parece resolver-se de forma excessivamente rápida com o recurso

\footnotetext{
${ }^{486}$ DN, p. 204. Mais adiante, Adorno afirma que Marx e Engels traduziram o pecado original da humanidade na economia política, na totalidade da relação de troca. Ibid., p. 268. A ideia de um "contexto de culpa", entretanto, vem de Walter Benjamin. O termo aparece diversas vezes sobretudo em seu ensaio sobre as Afinidades Eletivas de Goethe e em Destino e caráter, cuja complexidade e densidade exigiria uma incursão mais aprofundada e demorada. Mas podemos pensar que um dos cernes da questão de Benjamin é a relação entre culpa e desgraça da história: "O destino revela-se, portanto, na observação de uma vida como algo de condenado, no fundo como algo que começou por ser condenado para depois ser culpado. Goethe resumiu essas duas fases nas palavras: 'Vós fazeis dos pobres culpados'. O Direito não condena à punição, mas à culpa. O destino é o contexto de culpa em que se inserem os vivos [...]." Walter Benjamin, "Destino e caráter" in $O$ anjo da história. No fragmento "Capitalismo como religião" há uma concepção talvez mais próxima de Adorno, articulando capitalismo e culpa: "O capitalismo é provavelmente o primeiro caso de um culto que não redime, mas deixa um sentimento de culpa." O capitalismo é o próprio acúmulo de culpa/dívida (Schuld): "O capitalismo sem arrependimento tornou-se socialismo com juros acumulados que, enquanto tal, são função da culpa." W. Benjamin, "Capitalismo como religião" in $O$ anjo da história. Particularmente em Benjamin, a culpa está inscrita em uma relação temporal, como dívida em relação aos que virão (e aos que passaram). Como diz ele em um fragmento: "Um estado do mundo, no entanto, é apenas, e sempre, culpa (na sua relação com um outro, que virá depois dele. Mas a inversa pede reflexão: se ele também é um estado de culpa em relação a outro que veio antes." Walter Benjamin, $O$ anjo da história.

${ }^{487}$ Entende-se aqui a dominação do valor, tal como desenvolvida nos primeiros capítulos d' $O$ Capital e analisada por Moishe Postone em Time, Labor, and Social Domination.

${ }^{488} \mathrm{MM}$, p. 21. Não é incomum, portanto, o desconforto político frente a que, ao enfatizarem a dimensão da dominação impessoal e abstrata do valor (e enxergarem a dominação subjetiva de classes não como estrutural, mas fenomênica), dão a impressão de ser possível, com isso, "lavar as mãos".
} 
apelativo a um documento de arquivo. E se Adorno nomeou dois cursos de "Problemas de filosofia moral", é porque é constitutivo da moral ela ser um problema, e não uma solução. E a ideia de que haveria, afinal, uma indicação para a vida correta, faz transparecer uma segurança moral e um conforto para aquele que simplesmente respeita a divisão social do trabalho - o que seria excessivamente miserável frente à complexidade do problema, e o que contradiria a ideia de que "não existe segurança moral; pressupô-la seria já imoral"489. Além do mais, faz parte da moral justamente a falibilidade da insegurança e o desconforto ${ }^{490}$, não como um valor em si, mas como algo do qual depende o inconformismo. Afinal, é na insatisfação que surge a "aspiração utópica da alma", como escrevia o jovem Lukacs na Teoria do Romance:

[...] a aspiração utópica da alma só é legítima, só é digna de tornar-se o centro de uma configuração do mundo, se for absolutamente incapaz de satisfazer-se na presente situação do espírito, ou, o que dá no mesmo, num mundo presentemente imaginável ou configurável, quer seja passado ou mítico. Caso se encontre um mundo da satisfação, isso provará que o descontentamento com o presente era uma critiquice [...], um fascínio decorativo [...]. ${ }^{491}$

\section{Seriedade, silêncio, vergonha}

\section{Em muitos homens é já uma falta de vergonha dizer eu. Adorno, Minima Moralia}

A insatisfação genuína e o sentimento do peso do mundo produzem um estado de permanente seriedade. Quando Jay Bernstein fala de uma "intensidade ética",492 onipresente na escrita adorniana, ela não significa outra coisa senão intensa seriedade (por vezes entendida como "pessimismo"), que se exprime, sobretudo, em um estilo da escrita que busca fazer justiça à seriedade da situação, uma situação em que "nada mais é inofensivo" ${ }^{493}$. Essa seriedade engendra uma forma particular de materialismo, que é,

\footnotetext{
${ }^{489}$ DN, p. 204.

490 “[...] faz parte da moral não se sentir em casa na própria casa.” MM, p. 35

${ }^{491}$ Georg Lukacs, Teoria do Romance, p. 121.

492 J. M. Bernstein, Disenchantment and Ethics, p. xi.

${ }^{493}$ MM, p. 21. Não é o caso de Adorno, mas cabe lembrar que sempre há o risco de transformar qualquer postura moral (e inclusive a seriedade) em um fim em si, tal como Günther Anders acusa o existencialismo de ter se tornado "uma fuga das tarefas sérias da época em direção à seriedade como tarefa." Günther Anders, Nihilismus und Existenz (completar referência)
} 
digamos assim, um materialismo da realidade bruta, frente à qual todo o resto torna-se futilidade inocente. ${ }^{494}$ Jean Améry, narrando a experiência no campo, discorre sobre esse rebaixamento de toda transcendência à crua materialidade das coisas imanentes:

O ser converteu-se definitivamente em um conceito disforme e vazio. Aos nossos olhos, discursar sobre a real existência humana parecia não só uma brincadeira inútil e fútil, que não deveria ser permitida, mas algo sarcástico e perverso. O mundo fenomênico nos oferecia a toda hora a prova de que seu caráter insuportável só podia ser enfrentada com meios imanentes. Em outras palavras: em nenhum outro lugar no mundo a realidade se impunha de forma tão eficaz quanto no campo; em nenhuma outra parte ela era tão verdadeira; em nenhum outro lugar a tentativa de superá-la se revelava tão sem perspectiva e sem esperança. Assim como os versos sobre muros mudos e bandeirinhas tremulantes ao vento, também perdiam transcendência as teses filosóficas, que para nós se tornavam constatações objetivas ou pura tagarelice: quando significavam algo, pareciam triviais; quando não eram triviais, não significavam nada. Reconhecer isso não exigia nenhuma análise semântica, nenhuma sintaxe lógica: bastava olhar para a torre de vigilância ou sentir o cheiro de gordura queimada que vinha do crematório. ${ }^{495}$

Este trecho pode valer como síntese do que Adorno postulou como o problema da “metafísica após Auschwitz”, que poderia ser traduzido como a metafísica após sua aniquilação, ou como tentativa de pensar a transcendência depois que não há mais possibilidade de transcendência (em que parece desaparecer até mesmo aquela "instância intramundana da transcendência" buscada por toda teoria crítica, como diz Honneth ${ }^{496}$ tal ideia é, a rigor, a própria essência da dialética, que, a partir do negativo, produz uma transcendência a partir da imanência). No Campo, como diz Améry, a realidade se impôs de modo "tão eficaz" que a "tentativa de superá-la se revelava [...] sem esperança e sem perspectiva". ${ }^{497}$ Não quero entrar aqui no problema da metafísica, mas ressaltar esse tipo

\footnotetext{
${ }^{494}$ Mesmo o empenho teórico da crítica possui algo de ridículo quando se reconhece, como diz Adorno, "a discrepância entre assassinar os judeus, enterrá-los vivos pois não valiam o segundo tiro, e a teoria da qual se espera que transforme o mundo." Towards a new manifesto.

495 Jean Améry Além de crime e castigo, p. 50-51 (tradução alterada). Note-se que aqui, igualmente, prescinde-se da justificação e do apelo discursivo.

${ }^{496}$ Axel Honneth, "Die Pointe der Anerkennung: eine Entgegnung auf die Entgegnung", p. 272.

${ }^{497}$ É nesse contexto de transcendência da realidade, de ir além dessa horrível imanência, que a metafísica, em Adorno, ganha uma dimensão utópica. A ideia de refletir sobre a "metafísica após Auschwitz" na Dialética Negativa, porém, não foi bem recebida por Jean Améry, que, em um texto equivocado sobre dialética (e contra Adorno), diz: "É suficientemente irritante para aquele que infelizmente foi atingido o fato de que mais uma vez Auschwitz deve servir para inspirar um exercício dialético.” Jean Améry, “Jargon der Dialektik”, Merkur (1967), p. 1055.
} 
de imposição ao pensamento que significa Auschwitz, que é algo como um excesso de realidade que produz um "confronto entre o espírito e o horror" isso, e não tanto uma solenidade ou ritual de respeito.

A seriedade, tradicionalmente, exprime respeito diante de algo sacro, ou diante da morte, como por exemplo na concepção de moral que o personagem Hans Castorp desenvolve n'A Montanha Mágica: "Parece-me que o mundo e a vida foram feitos de sorte que deveríamos andar sempre de preto, com uma golilha engomada em lugar do colarinho, e manter uns com os outros relações graves, reservadas e formalistas, recordando-nos da morte. Gostaria que assim fosse. Acho que isso corresponde à moral." ${ }^{499}$ Ela pode corresponder ainda a uma posição diante do poder e da autoridade daí a marca da obediência, como diz Adorno a respeito de uma seriedade convertida em "tom solene": "O tom solene condenaria as obras de arte ao ridículo tal como o comportamento de poder e de majestade. ${ }^{, 500}$ Em uma situação em que a seriedade solene faz parte da dominação e de sua mise en scène, a ironia que expõe o ridículo possui força crítica enquanto desvelamento da fachada sisuda. Surge daí a relação íntima entre iluminismo, crítica e sátira. Essa é a função crítica da sátira que, de forma materialista, rebaixa o solene e elevado ao parterre do citoyen.

O célebre aforismo "Erro de Juvenal" da Minima Moralia, entretanto, atesta a falência da ironia. ${ }^{501}$ A situação que produz esse fracasso da sátira e que exige uma “sanguínea seriedade” é, lê-se entre as linhas, o fascismo. "É difícil escrever uma sátira. Não só porque a situação que mais necessita delas do que qualquer outra zomba de toda zombaria. A própria ironia como meio entrou em contradição com a verdade." ${ }^{\natural 02}$ Antes, o engodo da ideologia burguesa em seu momento de ascensão consistia, dito de forma simples, num encobrimento da realidade, na medida em que havia uma discrepância entre a realidade e aquilo que ela promete ser. A contraposição dessas duas instâncias no interior dessa discrepância, é, digamos assim, o momento objetivo da ironia. Daí a afinidade entre ironia e crítica imanente, que, dialeticamente, contrapõe a realidade a seu próprio conceito, isto é, critica o objeto a partir de suas próprias normas - não a fim de

\footnotetext{
${ }^{498}$ Jean Améry, Além de crime e castigo, p. 33.

${ }^{499}$ Thomas Mann, A Montanha Mágica

${ }^{500}$ Adorno, Teoria Estética, p. 68.

${ }^{501}$ Cf. Vladimir Safatle, Cinismo e falência da crítica.

${ }^{502}$ MM, p. 206
} 
tomar tais normas como constantes, mas de modo que, neste movimento de fazer a realidade efetivar seu próprio conceito (no movimento da negação determinada, na linguagem da dialética), nem o conceito nem a realidade permanecem como antes. $\mathrm{O}$ problema é que, na leitura frankfurtiana, o fascismo, e não a Revolução, é a verdade da história: o fascismo é o capitalismo que coincide com seu próprio conceito. ${ }^{503}$ Neste momento a realidade não promete mais nada, senão ela mesma. A ideologia não encobre a realidade, mas é a duplicação cínica da própria realidade no gesto do "so ist es":

O meio da ironia, a diferença entre ideologia e realidade, desapareceu, resignada à confirmação da realidade na sua mera duplicação. A ironia exprimia: assim a coisa pretende ser e assim ela é de fato; hoje, contudo, o mundo proclama mesmo na mentira radical que é assim mesmo, e essa simples descoberta lhe parece coincidir com o bom. Na rocha do existente nenhuma fenda dá apoio à mão do irônico. ${ }^{504}$

\footnotetext{
${ }^{503}$ Nesse contexto, pode-se dizer que, assim como para Benjamin, Adorno não compreende a Revolução como o destino para o qual a história caminha. Pelo contrário: a história é um acúmulo de catástrofes - na Dialética Negativa, Adorno diz: "Depois das catástrofes passadas e em face das catástrofes futuras, a afirmação de um plano do mundo dirigido para o melhor, um plano que se manifesta na história e que a sintetiza, seria cínica. [...] Não há nenhuma história universal que conduza do selvagem à humanidade, mas há certamente uma que conduz da atiradeira até a bomba atômica." DN, p. 266. A Revolução é portanto uma descontinuidade - nos termos de Benjamin, ela é o freio de emergência da locomotiva desvairada do progresso que conduz a humanidade para o abismo.

${ }^{504}$ MM, p. 208. Rahel Jaeggi reconhece que em uma tal situação a "crítica interna" não poderia funcionar: "Em uma sociedade sem ideais ou em uma sociedade que teria se dedicado inteiramente ao cinismo, a crítica interna, de certo modo, não encontaria nenhum apoio. E também uma sociedade, que teria colocado sua estrutura de normas [Normengefüge] de forma consistente e em conformidade com sua práxis em favor da crueldade e da maldade, não se permitiria criticar internamente. A crítica interna só pode então criticar uma práxis ruim ali onde ela entra em contradição com as normas pré-existentes." R. Jaeggi, Kritik von Lebensformen. Entretanto, contra a tese de Adorno a respeito de uma reprodução cínica da realidade (que Habermas levou adiante em sua análise da tecnocracia que não promete uma "vida boa" e sim tão somente o bom funcionamento daquilo que é), Rahel Jaeggi defende que uma tal "desnormatização" da sociedade seria impossível, isto é, que uma sociedade não poderia abandonar suas normas, sem as quais sequer existiria sociedade: "[A crítica imanente] não precisa temer que a realidade perca, de forma cínica, seus ideais. Uma realidade (social) 'sem normas' não pode sequer existir a partir da perspectiva da crítica imanente. Se o discurso de 'normas' se refere não somente a 'valores' partilhados, mas sim a princípios funcionais normativos, então sem essas normas uma ordem social sequer é pensável.” Ibid. Entretanto, penso que nem Adorno nem Habermas acreditariam que as normas de funcionamento da sociedade teriam deixado de existir - uma sociedade ruim pode funcionar muito bem (ou mesmo que ela não funcione tão bem, ela ainda pode "prometer" seu bom funcionamento). Ou seja, de fato, a crítica imanente de engenheiro, que crítica o mal funcionamento de uma máquina, não precisa temer que ele não terá critérios aos quais se referir ao fazer sua "crítica". Entretanto, a crítica dialética não parte de "princípios funcionais normativos", visto que tais princípios não levariam a nenhum lugar a não ser eles mesmos. De
} 
Nesta situação, “contra a sanguínea seriedade da sociedade total, [...] apenas resta a sanguínea seriedade da verdade compreendida." ${ }^{505} \mathrm{O}$ riso torna-se cúmplice da dominação. Vale notar que a cumplicidade (Mitschuld, termo recorrente em Adorno) ganha centralidade ao articular culpa e passividade: quem não faz nada também é culpado. E a "sanguínea seriedade" é também uma resposta a uma situação onde, justamente, não há inocência. A inocência e a ingenuidade tornam-se crimes morais, como escrevia Brecht em seu poema Aos que vão nascer:

Realmente, vivo em tempos sombrios.

A palavra inocente é tola. Uma testa sem rugas Indica insensibilidade. Aquele que ri Apenas ainda não recebeu A terrível notícia.

Que tempos são esses, em que Falar de árvores é quase um crime Pois implica silenciar sobre tantas barbaridades? $[\ldots]^{506}$

As rugas na testa, expressão da seriedade, são a reação corporal à "terrível notícia". A inocência é tolice ou insensibilidade. ${ }^{507}$ A frugalidade das pequenas belezas torna-se uma ignomínia, pois encoberta a avalanche de horror. A brutal seriedade surge no momento em que se encara o horror. A seriedade na arte diante do fascismo é, portanto, menos um culto solene à sua própria sacralidade, mas uma resposta ética e política ao estado de coisas, como na pintura de um George Grosz, sobre a qual Günther Anders comenta: “Onde a vida se enfeita com o celofane brilhante da 'aparência alegre', é tarefa da arte tornar-se 'séria', vingando-se ao estraçalhar e descreditar o contínuo de entretenimento do cotidiano. $" 508$ O poema de Brecht, no qual nem as árvores são

todo modo, uma "crítica interna" que não se interessa por outra coisa a não ser aquilo que já existe não precisa de fato se preocupar com transformações históricas.

${ }^{505}$ MM, p. 208.

${ }^{506}$ Brecht, Poemas (tradução modificada).

${ }^{507}$ Deve-se suspeitar não só da inocência, como de toda serenidade livre de aflição, como diz Adorno, ao comentar o necrológio de um empresário: "Quando se elogia num homem de idade avançada que tenha sido especialmente sereno, é de presumir que sua vida representou uma sequência de patifarias. Ele se desabituou da aflição. [...] Quem não é mau não vive sereno, mas endurecido e impaciente de maneira privada, envergonhada." MM, p. 21. No aforismo seguinte (no qual nota-se a referência ao poema de Brecht), Adorno escreve: "Recomenda-se desconfiança perante toda desenvoltura, toda ligeireza, diante de todo deixar-se levar que envolva concessão ao império do existente." Ibid.

${ }^{508}$ Günther Anders, "George Grosz" in Mensch ohne Welt: Schriften zur Kunst und Literatur, p. 204. 
inocentes, e que caracteriza a ignomínia da frivolidade diante da seriedade da situação, é retomado tematicamente diversas vezes em Adorno:

Nada mais é inofensivo. As pequenas alegrias, as expressões da vida que parecem isentas da responsabilidade do pensamento não só contêm um elemento de obstinada tolice, de impassível endurecimento, como se põem imediatamente a serviço do seu extremo oposto. Mente até mesmo a árvore florida no instante em que se percebe seu florescimento sem a sombra do sobressalto; mesmo o inocente 'que bonito' torna-se desculpa para a ignomínia da existência, que é diferente, e não há mais beleza nem consolo exceto no olhar que vai até o horror, o enfrenta e mantém a possibilidade do melhor na consciência não abrandada da negatividade. ${ }^{509}$

Para Adorno, essa seriedade inconsolável (que é o "olhar que vai até o horror" e a "consciência não abrandada da negatividade") exprime-se esteticamente, sobretudo, de duas formas: na cor negra e no silêncio. Igualmente contra o "celofane brilhante" da indústria cultural, Adorno escreve na Teoria Estética: "Para subsistir no meio dos aspectos mais extremos e sombrios da realidade, as obras de arte que não querem venderse como consolo deviam tornar-se semelhantes a eles. Hoje em dia, arte radical significa arte sombria, negra como sua cor fundamental." ${ }^{, 510}$ Nessa negação do frugal das cores há, sem dúvida, um elemento ascético: "O negro e o cinzento da arte moderna, a sua ascese das cores é negativamente a sua apoteose." ${ }^{, 511}$ Em alemão, a afinidade entre o cinza (grau) e o horror (das Grauen) é ainda mais evidente. O escuro e a cor negra na arte é o reconhecimento de seu enleamento na Finsternis (escuridão, trevas) objetiva, nas trevas reais dos "tempos sombrios" [finstere Zeiten] de Brecht, que Adorno chamou de "methexis am Finsternis [methexis nas trevas]": "Na sua tensão para a catástrofe permanente, a negativiade da arte está ligada à méthexis na obscuridade." ${ }^{\text {" }} 12$ o silêncio é igualmente uma resposta a essa methexis, que é também uma culpa, afinal "as obras de arte são a priori socialmente culpadas." ${ }^{, 513}$ Essa resposta é uma tentativa de expiação:

\footnotetext{
${ }^{509}$ MM, p. 21. Tradução modificada. Para um comentário sobre a referência a Goethe no título deste aforismo ("Herr Doktor, das ist schön von Euch" - um verso do Fausto) e a culpa que permeia a relação entre intelectual e povo, cf. Bruno Carvalho, Psicanálise e crítica social em Adorno.

${ }^{510}$ TE, p. 68 (tradução modificada).

${ }^{511}$ TE, p. 208.

${ }^{512}$ Ibid.

513 TE, p. 353. "Na cultura rescuscitada depois da catástrofe, a arte aceita totalmente, mediante a sua simples existência, antes de todo o conteúdo, um elemento ideológico. A sua desproporção em relação ao horror passado e ameaçador condena-a ao cinismo; daí ela se desvia quando se lhe
} 
"Enquanto que toda e qualquer obra bem sucedida transcende a culpa, todas devem expiála e, por isso, a sua linguagem gostaria de regressar ao silêncio: é, segundo uma expressão de Beckett, uma desacration of silence." ${ }^{514}$ Adorno evoca também o silêncio, em um trecho sobre o belo natural, como uma relação de não-violência com o objeto, que denota, tradicionalmente, respeito (nesse caso, respeito àquilo que é mudo): “A expressão 'Que belo' perante uma paisagem fere a sua linguagem muda e diminui a sua beleza; a natureza fenomenal quer silêncio [...]." ${ }^{, 515} \mathrm{O}$ silêncio na arte busca alcançar essa natureza muda das coisas: "Se a linguagem da natureza é muda, a arte aspira a fazer falar o silêncio [...]." "516 Essa contradição de "fazer falar o silêncio" é central para a ideia adorniana de expressão, de modo que, não menos sério que o silêncio, a natureza que sofre se exprime também no grito (Beckett formaliza não só o silêncio, mas também o grito, por exemplo, na fala mutilada de sua peça Not I): “O sofrimento perenizante tem tanto direito à expressão quanto o martirizado tem de berrar [...]." ${ }^{, 517}$ Em suma, pode-se dizer que a "sanguínea seriedade" tanto do silêncio quanto do grito (em ambos os casos, trata-se de formas não-discursivas da linguagem) é uma posição frente ao sofrimento próprio e alheio, e frente aos mortos (também a cor negra remete aos rituais de luto). Por isso, "a injustiça, que toda arte engraçada, sobretudo a de divertimento, gera, é uma injustiça para com os mortos, para com a dor acumulada e muda." ${ }^{18} \mathrm{O}$ oposto do silêncio é "a gargalhada sonora, o escárnio desmedido, a bárbara obscenidade que o potente dirige à impotência [...]." ${ }^{519}$

Não há como negar que essa seriedade, vinculada a sentimentos repressivos como vergonha e culpa, aparece como bloqueio do gozo e da satisfação, de modo que, com sua dimensão inibidora, ela poderia estar vinculada antes a uma neurose. Porém, nem toda

\footnotetext{
opõe. A sua objectivação implica a frieza perante a realidade. Isso degrada-a em cúmplice da mesma barbárie na qual cai sobretudo quando apoia a objectivação e nela toma imediatamente parte, mesmo se é através de um empenhamento polêmico. Hoje, toda a obra de arte, inclusive a radical, possui o seu aspecto conservador; a sua existência serve para reforçar as esferas do espírito e da cultura, cuja impotência real e cuja cumplicidade com o princípio da infelicidade aparecem a nu." TE, p. 352-353. (grifo meu).

${ }^{514}$ TE, p. 207.

515 TE, p. 111.

516 TE p. 125. Essa aspiração é análoga à ideia de que "a arte gostaria de com meios humanos realizar o falar do não-humano." (Ibid.) Uma aspiração contraditória que aparece também na Dialética Negativa: "A utopia do conhecimento seria abrir o não-conceitual com coneitos, sem equipará-lo a esses conceitos." DN, p. 17.

${ }^{517}$ DN, p. 300.

${ }^{518}$ TE, p. 69.

519 Adorno; Horkheimer, Dialética do Esclarecimento, p. 232.
} 
culpa é neurótica, como diz Adorno em aula: “A pressão sob a qual vivemos produz não só sentimentos de culpa neuróticos, mas também sentimentos de culpa bastante reais." ${ }^{\circ 20}$ Nesse contexto, Adorno via o sucesso comercial da psicanálise com sua promessa de "restaurar a capacidade de gozo" 521 ao liberar o indivíduo do sentimento de culpa que pesa sobre ele como parte de um mecanismo de adaptação funcional e dessensibilização social, de modo que o horror se efetiva, sem culpa nem vergonha. Daí a rejeição de Adorno em relação às promessas de cura da psicanálise, que serviria, ao fim e ao cabo, como adaptação dos indivíduos (com suas pulsões devidamente satisfeitas) a uma sociedade ruim, que ele precisa necessariamente desconhecer ou ignorar:

Pertence aos mecanismos da dominação proibir o conhecimento do sofrimento, e uma via reta leva do evangelho da alegria da vida à construção de matadouros humanos tão longe na Polônia que cada membro da comunidade nacional pode se iludir de não escutar os gritos de dor. Esse é o esquema da capacidade de gozo não perturbada. ${ }^{522}$

Esse tema é retomado no aforismo "Desmancha-prazeres", onde Adorno sugere que mesmo esse gozo recuperado não ocorre de forma ilesa: "ninguém que lucra no sistema de lucros logrará existir nele sem vergonha, e ela deforma mesmo o prazer não deformado"523 (aliás, a ideia do estraga prazeres se estende em Adorno desde essa convocação à seriedade da prosa teórica que pensa a partir da agonia do mundo até à negatividade da arte contra todo divertimento). Esse tema da culpa que bloqueia a satisfação aparecia já no poema de Brecht citado acima:

\footnotetext{
${ }^{520}$ PM 1, 6/12/1956. A culpa neurótica pode ser considerada como resultado de uma instância psíquica (no caso, o Super-eu) que funciona como se fosse um outro vigilante, que inflige a si a agressividade que gostaria de infligir no outro, como explica Freud: "A agressividade é introjetada, internalizada, mas é propriamente mandada de volta para o lugar de onde veio, ou seja, é dirigida contra o próprio Eu. Lá é acolhida por uma parte do Eu que se contrapõe ao resto como Super-eu, e que, como 'consciência', dispõe-se a exercer contra o Eu a mesma severa agressividade que o Eu gostaria de satisfazer em outros indivíduos. À tensão entre o rigoroso Super-eu e o Eu a ele submetido chamamos consciência de culpa; ela se manifesta como necessidade de punição." Freud, O Mal-Estar na Civilização, p. 69. A ideia de uma culpa real que era transfigurada ideologicamente em culpa neurótica ou "guilt complex" é discutida por Günther Anders em sua troca de cartas com o piloto de Hiroshima Claude Eatherly.

521 "A psicanálise se vangloria de restituir aos homens sua capacidade de gozo, que teria sido perturbada pelo mal neurótico.” MM p. 57.

${ }_{522}$ MM, p. 58.

${ }^{523}$ MM, p. 172. Aliás, o tema do aforismo inteiro é a condição eminentemente frustrada de toda satisfação no capitalismo: "A tristeza domingueira não é nostalgia da semana de trabalho, mas da condição dela emancipada; o domingo deixa insatisfeito não porque nele se festeja, mas porque sua própria promessa se apresenta de imediato como frustrada; tal como o inglês, todo domingo é demasiado pouco.” MM, p. 171
} 
As pessoas me dizem: Come e beba! Alegre-se porque tem! Mas como posso comer e beber, se

Tiro o que como ao que tem fome

E meu copo d'água falta ao que tem sede?

E no entanto eu como e bebo. ${ }^{524}$

Ou seja, não só o prazer, mas até mesmo a satisfação das necessidades fisiológicas é atingida pelo "contexto universal de culpa". Na Minima Moralia, isso aparece como "a vergonha de que no inferno ainda nos reste ar para respirar". ${ }^{525}$ No contexto do fascismo, é recorrente algo ainda mais radical: a vergonha de ter sobrevivido. No mesmo poema de Brecht, ele diz: "Mas acreditem: é puro acaso. Nada do que faço / Me dá direito a comer a fartar. / Por acaso fui poupado. (Se minha sorte acaba, estou perdido.)"526 Günther Anders escreve no texto Mein Judentum: "Porque eu não fui um prisioneiro de Auschwitz, porque eu por acaso escapei, eu me sinto como um desertor." ${ }^{257}$ Também Adorno escreve na Dialética Negativa:

Todavia, não é falsa a questão menos cultural de saber se ainda é possível viver depois de Auschwitz, se aquele que por acaso escapou quando deveria ter sido assassinado tem plenamente o direito à vida. Sua sobrevivência necessita já daquela frieza que é o princípio fundamental da subjetividade burguesa e sem a qual Auschwitz não teria sido possível: culpa drástica daquele que foi poupado. Em revanche, ele é visitado por sonhos tal como o de não estar mais absolutamente vivo, mas de ter sido envenenado com gás em 1944, e de depois disso não conduzir coerentemente toda a sua existência senão a partir da pura imaginação, emanação do louco desejo de alguém há vinte anos assassinado. ${ }^{528}$

Notemos que, nos três textos, é evocado o acaso e a sorte do sobrevivente também Primo Levi começa seu $E$ isto um homem? com a frase: "Por minha sorte, fui deportado para Auschwitz só em 1944 [...]." ${ }^{529}$ Há quem diga que esse "per mia fortuna"

\footnotetext{
${ }^{524}$ Brecht, Poemas. Seria interessante investigar a centralidade da fome em Brecht, e, de forma análoga, a carga metafórica do comer enquanto gula e pecado.

${ }_{525}$ MM, p. 24.

${ }^{526}$ Brecht, Poemas.

${ }^{527}$ G. Anders, Mein Judentum apud Gewalt - Ja oder nein, cit., p. 14. O tema da deserção e da traição é recorrente nas filosofias forjadas na resistência ao fascismo, como no existencialismo de Sartre. Não é por acaso que Alain Badiou, seguindo a herança sartriana, manterá a noção de engajamento em seu conceito de fidelidade. Cf. Badiou, L'être et l'événement. Paris: Seuil, 1988, p. $257 \mathrm{ss}$.

${ }_{528}^{5}$ DN, p. 300.

${ }^{529}$ Primo Levi, É isto um homem? Como informa a edição italiana, a fortuna é uma das palavras mais recorrentes na obra de Primo Levi.
} 
é um ponto de partida irônico. ${ }^{530}$ Porém, podemos pensar que evocar a sorte e o acaso aqui significa na verdade uma afirmação sobre o contrário, aliás, a necessidade e o destino (a desgraça que condena à culpa ${ }^{531}$ ), que se apresentou aos judeus como fatalidade incontornável: a morte. A questão que fica é pensar sobre a vida depois desse "acaso". A vida no mundo depois das catástrofes é a vida mergulhada na culpa, ao mesmo tempo em que o pós-guerra é marcado pela expansão desenfreada do consumo e da publicidade, que se desenvolvem sob as formas patológicas do consumismo e do imperativo do gozo (que se realiza, nos termos de Marcuse, como uma "dessublimação repressiva"). Anos mais tarde, Jean-François Lyotard dirá, em tom apologético, "nós temos, em relação a Adorno, a vantagem de viver em um capitalismo mais enérgico, mais cínico, menos trágico., ${ }^{, 52}$ Nesse caso, comemora-se a jouissance na barbárie restaurada por uma posição francamente cínica, que no auge do neoliberalismo torna-se uma espécie de nietzscheanismo da burguesia vencedora contra o ressentimento dos vencidos. Adorno já tinha em vista esse cinismo ao caracterizá-lo como "sem-vergonhice" [Unverschämtheit]:

As pessoas manipularam a tal ponto o conceito de liberdade, que ele acabou por se reduzir ao direito dos mais fortes e mais ricos de tirarem dos mais fracos e mais pobres o que estes ainda têm. [...] para as pessoas de temperamento livre, espontâneo, sereno e imperturbável, que da falta de liberdade extraem a liberdade como um privilégio, a linguagem reserva, prontinho, um nome apropriado: sem-vergonhice. ${ }^{533}$

É crucial observar que não se trata aqui de simplesmente reduzir a crítica do capitalismo (que requer interpretação conceitual) a algo que seria uma "crítica moralista" de uma forma social que se reproduz segundo mecanismos bastante objetivos. A moral (ou a deformação moral, no caso) é essencial para pensar estruturas psicológicas e sociais

\footnotetext{
${ }^{530}$ R. Gordon, "Per mia fortuna: Irony and ethics in Primo Levi's writings".

531 "Será a sorte, como sem dúvida o é a desgraça, uma categoria constitutiva do destino? A sorte parece ser, antes, aquilo que liberta quem a tem da cadeia dos destinos e da rede do seu próprio destino. Não é por acaso que Hölderlin diz que os deuses bem-aventurados 'escapam ao destino'. Também a sorte e a bem-aventurança, portanto, fogem à esfera do destino, tal como a inocência." Walter Benjamin, Destino e caráter.

532 Jean-François Lyotard, Des dispositifs pulsionnels. Paris: Galilée, 1994, p. 121.

${ }^{533}$ MM, GS 4, p. 289-290. (Tradução alterada a partir de uma tradução de Vera Ribeiro publicada em https://www1.folha.uol.com.br/fsp/1996/5/26/mais!/11.html ). A ideia de "sem-vergonhice" como falsa liberdade aparece também em "Segunda colheita", quando Adorno diz: "Testemunhos de que na sociedade repressiva a liberdade e a falta de vergonha dão no mesmo são os gestos petulantes dos adolescentes que perguntam 'quanto custa o mundo' enquanto ainda não vendem o seu trabalho. Para demonstrar que não dependem de ninguém e portanto não precisam ter respeito eles enfiam as mãos nos bolsos das calças. Quanto aos cotovelos que dobram para fora, estão prontos para bater em quem quer que se apresente no seu caminho.” MM, p. 106.
} 
e a agência de indivíduos no interior da sociedade capitalista (a reflexão moral torna-se, assim, essencial para a própria crítica da sociedade, e vice-versa ${ }^{534}$ ). Não é por acaso que é tarefa também da sociologia e da psicologia social críticas investigar os mecanismos pelos quais suspende-se qualquer inibição (como vergonha ou culpa) na realização do trabalho sujo, desde as tarefas zelosamente cumpridas no campo de concentração até as monstruosidades do mundo contemporâneo do trabalho cinicamente praticadas. ${ }^{535} \mathrm{Ou}$ seja, há uma objetividade social da moral. Por outro lado, a culpa e a vergonha são formas de implicação subjetiva e têm por isso uma dimensão política e uma relação com o problema do engajamento. ${ }^{536}$ Não é por acaso que Sartre considera a vergonha em $L$ 'être et le néant:

Considérons, par exemple, la honte [...] sa structure est intentionnelle, elle est appréhension honteuse de quelque chose et ce quelque chose est moi. J'ai honte de ce que je suis. La honte réalise donc une relation intime de moi avec moi: j'ai découvert par la honte un aspect de mon être. Et pourtant, bien que certaines formes complexes et dérivées de la honte puissent apparaître sur le plan réflexif, la honte n'est pas originellement un phénomène de réflexion. En effet, quels que soient les résultats que l'on puisse obtenir dans la solitude par la pratique religieuse de la honte, la honte dans sa structure première est honte devant quelqu'un. Je viens de faire un geste maladroit ou vulgaire: ce geste colle à moi, je ne le juge ni ne le blâme, je le vis simplement, je le réalise sur le mode du pour-soi. Mais voici tout à coup que je lève la tête : quelqu'un était là et m'a vu. Je réalise tout à coup toute la vulgarité

\footnotetext{
${ }^{534}$ Rahel Jaeggi, em um artigo sobre a Minima Moralia, notou que a reflexão moral em Adorno passa para o âmbito da crítica da sociedade. Cf. R. Jaeggi, "Kein Einzelner vermag etwas dagegen".

${ }^{535}$ A referência aqui é Christophe Déjours (Souffrance en France: la banalisation de l'injustice sociale), e interpretações dessa temática feitas por Paulo Arantes (Sale boulot: uma janela sobre o mais colossal trabalho sujo da história. Uma visão do laboratório francês de sofrimento social) e por Silvia Viana (Rituais de sofrimento).

${ }^{536}$ Também Marx, em carta a Ruge, se referia a uma potência política da vergonha: "[...] Você olha para mim com um sorriso e pergunta: o que se ganha com isso? Nenhuma revolução é feita por vergonha. Eu respondo: vergonha já é uma espécie de revolução. Vergonha é, na verdade, a vitória da Revolução Francesa sobre o patriotismo alemão que a derrotou em 1813. Vergonha é uma espécie de raiva que se volta para dentro. E, se uma nação inteira realmente experimentasse um sentimento de vergonha, seria como um leão agachado, pronto para dar um salto. Admito que, na Alemanha, a vergonha ainda não é sentida; pelo contrário, essas pessoas miseráveis ainda são patriotas. (...) A nau dos insensatos talvez pudesse ficar à deriva por um bom tempo, à mercê do vento, mas seria levada a enfrentar seu destino, precisamente porque os tolos não acreditariam nisso. Esse destino é a revolução iminente." Carta a Arnold Ruge, março de 1843. (Agradeço a Yasmin Afshar pela lembrança desta passagem). Walter Benjamin, nos fragmentos reunidos sob o título de "Antropologia e moral”, também se dedica à vergonha: "A cor da vergonha é pura: o seu vermelho não é nem colorido nem cor, mas colore [Färbendes]. É o vermelho do efêmero da paleta da fantasia." W. Benjamin, "Fragmente vermischten Inhalts", Gesammelte Schriften VI, p. 71.
} 
de mon geste et j'ai honte. II est certain que ma honte n'est pas réflexive, car la présence d'autrui à ma conscience, fût-ce à la manière d'un catalyseur, est incompatible avec l'attitude réflexive: dans le champ de ma réflexion je ne puis jamais rencontrer que la conscience qui est mienne. Or autrui est le médiateur indispensable entre moi et moi-même: j'ai honte de moi tel que j'apparais à autrui. [...] la honte est, par nature, reconnaissance. Je reconnais que je suis comme autrui me voit. [...] La notion même de vulgarité implique d'ailleurs une relation intermonadique. On n'est pas vulgaire tout seul. ${ }^{537}$

Da mesma forma como Sartre considera a vergonha como reconhecimento, como uma relação necessária ao outro (como uma apreensão de si mediada pelo ser-para-outro, pelo ser visto por outro), podemos dizer que a seriedade (como posição diante do sofrimento alheio, por exemplo) é também, no limite, reconhecimento - e tal como aquele "impulso moral”, no caso por exemplo do horror à tortura, também a vergonha (e aquilo que impele à seriedade) ocorre como um impulso corporal: "la honte est un frisson immédiat qui me parcourt de la tête aux pieds sans aucune préparation discursive." ${ }^{, 538} \mathrm{Em}$ ambos os casos trata-se de um sentimento que surge na implicação com o outro, ou ainda, dito de outra forma, na relação do indivíduo com o mundo. Apesar da imagem recorrente da "torre de marfim" em se tratando de Adorno, como se autonomia fosse sinônimo de solipsismo, sem o outro não existe seriedade, só se é sério por causa do outro - mesmo que esse outro não seja uma outra consciência, como exige Sartre (e Hegel), tal como no exemplo adorniano de se estar diante da natureza. De todo modo, trata-se de um outro que sofre. Mas a situação séria, o "contexto universal de culpa", é um nexo social - a totalidade social como o pecado original secularizado. ${ }^{539}$ Por isso ela não pode ser absolutizada como condição da existência humana, como faz Sartre. Esse mesmo "contexto universal de culpa" adorniano é análogo a algo que Sartre chama de "vergonha original" 540 , que seria própria à condição do homem "lançado" no mundo (nesse caso, retomando a Geworfenheit heideggeriana):

La honte n'est, pareillement, que le sentiment originel d'avoir mon être dehors, engagé dans un autre être et, comme tel, sans défense aucune [...]. La honte est sentiment de chutte originelle, non $\mathrm{du}$ fait que $\mathrm{j}$ 'aurais commis telle ou telle faute, mais

\footnotetext{
${ }^{537}$ Sartre, L'être et le néant, p. 260.

${ }^{538}$ Sartre, L'être et le néant, p. 260 .

${ }^{539}$ Como explicado acima.

${ }^{540}$ Para Benjamin, a culpa é o nexo da história: “A categoria suprema da história do mundo, que garante a univocidade dos acontecimentos, é a culpa. Todo momento da história mundial é culpado e inculpa [verschuldet und verschuldend]." Gesammelte Schriften VI, p. 92
} 
simplement du fait que je suis 'tombé' dans le monde, au milieu des choses, et que j'ai besoin de la médiation d'autrui pour être ce que je suis. La pudeur et, en particulier, la crainte d'être surpris en état de nudité ne sont qu'une spécification de la honte originelle: le corps symbolise ici notre objectité sans défense. Se vêtir, c'est dissimuler son objectité, c'est réclamer le droit de voir sans être vu, c'est-à-dire d'être pur sujet. C'est pourquoi le symbole biblique de la chute, après le péché originel, c'est le fait qu'Adam et Eve 'connaissent qu'ils sont nus'. ${ }^{541}$

Se a vergonha, para Sartre, é condição desse "être dehors" da consciência, para Adorno ela é algo que clama pela sua superação. A "vergonha na participação da injustiça universal" ${ }^{542}$ deseja o fim da injustiça universal no "sonho de uma existência sem vergonha [Schande]". ${ }^{543}$ Para evitar equívocos, é importante dizer que Adorno tampouco faz uma defesa da violência da imposição moral por meio da vergonha (que se torna inseparável da estrutura repressiva da sociedade que vai contra a satisfação pulsional dos indivíduos concretos): "A brutalidade exercida contra os homens se reproduz neles; aqueles que são expostos à vergonha não são educados, mas levados à regressão, rebarbarizados. Não há mais como abafar a intelecção própria à psicanálise de que os mecanismos civilizatórios de repressão transformam a libido em agressão anticivilizatória. [grifo meu]"544

Tampouco a seriedade deve ser permanente, pelo contrário, visto que ela é exigida por uma situação que deve ser transformada. E isso vale mesmo para o cinza, o negro e o silêncio na arte, que não devem transfigurados em valores estéticos eternos: "Talvez os jogos de sonoridades e de cores correntes reajam ao empobrecimento que semelhante ideal traz consigo; pode ser que a arte, um dia, sem traição, venha abolir esse mandamento, como Brecht pôde perceber, ao escrever os versos: 'Que tempos são estes em que falar de árvores é quase um crime, pois implica silenciar sobre tantas barbaridades!" 545 Ou seja, não se trata também de evocar um luto perpétuo. Também Günther Anders faz apelo às palavras hiper-afiadas do exagero como alerta (que é também um condensamento da seriedade enquanto tensão e exigência de atenção $e$

\footnotetext{
${ }^{541}$ Sartre, L'être et le néant, p. 328.

${ }^{542}$ MM, p. 143.

${ }^{543}$ MM, p. 82 (tradução modificada).

${ }^{544}$ DN, p. 279.

${ }^{545}$ TE, p. 68 (tradução modificada).
} 
lucidez, oposta à descontração relaxada da desimportância), mas somente porque "o tempo da simplicidade, nós ainda não o alcançamos"

\section{Fome: valor de uso e sofrimento}

A única delicadeza se encontraria no mais grosseiro: que ninguém mais precisasse passar fome.

Adorno

A existência vergonhosa e culpada em um mundo onde reina o horror do sofrimento coloca, de antemão, o problema da satisfação (visto que ela aparece como bloqueada). Quando Adorno diz que "o esquema da capacidade de gozo não perturbada" passa pela proibição do conhecimento do sofrimento, isso significa que a felicidade, objetivamente, é incompatível com a produção massiva de sofrimento social e torna-se concreta na liberdade realizada socialmente: "Não somente a possibilidade objetiva também a capacidade subjetiva de felicidade somente se dá na liberdade. ${ }^{547}$ Ou seja, ao mesmo tempo em que "toda felicidade visa ao preenchimento sensível e conquista nesse preenchimento sua objetividade", 548 o que passa pela sensibilidade do indivíduo concreto e suas satisfações, o bloqueio da satisfação alheia (isto é, o sofrimento do outro), tornase um sofrimento meu, de modo a tornar objetivamente impossível a felicidade individual

\footnotetext{
${ }^{546}$ Günther Anders, Antiquiertheit des Menschen I, p. 237. É importante notar que é contra todo adiamento da satisfação que se voltará, no 1968 francês, as reconfigurações da implicação política do sujeito. Foucault, no prefácio ao Anti-Édipo de Deleuze e Guattari que ele intitula como "Introdução a uma vida não fascista", diz: "Não imaginem que é preciso ser triste para ser militante, mesmo se o que se combate é abominável. É a ligação do desejo com a realidade (e não sua fuga nas formas da representação) que possui uma força revolucionária." Foucault, "Introdução a uma vida não fascista". O teor de verdade aqui é o reconhecimento de que é necessário formular uma prática política e uma ética para a "esquerda sem futuro" (T. J. Clark), para as lutas na "era das expectativas descrescentes" (P. Arantes), de modo que seria injusto vincular, ao menos nesse caso, essa tentativa de aproximação entre desejo e política (e a recusa das "paixões tristes") ao gozo cínico e indiferente. De todo modo, abriu-se mão daquela felicidade universal utópica por vir que pertence às grandes expectativas históricas da modernidade, cujas promessas revelaram-se como mentiras. No caso brasileiro, a "perda de seriedade" que atesta a desistência da espera e um reconhecimento de que esse futuro não virá é reconhecível na passagem da dimensão trágica do Cinema Novo até o Terra em Transe de 1967 para o espírito escrachado e hedonista (embora melancólico) do Cinema Marginal e do tropicalismo pós-AI 5, por exemplo em Bang Bang (1971) de Andrea Tonacci. Cf. Ismail Xavier, Alegorias do subdesenvolvimento e Paulo Arantes, Da noite para o dia.

${ }^{547}$ MM, p. 87. A ideia de uma objetividade da felicidade, em Adorno (assim como a relação entre prazer e verdade, em Marcuse), vai contra a concepção freudiana de que "a felicidade é algo inteiramente subjetivo". Freud, O Mal-Estar na Civilização, p. 33.

${ }^{548}$ DN, p. 173.
} 
em meio à infelicidade universal. Ou seja, trazer o problema da felicidade para o âmbito da reflexão moral não significa a formulação de uma ética individual voltada para "ser feliz" (independentemente do estado de coisas), mas sim a tranformação de um problema da ética clássica em uma questão eminentemente política. A politização da felicidade, aliás, é algo que remete ao século XVIII, quando, às vésperas da Revolução Francesa, a felicidade torna-se bandeira política. Para Diderot, por exemplo, a felicidade é dever: "Il n'y a qu'une vertu, la justice; qu'un devoir, de se rendre heureux; qu'un corollaire, de ne pas se surfaire la vie, et de ne pas craindre la mort." ${ }^{, 549}$ Como diz Bloch, o materialismo do século XVIII foi o "pé-de-cabra da Revolução". Na época, segundo o historiador Robert Mauzi em L'Idee du Bonheur au XVIII siècle, são publicados cerca de 50 escritos intitulados Essai sur le bonheur ou Traité du bonheur. ${ }^{550}$ A tradição socialista dá continuidade a isso na medida em que se busca, nos termos de Marx, "derrubar todas as relações nas quais o homem é um ser humilhado, escravizado, abandonado, desprezível." ${ }^{551}$ A exigência de que as condições materiais da existência sejam transformadas une-se à experiência sensível do sofrimento e ao desejo frustrado de felicidade.

Tendo isso em vista, Marcuse chega a observar uma convergência entre o princípio do hedonismo e o horizonte da teoria crítica: “Com o princípio do hedonismo, a exigência de liberdade do indivíduo - numa forma abstrata e não desenvolvida - é levada ao domínio das relações materiais da vida. Na medida em que o protesto materialista do hedonismo preserva uma parte antes proscrita da libertação humana, ele se vincula ao interesse da teoria crítica." ${ }^{552}$ Se a teoria crítica em sua seriedade parece, por um lado, secularizar a ascese cristã na culpa (na qual a satisfação e o prazer são vetados), ela, por outro lado, em seu materialismo das necessidades e das pulsões, mantém uma afinidade com o hedonismo. Isso se explica pelo fato de que onde há sofrimento, onde a satisfação aparece bloqueada, há horizonte de satisfação e de fim do sofrimento (que deve se tornar real no mundo terreno, e não no além-mundo cristão). Algo que certamente vai na contramão da ética kantiana, que considerava como patológica toda determinação não-racional da ação (como, por exemplo, aquilo que visa a satisfação pulsional). Tampouco o prazer e a felicidade poderiam ser colocados como

\footnotetext{
${ }^{549}$ Denis Diderot, Élements de physiologie. Agradeço a Daniel Garroux pela referência.

${ }^{550}$ Cf. Alfred Schmidt, "Zum Begriff des Glücks in der materialistischen Philosophie" in Drei Studien über Materialismus. Schopenhauer. Horkheimer. Glücksproblem., p. 154

${ }_{552}^{551}$ MEW 1, p. 385.

${ }^{552}$ Herbert Marcuse, "Para a Crítica do Hedonismo" in Cultura e Sociedade, p. 163.
} 
finalidade de uma ação moral, de modo que, para Kant, "a lei moral não promete, ela mesma, nenhuma felicidade" ${ }^{553}$. Se em Marx essa centralidade da sensibilidade aparecia como herança de um materialismo feuerbachiano ${ }^{554}$, entre os frankfurtianos isso já vinha filtrado sobretudo pela psicanálise de Freud, que em $O$ mal-estar na civilização dizia:

[...] o que revela a própria conduta dos homens acerca da finalidade e intenção de sua vida, o que pedem eles da vida e desejam nela alcançar? É difícil não acertar a resposta: eles buscam a felicidade, querem se tornar e permanecer felizes. Essa busca tem dois lados, uma meta positiva e uma negativa; quer a ausência de dor e desprazer e, por outro lado, a vivência de fortes prazeres. 555

Ainda na Dialética Negativa, esse horizonte pulsional calcado na experiência concreta de sofrimento exerce uma função central na medida em que ela porta uma negatividade (a dor se torna, para Adorno, "motor do pensamento dialético",556) e aponta para aquilo que não está aí: "O momento corporal anuncia ao conhecimento que o sofrimento não deve ser, que ele deve mudar. 'A dor diz: pereça.' Por isso, o especificamente materialista converge com aquilo que é crítico, com a práxis socialmente transformadora." ${ }^{, 557}$ E se podemos falar de um horizonte da pulsão, que diz que as coisas devem mudar, não é por acaso que em Bloch o sofrimento da privação transforma-se em "afeto expectante": "O impulso básico da fome precisa ser analisado aqui, na maneira como ele avança para a privação negada e, portanto, para o principal afeto expectante: a esperança." ${ }^{558}$ Se o título do livro de Bloch O Princípio Esperança pode dar a impressão de se tratar de um consolo ingênuo descabido em uma situação desesperadora (principalmente depois que a comercialização da palavra "esperança" fez ela entrar em descrédito para espíritos mais exigentes), devemos ter em mente que o livro pode ser lido, objetivamente, como uma teoria do sujeito, na medida em que o livro trata menos de situações que "trazem esperança", mas é antes uma análise dos afetos e das tendências

\footnotetext{
${ }^{553}$ Immanuel Kant, Crítica da razão prática, p. 167.

${ }^{554}$ Nas palavras do jovem Marx: "O homem, enquanto um ser objetivo sensível, é portanto um ser que sofre [leidendes], e enquanto um ser que sente o seu sofrimento, ele é um ser passional [leidenschaftliches]. $\mathrm{O}$ ardor [Leidenschaft], a paixão [Passion] é a força essencial do homem que energicamente ambiciona seu objeto." (MEGA 1.2, p. 409)

${ }_{555}^{55}$ Freud, O Mal-estar na Civilização, p. 19

${ }^{556}$ DN, p. 173. De forma semelhante, falando sobre a Bedürfnis, Bloch diz: "A sua necessidade de suprir a demanda é o óleo na lâmpada da história.” PE, p. 71.

${ }^{557}$ DN, p. 173.

${ }^{558}$ PE, p. 21.
} 
inerentes ao sujeito ${ }^{559}$ (que encontra seu lado objetivo na realidade onde o futuro é fermentado). Assim como Adorno vincula sofrimento e negatividade, isto é, vincula a dor a um não dever ser do presente, também Bloch, centrado no impulso da fome ${ }^{560}$ (que ele caracteriza como "o mais fundamental instinto de auto-preservação"), remete essa dimensão pulsional a um "não ao ruim existente". Mas da mesma forma como Adorno falava da "dor elevada ao âmbito do conceito", Bloch fala da "fome instruida" (reiterando a centralidade do pensamento):

${ }^{559}$ Tais desejos seriam portanto, assim como em Freud, uma constante antropológica: "O desejo de ver as coisas melhorarem não adormece. Nunca nos livramos do desejo, ou então nos livramos apenas ilusoriamente. [...] Não é hora de desistir dos desejos. Os que sofrem privação sequer pensam nisso: eles sonham que seus desejos um dia serão realizados." PE, p. 79. Bloch certamente vai na contramão de uma ideia (que, de certa forma, persiste no pessimismo freudiano) de um mau infinito do desejo, tal como formulada por Schopenhauer: "A essência do ser humano consiste em sua vontade se esforçar, ser satisfeita e de novo se esforçar, incessantemente; sim, sua felicidade e bem-estar é apenas isto: que a transição do desejo para a satisfação, e desta para um novo desejo, ocorra rapidamente, pois a ausência de satisfação é o sofrimento, a ausência de novo desejo é o anseio vazio, languor, tédio [...]". Schopenhauer, O mundo como vontade e como representação, p. 301. Contra a condenação à vida tediosa, o interesse da teoria crítica se mantém fiel ao horizonte do desejo, sintetizado no Zaratustra de Nietzsche, que diz: "A dor diz: passa! Mas todo prazer quer eternidade...” Nietzsche, Assim falou Zaratustra.

${ }^{560}$ Bloch chega ao ponto de, em uma tentativa tão interessante quanto absurda, buscar reformular a teoria freudiana das pulsões substituindo a libido pela fome, em que a fome aparece como uma pulsão "mais baixa", anterior à libido (o que pode dar a impressão de que a pulsão é algo puramente fisiológico, e que estaria menos sujeito a modulações sociais e históricas): “[...] por mais alto que a fome grite, raramente ela é tratada do ponto de vista médico. Essa omissão mostra que a psicanálise trata e sempre tratou apenas de sofredores privilegiados. A preocupação de encontrar alimento era para Freud e seus clientes a mais sem fundamento. $\mathrm{O}$ médico psicanalista e sobretudo seu paciente provêm de um estrato médio que até recentemente não precisou se preocupar muito com o estômago. Entretanto, quando a Viena de Freud se tornou menos despreocupada, abriu-se um consultório psicanalítico para pessoas que haviam tentado suicídio e nele houve oportunidade de se tomar conhecimento de pulsões situadas abaixo da libido, pois mais de noventa por cento de todos os suicídios ocorrem por necessidade econômica e apenas o restante por decepção amorosa (aliás, não recalcada). Contudo, mesmo quando a burguesia de Viena perdeu seus privilégios, uma inscrição continuava pendurada na parede do consultório psicanalítico: QUESTÕES ECONÔMICAS E SOCIAIS NÃO PODERÃO SER TRATADAS NESTE LUGAR. [...] Os conflitos neuróticos do proletariado infelizmente não consistem de algo tão bem situado como a 'fixação da libido em determinadas zonas erógenas' de Freud, ou a 'máscara mal ajustada do caráter' de Adler, ou a 'regressão incompleta aos primórdios' de Jung. A angústia diante da perda de emprego dificilmente será um complexo de castração. É verdade que a psicanálise não pode escapar de às vezes se dar conta da fome e da sede, bem como do interesse da autopreservação. Porém, singularmente, Freud não associa o impulso de autopreservação ao estômago e ao sistema corporal como um todo, no qual ele está ancorado, mas ao conjunto das pulsões tardias do ego - o mesmo que está encarregado da censura moral. [...] Por isso, com toda a reserva e manifesta aversão contra absolutizações, pode-se afirmar o seguinte: a autopreservação - tendo a fome como expressão mais evidente - é a única pulsão fundamental que, dentre as várias, seguramente merece este nome. Ela é a instância última e mais concreta do seu portador. Até o idealista Schiller é obrigado a reconhecer que o mundo é movido "pela fome e pelo amor', colocando, ademais, a fome em primeiro lugar e o amor em segundo.” PE, p. 6870. 
A fome não tem como não se renovar constantemente. Porém, se cresce ininterruptamente, não sendo satisfeita pelo pão assegurado, ela revoluciona. O corpo-eu torna-se rebelde, não vai mais em busca de alimento apenas nos moldes antigos: ele procura modificar a situação que ocasionou o estômago vazio, a cabeça baixa. O não ao ruim existente e o sim ao melhor em suspenso são acolhidos pelos carentes no interesse revolucionário. Em todo caso, é com a fome que esse interesse tem início, a fome transforma-se, como fome instruída, numa força explosiva contra o cárcere da privação. ${ }^{561}$

A fome e as necessidades (ou "carecimentos", no alemão, Bedürfnisse), aos quais ligam-se as questões do sofrimento e da satisfação, são problemas centrais na história do marxismo e também nos debates da teoria crítica. Durante o exílio nos Estados Unidos, ocorre uma discussão sobre a teoria das necessidades, no dia 25 de agosto de 1942, na qual participam Adorno, Horkheimer, Günther Anders, Brecht, Marcuse, Hanns Eisler, Hans Reichenbach e Berthold Viertel. ${ }^{562}$ É no contexto dessa discussão que surge o texto "Teses sobre a necessidade" de Adorno. Nesse texto, Adorno formula claramente a relação entre o problema das necessidades e a urgência dos sofrimentos da humanidade que devem ser superados: “A questão da satisfação imediata da necessidade não deve ser colocada segundo os aspectos social e natural, primário e secundário, correto e falso: ela coincide com a questão do sofrimento da esmagadora maioria de todos os seres humanos na Terra." $" 563$ (Lembremos que a própria palavra miséria significa, ao mesmo tempo, sofrimento e pobreza - do mesmo étimo deriva-se comiseração e misericórdia). $\mathrm{O}$ horizonte de felicidade e satisfação torna-se central diante do imenso sofrimento humano produzido por tais carecimentos, que, entretanto, não devem ser pensados no âmbito puramente fisiológico (Adorno visava criticar a separação entre necessidades primeiras, fundamentais e naturais, de um lado, e necessidades criadas, "supérfluas" e sociais, de outro):

A necessidade é uma categoria social. A natureza, a 'pulsão', está contida nela. Os momentos natural e social da necessidade, entretanto, não se deixam distinguir um do outro como secundário e primário, de modo a construir uma hierarquia de satisfações. A fome, concebida como categoria natural, pode ser saciada com gafanhotos e bolos de mosquito, que muitos selvagens apreciam. Pertence à satisfação da fome concreta dos civilizados que eles

\footnotetext{
561 PE, p. 78.

${ }^{562}$ Um protocolo da discussão encontra-se no volume 12 das obras completas de Horkheimer.

563 Adorno, "Teses sobre a necessidade”, p. 233 (tradução modificada).
} 
aceitem comer alguma coisa da qual não sintam nojo, e tanto neste quando em seu contrário está refletida toda a História. ${ }^{564}$

Assim como não se deseja do mesmo modo dentro e fora do capitalismo, também não se sente fome da mesma forma em todas as formações sociais, de modo que, para Adorno, é irrelevante e infrutífera a discussão sobre se as necessidades, a partir das quais as pessoas sofrem, são "naturais" ou "sociais", visto que, a rigor, todas as necessidades são potencialmente mediadas pela forma mercadoria. Marx, ao conceitualizar o valor de uso logo no início d'O Capital, não faz questão de distinguir "as necessidades do estômago" e "as necessidades da fantasia", e evoca, em seus exemplos, o casaco, a bíblia e a aguardente. Também Bloch, com sua teoria das pulsões calcada na fome, reconhece que "mesmo para a fome não há uma estrutura 'natural' da pulsão"565. Analisado em sua dinâmica social, o problema das necessidades se expressa na questão do valor de uso, que, enquanto categoria econômica (tal como analisada por Marx), é fundamental para a reprodução do capital - embora a satisfação das necessidades e o valor de uso sejam um estorvo para o processo de valorização do valor do qual ele gostaria de se livrar. Mesmo a transformação de dinheiro em mercadoria e esta novamente em dinheiro é igualmente um encalhe neste processo que a financeirização e a ficcionalização da produção de valor elimina, transformando a fórmula D-M-D' em D-D', autonomizando-se em relação à produção. $^{566}$

\footnotetext{
${ }^{564}$ Adorno, "Teses sobre a necessidade", p. 229. Adorno se opunha aqui à posição de Marcuse, que buscava distinguir as necessidades entre verdadeiras e falsas, sendo falsas as necessidades que "trabalham contra a emancipação": "A distinção entre necessidades verdadeiras e falsas é uma das mais difíceis e naturalmente não pode ser verificada 'cientificamente'. Antes de mais nada, a distinção é válida negativamente, na medida em que se pode mostrar que os homens contraíram necessidades que são prejudiciais, que retardam um maior desenvolvimento humano, que retardam a emancipação dos homens, quando não os tornam impossíveis por um largo período. Delas faz parte, por exemplo, - e aqui evidentemente falo apenas dos países industriais altamente desenvolvidos, a situação é essencialmente diferente no Terceiro Mundo - a necessidade, que já se tornou impe- riosa, de, a cada ano, ou a cada dois anos comprar um carro novo, ou a necessidade de comprar um aparelho de televisão maior ou mais sofisticado, a necessidade de ficar sentado durante horas na frente desse aparelho de televisão, a necessidade de comprar todas as mercadorias que hoje são vistas como símbolos de status. São necessidades negativas, que satisfazem de fato uma necessidade que se tornou real, mas ao satisfazê-la retardam a emancipação do homem do trabalho alienado, de todo o sistema de valores do capitalismo e trabalham contra essa emancipação." H. Marcuse apud Isabel Loureiro, "Herbert Marcuse anticapitalismo e emancipação", p. 16.

${ }^{565}$ PE, p. 71.

${ }^{566}$ Embora não seja o caso de desenvolver aqui, é importante notar que (como apontam estudiosos da crise hoje) tal dessubstancialização, paralela ao novo primado da financeirização como decorrente da crise do trabalho, pode ocorrer mesmo quando há D-M-D', isto é, passar pelo âmbito da produção de coisas não é garantia de produção real de valor, uma vez que o que está
} 
Ao mesmo tempo em que Adorno vê no valor de uso o "inefável da utopia"567, ele reconhece que não é possível pensar o valor de uso de forma separada do valor (que, substancialmente, depende de relações sociais calcadas no fetiche da mercadoria), apesar de ele apresentar-se de forma separada ${ }^{568}$. Ou melhor, o caráter isolado do problema das satisfações é posto pela sociabilidade capitalista: "Somente quando o pão precisa ser lucrativo para que ele seja produzido coloca-se separadamente a questão sobre seu uso para o consumidor." 569 Sendo assim, quando o materialismo pensa a partir do "primado da produção material da vida", isso não significa que tal "primado" seja algo da natureza humana, portanto, não é algo que deve ser projetado para todas as formas de sociedade já existentes, muito menos para a futura. Não por outra razão que, segundo Adorno, o materialismo visa superar as condições sociais que justificam o materialismo, e não legitimá-lo como ciência válida desde sempre e para todo o sempre: "O ponto de fuga do materialismo histórico seria a sua própria suspensão, a liberação do espírito do primado das necessidades materiais no estado de sua realização." 570 Wolfgang Pohrt, em sua Teoria do valor de uso, escreve algo semelhante: "Não mais a eliminação da fome está na ordem do dia, mas a eliminação das relações, sob as quais a eliminação da fome ocupa e marca toda a vida humana." ${ }^{, 571}$ Por isso, como diz Adorno, uma vez que a produção fosse efetivamente voltada para a satisfação das necessidades (mesmo para as necessidades forjadas pelo capitalismo), a própria ideia de produzir para satisfazer as necessidades seria abolida, visto que ela pertence ao mundo em que "o pão precisa ser lucrativo para que ele seja produzido" (mesmo que ele seja subsidiado em uma situação de produção "planejada" e deficitária). Pois, justamente, no mundo regido pela lógica da valorização e pela medida do trabalho abstrato (e pela compulsão ao trabalho), o concreto

determinando os preços e possibilitando a acumulação é o próprio mercado financeiro, ou seja, a bolha, e não a produção real de valor.

567 '“[...] o fato de se precisar daquilo que não pode ser subsumido à identidade - o valor de uso segundo a terminologia marxista - para que a vida em geral perdure, até mesmo sob as relações de produção dominantes, é o inefável da utopia.” DN, p. 18

${ }^{568}$ No curso Fragen der Dialektik, por exemplo, Adorno diz explicitamente: “[...] No valor de uso, ou seja, naquilo que os homens têm das coisas, esconde-se sempre é claro já também toda a sociedade, e nessa medida, ali já está de forma imanente também o princípio da troca. Ou seja, com isso eu só quero dizer que todas as tentativas de isolar abstratamente [auszuabstrahieren] um valor de uso por assim dizer puro, que corresponderia de forma imediata às necessidades [Bedürfnissen] da natureza humana, não funcionam, pois essa natureza simplesmente não se permite separar das relações sociais [...]." Adorno, Fragen der Dialektik, Vo 9208, TWAA.

${ }_{569}$ Wolfgang Pohrt, Theorie des Gebrauchswertes, p. 47.

${ }^{570}$ DN, p. 176.

${ }^{571}$ Wolfgang Pohrt, Theorie des Gebrauchswertes, p. 87. 
das satisfações é posto como um momento separado da reprodução social (mas que produz uma unidade - por isso Adorno diz que "a sociedade sem classes [...] supera [aufhebt] não apenas o antagonismo burguês de produção e consumo, mas também sua unidade burguesa." ${ }^{572}$ ). Dito de outra forma: assim como o valor de uso aparece como momento necessário para a realização do valor (o valor de uso é “a forma de aparição de seu contrário, do valor" ${ }^{\circledR 73}$, diz Marx), a necessidade de satisfazer as necessidades é parte central da dominação.

A exigência de produção apenas para satisfazer necessidades pertence ela mesma à pré-história, a um mundo em que se produz não para as necessidades, mas para o lucro e para o estabelecimento da dominação, e onde vigora, por isso, a escassez. Se esta desaparecer, logo a relação entre necessidade e satisfação se alterará. Na sociedade capitalista, produzir para a necessidade em sua forma mediada e, assim, fixada pelo mercado é um dos principais meios de forçar os seres humanos a fazer o que lhes é imposto. ${ }^{574}$

A centralidade da fome na sociedade da escassez (mesmo ali onde há abundância) é parte constituinte da "história natural", isto é, de uma natureza histórica e de uma história naturalizada. Nesse sentido, a superação da fome é a superação da sociedade que dá prosseguimento ao estado de natureza do "devorar e ser devorado" "575, da violência animal transformada em razão instrumental - e coincide com a superação da situação em que a superação da fome organiza a sociedade. Isso persiste mesmo em uma situação onde a satisfação das necessidades parece ter se realizado (como dominação, por certo), a saber, nas sociedades afluentes do pós-guerra (e também, por um certo período, na União Soviética). Já nesse texto de 1942, Adorno apontava para "uma tendência real do capitalismo tardio" que significava o "bloqueio da revolução pela sociedade total"576. Essa preocupação era central para Marcuse, que pensava justamente sobre o definhamento do desejo de emancipação em uma situação que produz uma satisfação repressiva das necessidades básicas. ${ }^{577}$ Também Günther Anders falava de uma "falta de

\footnotetext{
${ }^{572}$ Adorno, "Teses sobre a necessidade", p. 234.

${ }^{573}$ MEW 23/70.

574 Adorno, "Teses sobre a necessidade", p. 234.

575 "A história humana, a história do domínio progressivo da natureza, dá prosseguimento à história insconsciente da natureza, do devorar e do ser devorado." DN, p. 294

${ }^{576}$ Adorno, "Teses sobre a necessidade", p. 231

${ }^{577} \mathrm{O}$ aluno de Adorno e militante da SDS Hans-Jürgen Krahl sintetiza a posição de Marcuse: "No centro da teoria marcuseana da revolução está a questão: como pode se desenvolver a necessidade [Bedürfnis] de emancipação sob as condições de uma satisfação repressiva das necessidades materiais elementares? Como as necessidades de um reino da liberdade, da paz e da felicidade
} 
falta [Mangel an Mangel]": "Nós vivemos em um mundo no qual tudo nos é apresentado, tudo nos é presente, em um mundo sem falta. Entretanto, o processo que nos colocou nessa situação era dialético: quanto menos nos falta [mangelt], mais carentes [mangelhaft] nós mesmos nos tornamos." ${ }^{, 578}$ É evidente que, retrospectivamente, tal debate soa longínquo no passado, visto que, se durante os "trinta gloriosos" do capitalismo parecia estar no horizonte que o desenvolvimento da sociedade industrial iria acabar com a escassez e a fome, pode-se reconhecer hoje que a pobreza extrema e a fome não só não foram superadas na periferia do mundo (onde a gestão governamental da fome - e dos corpos vulneráveis em geral - é inventada e opera como instrumento de dominação diante das "crises humanitárias" "579), como também na Europa e nos Estados Unidos a pauperização voltou a assombrar tanto os centros urbanos como as áreas rurais.

Trazer o sofrimento socialmente produzido e a questão das necessidades para dentro da reflexão moral significa pensar igualmente o problema da pobreza e sua relação com a moral. Se, do ponto de vista kantiano, a ação que parte das necessidades (e dos sofrimentos) não pode ser moral, então aqueles que mais sofrem necessidades estão mais distantes de realizar uma ação moral. Na Metafísica dos Costumes, Kant diz literalmente: "Adversidades, dor e privação são grandes tentações para a transgressão do dever [...]." Ou seja, os pobres estão, de antemão, mais próximos da imoralidade, e os ricos, que têm suas pulsões mais bem adestradas, são mais propensos a universalizar a máxima de sua própria ação. Ou seja, não se trata de abolir o sociedade de classes que produz pobreza e sofrimento, porém, para Kant, tornar-se um indivíduo rico pode ser um dever, como ele mesmo diz: "Buscar a prosperidade por si mesma não é diretamente um dever; porém, indiretamente pode muito bem sê-lo, a saber, evitar a pobreza, como uma grande tentação para vícios. ${ }^{, 581}$ Em Kant se torna explícita essa relação histórica entre moral e riqueza, uma relação que não escapou a Adorno: ele observa, no aforismo "Espelho da virtude" da Minima Moralia, que "ser bom e ter bens confluem desde o início." 582

podem entrar na consciência das massas e tornar-se fenômeno político, se elas não mais estão ancoradas nas necessidades vitais materiais de eliminar a fome, a carência material e a miséria física?" Hans-Jürgen Krahl, "Fünf Thesen zu Herbert Marcuse als kritischer Theoretiker der Emanzipation". Disponível em: http://www.krahl-briefe.de

${ }_{578}$ Günther Anders, Die atomare Drohung, p. 119.

579 Como vêm mostrando certa sociologia calcada na interpretação foucaultiana do neoliberalismo.

${ }^{580}$ Kant, Metafisica dos Costumes, p. 167.

${ }_{582}^{581}$ Kant, Metafisica dos Costumes, p. 199-200

${ }^{582}$ MM, p. 180-181. 
[...] sabemos que "quanto vale" um homem depende da conta bancária e, no jargão comercial alemão é "bom" o homem que pode pagar. [...] A generosidade nas relações privadas, como alegadamente os ricos podem se permitir, a aura de felicidade que nela repousa e da qual ainda se irradia algo sobre aqueles que admite por perto, tudo isso tem efeito no véu. Eles permanecem simpáticos, the right people, as pessoas melhores, os bons. A riqueza afasta da injustiça direta. $\mathrm{O}$ guarda golpeia com seu cassetete de borracha o grevista, o filho do industrial pode ocasionalmente tomar uísque com o escritor progressista. Conforme todas as exigências da moral privada, por avançadas que sejam, o rico poderia - se pelo menos pudesse - de fato ser melhor do que o pobre. ${ }^{583}$

Esse vínculo entre o bom e o rico (que para Adorno está presente já na ética antiga $^{584}$ ) inverte-se somente no cristianismo - por exemplo, na ideia de que "é mais fácil para um camelo passar pelo buraco de uma agulha do que para um rico chegar ao céu" e de forma mais evidente na tradição franciscana, com o voto de pobreza (o "ideal ascético", segundo Nietzsche) e o imperativo de ajudar os necessitados. Por um lado, há efetivamente uma convergência entre o cristianismo e a tradição à qual a teoria crítica se filia na solidariedade com os pobres, e mesmo Marx reconheceu o momento de verdade da religião ao dizer que "o sofrimento [Elend] religioso é, ao mesmo tempo, expressão do sofrimento real e protesto contra ele." Porém, enquanto "coração de um mundo sem coração" 585 , a religião permanece impotente frente às causas terrenas do sofrimento e funciona como satisfação compensatória. Por isso, continua Marx: "A superação [Aufhebung] da religião enquanto felicidade ilusória do povo é a exigência de sua felicidade real. ${ }^{, 586}$ Por isso, a comiseração deve ser transformada em crítica.

\section{Compaixão, calor, frieza}

\footnotetext{
${ }^{583}$ MM, p. 182.

584 "Desde Homero o uso da fala grega faz convergirem os conceitos do bom e do rico. A kalokagatia, que os humanistas da sociedade moderna celebravam como modelo de harmonia estética-moral, sempre acentuou pesadamente a propriedade, e a Política de Aristóteles confessa sem rebuços a fusão do valor íntimo com o status na definição da nobreza, que seria "riqueza herdada, combinada com excelência'." MM, p. 180. Adorno vincula ainda a virtude do autocontrole com o controle das coisas que se possui: "Bom é aquele que se domina a si mesmo como à sua propriedade: seu ser autônomo é modelado na disposição material.” MM, 181 .

${ }^{585}$ MEW 1, p. 378.

${ }^{586}$ MEW 1, p. 379.
} 
A princípio, essa posição diante do sofrimento alheio, que se torna sofrimento próprio, parece pressupor uma atitude compassiva. Afinal, foi Schopenhauer, o filósofo da compaixão, que escreveu (sobre o compassivo): “[...] esse ser humano reconhece em todos os seres o próprio íntimo, o seu verdadeiro si mesmo e desse modo tem de considerar também os sofrimentos infindos de todos os viventes como se fossem seus: assim, toma para si as dores de todo o mundo; nenhum sofrimento é-lhe estranho.,587 Reconhece-se isto naquela testa franzida do poema de Brecht que sente os sofrimentos da humanidade. Esse motivo é certamente presente em Adorno, que, na Dialética Negativa, constata (com vergonha): "o pudor ordena à filosofia não reprimir a intelecção de Georg Simmel segundo a qual é espantoso o quão pouco os sofrimentos da humanidade são observados na história da filosofia” ${ }^{588}$. Podemos dizer que o marxismo (ou o socialismo em geral) parece compartilhar algo da compaixão com os pobres da tradição cristã, e visto que privação material e sofrimento andam juntos, compaixão com os pobres é sinônimo de compaixão com os que sofrem. Em suas reflexões sobre a força pulsional da fome, Bloch nota que a fome, dentre as privações, é o sofrimento que, por excelência, mais intensamente produz compaixão:

A comiseração [Mitgefühl] por quem está morrendo de fome, de qualquer maneira, é a única difundida, até mesmo a única possível em termos mais amplos. A moça e até mesmo o homem que anseia por amor não provocam compaixão. Em contraposição, a queixa da fome é de fato a mais forte, a única que pode ser apresentada sem rodeios. À desgraça do faminto é dado crédito. Ao revés, até mesmo quem está passando frio, até mesmo o doente, mais ainda o doente de amor, dão a impressão de viverem no luxo. Até a dona-de-casa mais insensível eventualmente esquece o rancor de sua avareza quando o mendigo toma a sopa recebida por caridade. Já aqui, nessa forma de comiseração habitual, ficam evidentes a privação e o desejar que está ligado a ela. O estômago é a primeira lâmpada na qual deve ser derramado o óleo. Seu anseio é preciso, sua pulsão tão inevitável que nem mesmo pode ser recalcada por muito tempo. ${ }^{589}$

\footnotetext{
${ }^{587}$ Schopenhauer, p. 439.

${ }^{588}$ DN, p. 133.

${ }^{589}$ PE, p. 68.
} 
Esse sentimento diante da "desgraça do faminto" impele o sujeito - não é por acaso que o passo rumo à politização de um indivíduo, que implica uma compreensão (racional) do mundo, se inicia frequentemente com uma sensibilização moral diante do sofrimento alheio que ele "toma para si”" (mesmo que não seja ele mesmo aquele que, imediatamente, sofre violência e privação). Este sentimento, enquanto "lei do coração", pode também ser considerado do ponto de vista do protesto moral contra o curso do mundo ${ }^{590}$ tal qual criticado por Hegel (implícito na figura de Rousseau), em que há uma continuidade entre "meus sofrimentos" e os "sofrimentos da humanidade", de forma que se tornam inseparáveis a minha felicidade e a felicidade geral. Há aí um ideal de reconciliação, como aponta Hyppolite (também aqui explicando Hegel): “L'individualisme de Rousseau, puis l'individualisme romantique sont une protestation du coeur contre cette violence faite à l'individualité humaine. Il faut libérer l'homme, ce qui ne signifie pas opposer les hommes les uns aux autres, mais au contraire les réconcilier les uns avec les autres puisque mon bien est le bien de l'humanité." ${ }^{591}$ No caso de Schopenhauer, essa continuidade entre o eu e o outro, que quebra os limites da individuação, é uma forma de amor. Porém, talvez seja necessário fazer uma distinção: quando Adorno, retomando uma expressão de Brecht, fala sobre a "solidariedade com os

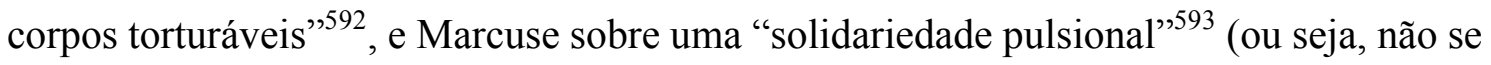
trata, como na doutrina cristã, de um afeto mobilizado por uma consciência de dever), estamos falando da mesma estrutura pulsional a partir da qual o próprio indivíduo sofre e busca prazer. Schopenhauer, entretanto, ao falar sobre o ato de amor que é movido pelo conhecimento do sofrimento alheio, faz uma distinção entre duas formas de amor, a saber, eros (que é, talvez, a forma de amor que de fato interessa à psicanálise), que ele chama de amor-próprio e que está vinculado ao deleite, e agape, que é "amor puro e verdadeiro" - a compaixão:

[...] o que a benevolência, o amor e a nobreza de caráter podem fazer pelos outros é sempre apenas o alívio de seus sofrimentos; conseguintemente, o que os pode mover a bons atos e a obras de amor é sempre e tão somente o CONHECIMENTO DO SOFRIMENTO

\footnotetext{
${ }^{590}$ Como considerado acima.

${ }^{591}$ [grifo meu]. Jean Hyppolite, Génèse..., p. 276.

592 DN, p. 238.

593 "Revolt against false father, teachers, and heroes - solidarity with the wretched of the earth: is there any 'organic' connection between the two facts of the protest? There seems to be an all but instinctual solidarity. The revolt at home against home seems largely impulsive, its targets hard to define: nausea caused by the 'way of life', revolt as a matter of physical and mental hygiene." Marcuse, Eros and civilization, pp. xvi-xvii.
} 
ALHEIO, compreensível imediatamente a partir do próprio sofrimento e posto no mesmo patamar deste. Daí segue-se o

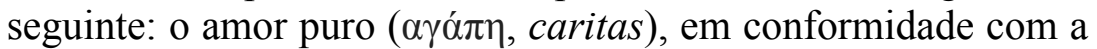
sua natureza, é compaixão; e o sofrimento que ele alivia (ao qual pertence todo desejo insatisfeito) tanto pode ser grande quanto pequeno. Em consequência, não hesitaremos ao contradizer KANT diretamente - que só quer reconhecer toda verdadeira bondade e toda virtude se elas provêm da reflexão abstrata, e em verdade do conceito de dever e imperativo categórico, explanando ele a compaixão sentida como uma fraqueza e de modo algum uma virtude [...] todo amor puro e verdadeiro é compaixão, e todo amor que não é compaixão é amor-próprio.

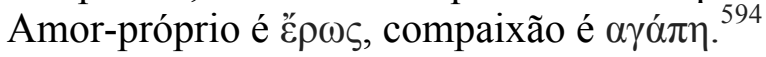

A oposição a Kant permeia todo o texto, pois, de fato, talvez mais até que em Sade e Nietzsche, foi na filosofia kantiana que a crítica à compaixão foi levada às últimas consequências. A recusa a tudo que é heterônomo em relação à determinação racional da vontade implica não só a recusa do prazer (e da eliminação do sofrimento próprio) como fundamento da moral ${ }^{595}$ (que, do ponto de vista cristão, poderia igualmente ser criticado como egoísmo ou hedonismo), mas significa igualmente a recusa do "amor ao próximo" como algo que poderia justificar o "ato bom", visto que seria algo mobilizado pela contingência do afeto. Não é por acaso que Kant fala abertamente de um "dever da apatia", sobre a qual ele diz: "Essa palavra [apatia, FC] ganhou má reputação, como se significasse insensibilidade, por conseguinte, indiferença subjetiva com vistas aos objetos do arbítrio; ela foi tomada por fraqueza. Essa interpretação errônea pode ser evitada ao denominar-se apatia moral aquela ausência de afetos que deve ser distinguida da indiferença [...]." ${ }^{, 596}$ A apatia kantiana, portanto, como ele diz, não é "fraqueza", retomando assim o vínculo clássico entre moral e força (presente na ética de virtudes), nesse caso uma força que é preciso angariar para ir contra a particularidade dos afetos em vista da realização da liberdade, de caráter universal. Mas tal posição, como nota Adorno, com o ideal nietzscheano da dureza: "Em seu desprezo pela compaixão, a razão prática pura concorda com o 'endurece-te a ti mesmo' do antípoda Nietzsche [...]." ${ }^{\text {,597 }}$ Na tradição das virtudes do mundo da guerra e do trabalho, masculino e viril, a compaixão aparece

\footnotetext{
${ }^{594}$ Schopenhauer, O mundo como vontade e representação, p. 436.

${ }^{595} \mathrm{Em}$ seu curso de filosofia moral, Adorno diz: "O verdadeiro ponto central dessa filosofia moral é que, em Kant, de modo bastante curioso, o conceito de heteronomia está ligado ao conceito de Eudaimonismus, da ética da felicidade, ao hedonismo."PM 1, 20/11/1956.

${ }^{596}$ Kant, Metafisica dos Costumes, p. 220.

${ }^{597}$ DN, p. 218.
} 
como "efeminada" (o "dissociado" do valor ${ }^{598}$ ), "moleza" daqueles que não suportam a dor. No capítulo sobre a Juliette de Sade, na Dialética do Esclarecimento, Adorno e Horkheimer escrevem:

A commiseratio é a humanidade em sua figura imediata, mas ao mesmo tempo "mala et inutilis", a saber, o contrário do valor viril que, da virtus romana passando pelos Medici até a efficiency da família Ford, foi sempre a única virtude verdadeiramente burguesa. Efeminada e infantil, eis como Clairwil chama a compaixão, jactando-se de seu "estoicismo", do "repouso das paixões", que lhe permite tudo "fazer e tudo aguentar sem emoção." 599

A dureza viril, como a virtude de "tudo fazer e tudo aguentar" (inerente ao próprio ideal de força como aceitação do mundo sem reclamações), é oposta à compaixão da mesma forma como ela se opõe àquilo que Schopenhauer chamou de "compaixão consigo mesmo", que é o sofrimento sentido, de modo que a virtude da dureza, tanto em Sade quanto em Kant (Kant fala de "firmeza moral" ${ }^{600}$ ), significa bloqueio do sentimento do sofrimento - que, enquanto demanda de adaptação, significa também não chorar. Afinal, segundo Schopenhauer:

O CHORO é, por conseguinte, COMPAIXÃO CONSIGO MESMO ou a compaixão que retorna ao seu ponto de partida. É, pois, condicionado tanto pela capacidade de amar e compadecer-se quanto pela fantasia: eis por que pessoas duras de coração ou sem fantasia não choram facilmente, e o choro é sempre visto como signo de certo grau de bondade de caráter, e desarma a cólera $[\ldots] .{ }^{601}$

O ideal burguês da dureza consigo mesmo (que se transforma, ao fim e ao cabo, em dureza com os outros) foi abordado por Adorno ao tratar de um assunto em que tais reflexões morais ganham concretude, a saber, educação. No ensaio Educação após Auschwitz, a ideia pedagógica de conquistar uma dureza interior aparece como algo que está ligado à formação de indivíduos indiferentes à dor, e, assim, potencialmente sádicos:

\footnotetext{
${ }^{598}$ Roswitha Scholz, O valor é o homem.

${ }^{599}$ Adorno; Horkheimer, Dialética do Esclarecimento.

${ }^{600}$ Kant fala ora de uma firmeza da virtude, ora define a própria virtude como fizmeza: "A verdadeira firmeza da virtude é o ânimo tranquilo com uma sólida e refletida decisão de pôr sua lei em exercício. Esse é o estado de saúde na vida moral [...]." Kant, Metafisica dos Costumes, p. 220-221 Em outra passagem: "Virtude significa uma firmeza moral da vontade. [...] essa firmeza moral, enquanto bravura (fortitudo moralis), constitui-se como a maior e a única verdadeira honra guerreira do homem; ela também é denominada a genuína sabedoria, a saber, a sabedoria prática [...].” Ibid, p. 216-217.

${ }^{601}$ Schopenhauer, O mundo como vontade e representação, p. 437.
} 
A ideia de que a virilidade consiste na capacidade de aguentar até o limite da resistência foi, durante muito tempo, a imagem encobridora de um masoquismo que - como foi demonstrado pela psicologia - tão facilmente se funde com o sadismo. A enaltecida dureza que a educação deve conseguir significa, pura e simplesmente, indiferença à dor. A propósito, não há muita distinção entre a dor própria e a alheia. Aquele que é duro consigo mesmo se arroga o direito de ser duro também com os demais e se vinga neles da dor que não pode manifestar, que teve que reprimir. ${ }^{602}$

A partir de um motivo evidentemente schopenhaueriano (no caso, a afinidade entre dor própria e alheia), Adorno observa que a dimensão pretensamente moral de uma renúncia pulsional (como no caso da resistência à dor) se transforma em seu contrário, a saber, na negação da moral e na violência sádica. Aliás, não era outra a intenção de Adorno e Horkheimer ao compararem Kant com Sade na Dialética do Esclarecimento e ao considerarem as interversões entre formalismo moral e perversão.

Entretanto, a questão sobre aguentar a dor reaparece, em outra chave, na tortura - ainda como continuação da ideia de capacidade de resistência (física) na situação real de enfrentamento (visto que não delatar seria, a princípio, ainda parte de um "combate", momento final da resistência). Ainda em seu ensaio sobre a tortura, Améry escreve: "É tão difícil livrar-se da tortura quanto da questão sobre as possibilidades e os limites da capacidade de resistência. Já conversei a respeito com muitos companheiros e procurei reconstituir diversas experiências. É verdade que os que são corajosos resistem à tortura? Tenho dúvidas." Ele relembra diversos casos de resistentes, desde militantes que eram considerados heróis e que delataram todo mundo ${ }^{603}$, até Jean Moulin, que foi presidente do Conselho Nacional da Resistência Francesa: "Se houvesse falado, toda a Resistência teria sido desarticulada. Aguentou até a morte e não revelou nenhum nome.” Entretanto, a questão permanece insolúvel para Améry: “Onde reside a força? E a debilidade? Não sei. Ninguém sabe. Tampouco alguém foi capaz de traçar os limites bem nítidos que

\footnotetext{
${ }^{602}$ [grifo meu] Adorno, "Educação após Auschwitz", p. 114.

603 "Houve o caso do jovem aristocrata belga que se havia convertido ao comunismo e era considerado um herói, havendo combatido na Guerra Civil Espanhola do lado dos republicanos. Quando foi torturado em Breendonk, porém, 'abriu tudo', como se diz na gíria dos bandidos. Como dispunha de muita informação, entregou toda a rede da sua organização. E não ficou por aí esse homem corajoso. Acompanhava os esbirros da Gestapo às casas de seus companheiros e, com grande energia, exortava-os a confessar tudo, pois esse era o preço que estava disposto a pagar para livrar-se da tortura. E sei de outro caso, de um revolucionário profissional búlgaro que se calou teimosamente; a tortura que sofreu, se comparada à minha, faria com que esta parecesse apenas um esporte violento." Jean Améry, Além do crime e castigo, p. 73
} 
separariam a chamada capacidade de resistência 'moral' e a capacidade de resistência 'física', ambas entre aspas, diante da dor." ${ }^{604}$ Por fim, apesar de ele não desejar correr "o risco de perdoar qualquer autocomiseração e covardia física", diante da tortura já não faz sentido vincular coragem à resistência à dor. Essa questão reaparece na Dialética Negativa, quando Adorno escreve que "não se pode profetizar de ninguém, nem mesmo do mais íntegro dos homens, como ele se comportaria diante da tortura [...]. ${ }^{, 605}$ Ao fim e ao cabo, no mundo burguês do trabalho, "aguentar a dor" torna-se sinônimo de adaptação social por meio da resignação pulsional, como escrevia Marcuse: "In the long run, the question is only how much resignation the individual can bear without breaking up.",606 Há uma afinidade estrutural entre o elogio da frieza e da dureza como virtude moral e o elogio do mundo frio e duro que endurece os sujeitos - Adorno e Horkheimer já haviam escrito na Dialética do Esclarecimento: "O pathos da frieza de ânimo justifica o mundo que a torna necessária.",607

No contexto do forte kantismo na Alemanha, observa-se uma curiosa reabilitação da compaixão, ainda no interior do marxismo, também via Schopenhauer ${ }^{608}$. O socialista Franz Mehring, que, assim como Lukacs e Kautsky, havia criticado a "apologia indireta" da metafísica burguesa schopenhaueriana, publica em 1909 o artigo Zurück auf Schopenhauer!, com exclamação e tudo. Ali testemunha-se uma verdadeira reação ao kantismo, a ponto de Mehring encerrar seu texto categoricamente: "Summa Summarum: o retorno a Kant é uma coisa tão altamente confusa e filistina que, frente a ela, mesmo o brado 'De volta a Schopenhauer!' já quase soa como uma trompetada revolucionária.",609 A ética schopenhaueriana da compaixão, frente à apatia do racionalismo moral kantiano, mostrava-se de alto interesse para os socialistas: "Schopenhauer deu um passo decisivo para além de Kant na medida em que ele declarou a compaixão como fundamento da moral., 610

Porém, nada mais longe dos interesses de Adorno que "declarar a compaixão como fundamento da moral”, sobretudo pelo fato de a compaixão, por si só, manter

\footnotetext{
${ }^{604}$ Idem.

${ }^{605}$ DN, p. 190.

${ }^{606}$ Marcuse, Eros and civilization, p. 246.

${ }^{607}$ Adorno; Horkheimer, Dialética do Esclarecimento.

608 Acompanho aqui Ludger Lütkehaus em seu estudo Schopenhauer: Metaphysischer Pessimismus und "soziale Frage" e na coletânea de textos que organizou junto com Hans Ebeling em Schopenhauer und Marx: Philosophie des Elends - Elend der Philosophie?.

${ }^{609}$ Franz Mehring, Zurück auf Schopenhauer! in Die Neue Zeit, 27. Jg. 1908/09, Zweiter Band, pp. $625-628$

${ }^{610}$ Idem.
} 
inalterado o estado de coisas. Marx, em 1846, já desdenhava também dos apelos cristãos ao amor contra o ódio tendo em vista a impotência do amor diante da força das coisas e de sua incapacidade de produzir a "energia ativa necessária" para as transformações da sociedade:

Em vista da realidade nefasta, do ódio, preconizava-se o reino do amor. (...) Porém, se a experiência ensina que, em 1800 anos, esse amor não se tornou operante, que ele não foi capaz de transformar as relações sociais, de fundar o seu reino, então resulta disso claramente que esse amor, que não conseguiu vencer o ódio, tampouco concede a energia ativa necessária para reformas sociais. Esse amor perde-se em frases sentimentais, através das quais nenhuma condição real, fática é eliminada; ele exaure o homem com o enorme mingau sentimental com que o alimenta. É a privação que concede força ao homem; quem tem de ajudarse, ajuda-se. (...) Essa obrigatoriedade férrea provoca a difusão das pretensões socialistas e lhe traz adeptos operantes, e é ela que abrirá caminho para as reformas socialistas mediante a transformação das atuais relações de troca mais do que todo o amor que arde em todos os corações sensíveis do mundo. ${ }^{611}$

Marx visa, aqui, calcar o impulso à solidariedade, imprescindível à política revolucionária, não no amor, mas na "obrigatoriedade férrea" da necessidade: "é a privação que concede força ao homem; quem tem de ajudar-se, ajuda-se." Não se trata, evidentemente, de rebaixar o amor - o ponto é que, para Marx, o amor é incapaz de se transformar em um afeto político (para usar uma linguagem contemporânea). Também Adorno, para quem o sofrimento ocupa um lugar central nas reflexões sobre a moral e sobre a sociedade, e que critica com tanta veemência o ideal da dureza (comum a Kant e Nietzsche), dá razão à crítica nietzscheana da ética da compaixão, tal como ele diz em aula:

A crítica de Nietzsche à moral da compaixão tem sua razão, pois o conceito de compaixão tacitamente legitima e mantém o estado negativo de impotência no qual se encontra o objeto do compadecimento. Ele não coloca em questão a transformação do estado no qual a compaixão é produzida, mas este estado é hipostasiado e aceito como algo eterno, como em Schopenhauer, que incorpora este estado na moral tornando-o seu próprio fundamento. Podemos então com razão dizer que na compaixão que se sente por uma pessoa há também sempre um momento de injustiça frente a ela, pois ao mesmo tempo experimenta-se na

${ }^{611}$ Marx, "Rundschreiben gegen H. Kriege, einen Anhänger Feuerbachs” apud Bloch PE p. 269. 
compaixão também a impotência e o caráter de aparência do ato de compaixão. ${ }^{612}$

O momento "compassivo" da teoria crítica, que busca trazer para sua dinâmica interna os sofrimentos da humanidade, deve ser considerado não como um ato de amor frente às vítimas das violências do mundo, mas é, digamos assim, um ponto de partida. Quando Adorno dizia que a dor anuncia ao pensamento que ela não deve ser, há ainda aqui uma centralidade do intelecto na mediada em que a dor deve fazer pensar. Era a isso a que Bloch se referia da complementaridade necessária entre a "corrente quente" e a "corrente fria" do marxismo. Variando o ditado alemão "Not lehrt beten" [a necessidade ensina a rezar], ele dizia: "Not lehrt denken" [a necessidade ensina a pensar] ${ }^{613}$. Se entre os frankfurtianos o sofrimento aparece como "motor da dialética", é porque a dor, a falta e os desejos aparecem sob a forma da negatividade, mas podemos dizer que tal motivo (anti-cartesiano, por certo) de fundar a força e o movimento do pensamento (que, nesse caso, torna-se pensamento crítico e negativo em relação ao estado das coisas) em um momento corpóreo e pulsional, é lição de Nietzsche. Ou seja, o filósofo anti-compassivo por excelência, para quem a compaixão era sinal de fraqueza (Zaratustra dizia: "Tanta bondade, tanta fraqueza enxergo eu. Tanta justiça e compaixão, tanta fraqueza." ${ }^{\text {,614 }}$ ), expressão da "moral de escravos", exortava a pensar a partir da dor:

Não somos rãs pensantes, nem aparelhos de objetivação e máquinas registradoras com vísceras congeladas - temos constantemente de parir nossos pensamentos de nossa dor e maternalmente transmitir-lhes tudo o que temos em nós de sangue, coração, fogo, prazer, paixão, tormento, consciência, destino, fatalidade. [...] Somente a grande dor é o último libertador do espírito, como a mestra que ensina a grande suspeita. ${ }^{615}$

\footnotetext{
${ }^{612} P d M$, pp. 257-258. Anos antes, no outro curso sobre filosofia moral oferecido por Adorno, ele diz também: "No mundo como ele é hoje, a compaixão, o sentimento imediato, ao qual gostamos de recorrer [herausreden] face ao horror em torno de nós, não é mais uma categoria moral justamente por causa desse horror. A compaixão é fundada na capacidade de se ver em outros, de perfurar os limites da individuação (Schopenhauer). Na linguagem da psicologia, a compaixão se funda na identificação, e ela é uma faculdade psicológica. Uma postura moral em sentido mais elevado não pode ser um que se faça dependente da contingência da capacidade para a compaixão. Não há nenhuma outra indicação para a vida correta, a não ser a tentativa, com todo o esforço do pensamento, de conhecer as coisas que importam da forma mais não-ideológica possível." PM 1, TWAA.

${ }^{613}$ Ernst Bloch, Tübinger Einleitung in die Philosophie, p. 12.

${ }^{614}$ Friedrich Nietzsche, Assim falou Zaratustra. São Paulo: Companhia das Letras, 2011.

${ }^{615}$ Friedrich Nietzsche, A gaia ciência in: Obras incompletas. São Paulo: Abril Cultural, 1983, p. 191.
} 
Isso vale mesmo para quem não abandona a "moral de escravos" e permanece do lado da moral dos vencidos (que é onde se encontra "toda moral autêntica" ${ }^{616}$, como dizia Améry). Porém, diferenciando-se da "moral de escravos" cristã e em razão da efetivação da liberdade, o calor das paixões, dos sofrimentos e da dor transforma-se em crítica, à qual é inerente, enquanto atividade da cabeça, um momento de frieza. ${ }^{617}$ Como diz o próprio Marx, "a crítica não é a paixão da cabeça, mas a cabeça das paixões"618. Essa passagem ao pensamento diz respeito tanto ao sofrimento e à necessidade própria quanto à compaixão, ao "sentimento de amor", que, como diz Bloch, deve ser "iluminado pelo conhecimento":

[...] é perfeitamente inerente ao ato de pensar, por ser um ato auxiliador, um certo calor. $\mathrm{O}$ calor do próprio querer ajudar, do amor às vítimas, do ódio contra os exploradores. Sim, esses sentimentos põem em movimento a parcialidade [Parteilichkeit], sem a qual nenhum saber verdadeiro aliado ao ato bom é possível em termos socialistas. Porém, o sentimento de amor que não é, ele próprio, iluminado pelo conhecimento, obstrui justamente o ato auxiliador rumo ao qual ele se põe a caminho. Ele satisfaz-se com demasiada facilidade com a sua própria excelência, evaporase numa nova autoconsciência aparentemente ativa. ${ }^{619}$

$\mathrm{Na}$ afirmação de Bloch de que o sentimento de amor que não é "iluminado pelo conhecimento" torna-se danoso ecoa um dito da Fenomenologia do Espírito de Hegel, em que se lê que "devo amar o próximo com inteligência; um amor ininteligente talvez lhe faria mais dano que o ódio." ${ }^{620}$ Ou seja, o movimento é o da passagem aos contrários: o amor compassivo torna-se pior que o ódio, e é em razão do amor que a compaixão deve

\footnotetext{
${ }^{616}$ Assim termina Améry seu ensaio sobre o ressentimento: "Na verdade, os temores de Nietzsche e de Scheler não se justificavam. Nossa moral de escravos não triunfará. Os ressentimentos - que são a fonte afetiva de toda moral autêntica, que foi sempre a moral dos vencidos - têm escassa ou nenhuma chance de obrigar os vencedores a engolir o fel da sua obra má. Nós, as vítimas, devemos 'dar fim' a esse rancor reativo, no sentido em que usávamos essa expressão no campo de concentração: 'matar'. Devemos morrer. Brevemente estaremos mortos. Até lá, pedimos paciência àqueles cuja tranquilidade perturbamos com nosso rancor." Jean Améry, Além do crime e castigo, pp. 131-132.

${ }^{617}$ Em um célebre estudo que articula teoria crítica, moral e pedagogia, Andreas Gruschka investiga a função da frieza para a formação de indivíduos críticos. Cf. A. Gruschka, Bürgerliche Kälte und Pädagogik: Moral in Gesellschaft und Erziehung. Sobre a relação de Adorno e a clínica da frieza de Freud e a crítica à clínica do amor dos neufreudianos Erich Fromm e Karen Horney, ver: Adorno, "A psicanálise revisada" e uma discussão em Bruno Carvalho, Psicanálise e crítica social em Adorno. Dissertação de Mestrado, USP, 2017.

${ }^{618}$ MEW 1, p. 380.

${ }^{619}$ PE, p. 268

${ }^{620}$ Hegel, Fenomenologia do Espirito, p. 296.
} 
se transformar em frieza crítica. ${ }^{621}$ Essa peculiar mediação entre os extremos sintetiza-se na célebre frase da Dialética do Esclarecimento de Adorno e Horkheimer: "as doutrinas sem compaixão são mais misericordiosas que as doutrinas dos lacaios morais da burguesia." ${ }^{, 622} \mathrm{O}$ interesse da teoria crítica está na causa dos sofrimentos, e o sentido epistemológico do sofrimento (em especial na Dialética Negativa $^{623}$ ) é dado pela objetividade do mundo à qual se acessa por meio da dor: afinal, "sofrimento é objetividade que pesa sobre o sujeito". ${ }^{624}$ Esse vínculo entre sofrimento, desejo, pensamento e crítica não é outra coisa senão o próprio cerne da teoria crítica. Ou seja, o sofrimento que, como diz Bloch, não "avança para o conhecimento", estará condenado ao derrotismo, e é somente no "primado da cabeça" que a "ética se fez carne":

E o amor ao homem, na medida em que se concebe claramente como amor aos explorados, na medida em que avança para o conhecimento real, sem dúvida é um agente indispensável no socialismo. Entretanto, se já o sal pode tornar-se insípido, quanto mais o açúcar, e se já os cristãos sentimentais ficam no derrotismo, quanto mais os socialistas sentimentais na traição farisaica. [...] Sem o primado da cabeça até o fim restam apenas os mistérios da dissolução em lugar da solução dos mistérios. Assim, na conclusão ética da filosofia do futuro feuerbachiana estão ausentes tanto a filosofia quanto o futuro; a teoria de Marx, em função da práxis, pôs ambos em funcionamento e a ética finalmente se fez carne. ${ }^{625}$

Se lembrarmos da frase de Che Guevara transformada em clichê de que "hay que endurecerce, pero sin perder la ternura jamás", devemos acrescentar que vale também o contrário: é necessário enternecer-se, mas sem jamais perder a dureza da inteligência. Tanto o "endurecerce" de Guevara quanto o sentido moral da inteligência crítica constituem, portanto, o cerne do sentido de estratégia na luta pela emancipação à qual a teoria crítica deve se filiar. Afinal, como diz o próprio Adorno, toda a problemática da moral desemboca de volta na "questão da política correta"626.

\footnotetext{
${ }^{621} \mathrm{O}$ mesmo vale para a terapia amorosa de Fromm, que por fim torna-se mais danosa ao paciente do que a frieza freudiana, visto que na frieza clínica busca-se atingir as causas do sofrimento, ao passo que na clínica do acolhimento fica-se preso no âmbito fenomênico do sintoma. Cf. Bruno Carvalho, Psicanálise e crítica social em Adorno, cit.

${ }_{622}$ Adorno; Horkheimer, Dialética do Esclarecimento

${ }^{623} \mathrm{Cf}$. Raymond Geuss, Leiden und Erkennen

${ }^{624}$ DN, p. 24.

${ }^{625}$ PE, p. 270

${ }^{626}$ PdM, p. 262.
} 


\section{Bibliografia}

\section{i) Abreviações empregadas:}

DN - ADORNO, Theodor. Dialética Negativa. Rio de Janeiro: Jorge Zahar, 2009.

EiD - ADORNO, Theodor. Einführung in die Dialektik (1958). Suhrkamp: Frankfurt am Main, 2010.

GS - AdORnO, Theodor. Gesammelte Schriften in 20 Bd. Frankfurt am Main: Suhrkamp, 1997.

HGS - HORKHEIMER, Max. Gesammelte Schriften in neunzehn Bänden. Frankfurt a. M.:

Fischer, 1985 - 1996.

MEGA - Karl Marx Friedrich Engels Gesamtausgabe. Dietz Verlag, Berlin

MEW - Marx Engels Werke. Dietz Verlag, Berlin.

MM - AdORno, Theodor. Minima Moralia. Rio de Janeiro: Beco do Azougue, 2008.

PdM - ADORNO, Theodor. Probleme der Moralphilosophie (1963). Suhrkamp: Frankfurt am Main, 2015.

PE - Bloch, Ernst. O Princípio Esperança. Trad.: Nélio Schneider. Rio de Janeiro: Contraponto ; EdUerj, 2005.

PM 1 - ADORNO, Theodor. Probleme der Moralphilosophie (1958/1959). Vorlesungen.

Theodor W. Adorno Archiv, Berlin.

TE - ADORNO, Theodor. Teoria Estética. Lisboa: Edições 70, 2008.

TWAA - Theodor W. Adorno-Archiv

ZLGF - ADORNO, Theodor. Zur Lehre von der Geschichte und von der Freiheit (1964/65). Suhrkamp: Frankfurt am Main, 2006.

\section{ii) Obras de Adorno:}

AdORNO, Theodor W. Gesammelte Schriften in 20 Bd. Frankfurt am Main: Suhrkamp, 1997. . Asthetische Theorie. Frankfurt a.M.: Suhrkamp, 2012. Briefwechsel. Theodor W. Adorno Archiv, Berlin (TWAA). Inédito. Dialética Negativa. Rio de Janeiro: Jorge Zahar, 2009. . Introdução à controvérsia sobre o positivismo na sociologia alemã. in:

Benjamin, Walter et alli. Textos Escolhidos. São Paulo: Abril Cultural, 1975. Text-Kritik, 1992. ."Graecullus". in Frankfurter Adorno Blätter VIII. München: Edition 1992. Frankfurter Adorno Blätter I-VIII. München: Edition Text-Kritik, Azougue, 2008. Minima Moralia. Trad.: Gabriel Cohn. Rio de Janeiro: Beco do . Notas de literatura I. São Paulo: Duas Cidades; Ed. 34, 2003. Palavras e sinais: modelos críticos 2. Petrópolis: Vozes, 1995. Prismas. São Paulo: Ática, 1998. 
Vorlesung über Negative Dialektik (1965/66). Suhrkamp: Frankfurt am

Main, 2007. Ästhetik (1958/59). Suhrkamp: Frankfurt am Main, 2009.

2010. Einführung in die Dialektik (1958). Suhrkamp: Frankfurt am Main, . Introdução à Sociologia (1968). São Paulo: Editora Unesp, 2008. Ensaios sobre psicologia social e psicanálise. São Paulo: Ed. Unesp, 2015.

Main, 1995. Kants Kritik der reinen Vernunft (1959). Suhrkamp: Frankfurt am

Ed. Unesp, 2010 Kierkegaard: construção do estético. Trad.: Álvaro Valls. São Paulo: 2008. Ontologie und Dialektik (1960/61). Suhrkamp: Frankfurt am Main, Para a metacrítica da teoria do conhecimento São Paulo: Ed. Unesp,

2007.

Main, 1973. Philosophische Terminologie: Zur Einleitung. Suhrkamp: Frankfurt am Main, 2015. Probleme der Moralphilosophie (1963). Suhrkamp: Frankfurt am Teoria Estética. Lisboa: Edições 70, 2008. Três estudos sobre Hegel. São Paulo: Ed. Unesp, 2013. . Vorlesungen. Theodor W. Adorno Archiv, Berlin (TWAA). Inédito. Zur Lehre von der Geschichte und von der Freiheit (1964/65).

Suhrkamp: Frankfurt am Main, 2006.

; HORKHEIMER, Max. Briefwechsel 1927-1969. Band II: 1938-1944.

Frankfurt am Main: Surhkamp, 2004.

Towards a new manifesto. London: Verso, 2011. ; SCHOLEM, Gershom. Der liebe Gott wohnt im Detail. Briefwechsel (1939-1969). Frankfurt am Main: Suhrkamp, 2015.

\section{iii) Bibliografia geral:}

AFSHAR, Yasmin. Materialismo sem imagens. Dissertação de mestrado. Universidade de São Paulo, 2018.

Alves JR., Douglas. Dialética da Vertigem: Adorno e a filosofia moral. São Paulo: Escuta, 2005.

AMÉRY, Jean. Jenseints von Schuld und Sühne: Bewältigungsversuche eines Überwältigten. München: Szczesny Verlag, 1966. [Edição brasileira: Além de Crime e Castigo: Tentativas de superação. Rio de Janeiro: Contraponto, 2013. . Jargon der Dialektik in: Merkur, 1967.

ANDERS, Günther. Besuch im Hades: Auschwitz und Breslau 1966 ; nach "Holocaust" 1979. München: Beck, 1996. Wir Eichmannsöhne: offener Brief an Klaus Eichmann. München: Beck, 2002. Hiroshima ist überall. München: Beck, 1995, Die Antiquiertheit des Menschen I. München: Beck, 2010. Die Antiquiertheit des Menschen II. München: Beck, 2013. Die atomare Drohung. München: Beck, 2003. Über Heidegger. München: Beck, 2001. Une interpretation de l'apriori. Recherches philosophiques, volume IV, pp.

$65-80$ 
Pathologie de la liberté: essai sur la non-identification. Recherches

philosophiques, volume VI, pp. 22-54.

Visit beautiful Vietnam: ABC der Aggressionen heute. Köln: Pahl-

Ruggenstein Verlag, 1968.

Mensch ohne Welt. Schriften zur Kunst und Literatur. München: Beck, 1993

AlmeIDA, Jorge Mattos Brito de. Crítica dialética em Theodor Adorno. Música e verdade nos anos 20. Cotia/SP: Ateliê Editorial, 2007.

ARANTES, Paulo. Entrevista com Marcos Barreira e Maurílio Botelho, Revista Sinal de menos n. 11, v. 2, 2015.

. Hegel: a ordem do tempo. São Paulo: Hucitec, 2000.

. Da noite para o dia. In: Coletivo DAR (org.) Dichavando o poder: drogas e

autonomia. São Paulo: Autonomia Literária, 2016.

. Ressentimento da Dialética: Dialética e Experiência intelectual em Hegel

(Antigos Estudos sobre o ABC da Miséria Alemã). São Paulo: Paz e Terra, 1996

. O Novo Tempo do Mundo. São Paulo: Boitempo, 2014.

Tentativa de identificação da ideologia francesa. : uma introdução. Revista

Novos Estudos CEBRAP, No 28, outubro 1990.

BACKHAUS, Hans-Georg. Dialektik der Wertform: Untersuchungen zur Marxschen

Ökonomiekritik. Freiburg: Ça Ira, 1997.

BADIOU, Alain. La dialectique négative d'Adorno. In : Cinq leçons sur le 'cas' Wagner. Paris: Nous, 2010

. L'être et l'événement. Paris: Seuil, 1988.

BAEZA, Nathalia. The normative role of negative affects and bodily experience in Adorno.

Constellations v. 22, n. 3, 2015.

BenHABIB, Seyla. Critique, Norm, and Utopia. New York: Columbia University Press, 1987.

BENJAMIN, Walter. Escritos sobre mito e linguagem. São Paulo: Ed. 34, 2011.

Gesammelte Schriften I-VI. Frankfurt am Main: Suhrkamp. O anjo da história. São Paulo: Autêntica, 2012. Obras escolhidas I-III. São Paulo: Brasiliense.

Origem do Drama Barroco Alemão. São Paulo: Brasiliense, 1984.

BLANK, Javier. Acumulação sem legitimação e o recrudescimento da violência estatal, Disponível em:

https://www.academia.edu/26450797/Acumulação_sem legitimação_e o recrudescimento da violência estatal

Bloch, Ernst. O Princípio Esperança. Trad.: Nélio Schneider. Rio de Janeiro: Contraponto ; EdUerj, 2005.

Philosophische Aufsätze zur objektiven Phantasie. Frankfurt am Main:

Suhrkamp, 1985.

. Tendenz-Latenz-Utopie. Frankfurt am Main: Suhrkamp, 1985

BRECHT, Bertolt. Histórias do sr. Keuner. São Paulo: Ed. 34, 2006.

. Poemas (1913-1956). São Paulo: Ed. 34, 2012.

BUBNER, Rüdiger. Kann Theorie ästhetisch werden? In: Materialien zur ästhetischen Theorie Th. W. Adornos. Frankfurt a.M.: Suhrkamp, 1995. 
CAmilo, Vagner. Drummond: Da Rosa do Povo à Rosa das Trevas. São Paulo: Ateliê Editorial, 2001.

CARValho, Bruno. Psicanálise e crítica social em Adorno. Dissertação de Mestrado, USP, 2016.

CONZE, Werner. "Freiheit" in Koselleck; Conze; Brunner (Org.). Geschichtliche Grundbegriffe: historisches Lexikon zur politisch-sozialen Sprache in Deutschland Stuttgart: Klett Cotta, 1997.

DARDOT, Pierre. LAVAL, Christian. A nova razão do mundo: ensaio sobre a sociedade neoliberal. São Paulo: Boitempo, 2016.

DIETSCHY, Beat et alli. Bloch-Wörterbuch: Leitbegriffe derPhilosophie Ernst Blochs. De Gruyter, 2016.

ESPINOSA, Baruch de. Ética. São Paulo: Autêntica, 2009.

FLECK, Amaro. Da crítica imanente à crítica do sofrimento: a justificação normativa na obra tardia de TheodorW.Adorno.in: ethic@- Florianópolis, v.15, n.1, Jul. 2016.

Theodor W. Adorno, um crítico na era dourada do capitalismo. Tese de Doutorado, UFSC, 2015.

FouCAUlt, Michel. Dits et Écrits III. Paris: Gallimard, 1977.

Freud, Sigmund. O mal-estar na civilização. São Paulo: Penguin ; Companhia das Letras, 2011.

Freyenhagen, Fabian. Living Less Wrongly: Adorno's Practical Philosophy. Cambridge: Cambridge University Press, 2013. What is Orthodox Critical Theory? In: world picture 12, winter 2017.

GaGNEBIN, Jeanne Marie. Uma filosofia moral negativa? Kriterion v. 49, n. 117, Belo Horizonte, 2008.

GEUSS, Raymond. Leiden und Erkennen (bei Adorno). in: HONNETH, Axel (Org.). Dialektik der Freiheit: Frankfurter Adorno-Konferenz 2003. Suhrkamp: Frankfurt am Main, 2005.

Grossmann, Henryk. Das Akkumulations- und Zusammenbruchsgesetz des kapitalistischen Systems. Leipzig, 1929.

GuMBRECHT, Hans Ulrich. Depois de 1945: latência como origem do presente. São Paulo: Unesp, 2014.

HABERMAS, Jürgen. Conhecimento e Interesse. (Trad.: Luiz Repa). São Paulo: Ed. Unesp, 2014.

am Main, 1988. . Der philosophische Dirkurs der Moderne. Suhrkamp: Frankfurt

\begin{tabular}{l}
. Philosophisch-politische Profile. Frankfurt am Main: Suhrkat \\
. Na esteira da tecnocracia. São Paulo: Ed. Unesp, 2014. \\
\hline . A nova obscuridade. São Paulo: Ed. Unesp, 2015. \\
Técnica e ciência como "ideologia". São Paulo: Ed. Unesp, \\
. Textos e contextos. São Paulo: Ed. Unesp, 2014.
\end{tabular}


am Main, 2014.

Theorie und Praxis. Suhrkamp: Frankfurt am Main, 1971.

Verdade e justificação - ensaios filosóficos. São Paulo: Loyola, 1999

Hegel, G. W. F. Ciência da Lógica (excertos). São Paulo: Barcarolla, 2011.

. Ciência da Lógica. Petrópolis: Vozes, 2016.

Fenomenologia do espírito. Petrópolis: Ed. Vozes, 2002.

Enciclopédia das ciências filosóficas em compêndio. São Paulo: Loyola, 1995.

Vorlesungen über die Geschichte der Philosophie III. Frankfurt am Main:

Suhrkamp, 1986.

Wissenschaft der Logik. Frankfurt am Main: Suhrkamp, 2012.

HobSBAwM, Eric. Era dos extremos: o breve século XX. São Paulo: Companhia das Letras, 1995.

HOLLOWAY, John. Change the world without taking the power: the meaning of revolution today. Pluto Press, 2002.

Honneth, Axel (Org.). Dialektik der Freiheit: Frankfurter Adorno-Konferenz 2003.

Suhrkamp: Frankfurt am Main, 2005.

. Die Pointe der Anerkennung: eine Entgegnung auf die Entgegnung. In:

Honneth; Fraser. Umverteilung oder Anerkennung? Eine politisch-philosophische Kontroverse.

Frankfurt a.M.: Suhrkamp, 2003.

Cambridge: Polity, 2014.

Freedom's Right: on the Foundations of Democratic Life.

Pathologien der Vernunft. Frankfurt am Main: Suhrkamp, 2007

"Sociology of Critique or Critical Theory? Luc Boltanski and Axel Honneth

in Conversation with Robin Celikates" in The Spirit of Luc Boltanski. Essays on the "Pragmatic Sociology of Critique. Turner: Anthem Press, 2014

HORKHEIMER, Max. Autoritärer Staat. In: Wirtschaft, Recht und Staat im Nationalsozialismus (Horkheimer/Pollock/Neumann/Kirchheimer/Gurland/Marcuse). Analysen des Instituts für Sozialforschung 1939-1942. Frankfurt am Main: Europäische Verlagsanstalt, 1981.

. Gesammelte Schriften in neunzehn Bänden. Frankfurt a. M.: Fischer, 1985

$-1996$.

no. 3, Paris, 1934.

. Zu Bergsons Metaphysik der Zeit. Zeitschrift für Sozialforschung, vol. 3,

Hyppolite, Jean. Genèse et structure de la Phénoménologie de l'Esprit de Hegel. Paris:

Aubier, 1946.

JAEGGI, Rahel. Kein Einzelner vermag etwas dagegen. In: : HONNETH, Axel (Org.). Dialektik der Freiheit: Frankfurter Adorno-Konferenz 2003. Suhrkamp: Frankfurt am Main, 2005.

. Kritik von Lebensformen. Frankfurt a.M.: Suhrkamp, 2014.

JAMESON, Fredric. O marxismo tardio: Adorno, ou a persistência da dialética. São

Paulo: Boitempo Editorial, 1996.

JONAS, Hans. O princípio responsabilidade: uma ética para a civilização tecnológica. Rio de Janeiro: Contraponto, 2006.

JORDÃO MACHADO, Carlos Eduardo. Um capitulo da história da modernidade estética: debate sobre o expressionismo. São Paulo: Ed. Unesp, 2016. 
KANT, Immanuel. Crítica da razão prática. Petrópolis: Editora Vozes, 2016. . Crítica da razão pura. São Paulo: Nova Cultural, 1999.

. Fundamentação da metafísica dos costumes. São Paulo: Discurso Editorial ;

Barcarolla, 2009.

. Kritik der praktischen Vernunft. Frankfurt am Main: Suhrkamp, 1974.

Metafísica dos Costumes. Petrópolis: Editora Vozes, 2013.

KAUTSKY, Karl. Arthur Schopenhauer (1888). In Die Neue Zeit, 1888, Heft I, p. 66-78 \& Heft II, p. 97-109.

KERVÉGAN, Jean-François. Que faire de Carl Schmitt? Paris: Gallimard, 2011.

KRAHL, Hans-Jürgen. Der politische Widerspruch der kritischen Theorie Adornos.

Disponível em: http://www.krahl-seiten.de/der\%20politische\%20widerspruch.htm . "Diskussion mit Adorno (1967)". Disponível em:

http://www.krahl-briefe.de/diskussion_adorno.html "Fünf Thesen zu Herbert Marcuse als kritischer Theoretiker der

Emanzipation". Disponível em: http://www.krahl-briefe.de

KOSELLECK, Reinhart. Crítica e crise. Rio de Janeiro: Eduerj/Contraponto, 1999 . Estratos do tempo: estudos sobre história (tradução: Markus Hediger).

Rio de Janeiro: Contraponto; PUC-Rio, 2014.

LEBRUN, Gérard. La patience du Concept: Essai sur le Discours hégélien. Paris: Gallimard, 1972.

LESSING, G. E. Laocoonte. São Paulo: Iluminuras, 1998.

LEVI, Primo. É isto um homem? Rio de Janeiro: Rocco, 1988.

LINDNER, Burkhardt; LÜDKE, Martin W. (Orgs.). Materialien zur ästhetischen Theorie Theodor W. Adornos - Konstruktion der Moderne. Suhrkamp: Frankfurt am Main, 1980.

LOUREIRO, Isabel. Herbert Marcuse - anticapitalismo e emancipação. In: Trans/Form/Ação, São Paulo, 28(2), 2006.

LöWENTHAL, Leo. Mitmachen wollte ich nie: ein autobiographisches Gespräch mit Helmut Dubiel. Frankfurt a.M.: Surhkamp, 1980.

LöWY, Michael. Ersnt Bloch \& Theodor Adorno: Lumières du Romantisme. Disponível em:

$\mathrm{http}: / / \mathrm{www}$. marxau21.fr/index.php?option $=$ com_content\&view=article\&id=21:ernstbloch-a-theodor-adorno-lumieres-du-romantisme $\&$ catid=35: adorno-theodor $\&$ Itemid $=59$

Acesso: 28/05/2015

LUKACS, Georg. História e consciência de classe: estudos sobre a dialética marxista. São Paulo: Martins Fontes, 2003. Teoria do Romance. São Paulo: Ed. 34, 2006.

LÜTKEHAUS, Ludger. Schopenhauer - Metaphysischer Pessimismus und "soziale Frage". Bonn: Bouvier, 1980.

; EBELING, Hans (Orgs.). Schopenhauer und Marx: Philosophie des Elends Elend der Philosophie? Königstein: Hain, 1980. 
LYOTARD, Jean-François. Des dispositifs pulsionnels. Paris: Galilée, 1994.

MALlARMÉ, Stéphane. Crise de vers (1897). In: Igitur - Divagations - Un coup de dés. Paris: Gallimard, 2013.

MANN, Thomas. Ensaios. Org: Anatol Rosenfeld. São Paulo: Perspectiva, 1998.

MARCUSE, Herbert. Eros and civilization. A Philosophical Inquiry into Freud. Boston: Beacon Press, 1974 . Hegels Ontologie und die Grundlegung einer Theorie der Geschichtlichkeit. Frankfurt am Main: Vittorio Klostermann Verlag, 1932. . Kultur und Gesellschaft I. Frankfurt am Main: Suhrkamp, 1973. . One-Dimensional Man: Studies in the Ideology of Advanced Industrial

Society. Routledge, 2002.

Routledge, 1941. . Reason and Revolution. Hegel and the Rise of Social Theory. London:

MARX, Karl. O capital: crítica da economia política. São Paulo: Abril Cultural, 1983. . Karl Marx Friedrich Engels Gesamtausgabe. Dietz Verlag, Berlin Marx Engels Werke. Dietz Verlag, Berlin.

MeHRING, Franz. Zurück auf Schopenhauer! in Die Neue Zeit, 27. Jg. 1908/09, Zweiter Band.

Merleau-Ponty, Maurice. As Aventuras da Dialética. São Paulo: Martins Fontes, 2006. La guerre a eu lieu in Oeuvres. Paris: Gallimard, 2010.

MÜLlER-DooHM, Stefan. Adorno - eine Biographie. Frankfurt am Main: Suhrkamp, 2003.

MÜLLER, Tim. Innenansichten des Kalten Krieges. Über ein glückliches Zeitalter. In Zeitschrift für Ideengeschichte 6, 2012.

NiETZSCHE, Friedrich. Aurora. São Paulo: Companhia das Letras, 2004. . Assim falou Zaratustra. São Paulo: Companhia das Letras, 2011. . Sobre verdade e mentira. In: Obras incompletas. São Paulo: Abril, 1974.

OFFE, Claus. The contradictions of the welfare state. London: Hutchinson, 1984.

PoHrT, Wolfgang. "Der Staatsfeind auf dem Lehrstuhl" in Gewalt und Politik: Ausgewählte Reden \& Schriften 1979-1993. Berlin: Tiamat, 2010. . Theorie des Gebrauchswertes. Über die Vergänglichkeit der historischen Voraussetzungen, unter denen allein das Kapital Gebrauchswert setzt. Berlin: Tiamat, 1995.

POLLOCK, Friedrich. "Staatskapitalismus" in Wirtschaft, Recht und Staat im Nationalsozialismus (Horkheimer/Pollock/Neumann/Kirchheimer/Gurland/Marcuse). Analysen des Instituts für Sozialforschung 1939-1942. Frankfurt am Main: Europäische Verlagsanstalt, 1981.

Crise e transformação estrutural do capitalismo: ensaios. (Tradução:

Amaro Fleck e Luiz de Caux). Manuscrito.

Postone, Moishe. Time, Labor, and Social Domination. Cambridge: Cambridge University Press, 1993

PRADO JR., Bento. Auto-reflexão, ou interpretação sem sujeito? Habermas intérprete de Freud. in: Alguns ensaios. São Paulo: Paz e Terra, 2000. 
PuZONE, Vladmir. Capitalismo Perene: reflexões sobre a estabilização do capitalismo a partir de Lukacs e da teoria crítica. Tese de Doutorado, USP.

QuAdfasel, Lars. Adornos Leninismus: Kritische Theorie und das Problem der Avantgarde in Jungle World, 23/05/2013, disponível em: https://jungle.world/artikel/2013/21/adornos-

leninismus

RENAUlt, Emmanuel. A Critical Theory of Social Suffering. In: Critical Horizons, 2011.

ROUSSO, Henri. La dernière catastrophe: l'histoire, le présent, le contemporain. Paris: Gallimard, 2012.

RÖTTGERS, Kurt. "Kritik" in Koselleck; Conze; Brunner (Org.). Geschichtliche Grundbegriffe: historisches Lexikon zur politisch-sozialen Sprache in Deutschland Stuttgart: Klett Cotta, 1997.

SAFATLE, Vladimir. Auto-reflexão ou repetição: Bento Prado Jr. e a critica ao recurso frankfurtiano à psicanálise. Ágora: Estudos em Teoria Psicanalítica, Rio de Janeiro, v. VII, n.2, p. 279-292, 2004.

. Cinismo e falência da critica. São Paulo: Boitempo, 2008.

O circuito dos afetos. São Paulo: Cosac Naify, 2015.

Freud em Frankfurt: a função da psicanálise no pensamento de Theodor

Adorno. In Por que Freud hoje? São Paulo, 2016.

Sobre a gênese psicológica do transcendental: Adorno entre Freud e Kant.

In: Safatle, Vladimir; Manzi, Ronaldo. (Org.). A filosofia após Freud. São Paulo: Humanitas, 2008, p. 45-75.

SARTRE, Jean-Paul. Carnets de la drôle de guerre. Paris: Gallimard, 1995.

L'être et le néant: Essai d'ontologie phénoménologique. Paris: Gallimard, 1943.

Situations, II - Littérature et engagement. Paris: Gallimard, 1948.

Situations, III - Lendemains de guerre. Paris: Gallimard, 1949.

SCHEIBLE, Hartmut. Kritische Ästhetik: Von Kant bis Adorno. Würzburg: Königshausen \& Neumann, 2012.

SCHILLER, Friedrich. A educação estética do homem: numa série de cartas. São Paulo:

Iluminuras, 1989.

SCHMIDT, Alfred. Adornos Spätwerk: Übergang zum Materialismus als Rettung des

Nichtidentischen. In: Emanzipation als Versöhnung. Ljubljana: Verlag Neue Kritik, 2002. . Adorno - ein Philosoph des realen Humanismus. In Hermann

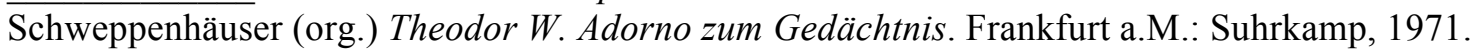
. Drei Studien über Materialismus. Schopenhauer. Horkheimer.

Glücksproblem. München; Wien: Carl Hansen Verlag, 1977.

SchmitT, Carl. Staat, Großraum, Nomos. Arbeiten aus den Jahren 1916-1969. Berlin: Dunckler und Humblot, 1995.

SCHOPENHAUER, Arthur. O mundo como vontade e representação. São Paulo: Ed. Unesp, 2015. 
SCHWEPPENHÄUSER, G. Ethik nach Auschwitz: Adornos negative Moralphilosophie. Wiesbaden: Springer, 1996.

; WiSCHKE M. (Org.). Impuls und Negativität. Ethik und Ästhetik bei Adorno. Hamburg: Argument, 1995.

SocHA, Eduardo. Tempo Musical em Theodor W. Adorno. Tese de Doutorado, USP, 2015.

WELLMER, Albrecht. Metaphysik im Augenblick ihres Sturzes. in: Endspiele: Die unversöhnliche Moderne. Essays und Vorträge. Frankfurt am Main: Suhrkamp, 1999.

WIGGERSHAUS, Rolf A Escola de Frankfurt: história, desenvolvimento teórico, significação política. Lisboa: Difel, 2002.

ZIZEK, Slavoj. Menos que nada: Hegel e a sombra do materialismo dialético. São Paulo: Boitempo, 2012.

(org.). Um mapa da ideologia. Rio de Janeiro: Contraponto, 1994. 